En la piel de la latexgrafía:

una propuesta creativa para la gráfica actual
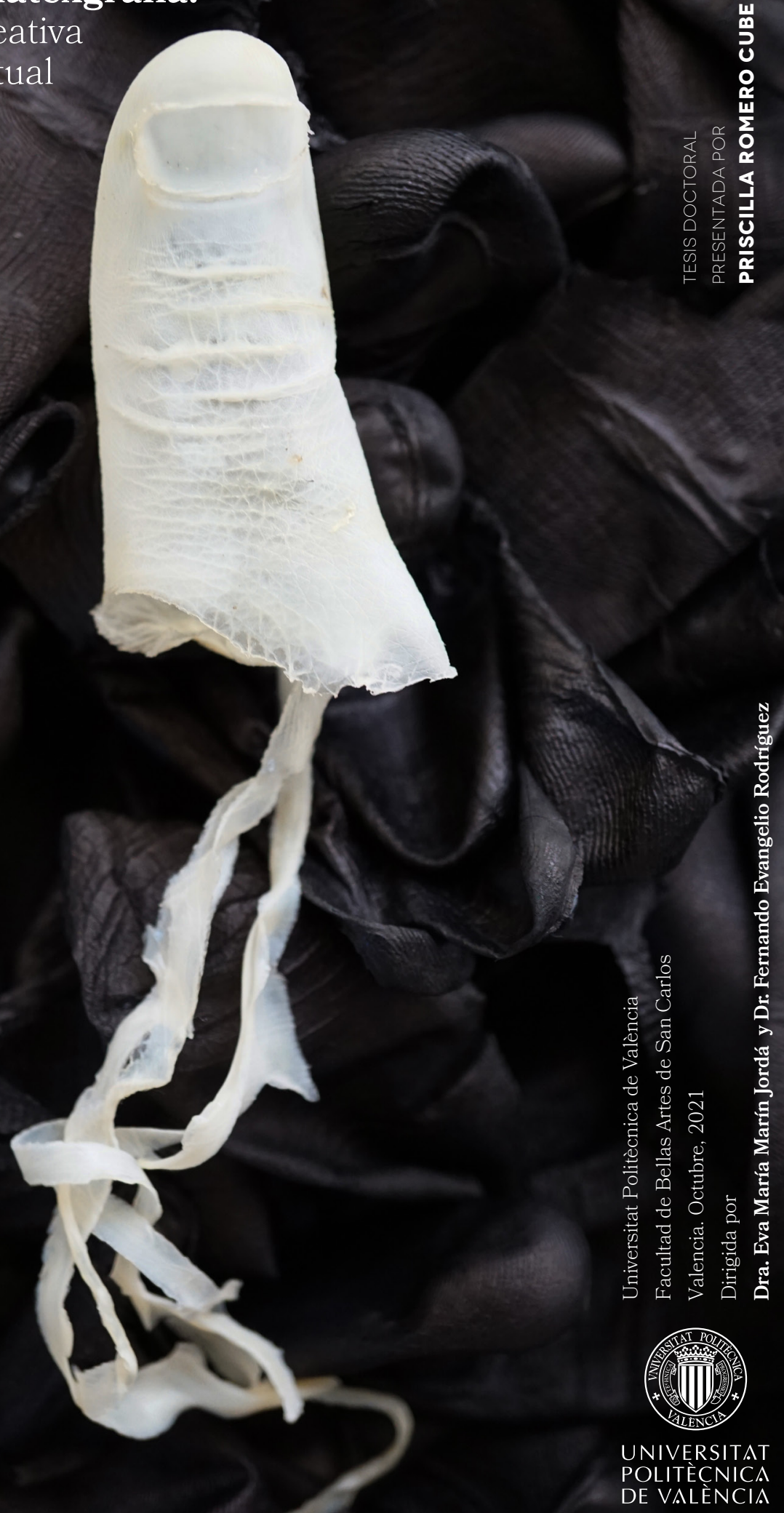
shos

$48=7.20 \% 49$

$2 \times 35$

ne are
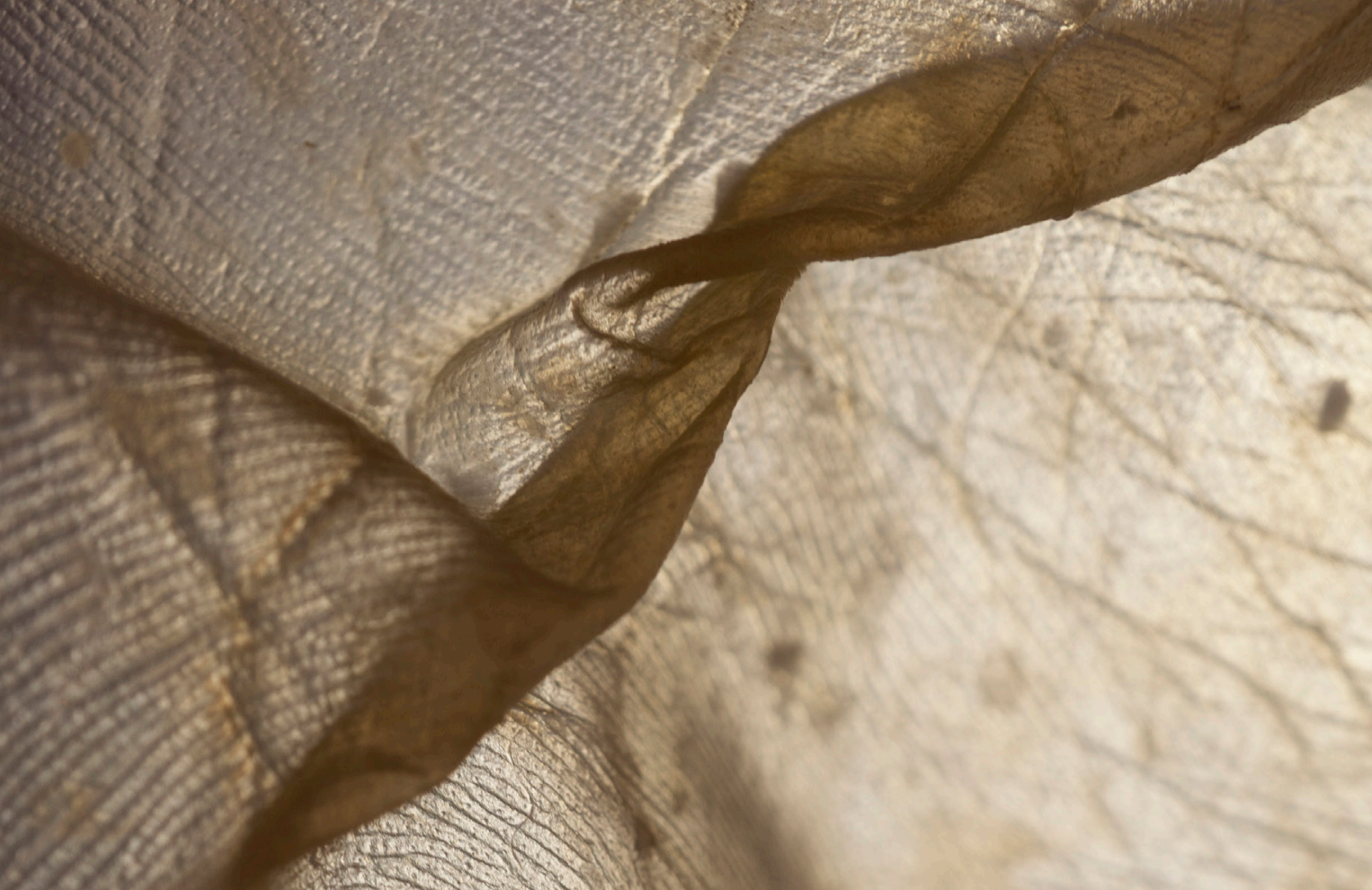

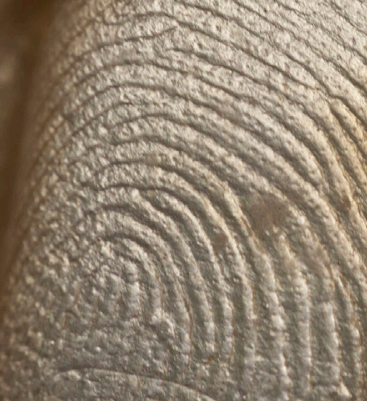

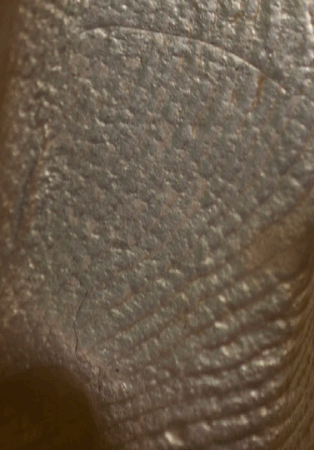

Diseño y Maquetación:

Adriana Bonilla Salas

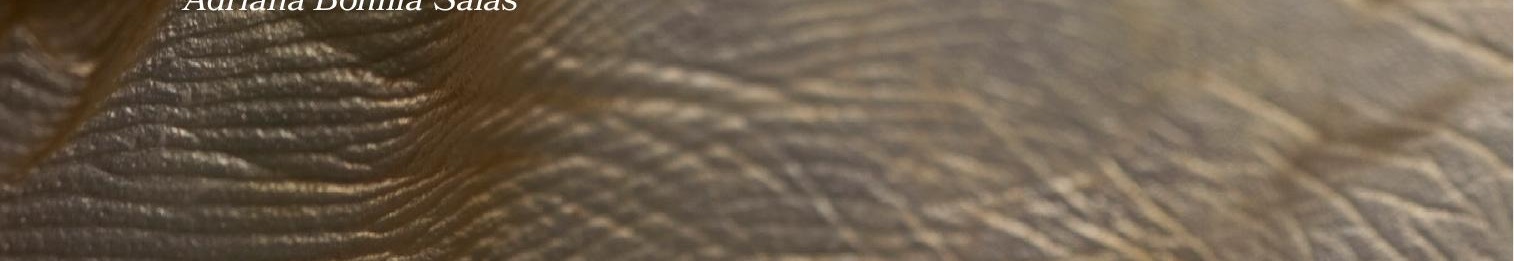


UNIVERSITAT

POLITĖCNICA

DE VALĖNCIA

\section{En la piel de la latexgrafía: una propuesta creativa para la gráfica actual}

\section{TESIS DOCTORAL \\ PRESENTADA POR}

\section{PRISCILLA ROMERO CUBERO}

\section{Dirigida por}

Dra. Eva María Marín Jordá y Dr. Fernando Evangelio Rodríguez

Universitat Politècnica de València

Facultad de Bellas Artes de San Carlos

Valencia. Octubre, 2021 



\section{RESUMEN}

La presente tesis lleva por título En la piel de la latexórafía: una propuesta creativa para la gráfica actual. Investigación en la que se reúnen los aportes diferenciales de la latexgrafía como técnica inédita de grabado y estampación en el campo de la gráfica expandida en el arte contemporáneo. Partimos de la creación artística en relación a la noción del cuerpo, y propiamente de la piel como frontera simbólica entre nuestro ser y el mundo; superficie en cuya huella se registra la memoria gráfica de nuestra existencia e identidad, la misma que gracias a la implementación de nuestra técnica, podemos transmutar en material expresivo, en el marco de un proceso creativo colaborativo entre el público y nosotros.

En una primera parte elaboramos una introducción a la técnica de la latexgrafía, su sentido y práctica, contemplando los conceptos más relevantes y la sistematización del proceso a través de la identificación, descripción y justificación de sus variables. Posteriormente estudiamos los antecedentes y ejes teórico-prácticos de los discursos de la gráfica expandida, con los cuales nos identificamos, para finalmente enumerar los aportes diferenciales, que, desde la latexgrafía, hacemos al ámbito artístico actual. En una segunda parte hacemos una aproximación a las reflexiones poéticas que desde la práctica latexgráfica hemos tejido alrededor de los conceptos del cuerpo, su imagen y las metáforas de la piel, desde una perspectiva interdisciplinar conjugando tanto los aportes de los referentes artísticos como las aproximaciones que desde la filosofía, sociología, antropología y medicina se dan a los conceptos en cuestión, desde mediados del siglo XX a nuestros días en occidente.

Finalmente, la tercera parte la dedicamos a la investigación artística comprendida en el corpus de obra propia, donde presentamos los resultados obtenidos a partir del proyecto Embodied Memory, exposición individual conceptualizada y ejecutada en el marco de esta tesis, así como los últimos avances alcanzados en relación a la latexgrafía, en las piezas desarrolladas en el transcurso del año 2021.

\section{PALABRAS CLAVE:}

Latexgrafía, gráfica contemporánea, cuerpo, piel, fragmento, huella, memoria. 


\section{RESUM}

La present tesi porta per títol En la pell de la latexǵrafía: una proposta creativa per a la ǵràfica actual. Investigació en la qual es reuneixen les aportacions diferencials de la latexgrafía com a tècnica inèdita de gravat i estampació en el camp de la gràfica expandida en l'art contemporani. Partim de la creació artística en relació a la noció del cos, i pròpiament de la pell com a frontera simbòlica entre el nostre ésser i el món; superfície en la petjada de la qual es registra la memòria gràfica de la nostra existència i identitat, la mateixa que gràcies a la implementació de la nostra tècnica, podem transmutar en material expressiu, en el marc d'un procés creatiu colllaboratiu entre el públic i nosaltres.

En una primera part elaborem una introducció a la tècnica de la latexgrafía, el seu sentit i pràctica, contemplant els conceptes més rellevants i la sistematització del procés a través de la identificació, descripció i justificació de les seues variables. Posteriorment estudiem els antecedents i eixos teoricopràctics dels discursos de la gràfica expandida, amb els quals ens identifiquem, per a finalment enumerar les aportacions diferencials, que, des de la latexgrafía, fem a l'àmbit artístic actual. En una segona part fem una aproximació a les reflexions poètiques que des de la pràctica latexgráfica hem teixit al voltant dels conceptes del cos, la seua imatge i les metàfores de la pell, des d'una perspectiva interdisciplinària conjugant tant les aportacions dels referents artístics com les aproximacions que des de la filosofia, sociologia, antropologia i medicina es donen als conceptes en qüestió, des de mitjan segle XX als nostres dies en occident.

Finalment, la tercera part la dediquem a la investigació artística compresa en el corpus d'obra pròpia, on presentem els resultats obtinguts a partir del projecte Embodied Memory, exposició individual conceptualitzada i executada en el marc d'aquesta tesi, així com els últims avanços aconseguits en relació a la latexgrafía, en les peces desenvolupades en el transcurs de l'any 2021.

\section{PARAULES CLAU}

Latexgrafía, gràfica contemporània, cos, pell, fragment, petjada, memoria. 


\section{ABSTRACT}

This thesis is entitled In the skin of latexgraphy: a creative proposal for current graphics. Research that brings together the differential contributions of latexgraphy as a unique printmaking technique in the field of expanded graphics in contemporary art. We start from the artistic creation in relation to the notion of the body, and properly of the skin as a symbolic border between our being and the world; surface in whose imprint the graphic memory of our existence and identity is recorded, the same that thanks to the implementation of our technique, we can transmute into an expressive material, within the framework of a collaborative creative process between the public and us.

In the first part, we elaborate an introduction to the technique of latexgraphy, its meaning and practice, contemplating the most relevant concepts and the systematization of the process through the identification, description and justification of its variables. Later we study the antecedents and theoretical-practical axes of the discourses of expanded graphics, with which we identify our research, to finally list the differential contributions that, from latexgraphy, we make to the current artistic field.

In a second part we make an approach to the poetic reflections that from latexgraphic practice we have woven around the concepts of the body, its image and the metaphors of the skin, from an interdisciplinary perspective combining both the contributions of artistic references and the approaches that from philosophy, sociology, anthropology and medicine are given to the concepts in question, from the mid-twentieth century to the present day in the West.

Finally, the third part is dedicated to the artistic research included in the corpus of own work, where we present the results obtained from the Embodied Memory project, an individual exhibition conceptualized and executed within the framework of this thesis, as well as the latest advances made in relation to latexgraphy, in the pieces developed during the year 2021.

\section{KEYWORDS:}

Latexgraphy, contemporary printmaking, body, skin, fragment, trace, memory. 


\section{ÍNDICE}

INTRODUCCIÓN

MOTIVACIÓN

HIPÓTESIS

OBJETIVOS

METODOLOGÍA

16

ESTRUCTURA DE LA INVESTIGACIÓN

19

ESTADO DE LA CUESTIÓN

\section{PRIMERA PARTE}

1. LATEXgRAFÍA, SENTIDO Y PRÁCTICA 33

1.1. PRINCIPALES CONCEPTOS DE LA TÉCNICA LATEXGRÁFICA

1.1.1. Matriz primigenia

1.1.2. Matriz latexgráfica

1.1.3. Huella latexgráfica

1.2. SISTEMATIZACIÓN Y VARIABLES DEL PROCESO TÉCNICO

1.2.1. Variables del molde

1.2.2. Variables de la matriz latexgráfica

1.2.3. Variables de la tinta y el entintado

1.2.4. Variables del soporte e impresión

1.3. LATEXGRAFÍA Y GRÁFICA EXPANDIDA

1.3.1. Tras las huellas de la expansión gráfica

1.3.2. Desarticulando el cuerpo de la gráfica 69

1.3.3. El mestizaje del tiempo 74

1.4. APORTES DIFERENCIALES DEL PROCESO LATEXGRÁFICO 78

1.4.1 La transmutación de la matriz y la huella 78

1.4.2 La poética de la materia 80

1.4.3 El proceso como rito $\quad 86$

1.4.4 De la expansión gráfica a la extensión comunitaria 90

1.4.5 Hacia un grabado de aprovechamiento 104 


\section{SEGUNDA PARTE}

2. POÉTICAS deL CUERPO DESDE LA PRÁCTICA LATEXGRÁFICA 111

2.1. EL SENTIDO DE LOS CUERPOS 111

2.2. EL SENTIDO DE LAS IMÁGENES 120

2.2.1 Imágenes antropológicas $\quad 120$

2.2.2 Imágenes matriz 121

2.2.3 Imágenes poéticas 123

2.2.4 Imaginación y ficción artística 124

2.3. EL SENTIDO DE LAS PIELES 126

2.3.1 Dimensiones epidérmicas 126

2.3.2 Entre la muda y el desollado 130

2.4 CORPORALIDADES EN (CON)TACTO 141

2.4.1 Huellas del tiempo 142

2.4.2 Fragmentos de memoria 158

\section{TERCERA PARTE}

3. CORPUS DE OBRA 177

3.1. METAFORIZACIÓN DE EMBODIED MEMORY

3.1.1 Digital Archive / Archivo digital 181

3.1.2 Living treasure / Tesoro viviente 188

3.1.3 Splinters of time / Astillas del tiempo y 193

Wood Skins /Pieles madera

3.1.4 Second Skin / Segunda piel 200

3.1.5 Index / Indicios 205

3.1.6 The trace of Midas / El rastro de Midas 212

3.2. NUEVOS TERRITORIOS DE LA GRÁFICA 217

3.2.1 The Fold I / El pliegue I 217

3.2.2 Imago / Imago 222

CONCLUSIONES 228

FUENTES REFERENCIALES _ 239 


\section{INTRODUCCIÓN}

MOTIVACIÓN

¿Cómo escribir con palabras lo que se piensa y se hace con imágenes? Sin duda, amerita un esfuerzo para tomar la distancia justa que nos permita desdoblarnos - aunque de forma temporal- en la piel del otro y así darle voz al lenguaje que encarna su imagen para re-conocernos en él. Este esfuerzo reflexivo, es el motor del proceso creativo, la necesidad intrínseca que germina el acto de creación. Pero, ¿Necesidad de qué? Quizá, la de transmitir una idea artística, la de estimular una reacción empática ante determinada situación, o el simple hecho de construir un imaginario colectivo que nos muestre una percepción distinta de la realidad que íntimamente experimentamos en la cotidianidad.

Movidos por esta necesidad, surgen las ideas creativas, mediante las cuales se articula nuestro discurso, entretejiendo la experimentación técnica, el estudio teórico y las referencias conceptuales, para materializar las metáforas, dotar de significado la experiencia vivencial y propiciar una relación participativa con el público, la imagen y el espacio. Sin embargo, para que estas experiencias se den de una forma fluida y genuina, tiene que haber un impulso suficientemente fuerte que dote de sentido vital a nuestro quehacer. Tal y como lo afirmó Viktor Frankl (2019), "quien tiene un porqué encuentra un cómo”. A continuación, haremos un breve recorrido por esas vertientes que gestaron el porqué y el cómo, para luego comprender el para qué de la presente tesis.

No es secreto para nadie que cuando un autor habla de un tema específico es porque lo ha vivido de forma cercana; tan cercana en este caso, como en el cuerpo propio. Mudar de piel, es, por tanto, un ritual de sacrificio y redención para aceptar nuestra imagen y emprender un vuelo hacia la resiliencia, propulsado por las corrientes del arte. Pero esta muda no es indolora, puesto que metafóricamente implica renacer después de haberse parido a uno mismo, arrancando de raíz los viejos paradigmas que lo subyugaban a determinados cánones de belleza corporal. Mediante 
este proceso cuestionamos los dogmas a través de la incertidumbre, y la realidad, mediante la ficción. Pero, para lograrlo es preciso hacer uso de una herramienta indispensable: la imaginación.

Hoy, más que nunca, imaginar es un acto de resistencia para reflexionar a la luz de los universos simbólicos establecidos, en las convenciones socioculturales e históricas que enmarcan las prácticas y discursos artísticos, en donde se expresan las dimensiones estéticas, políticas, religiosas y económicas que rigen el paradigma de la imagen corporal en occidente. Imaginar, nos permite confrontar críticamente los estereotipos y roles de poder que posicionan al ser humano y su relación con el mundo, en términos de oposición y exclusión. Finalmente, imaginar la posibilidad de desacralizar, emancipar y descolonizar el cuerpo oculto, para vivir en comunidad, respetando el valor de la diversidad como parte inherente de nuestra condición humana.

El rito artístico plantea un proceso de desdoblamiento del "otro" para reconocernos en él. En este proceso se deconstruye el imaginario simbólico que normativiza al cuerpo propio, su apariencia e identidad. Pero, ¿Qué parte del cuerpo es la que encarna nuestra imagen? ¿Cuál es el límite físico y simbólico entre el cuerpo y el mundo?; la respuesta es la piel. El órgano más grande del cuerpo posee múltiples funciones vitales, siendo la percepción una de ellas, a través de la cual estamos encarnados con el mundo mediante la experiencia háptica. La piel también se comporta como una frontera simbólica, dado que en su superficie se registran las marcas de identidad, las huellas dactilares; el paso del tiempo, las cicatrices y el color. Por lo que, desde nuestro enfoque, la consideramos como el espacio que nos sitúa en una relación de copertenencia e imbricación fenomenológica entre nosotros, el mundo y los otros. En definitiva, es la superficie de inscripción que encarna nuestra memoria corpórea.

Una vez que hemos identificado en la piel, esa zona de sospecha, donde la imagen corpórea se encarna; podemos pasar a la siguiente etapa en donde el sentido del desdoblamiento se hace literal, al imaginar la posibilidad de despellejarse a sí mismo. Pero, para hacerlo, es evidente 
que se debe construir un universo ficcional que nos lo permita, ya que de lo contrario no podríamos sobrevivir al acto siniestro del desollamiento. Es ahora, cuando damos el paso de la imaginación y visualización del rito a su representación material y procesual, a través de la investigación artística, que abre la puerta a un enfoque interdisciplinar desde el cual abordar el problema. En función del rito artístico se orquestan los medios, los materiales y técnicas cargados de significado y potencial comunicativo.

El cómo se conceptualiza y ejecuta este rito, en su fase técnica, constituye el hallazgo primordial de nuestro Trabajo Final del Máster en Producción Artística de la Universitat Politècnica de València, que presentamos en el año 2010. Latexǵrafía, es el término con el que denominamos al proceso gráfico inédito que hemos desarrollado para transmutar la huella de la piel en un material expresivo y versátil. Este proceso nos ha acompañado desde entonces y se incorpora como el eje fundamental dentro de la investigación artística de la presente tesis. Para llegar a dicha sistematización se abordó el problema desde la metodología de la investigación basada en las artes. Inicialmente se tuvo que dar respuesta a varias interrogantes: ¿Cómo se puede simular el acto del despellejamiento sin que tenga secuelas físicas? ¿Cómo podemos obtener una replica de la piel humana duradera, y con la máxima fidelidad de su huella?

La búsqueda a estas respuestas nos condujo a una amplia investigación de medios, materiales y procedimientos no invasivos y amigables tanto con el cuerpo como con el ambiente, a través de la experimentación austera y accesible, para que mediante la economía de los recursos se potencializara el discurso, al maximizar el contenido que emana de los materiales y procesos. La latexgrafía debe su nombre al material, el látex líquido natural, una sustancia que cumple con creces las funciones buscadas, gracias a que se convierte en una segunda piel al catalizarse rápidamente en contacto directo con el cuerpo y otros soportes intermedios.

De este modo, podemos concebir al cuerpo propio como la matriz primigenia a través de la cual se engendra la matriz de látex, la cuál es en sí una impronta directa; capaz de registrarse en múltiples soportes 
tridimensionales y estampar su huella en superficies bidimensionales, permitiendo componer una imagen fragmentaria y cartográfica de la piel, que como demuestra esta investigación tiene infinitas posibilidades expresivas y discursivas.

En el marco de este estudio resultó indispensable que, el proceso anteriormente descrito, se concretara en la producción y conceptualización de un corpus de obra propia, emplazada en un contexto de acción y proyección pública, para poder hablar con más propiedad del impacto y los aportes diferenciales del lenguaje latexgráfico, en términos del discurso artístico contemporáneo. Hasta esta fase, la investigación tenía alcances técnicos inéditos que respondían a los vectores emocionales e indagaciones conceptuales que motivaron su hallazgo y que impulsaron la producción de obras iniciales; pero fue necesario que las imágenes encarnaran la memoria de un contexto concreto, que nos permitiera explorar tanto los principios técnicos como sus derivas poéticas, así como su imbricación teórico-conceptual dentro del tejido sociocultural en cuestión.

Siguiendo la tónica del porqué y del cómo, ahora es pertinente describir el para qué, siendo esta fase la que conjuga las anteriores y respalda la presente tesis. Dentro de las actividades específicas requeridas en el marco del programa de doctorado, se participó en distintos eventos artísticos que fueron abriendo camino para poder concretar el proyecto Embodied Memory (Memoria Encarnada), una exposición individual que se llevó a cabo del 7 de noviembre del 2019, al 19 de enero del 2020, en el Museo de Arte Moderno de Bydgoszcz (MOB), Polonia; a razón del premio otorgado por la Trienal Internacional de Grabado de Cracovia. Ante dicha oportunidad, se planteó desde el primer momento que nuestra investigación se concretaría como una instalación, en donde la aprensión y significación simbólica del valor in situ sería inherente a todo el proceso, para hacer partícipes a todos sus agentes y conjugar la memoria sociocultural e histórica del espacio con la piel de los sujetos que la habitan. Esta muestra resultó ser una plataforma imprescindible de divulgación, y las obras ahí expuestas han podido itinerar en otros 
espacios internacionales y servir de punto de partida para nuestra producción más reciente.

Tanto la conceptualización como el estudio teórico y el desarrollo procesual que conforman nuestro corpus de imágenes, son caras de un mismo prisma que giran en torno al desarrollo inédito de la latexgrafía y las poéticas del cuerpo-piel que desde ella se tejen, la correspondencia con los discursos artísticos en torno a la gráfica contemporánea y su expansión, hibridación, mestizaje y no especificidad, así como su imbricación con la realidad histórica y sociocultural del espacio en el que se llevan a cabo. Comprendemos que cada fuente en sí misma es un caudal de información, pero al confluir con las demás, cobran sentido y dotan de significado a nuestra experiencia vivencial y artística.

\section{HIPÓTESIS}

La idea en la que se sustenta nuestra investigación plantea que la percepción y representación del cuerpo propio, implica reconocerse en el otro, aprenderlo como semejante y coexistir en la inherente diversidad de la condición humana, en donde el cuerpo es el médium para experimentar el mundo y su piel el nexo que nos une. En su desarrollo, partimos del concepto de la memoria corpórea encarnada en la piel, que, al desdoblarse y transferir su huella, mediante el proceso inédito de la latexgrafía, deviene en material expresivo.

El cuerpo propio se constituye como matriz primigenia, en cuya superficie epidérmica se registra el rastro gráfico de la existencia, que, al replicarse, expande la memoria encriptada en sus texturas, materializando el rastro y dejando intacto la integridad física de la persona. En esta construcción del imaginario humano, las relaciones diferenciales que nos dividen a razón de parentesco, etnia, religión, género, sexo, nacionalidad o política quedan democráticamente entretejidas en la epidermis anónima; donde la huella del tiempo es la que prevalece en la imagen, que hace de documento testimonial del contacto y el encuentro mutuo de nuestro ser-en-el-mundo. 


\section{OBJETIVO GENERAL}

Demostrar la pertinencia, eficacia y adecuación de la técnica de la latexgrafía en el marco de la investigacióm artística relacionada con la expresión corporal, a través de la impronta de la piel y del registro de la memoria, mediante las huellas dejadas en la materia a lo largo del tiempo. A través de la sistematización técnica que nos permita identificar los aportes diferenciales a la gráfica actual y los alcances discursivos en el marco de un corpus de obra propia que se relacione dialécticamente con el proceso y los ejes teórico conceptuales del ámbito artístico contemporáneo.

\section{OBJETIVOS ESPECÍFICOS}

- Identificar y justificar los aportes diferenciales de la latexgrafía como medio inédito de grabado y estampación al campo de la gráfica contemporánea, mediante la imbricación de sus alcances técnicos y discursivos.

- Establecer y acotar un marco teórico conceptual en torno a la relación dialéctica entre la imagen, el sentido del cuerpo y las metáforas de la piel, que desde la práctica de la latexgrafía se desarrollan.

- Analizar los recursos estéticos de la huella, el fragmento y la memoria en concordancia con el desarrollo e implementación de la latexgrafía, en relación con los referentes artísticos que trabajan estas temáticas conjugando las prácticas del arte corporal y la gráfica expandida, desde mediados del siglo XX a nuestros días.

- Trazar una cartografía del corpus de obra realizado en el marco de la presente tesis, que nos sirva de objeto teórico para reflexionar en torno a la conceptualización y materialización de las metáforas visuales en el proceso creativo. 


\section{METOdOLOGÍA}

La presente tesis se plantea desde la perspectiva de la Investiǵación basada en las Artes (IBA) (Arts-based researh -ABR), abordada a través de un amplio campo de conocimiento, entre los que destacamos los estudios claves de autores como Sullivan (2004) en Art Practice as Research Inquiry the Visual Arts, Hernández, Pérez López y Gómez Muntané (2006) en Bases para un debate sobre investigación artística, Borgdorff (2012) en The conflict of the faculties. Perspectives on artistic research and academia, y Mínguez García (2014) en "La generación de conocimiento en la creación artística y su orientación en el ámbito universitario a nivel de posgrado". En consonancia con este marco conceptual, comprendemos que la investigación artística se basa en la reflexión desde la acción, conjugando tanto su dimensión conceptual y discursiva como su materialización formal, en un proceso de retroalimentación continua. La acción se lleva a cabo en el espacio de trabajo del artista, así como en su participación activa en el contexto sociocultural e histórico.

En suma, es un proceso creador de contenido y generador de pensamiento, desde el cuál se establecen interrelaciones y correspondencias con otros ámbitos del conocimiento, como sucede en nuestro caso con la teoría del arte y las nociones de cuerpo propuestas desde la filosofía, sociología, antropología y medicina. En torno a esta indagación interdisciplinar, se fortalece nuestro discurso, al integrar fenomenológicamente los contenidos al corpus de obra. El proceso creativo a través del cual desarrollamos la técnica de la latexgrafía ha sido llevado a cabo rigurosamente con un método experimental, en cuanto al conocimiento profundo de los materiales y su comportamiento ligado a los resultados que se fueron obteniendo, documentado y sistematizando en una bitácora de trabajo.

Conforme se avanzó en la exploración se fueron mejorando los registros, hasta llegar al procedimiento óptimo con el que hoy contamos. Ese trabajo se inició en el marco de nuestro TFM Romero Cubero (2010) Cartoǵrafías 
del imaǵo. Latexǵrafía. Proceso inédito de experimentación y aportación a la poética del cuerpo, permitiéndonos refinar los resultados, ampliar el campo experimental y reforzar sus componentes teóricos para crear el corpus de obra del proyecto Embodied Memory y las producciones subsiguientes en la presente tesis.

La pregunta generadora fue la siguiente: ¿Cómo replicar la huella de la piel humana con el máximo nivel de fidelidad y el mínimo impacto físico?; de esta interrogante se desplegaron una serie de criterios para la evaluación de la efectividad del registro según cada tipo de variable (molde, matriz, tinta, soporte, entintado e impresión) y sub-variables, dentro del proceso de experimentación. En términos generales, este estudio buscaba establecer un método de registro y estampado que hiciera posible transferir la huella de la piel y su memoria gráfica en un soporte externo, que, a su vez, pudiera ser tanto impronta como matriz, para reproducir dichas marcas corporales con la menor interferencia posible y con medios, herramientas y técnicas no tóxicos, simples y de fácil acceso.

A lo largo de este proceso creativo se recopilaron y analizaron los datos exhaustivamente, para finalmente concluir que el material óptimo es el látex líquido natural, y sistematizar los pasos y procesos intermedios que nos permitieron obtener nuestras primeras improntas producidas íntegramente a través de la latexgrafía.

Paralelamente hemos desarrollado un imprescindible trabajo de campo, en donde se establecen encuentros directos con el público en eventos de formación y divulgación profesional, como ferias de arte, conferencias, concursos, talleres, portafolios abiertos y exposiciones, que nos han facilitado la actualización de contenidos, compartir los aciertos y confrontar colaborativamente los desafíos, en retribución continua a lo largo de la investigación. En estos espacios es donde hemos realizado las jornadas de registro masivo de huellas implementado la técnica de la latexgrafía, en el marco de talleres educativos, en los cuales compartimos con la audiencia los principales contenidos teórico-prácticos de nuestro estudio y les invitamos a donar su huella voluntariamente. 
Conjuntamente al desarrollo técnico de la latexgrafía hemos construido una panorámica de los ejes teóricos que giran en torno a la experiencia del ser corporal en el mundo, su imagen y memoria encarnada en la huella de la piel, que nos ha permitido identificar los enfoques afines a nuestra investigación. Para poder determinar las principales fuentes hemos partido de las palabras clave de nuestra investigación como criterios para filtrar, identificar y recopilar los datos que luego se analizaron a lo largo de la investigación. Como fruto de esta recopilación de fuentes contamos con referencias tanto primarias como secundarias, que abordan el problema en cuestión; comprendidas en: tesis doctorales, monografías, artículos especializados, catálogos, conferencias, recursos audiovisuales, recursos fímicos y páginas web, así como la retroalimentación verbal durante los talleres impartidos para la recolección de huellas en los diferentes contextos.

Nuestros procesos creativos no se constriñen a una estructura lineal predeterminada, sino, por el contrario, cambian y se amoldan a las circunstancias, dependiendo de la necesidad y la experiencia participativa dentro el contexto, el ámbito de conocimiento y el manejo de las técnicas. Por tanto, las ideas son inseparables del medio de expresión, tal y como lo sostiene Deleuze (1987) en su conferencia ¿Qué es el acto de creación? ${ }^{1}$ Desde este enfoque, el acto creativo puede emerger y propagarse desde múltiples fuentes sin que exista un orden jerárquico; por ejemplo los estímulos pueden venir de las cualidades físicas y poéticas de la materia, o de una experiencia vivencial de la artista en el contexto social; tan sólo por nombrar los más comunes en nuestro estudio; lo cierto es que en uno u otro caso, siempre hay un impulso que conecta los demás nodos entre sí, y ese impulso es la idea que surge por la necesidad intrínseca del propio proceso creativo.

\footnotetext{
${ }^{1}$ Esta conferencia fue impartida en La Escuela Superior de Oficios de Imagen y Sonido de París en 1987, y se encuentra recogida el video publicado por Los dependientes. ( 2 de julio del 2013).
} 
Desde la investigación basada en las artes, pretendemos validar el proceso técnico como el campo de aprendizaje continuo, lugar donde identificamos nuevos problemas visuales y damos forma a las ideas mediante la conceptualización y materialización de metáforas. A través del pensamiento metafórico generamos distintos modelos para experimentar la realidad de las cosas más cotidianas, en nuestro caso, la memoria gráfica grabada en la huella de la piel. La metaforicidad nos ayuda a crear analogías entre la realidad que conocemos y el significado simbólico que hemos construido en torno a ella. Así, el arte, tiene el potencial de ir más allá de quien lo generó y establecer un juego dialéctico con los universos simbólicos a través de las metáforas visuales plasmadas en las imágenes.

En consecuencia, abordamos el análisis del corpus de obra, partiendo de la revisión de los bocetos y su evolución en el tiempo hasta decantar en el estado actual de las imágenes, dado que algunas obras siguen en proceso de creación. Para ello hemos seleccionado una serie de trabajos, que por sus características representan un punto de inflexión dentro de la investigación para enfatizar la capacidad del objeto artístico para generar conocimiento y pensamiento, desde la inmersión del proceso in situ en el seno social, lo que amplia el campo de lectura de la imagen a sus múltiples dimensiones. Para este proceso, destacaremos el contenido que emana de las diferentes capas de realización de la imagen dentro del proceso creativo.

\section{ESTRUCTURA DE LA INVESTIGACIÓN}

Los contenidos de la presente investigación se articulan en tres apartados con un hilo conductor común: la latexgrafía. En el primer capítulo: Latexǵrafía, sentido y práctica, elaboramos una aproximación técnica en la que se recapitula el proceso creativo de la latexgrafía llevado a cabo en el marco de nuestro estudio, destacando su carácter inédito en el campo del grabado y la estampación múltiple. Partimos de una breve introducción, la definición de los conceptos más relevantes que hemos acuñado y la sistematización del proceso a través de la identificación, 
descripción y justificación de sus variables; para luego relacionar la técnica latexgráfica con los antecedentes y ejes teórico-prácticos del pensamiento contemporáneo en los discursos de la gráfica expandida. Finalmente concluimos este capítulo con la identificación y análisis de los aportes diferenciales, que, desde la latexgrafía, hacemos al ámbito artístico actual, en el que imbricamos tanto su dimensión práctica como conceptual. Para ello planteamos un diálogo crítico con las reflexiones teóricas analizadas anteriormente, así como las realizadas en torno a nuestra investigación artística, publicadas en los artículos académicos del catálogo de Embodied Memory (2019).

En el segundo capítulo: Poéticas del cuerpo desde la práctica latexǵráfica, establecemos y acotamos un marco teórico en torno a los tres ejes discursivos: El sentido de los cuerpos, El sentido de las imágenes y El sentido de las pieles; que desde la práctica de la latexgrafía se tejen al corpus de la presente tesis. Este apartado, resume las múltiples reflexiones que han contribuido a enriquecer el contenido interdisciplinar del proceso latexgráfico. Para ello trazamos puentes que conectan la investigación artística y los distintos ámbitos del conocimiento; gracias a los cuales hemos construido y modelado nuestro enfoque, como lo son: las perspectivas filosóficas, fenomenológicas, sociológicas, antropológicas y médicas, en torno a la imagen corpórea y la memoria encarnada en la piel, en el contexto occidental desde mediados del siglo XX hasta nuestros días.

Dentro de este apartado, planteamos un breve análisis de los ejes conceptuales que mejor definen la identidad plástica de nuestro trabajo, como lo son: la huella, el tiempo, el fragmento y la memoria, a la luz de los aportes que los referentes artísticos específicos han realizado en torno a las temáticas en cuestión, puntualizando y justificando los aspectos de las obras con las que nos identificamos. En este estudio correlacional, destacamos los nexos indisolubles entre los conceptos a partir de las diferentes estrategias plásticas utilizadas por sus autores para vincular la construcción del discurso crítico con la poética visual. 
Finalmente, en el tercer capítulo: Corpus de obra, primeramente, elaboramos una síntesis de la metaforización gráfica del proyecto Embodied Memory, a través de un recorrido por los bocetos, resumiendo las etapas más relevantes de la construcción de las imágenes y el emplazamiento de las mismas en el espacio de exhibición, en el cual se contemplan las variables más importantes del diseño museográfico, a partir de un grupo de trabajos representativos, que nos han servido de objeto teórico para elaborar una lectura apoyada en las imágenes y sus procesos de conceptualización y materialización. En un segundo bloque, damos un paso al frente, al presentar los nuevos proyectos que hemos realizado en el presente año. En este proceso autocrítico, destacamos los principales niveles de contenido inmersos en cada imagen estudiada. 


\section{ESTADO DE LA CUESTIÓN}

En el presente apartado acotamos un breve recorrido por el estado de la gráfica expandida y las prácticas artísticas corporales, que involucran el desarrollo y conceptualización de estrategias técnicas, que han servido de antecedente para la latexgrafía. Consientes de que este medio gráfico tiene particularidades específicas y resultados concretos, que le dan un carácter inédito, ampliaremos esta revisión a las prácticas y procesos de otros creadores e investigadores que han trabajado en torno al registro, transferencia y reproducción de texturas de carácter diverso. Contemplaremos procesos interdisciplinares que, por su coherencia con el contexto y nuestro objeto de estudio, reflexionan en torno a las poéticas matéricas que involucran el contacto corporal por adherencia e impresión directa, para crear experiencias efímeras e improntas tanto bidimensionales como tridimensionales.

A continuación, revisaremos los antecedentes más destacados desde la perspectiva del grabado matérico, propiamente, aquellas tesis doctorales que han problematizado procesos de creación de la matriz y alternativas al soporte:

- Comenzamos con el estudio de Martínez García (2006), El uso de la piel animal como soporte para obra ǵráfica original, en la que el investigador propone una catalogación de las diferentes pieles animales, para suplir el soporte del papel en la obra gráfica. De modo, que procede a sistematizar las diferentes variables técnicas de los procesos de impresión, en según qué tipo de piel, a través de matrices de huecograbado y relieve, estableciendo relaciones comparativas entre las diferentes improntas.

- En esta misma vertiente, encontramos el aporte de Chaves Badilla (2011) en Técnica y didáctica de huecograbado en cuero como materia prima para la elaboración de matrices en técnicas de grabado no tóxico para la facultad de Bellas Artes de la UCR, un meticuloso estudio de las superficies convencionales del grabado al hueco y su impacto en 
el ambiente y la salud, para buscar una salida alternativa y sostenible. El "cuero" como superficie receptora, al humectarse sirve de matriz, incorporando los métodos artesanales del cordobán y guadamecí. En este soporte se pueden realizar toda una serie de texturas y transferir otras matrices tradicionales. Esta técnica de grabado se denomina Coriumgrabado, se imprime convencionalmente sobre papel y ha sido recientemente patentada por su autor.

- Desde el enfoque del grabado, con y a través de moldes, destacamos el estudio de Ruiz Ruiz (2008) en El molde de bloque como matriz. Una mirada personal al relieve en la gráfica contemporánea, a través del cual la artista plantea la construcción de matrices de grabado a partir de resina sintética, conjugando lenguajes escultóricos y gráficos para obtener improntas con carácter volumétrico. Esta técnica de "matriz de bloque" se realiza partiendo del modelado en plastilina como medio receptivo a toda una serie de texturas. Una vez acabada esta etapa, se procede a realizar los moldes y contra moldes, a partir de los cuales se puede imprimir con tinta, en gofrados o con pulpa de papel, tal y como lo realizó Rufino Tamayo en las mundialmente conocidas mixografías.

Ahora bien, a diferencia de las tesis de Martínez García (2006), Chaves Badilla (2011) y Ruiz Ruiz (2008), en las que su aporte recae principalmente en la implementación y sistematización de las variables técnicas, en los siguientes dos casos, además de los componentes técnicos, encontramos una reflexión en torno a las poéticas del cuerpo, materializada en la producción de obra propia que se inserta como hilo conductor a lo largo de la investigación:

- El primer caso corresponde a Kanaan (2011) y su tesis titulada Impressões, acúmulos e rasgoos: procedimentos litoǵráficos e seus desvíos, producción plástica y discursiva donde hilvana los referentes de la fenomenología del cuerpo y la noción de lo informe, con un desarrollo técnico impecable. La artista utiliza el látex natural como soporte receptivo de la estampa litográfica, mediante la cual transfiere texturas naturales, huellas de la piel y de textiles a los pellejos de látex que emulan 
un tejido epidérmico y visceral. Estas improntas tienen carácter objetual y se exponen en el marco de la instalación, el libro arte y el performance.

- El segundo estudio es el valioso aporte de Dyrda (2017) en Interference into the Object. Transgressive Print, un documento coherente con su título, ya que se plantea la trasgresión del concepto de matriz y soporte a través de la intermediación de la piel como superficie receptora y la intervención de objetos como matriz. En una propuesta en la que se conjuga la acción corporal como acto de impresión. El proceso de impresión se registra paralelamente mediante video y fotografía. Todos estos recursos se exhiben en el marco de la instalación, a manera de conjunto.

Además de contemplar investigaciones artísticas documentadas en tesis doctorales, también hemos realizado una revisión de manifestaciones culturales, que a lo largo de la historia han utilizado la piel como superficie de memoria desde y sobre la cual registrar la huella:

- Comenzamos este camino con el arte rupestre, propiamente, la conocida Cueva de las manos, en la Patagonia de Argentina, que cuenta con aproximadamente 9000 años de antigüedad, espacio en el que se documentaron improntas utilizando las manos como matriz y plantilla, para estarcir pigmento e imprimir sus huellas para la posteridad.

- Otro referente importante, son los sellos precolombinos costarricenses que datan entre el 300 a.c al 800 d.c, utilizados en rituales donde se rodaban sobre las pieles de las personas, dejando tras de sí un patrón modular abstracto.

- Desde oriente, traemos a colación la técnica del Gyotaku, la cual se inició a mediados del siglo XIX, cuando los pescadores japoneses decidieron registrar sus mejores ejemplares, a través de la aplicación de pigmentos naturales directamente sobre el cuerpo del pez, y mediante el frotado de esta superficie sobre el papel, obtener una impronta fiel con apariencia tridimensional. 
A partir de la posmodernidad, el arte conceptual tomó fuerza, y con él, las practicas corporales cobraron un auge importante. En congruencia con nuestro posicionamiento, hemos escogido obras diferenciales en las que durante el proceso no se atente contra la integridad física de la persona y prevalezca la impronta directa del cuerpo como soporte y/o matriz:

- A inicios de la primera mitad del siglo pasado se encuentran las obras de Yves Klein, mundialmente conocidas como Antropometrías (1960), donde se conjuga los lenguajes pictóricos con el performance para transformar a las modelos en cuerpos pincel, y registrar la huella de su movimiento sobre el lienzo. Por su parte el artista David Hammons realiza la serie Body prints (1969), utilizando su cuerpo como matriz, a través de una técnica basada en la aplicación de material graso para dejar su impronta sobre el papel, y luego jugar con la humedad para que la huella absorba el polvo de grafito y se torne visible, tal y como se realiza en la ciencia criminalística.

- Entre 1977-1982, la artista Vera Chaves Barcellos, entinta su cuerpo desnudo con pigmento graso y utiliza papel mantequilla para trasferir, mediante el frottage, la huella de su epidermis. Una vez registradas estas improntas negativas de su piel, las fotografía, amplía y reproduce en un formato monumental de fragmentos, conjunto al cual denomina Epidermic Scapes. En 1981, Carlos Leppe en ayuda de su compañero Marcelo Mellado, realizan en el Taller de Artes Visuales de Santiago de Chile, la acción titulada Prueba de Artista, en la que ambos utilizan su piel y plantillas, como soporte para imprimir la palabra "Activo", como símbolo de resistencia al convulso clima político de la dictadura en su momento.

- $\quad$ Adentrados en la década de los 90, destacamos los aportes Kiki Smith en Skins (1992), en la que la artista realiza moldes de su cuerpo, los mismos que son vaciados al positivo en aluminio y multiplicados modularmente hasta conformar una obra mural de retazos corporales en relieve. Por su parte, en 1995, Oscar Muñoz nos plantea Aliento, obra mediante la cual establece un juego conceptual a través de la implementación de la técnica, ya que realiza una serie de espejos que han 
sido previamente fotograbados con imágenes de personas desaparecidas, a las cuales sólo se accede a mirar si el público se acerca lo suficiente para verse reflejado, e inadvertidamente, revelar el retrato oculto con su aliento, gracias a la película sensible a los cambios de temperatura y humedad del soporte.

- A inicios del presente siglo contamos con la acción de Javier Velasco titulada Cutáneo (2001) en la que el utiliza el látex líquido natural para extraer pequeños fragmentos epidérmicos negativos y ampliarlos en la pantalla de un proyector, conforme los iba realizando a la vista del público. De igual manera y siempre desde la utilización de la piel como soporte, Javier Calvo plantea una acción corporal que posteriormente registra en video y fotografía, titulada DIS (2013) en la que por medio de una plantilla deja la impronta del sol sobre su epidermis. Por último y no menos importante, se encuentran los conjuntos escultóricos de Kanaan, tituladas Policuerpos, realizadas a través de la instalación de sus improntas de látex, entre 2011 y 2012, así como la intervención espacial de Dyrda, Brudas (2017) donde convierte una sauna en matriz xilográfica y los cuerpos desnudos en soporte sensible. Una obra que podemos vincular con el trabajo de Thomas Kilpper que gira alrededor del concepto del in situ o site-specific, al apropiarse de la memoria gráfica de las superficies de maderas del mismo lugar donde se hace la instalación.

Estos, y muchos otros autores, serán analizados a lo largo del presente estudio, pero son tan solo una muestra de las múltiples formas en las que la singularidad de la piel puede devenir, tanto en huella como en matriz y soporte, y transgredir los límites de la convención moderna del grabado. Un comportamiento que nos parece propio de las tendencias creativas actuales, pero que su germen se gesta a mediados del siglo pasado, en lo que hoy conocemos como "gráfica expandida" o "gráfica de campo expandido". Para contextualizar este giro histórico, al hilo de nuestro discurso y fundamentar la latexgrafía y sus derivas técnico conceptuales, nos hemos apoyado en lo que consideramos son los documentos más relevantes, dado su contundencia argumentativa e impacto extendido en el tiempo: 
- Primeramente, tenemos los aportes del grupo The New York Graphic Worshop (TNYGW) compuesto por Liliana Porter, José Guillermo Castillo y Luis Camnitzer, siendo este último quien documenta en Texto (1969), los dos manifiestos que apelan a la desarticulación del grabado y la necesidad de abrirse a terrenos interdisciplinares a través del objeto artístico concebido como FANDSO, que apela a la reinvención del artista grabador para que "revele sus propias imágenes", es decir, para que tenga un criterio conceptual más allá del técnico y reflexione críticamente en torno a las prácticas que históricamente se habían venido gestando, para desvincularse de viejos atributos del grabado como arte menor y meramente reproductor, e incurrir en una resignificación de la obra gráfica como arte contemporáneo.

- Por otra parte, contamos con la imprescindible noción de La escultura en el campo expandido, de Rosalind Krauss (1979), quien ha sido una de las fuentes teóricas más citadas a lo largo de los estudios, como precedente de lo que hoy concebimos como la instalación. Lugar polisémico en donde se da el mestizaje, hibridación y no especificidad entre los campos artísticos, que prevalecen en las prácticas contemporáneas. Un texto que repercutiría en todos los ámbitos, y que, en las artes gráficas múltiples, vendría a cuestionar el estatuto de la matriz y la edición multicopia, para darle la categoría del multioriginal.

- En lo que respecta a la obra gráfica y la instalación, además de los dos documentos anteriormente mencionados, y el monográfico de Tala (2009) Printmaking Handbook. Instalations \&ّ Experimental Printmaking, queremos poner en manifiesto la excelente tesis doctoral de Gallardo (2015) La estampa que habita el espacio. Arte múltiple e instalación. Recorriendo los límites de la gráfica contemporánea, en la que la artista presenta una perspectiva poliédrica de las fronteras, cada vez más difusas, de la gráfica actual, a través de un excelso recorrido histórico por las diferentes vertientes y enfoques críticos, hasta decantar en el análisis de un corpus de obra propia que encarna los intereses que motivaron su investigación. 
- Posteriormente, en un contexto más cercano, contamos con las bases que plantea Martínez Moro (2008) en Un ensayo sobre grabado (A principios del siǵlo XXI) mediante el cual trazamos un recorrido histórico para desmitificar y deconstruir el estado actual de la gráfica, y del mismo autor, pero en el marco de la Conferencia Internacional Multidisciplinaria de Grabado, Artistas, Conceptos y Técnicas, conocida por sus siglas en inglés como IMPACT, en cuya décima edición imparte la ponencia titulada Encuentro con el tiempo. Grabado en expansión: espacio y tiempo, un artículo publicado en el 2018, el cual es clave para comprender los antecedentes experimentales y expansivos del grabado, así como los rasgos afines a los discursos contemporáneos del arte, como lo son la temporalidad y el mestizaje.

- En este mismo encuentro internacional, destacamos el aporte de Candiani (2018) quien dirige el grupo de investigación ACE, y plantea el texto Encuentro con otras disciplinas. Acerca de la no-especificidad de las prácticas ǵráficas contemporáneas, en el que propone las desarticulaciones gráficas como alternativa conceptual para comprender las derivas de las distintas categorías que imperan hoy día, entre las que destaca los encuentros entre la impronta corporal y el performance, de la mano con los planteamientos de Garramuño (2015), quien establece el concepto de la no especificidad en de los ámbitos artísticos como identidad de los lenguajes contemporáneos.

- También contamos con dos fuentes generales que engloban varios investigadores en gruposy documentos de investigación. En cuanto al grupo de Investigación dx5 graphic_art_research, adscrito al Departamento de Dibujo de la Universidad de Vigo, realzamos dos documentos, el primero, On Minded Prints. Gráfica Contemporánea de campo expandido (2011) y el segundo, Encuentros de Interacción Gráfica. Originalidad en la cultura de la copia (2012), donde destacamos los enfoques de Mínguez García (2012) en torno a la dimensión fenomenológica de la gráfica contemporánea en la cultura de la copia y Castro Muñiz (2008) en Mapas Invisibles para una gráfica electrónica (de la huella incisa al grabado con luz), en cuanto a la matriz intangible en la época posindustrial. 
- Por otra parte, con respecto a la construcción de una panorámica global del pensamiento crítico en torno a la gráfica actual, hemos consultado los textos de Noyce (2010 y 2013) Critical Mass: printmakinǵ beyond the edge y Printmaking. Off the beaten Track, respectivamente. En esta misma tónica se encuentra el documento recopilatorio titulado Perspectives on Contemporary Printmaking. Critical Writing since 1986, editado por Pelzer-Montada (2018); un libro en el que se reúnen los principales enfoques teórico-críticos alrededor de la gráfica expandida desde el contexto posmoderno hasta nuestros días. En él se recopilan más de treinta artículos académicos, a través de los cuales se discute la genealogía, los debates, los ejes claves y los nuevos desafíos del ámbito gráfico contemporáneo.

En cuanto a la argumentación teórica conceptual de las poéticas del cuerpo que desde la práctica de la latexgrafía hemos desarrollado, contamos con un amplísimo marco referencial, del cual haremos un extracto a continuación, puntualizando los tres ejes principales y los autores más relevantes:

- Con el propósito de esbozar la noción de cuerpo con la cual nos sentimos identificados, hemos partido primeramente del imprescindible libro editado por Hernández-Navarro y Cruz (2017) Cartoǵrafías del cuerpo. La dimensión corporal en el arte contemporáneo, el cual nos sirve de mapa para ubicar las diferentes corrientes discursivas que giran en torno al cuerpo en el arte. Seguidamente elaboramos una búsqueda a través del pensamiento filosófico y sociológico, dentro del cual nos apoyamos en conceptos claves de la sociología del cuerpo, en tanto que constructo teórico dentro del imaginario colectivo, que plantea Le Breton (2018), así como la noción de "el pliegue" extendido a la corporalidad, desde el pensamiento de Deleuze (1989), la dislocación de la forma en el concepto de "lo informe" en Bataille (1985), y "lo abyecto" de Kristeva (2006). 
Por otra parte, se encuentra la perspectiva fenomenológica representada en los aportes de Merleau-Ponty (2010) alrededor de la noción de la encarnación y el quiasmo en relación a nuestro ser en el mundo. Un marco referencial que nos remite a otro autor crucial para nuestro estudio, Pallasmaa (2014) quien plantea una fenomenología de la imagen corpórea en la cultura contemporánea y las distintas dimensiones del cuerpo a través de la experiencia háptica y multisensorial. Es precisamente este último punto, el referente al cuerpo que deviene simbólicamente en su piel, lo que desde el pensamiento de Nancy (2016) se refrenda, en Corpus y 58 indicios sobre el cuerpo.

- Con respecto al sentido de las imágenes partimos de la noción antropológica de Belting (2007) en la que se remite al cuerpo como medio vivo en el que se emplazan las imágenes, para luego remitirnos a la noción de la creación de la imagen a través del cuerpo y la materia, en los conceptos de impresión por adherencia que establece Didi-Huberman (2015) como "imagen matriz" y Brea (2016) como "imagen materia", para categorizar la dimensión intrínseca que poseen las imágenes tangibles con respecto al contenido que emana del proceso y de la poética de la materia. Por último, contamos con la dimensión de la "imagen poética" que propone Pallasmaa (2014) para referirse a la categoría de imágenes propiamente artísticas y su imprescindible papel para fomentar la empatía y la imaginación. Partiendo del concepto de imaginación realizamos un breve análisis según los planteamientos de Scheaffer (2012) que reflexiona alrededor del papel de la ficción lúdica que toman lugar en el arte, desde los cuales se analizan los procesos cognitivos que se involucran en el acto de la imaginación, y cómo estos procesos los relacionamos en el proceso latexgráfico.

- En cuanto al sentido y metáforas de la piel como superficie de memoria, hemos considerado tanto su dimensión biológica como simbólica, apoyándonos en textos referenciales que lo conjugan con el estado del arte, como lo son las tesis doctorales de Martínez Rossi (2008) en La piel como superficie simbólica. Procesos de transculturación en el arte contemporáneo y Amador (2013) en La piel como soporte estético 
del cuerpo. Análisis e interpretación de la piel y el cuerpo en la obra fotoǵráfica de Isabel Muñoz, Rodrigo Petrella y Ricardo Marujo. Así como las dimensiones semánticas, perceptivas, sensoriales y fenomenológicas de la piel en tanto que frontera cultural en Benthien (2002) Skin on the cultural border between self and the world y la perspectiva antropológica de la piel como tejido vivo que nos une a la naturaleza desde las reflexiones de Jablonski (2013) en Skin. A natural history. en nuestro Trabajo Final de Máster: Romero Cubero (2010), en Cartografías del Imagoo. Latexǵrafía: proceso inédito de experimentación y aportación a la poética del cuerpo, en el que trazamos los cimientos técnicos de la latexgrafía, los mismos que continuaron expandiéndose y perfeccionándose hasta llegar a la sistematización y adecuación con la que contamos este documento, y mediante los cuales hemos articulado el andamiaje teórico práctico para la elaboración de un corpus de obra, en donde se toman en consideración los aspectos que hemos descrito a lo largo de este apartado, con el fin de realizar un aporte significativo al campo gráfico interdisciplinar del arte contemporáneo. 


\section{LATEXGRAFÍA, SENTIDO Y PRÁCTICA}

La latexgrafía es un proceso técnico de grabado y estampación desarrollado en el marco de la presente investigación, a través del cual registramos, transferimos y reproducimos la huella de la piel y otras superficies, a partir de moldes que emulan las características formales de este tejido, tales como: translucidez, elasticidad, delgadez, permeabilidad y resistencia. El látex líquido natural es el material que da nombre a la técnica y nos ha permitido desdoblar y transmutar el volumen corporal en un soporte, que puede comportarse como matriz e impronta del cuerpo. Gracias a este procedimiento, la memoria gráfica encarnada en la piel, entendida como el cúmulo de tramas, texturas y marcas de identidad grabadas por el tiempo, se expande y transmuta en diversos materiales y soportes, tanto bidimensionales como tridimensionales, vinculando así, los lenguajes escultóricos y gráficos en una acción participativa, en la que se conjuga el quehacer docente con la investigación y la extensión artística en la comunidad.

Técnicamente, cada molde de látex es el resultado del contacto directo entre el cuerpo y el material, que, al catalizarse, registra la huella en negativo de esta superficie. Una vez seco, el látex líquido se desprende como si fuera una muda. Sin embargo, como veremos más adelante en los conceptos y la sistematización de las etapas del proceso técnico, también hemos implementado fases intermedias al registro de la matriz de látex, que nos permiten jugar con el grabado en relieve y bajo relieve de las huellas. Este proceso se ha desarrollado por más de una década, con la premisa de utilizar materiales no tóxicos y procedimientos poco invasivos, con los que procuramos mantener la integridad física del cuerpo y preservar su registro lo más intacto posible. La latexgrafía nos permite documentar estadios temporales de una superficie en transformación; así, cada impronta resulta ser una prueba de estado de un fragmento corporal que hemos resguardado del inminente paso del tiempo y cuya memoria gráfica se expande en el espacio (Fig. 1.1). 


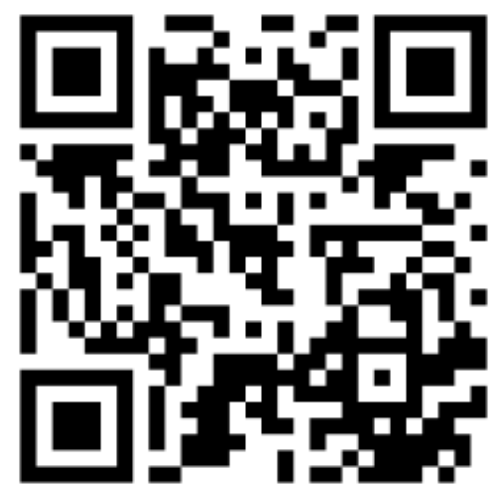

Fig. . 1.1. Cuerpo, tiempo, memoria. (2018). Introducción audiovisual a la latexgrafía (escanear QR para su visualización)

\subsection{PRINCIPALES CONCEPTOS DE LA TÉCNICA LATEXGRÁFICA}

A continuación, definiremos los términos que hemos acuñado como parte del componente técnico discursivo de la latexgrafía, con el fin de establecer un lenguaje común que sirva de hilo conductor a lo largo del presente estudio:

\subsubsection{MATRIZ PRIMIGENIA}

Se considera como matriz primigenia a la superficie material en la que originalmente se encuentran las texturas a transferir. Desde nuestra perspectiva, la experiencia vivencial y el factor temporal son los medios a través de los cuales se graban las superficies, ya sea de manera endógena, como es propio en los procesos de envejecimiento, o de forma exógena, en caso de ser el resultado de una acción externa al cuerpo. La piel que envuelve al cuerpo es esa superficie sensible que recoge dichos rastros y sobre la cual nosotros realizamos los moldes para replicar su memoria corporal. Por tanto, el cuerpo, entendido como matriz primigenia, puede 
ser el de una persona, animal o el de cualquier objeto que pueda ser registrado; dado que la latexgrafía tiene el potencial técnico para desdoblar las superficies en moldes; por ejemplo, la piel humana o la madera (Fig. 1.2). Si bien el proceso de la latexgrafía se formuló con la necesidad de trabajar en torno a las poéticas del cuerpo, la técnica va más allá de la huella humana, abriéndonos un mundo de posibilidades expresivas para trabajar a partir de diversas matrices primigenias en el futuro.
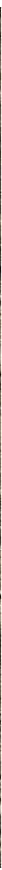

Fig. 1.2. Las superficies con las que hemos trabajado bajo el concepto de matriz primigenia: piel humana y madera (respectivamente) 
Es la impronta de látex proveniente de la matriz primigenia o molde. Se puede obtener mediante métodos indirectos y directos, pero en ambos casos siempre es el resultado del contacto entre una superficie emisora (piel, madera, etc.) y el material receptor (látex líquido). El método directo es cuando se vierte el látex sobre la matriz primigenia; al cabo de este proceso obtenemos una huella negativa de la superficie emisora (Figs. 1.3 y 1.4). El método indirecto corresponde a la impronta de un molde que previamente ha sido realizado, esta variable nos permite producir matrices latexgráficas tanto positivas como negativas, dependiendo de las características previas del molde (Fig. 1.5). En ambos casos, la particularidad de la matriz latexgráfica es su capacidad para replicar la superficie de la matriz primigenia o molde y convertirla en una segunda piel, ultradelgada que puede ser impresa en distintos soportes y también ser en sí misma un objeto artístico.

Tal y como se observa en las secuencias fotográficas, el látex natural es un líquido blanquecino que al entrar en contacto con el aire se cataliza; dependiendo del grosor de la capa, la humedad relativa del ambiente y temperatura, tarda entre cinco y quince minutos en secar por completo. En este proceso se transparenta y adhiere a la superficie, registrando detalladamente sus marcas. Para desprenderlo es preciso agregar talco para evitar que se pegue a sí mismo y poder tirar delicadamente de él. Gracias a su elasticidad y resistencia podemos realizar moldes muy delgados que al retirarse del cuerpo simulan la muda de la piel, conservando su forma intacta, o bien desgarrándola para subvertir la unidad simbólica del cuerpo. Dadas sus características físicas, al ser elástica y flexible, esta matriz nos permite jugar con la variabilidad de sus improntas. 

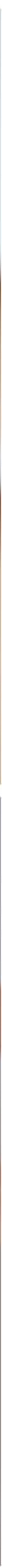

Fig. 1.3. Método directo de la latexgrafía sobre el cuerpo. El resultado de este proceso arroja una matriz negativa de la impronta de la piel, es decir, todas las marcas que están en bajo relieve en el cuerpo se fraguan en alto relieve sobre el molde (matriz latexgráfica). 

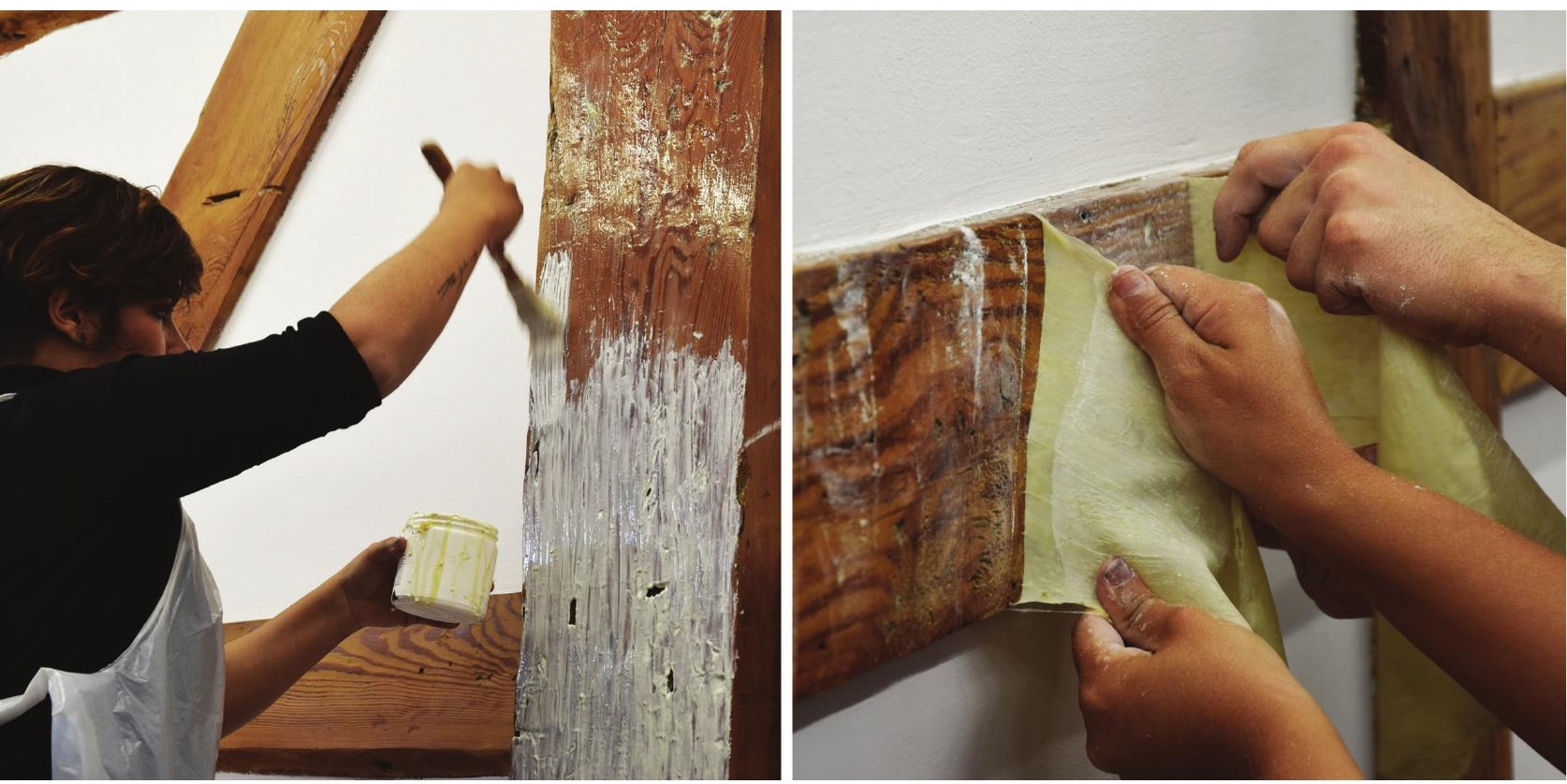

Fig. 1.4. Método directo de la laexgrafía sobre madera. Al igual que sucede con el cuerpo, las grietas en bajo relieve se invierten en la matriz latexgráfica. Esta experiencia se llevó a cabo en el espacio patrimonial del MOB y en el marco del proyecto Embodied Memory, 2019.
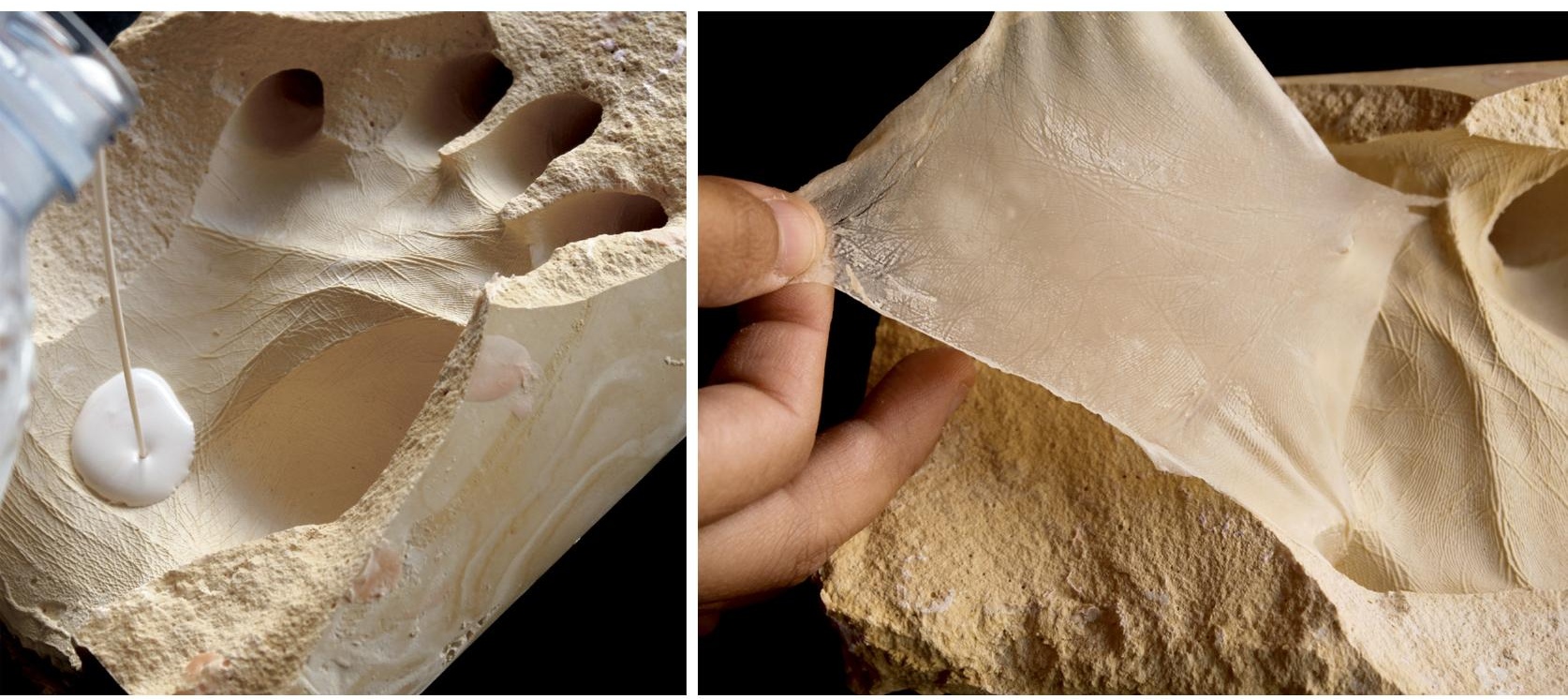


\subsubsection{HUELLA LATEXGRÁFICA}

Es el rastro visual y/o táctil proveniente de la matriz latexgráfica; se puede imprimir con tinta sobre un soporte bidimensional como el papel, o bien dejar su textura táctil sobre otros materiales como la escayola. Si comparamos la huella latexgráfica con una huella directa del cuerpo, podremos visualizar rápidamente las características que le dan identidad propia a nuestra técnica. Tal y como se observa en la imagen inferior (Fig. 1.6), a diferencia de la huella dactilar común, en la que solamente se llegan a imprimir las zonas mas prominentes del volumen corporal en un alto contraste, en la huella latexgráfica tenemos un registro meticuloso de la piel con todos sus relieves y matices tonales extendidos en un plano, incluyendo áreas casi imposibles de imprimir bidimensionalmente, como las uñas. Esto gracias a que la matriz latexgráfica al carecer de volumen corporal, se comporta como una segunda piel que se expande y adhiere temporalmente a la superficie receptora y deja su huella nítidamente impresa, tal como se observa en los pequeños fragmentos de escayola, en los que, en vez de utilizar tinta para registrar la huella, sacamos provecho del relieve y su tactilidad (Fig. 1.7).

Fig. 1.5. Método indirecto de la latexgrafía sobre un molde de escayola previamente realizado a partir de una mano. En tanto, la matriz latexgráfica proveniente de este proceso tiene una impronta positiva de la piel, es decir, una réplica de la epidermis tal y como la percibimos comúnmente al tacto. 


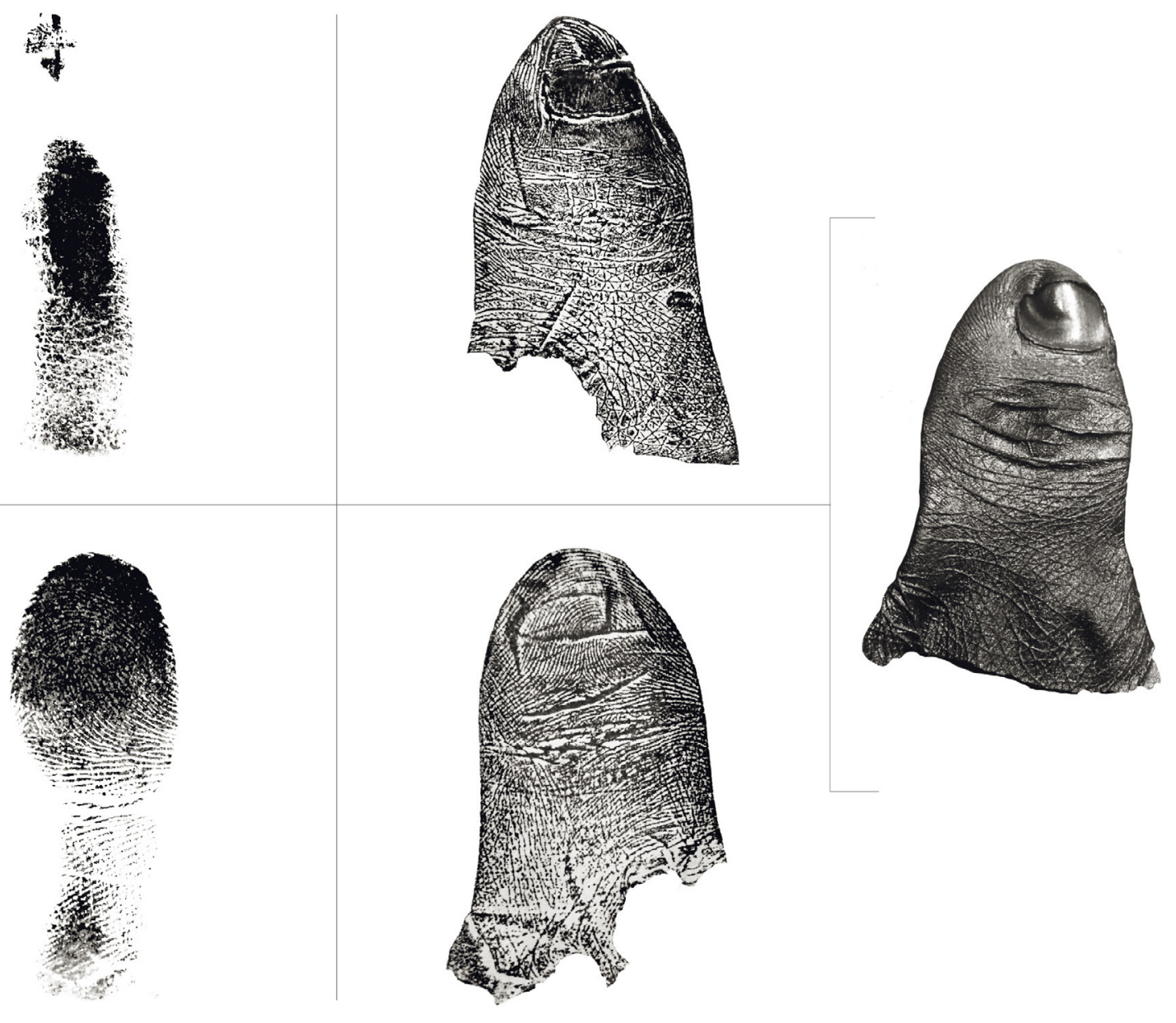

됩

Fig. 1.6. A la izquierda tenemos las huellas dactilares y a su derecha las huellas latexgráficas correspondientes al mismo dedo junto a su respectiva matriz. Ambas huellas se imprimen con el mismo tipo de tinta y de forma manual. La matriz latexgráfica utilizada fue obtenida mediante la forma directa (látex-piel); al ser de forma semicilíndrica podemos rodar e imprimir múltiples rastros de su forma sin que una impronta se repita a la otra, obteniendo siempre dos registros en cada tirada; ya que se coloca la matriz entre dos papeles. Este mismo procedimiento se puede llevar a cabo con otros materiales de soporte como la escayola. 


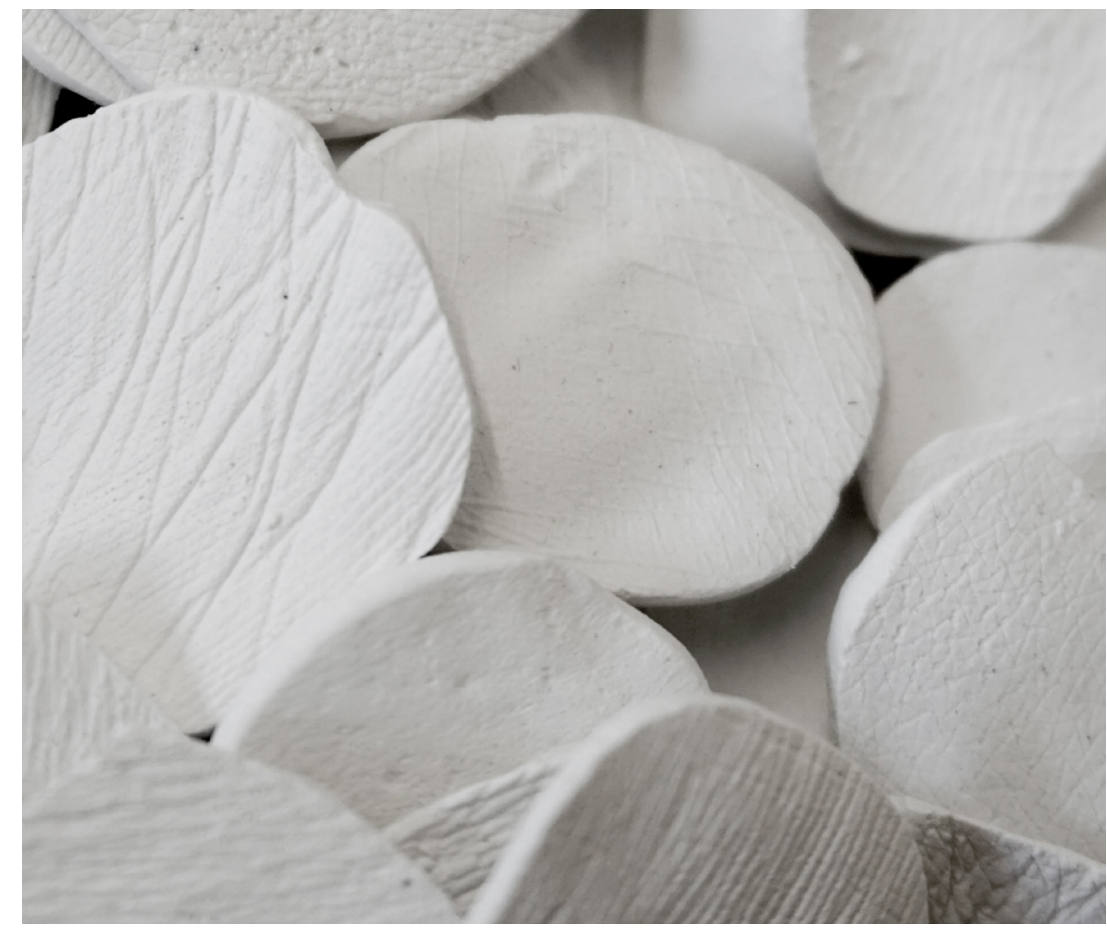

Fig. 1.7. Impresión de distintas huellas latexgráficas sobre escayola para el proyecto Living Treasure (2019). Dependiendo de la matriz latexgráfica, si ésta es en negativo o en positivo, así será su impronta reversa en la escayola, dejando las texturas en bajo o alto relieve.

La otra opción, que comúnmente utilizamos, es abrir y rasgar la matriz en el acto mismo cuando desprendemos el molde de la superficie emisora; para dislocar los nexos de referencialidad y literalidad. Es decir, en el momento en que arrancamos la delgada capa de látex de la piel o la madera, tiramos sin cuidar que este se desgarre y con ello, podemos extender los límites convencionales de la forma corporal, por ejemplo, unificar en una sola huella latexgráfica tanto la impronta de la palma con el dorso de la mano, en un juego expresivo en el que rotamos y giramos las matrices para obtener siempre una impresión distinta. A razón de lo anterior, observamos cómo desde la matriz latexgráfica de una mano abierta se registran distintas huellas, ya que se deja caer el molde aleatoriamente y cada vez que esto sucede se pliegan y repliegan nuevas formas que quedan impresas al ejercer presión vertical (Fig. 1.8). 


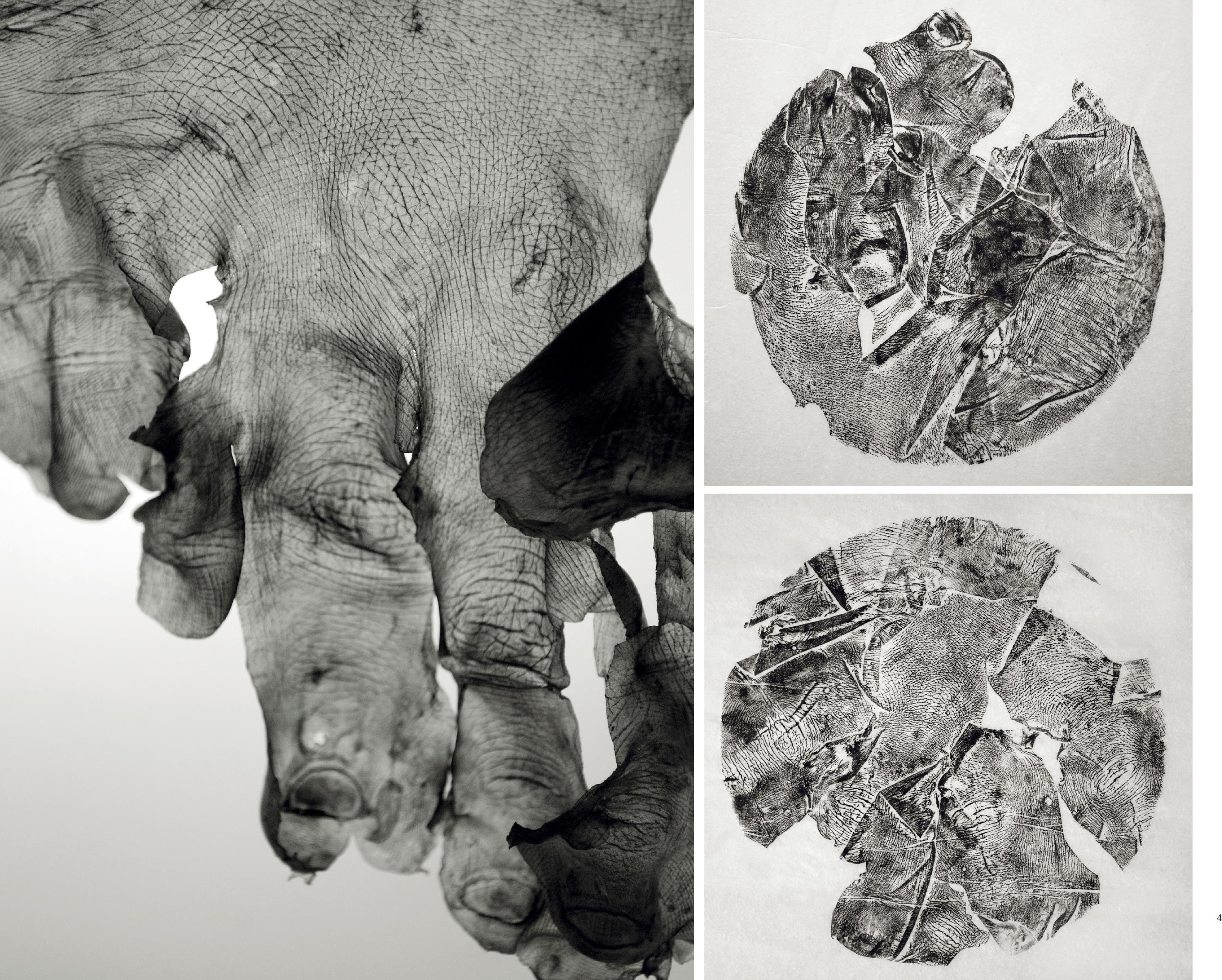


Fig. 1.8 En la primer imagen observamos la matriz latexgráfica de una mano de la cual realizamos más de quince impresiones, de las cuales mostramos dos de las mismas. Como se puede observar en las fotografías, estas improntas provienen de una misma matriz, pero gracias a la versatilidad del material y a la apertura del molde, jugamos con las múltiples posibilidades de sus variantes.

\subsection{SISTEMATIZACIÓN Y VARIABLES DEL PROCESO TÉCNICO}

Para llegar a obtener los resultados óptimos con los que hoy contamos, hemos continuado nuestra experimentación técnica desde los primeros hallazgos hasta la presente tesis. A continuación, expondremos las variables que intervienen en el proceso y sus respectivos descriptores, de esta manera respaldamos la sistematización técnica de la latexgrafía con la que contamos actualmente. A razón de la hipótesis planteada emprendimos un viaje creativo para construir una matriz a partir de moldes del cuerpo, la cual debería replicar las características formales de la piel y facilitar su impresión y reproducción en diversos soportes y materiales. Sin embargo, como es propio en la sistematización de una técnica de grabado y estampación, intervienen múltiples factores que se conectan. En nuestro caso estas interrelaciones están comprendidas en las variables del molde, matriz, tinta, soporte, entintado e impresión.

El proceso latexgráfico se ha nutrido históricamente de los avances que provee la industria de materiales e insumos para sacar moldes y prótesis en la odontología y la estética, ya que estos están testados para ser utilizados en el cuerpo, minimizando los factores de riesgo, aumentando su efectividad y rendimiento. De igual manera, hemos incorporado y adecuado en nuestro proceso instrumentos, materiales y herramientas austeras de uso cotidiano, para que la latexgrafía se extienda más allá de los límites de un taller convencional de grabado y pueda ser llevada a cabo en múltiples espacios informales abiertos a todo público y con un costo 
muy reducido. Cada una las variables que describiremos a continuación tienen criterios que inciden directamente en el resultado final, y pueden ser combinadas dependiendo de la intención creativa, lo que implica que el proceso de aprendizaje no cesa; por el contrario, con cada nuevo proyecto involucra una nueva meta por alcanzar.

\subsubsection{VARIABLES DEL MOLDE}

Tal y como mencionamos en la definición de la matriz latexgráfica, ésta se puede obtener de manera directa, vertiendo el látex sobre la piel/superficie emisora, o bien utilizando un molde previo. Para efectos de requerir el molde previo (ya sea por la fragilidad o sensibilidad de la superficie emisora o alergia al látex), este material debe cumplir con una serie de requerimientos que nos permitan mantener la calidad del proceso, tales como: la máxima fidelidad del registro, el tiempo de trabajo y fraguado manejables para manipular el material y poder sacar correctamente los moldes, nula toxicidad para la piel, durabilidad, resistencia y precio asequible, así como su fácil adquisición en el mercado. Según se fueron evaluando los resultados de la experimentación, pudimos determinar tres materiales óptimos para extraer moldes, los cuales son en orden de prioridad y rendimiento los siguientes: el alginato, la escayola y la silicona para prótesis corporales.

Cada uno tiene características distintas que utilizamos según qué resultado esperamos. Por ejemplo, si es un fragmento pequeño del rostro, cabello o genitales, nos decantamos por el alginato para uso odontológico con variación cromática, ya que poseen indicadores de ph que nos advierten de cada una de sus fases de trabajo con un cambio en su coloración. Este producto es de origen natural, se industrializa a partir de algas marinas pardas, de ahí su nombre. Está diseñado para fraguar al contacto con el agua y no ha presentado reacciones cutáneas en los participantes. Este material registra las texturas de las superficies extraordinariamente bien y rápido (dos minutos en promedio), y no requiere desmoldante ya que prácticamente no se adhiere a nada, sin embargo, al perder la humedad al cabo de los días se vuelve frágil y, a largo plazo, se encoje. Estas 
características hacen que utilicemos el alginato como medio previo al mismo alginato, en caso de querer sacar el positivo, así como del látex o la escayola, pero no es el indicado para conservar la huella indefinidamente. Para esos efectos lo propio es la escayola, dada su durabilidad, estabilidad y bajo costo.

En el caso de las escayolas protésicas, utilizamos la conocida como tipo piedra o número $\mathrm{V}$, ya que es de gran dureza y resistencia, no necesita tanta agua para mezclarse ya que el polvo es muy fino y no presenta grumos, tarda 15 minutos en secar (en capas delgadas), lo que nos permite mayor manipulación y una extraordinaria fidelidad en el registro. Como es sabido, los moldes resultantes de este material son rígidos, por lo que la utilizamos para sacar los positivos/negativos del alginato y conservar la forma por largo tiempo, lo cual sólo sucede en circunstancias excepcionales en las que, por motivos personales, decidimos dejar un molde de una persona; este fue el caso del molde positivo del rostro que dio origen a la obra Imaǵo (2021), (Fig. 1.10).

La silicona para prótesis médicas ha sido nuestra última incorporación a la palestra de materiales para moldes, y presenta un excelente registro, sin embargo, su costo es muy elevado y el tiempo de secado puede extenderse hasta una hora, motivo por el cual no la utilizamos tan frecuentemente. A pesar de ello, intentamos realizar un molde de todo el cuerpo, pero perdimos el conocimiento en el proceso debido a la hipersensibilidad que provocaba tener la totalidad de la piel cubierta por el material, hecho que nos causó una crisis de ansiedad. Por este motivo, sólo contamos con los moldes negativos de las manos y pies que pudimos rescatar del proceso (Fig. 1.11). Estos, nos ha dado un excelente rendimiento, ya que son flexibles, muy resistentes y no se adhieren a ninguno de los materiales con los que trabajamos. 

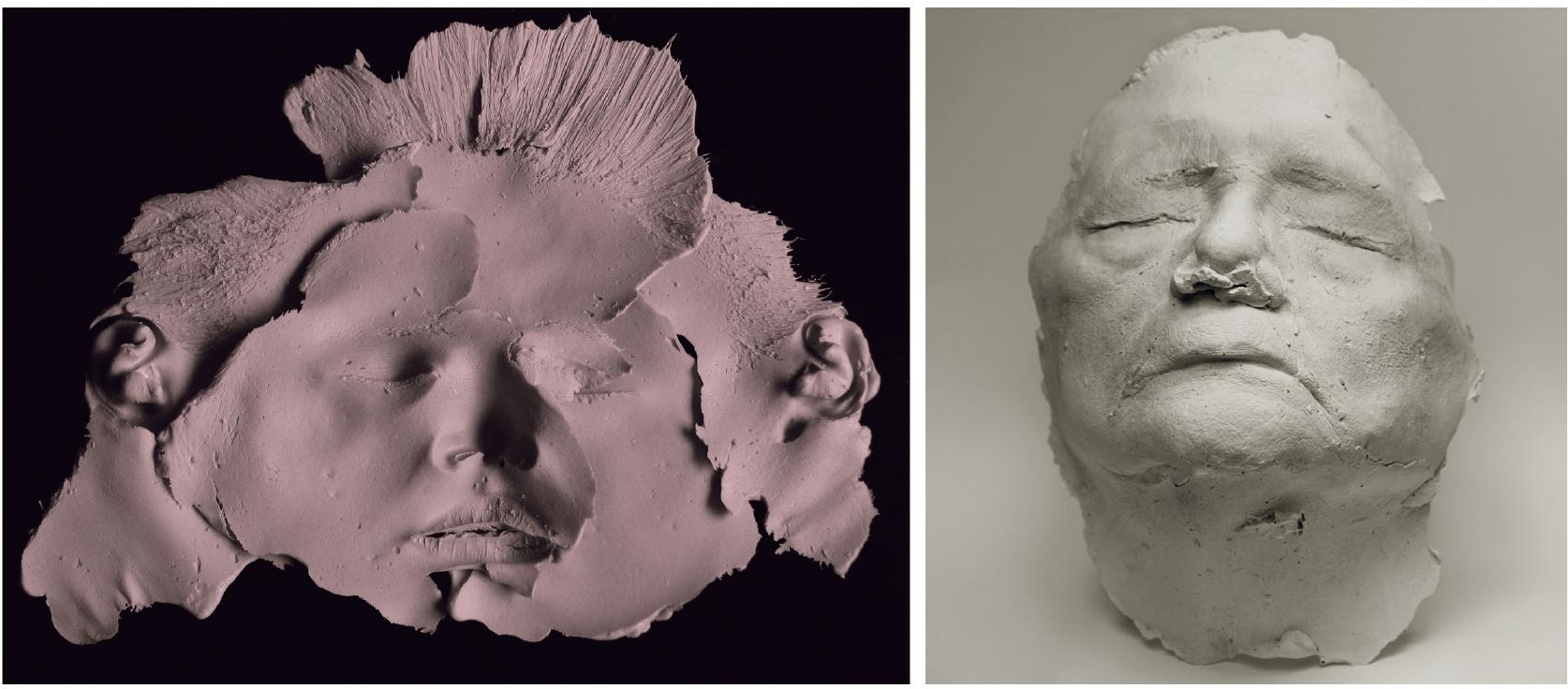

Fig. 1.10. En estas imágenes mostramos primeramente un molde del rostro de la artista en negativo, realizado en de alginato cromático (rosa) y fragmentado por partes en el proceso de su realización. A la derecha, la máscara en positivo del retrato de la abuela de la artista, proveniente de un molde previo de alginato. Esta última pieza tridimensional dio origen a la obra Imaǵo (2021). Ambos moldes han servido de superficie emisora para múltiples matrices latexgráficas.
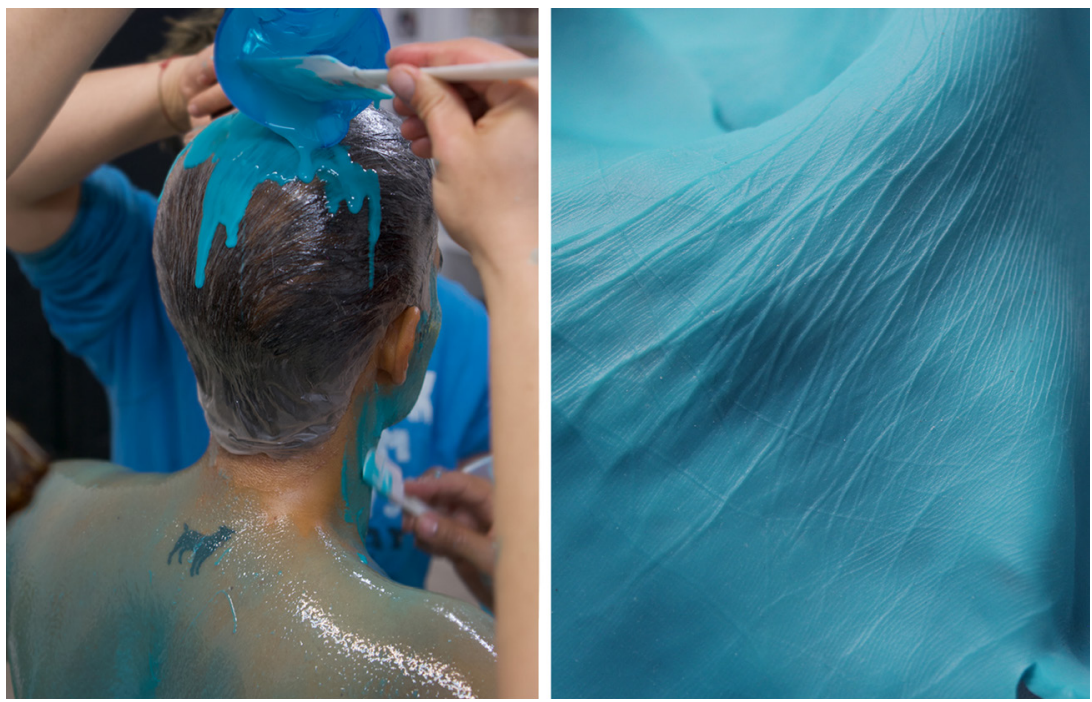

Fig. 1.11. Proceso y molde negativo de silicona protéstica, respectivamente. Dado a que no se pudo conseguir el objetivo de replicar la piel del cuerpo por completo, contamos con fragmentos que han sido utilizados para realizar tanto moldes en positivo en alginato, como matrices latexgráficas e improntas sobre escayola. 


\subsubsection{VARIABLES DE LA MATRIZ LATEXGRÁFICA}

El látex líquido natural proviene del árbol Hevea brasiliensis, mejor conocido como el árbol de hule o caucho. La abundante savia blanquecina que luego se industrializa para vulcanizarla, se obtiene al rasgar y cortar la corteza del árbol, lo que dota a este material de un contenido poético vinculante con nuestro discurso, ya que es un fluido que emana al retirar parte del córtex del árbol. Técnicamente, el látex es un polímero coloidal, motivo por el cual lo utilizamos en nuestras matrices, ya que emula las características de la piel, como la elasticidad, resistencia y translucidez. Hace una década que iniciamos nuestra experimentación hacia la latexgrafía y no hemos encontrado otro material que rinda igual o mejor que el látex líquido natural para los fines que nosotros lo utilizamos. En aquel entonces conseguimos un suplidor en Valencia, el cual importaba el producto a granel, y con esas muestras hicimos las primeras pruebas. Sin embargo, la experiencia nos ha llevado a buscar distintas marcas de las cuales destacamos la excelente calidad de Holden 's latex, específicamente el HX-407, ya que, según los datos del fabricante y corroborado en nuestro proceso creativo, es un látex prevulcanizado, con alta viscosidad y
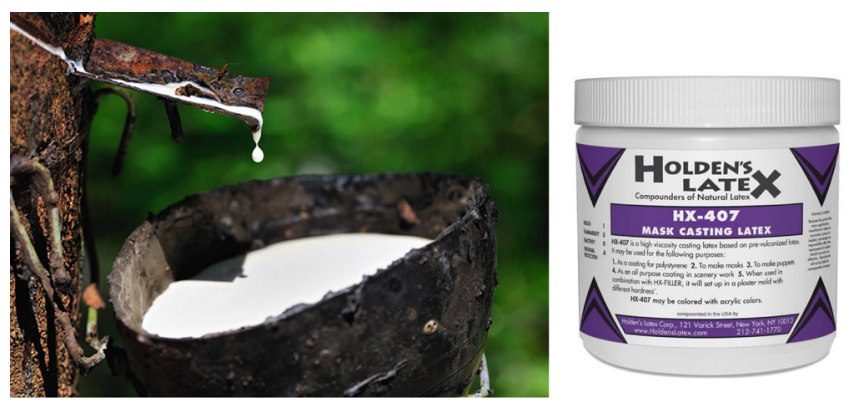

Fig. 1.12. Esta imagen ilustra el material en bruto al ser extraído del árbol de caucho y a su derecha el látex manufacturado que utilizamos en la gran mayoría del proceso latexgráfico para elaborar nuestras matrices 
especial para capas delgadas y moldes huecos, como máscaras y efectos especiales (Fig. 1.12). En resumen, este producto cumple con creces los requerimientos buscados: alta fidelidad en el registro, tiempo de fraguado menor a diez minutos, alta resistencia, permeabilidad y durabilidad, excelente recepción de la tinta al agua, transparencia y buen precio.

En cuanto al nivel de toxicidad y alérgenos, existen otras marcas que ofrecen látex hipoalergénicos y/o bajos en amoníaco, como Environ Molds. Sin embargo, cuando hemos dado con personas con alergia al látex hemos recurrido a realizar previamente un molde de alginato para luego sacar el positivo con el mismo material, y desde estas superficies extraer las matrices, ya que los látex hipoalergénicos son frágiles, quebradizos y de mayor costo. Por tanto, los tipos de matrices latexgráficas varían en cuanto a la calidad del suplidor, pero no en la escogencia misma del material, ya que sus características físicas y químicas siguen siendo las idóneas para nuestro trabajo; tanto así que actualmente las matrices las consideramos como objetos artísticos y pasan a formar parte del corpus de obra de nuestra investigación, como por ejemplo en la obra Second skin (2019), expuesta al público del MOB en el marco del proyecto Embodied Memory (Fig.1.13). Otro factor diferencial es el que categoriza las matrices latexgráficas según su tipo de impronta, ya sea esta positiva o negativa, si provienen o no de un molde previo o son resultado del contacto directo entre el látex y la piel. 

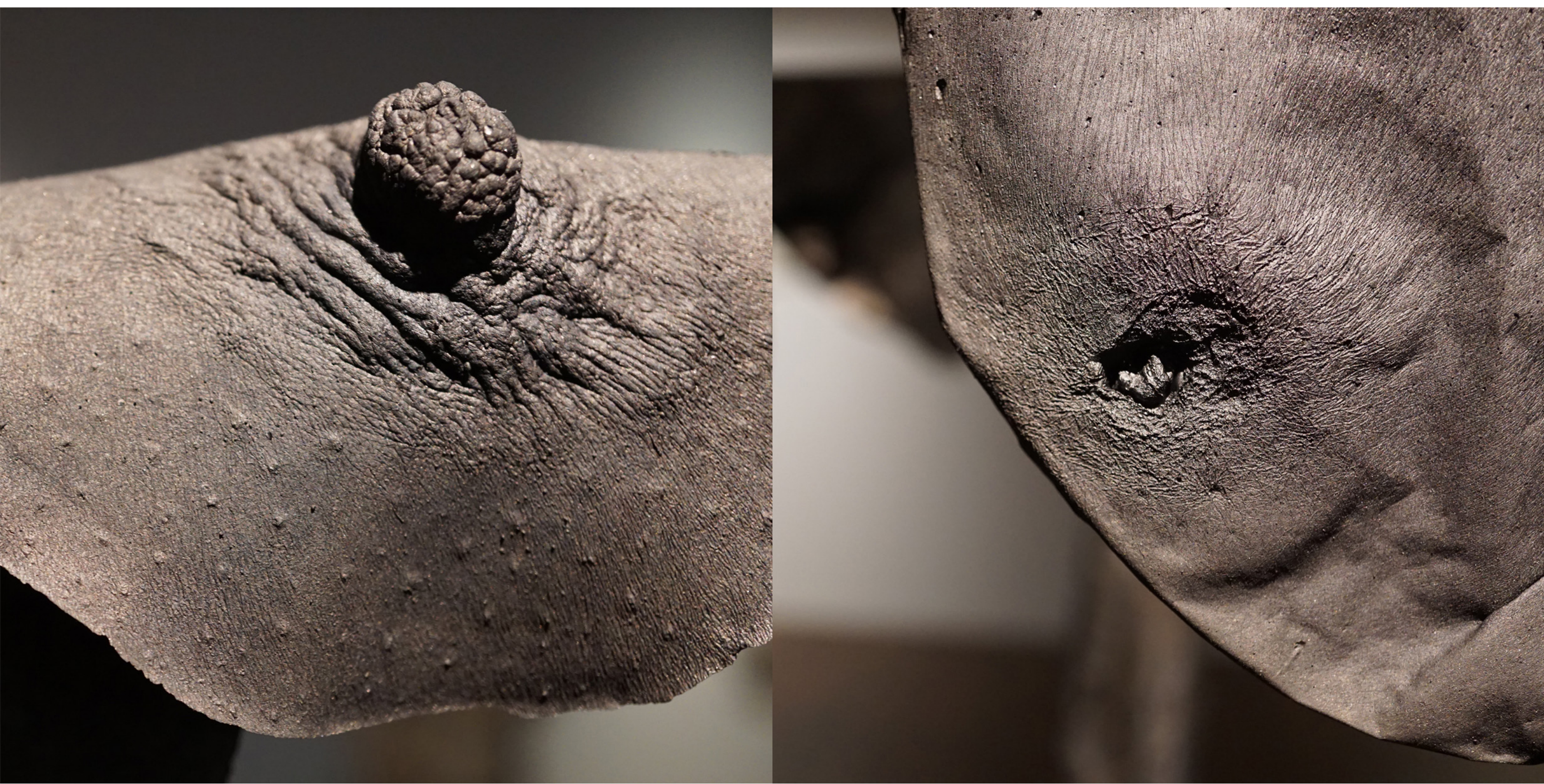

Fig. 1.13. Estas dos matrices latexgráficas provienen de pechos, la primer imagen es una impresión positiva de un molde negativo del cuerpo, y la segunda es una impronta negativa, extraída directamente de la piel. Tal y como se aprecia, a pesar de no pertenecer a la misma persona, ambos pechos ejemplifican con el volumen cóncavo y convexo de los pezones, la versatilidad y fidelidad del registro que nos ofrece la técnica latexgráfica. 


\subsubsection{VARIABLES DE LA TINTA Y ENTINTADO}

Al igual que sucede con el látex, la tinta indeleble a base de agua para sellos de caucho, ha sido la mejor opción para las impresiones sobre papel por más de una década. Desde los inicios de la latexgrafía hemos utilizado múltiples pigmentos dentro de nuestra experimentación, sin embargo, al descartar las sustancias que requieren de disolventes que destruyen la matriz de látex, nos quedamos con la gama de tintas solubles en agua, tales como pigmentos en polvo, tinta china, tinta de inyección o tinta india, siendo la tinta para sellos la mejor solución, por lo que en la presente investigación nos hemos dedicado a buscar la que mejor rendimiento tenga en el mercado y que se ajuste a nuestras demandas. Este producto es la tinta negra marca Trodat y la Coloris, ya que nos permiten registrar una huella impecable con un alto nivel de gradación tonal, dejando impresos hasta los detalles más delicados. Esta tinta negra cumple con la norma de calidad internacional DIN ISO 11798 para la información y documentación impresa que garantiza los estándares de permanencia, durabilidad y legibilidad, regulando los parámetros de resistencia al calor, la luz, la abrasión y el agua. Nuestras matrices se conservan con la tinta y esta no daña el látex, y en caso de requerir limpiarlas del exceso de pigmento, se lavan con agua y jabón o un poco de alcohol, sin que este proceso afecte mínimamente su integridad.

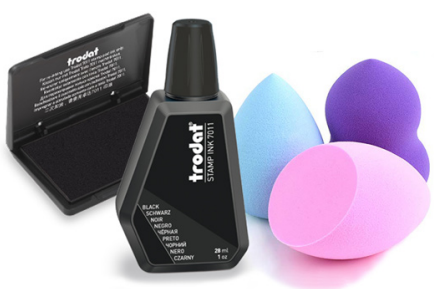

Fig. 1.14. Kit de entintado utilizado en el proceso latexgráfico: Tinta y tampon Trodat, y esponjas Beauty Blender

La otra variable que incide en el proceso de entintado nos vincula de nuevo con el cuerpo y los instrumentos estéticos que han sido diseñados y testados para la aplicación de maquillaje sobre la piel (Fig. 1.14). Estamos hablando de las esponjas que utilizamos para entintar nuestras matrices 
latexgráficas, ya que debido a que estas últimas se comportan como la epidermis, debemos tratarlas como tal. En una primera etapa de nuestra investigación, probamos múltiples instrumentos y métodos de entintado; desde el clásico rodillo de grabado hasta el pincel, el aerógrafo o el frottage, sin éxito alguno, hasta que dimos con los tampones Trodat y las esponjas de maquillaje, las cuales han evolucionado notoriamente en los últimos diez años. Actualmente utilizamos las esponjas llamadas Beauty Blender, ya que están hechas de una microfibra con textura porosa y aterciopelada que deja un acabado uniforme sobre la superficie receptora. Entre otras muchas ventajas, esta esponja viene en múltiples formas ergonómicas, lo que nos permite entintar manualmente desde las áreas más irregulares hasta las más planas y lisas, y absorben el pigmento justo sin saturarse ni dejar excesos de tinta sobre el látex. Lo anterior se traduce en unas huellas latexgráficas impecablemente impresas, sin marcas de rodillo ni de ningún otro instrumento.

\subsubsection{VARIABLES DEL SOPORTE E IMPRESIÓN}

Esta variable se vincula directamente con los criterios que definen la huella latexgráfica, ya que en un principio sólo se habían contemplado soportes bidimensionales como resultado final, pero en el marco de la presente tesis se amplió el campo de acción a materiales y soportes tridimensionales, como lo son las improntas sobre escayola. Por ende, la huella latexgráfica tiene la capacidad de imprimir su registro tanto a nivel visual como táctil; todo depende de la naturaleza del material/ soporte que se emplee como superficie receptora. En caso de los soportes bidimensionales la impresión se realiza ejerciendo presión manual con el brazo o un rodillo común, por medio de un tórculo de grabado o bien una prensa vertical, ya sea casera o industrial. Lo imprescindible es, en todos los casos, colocar una capa de espuma viscoelástica (yoga mat, sin textura) por encima del papel y la matriz, para amortiguar la presión; ya que este material permite que la fuerza sea uniforme y se transfiera hasta el último detalle en el papel. Gracias a las particularidades de algunas matrices latexgráficas, en tanto que objetos reversibles y semicilíndricos, podemos imprimir dos improntas en una sola tirada, por ejemplo, al 

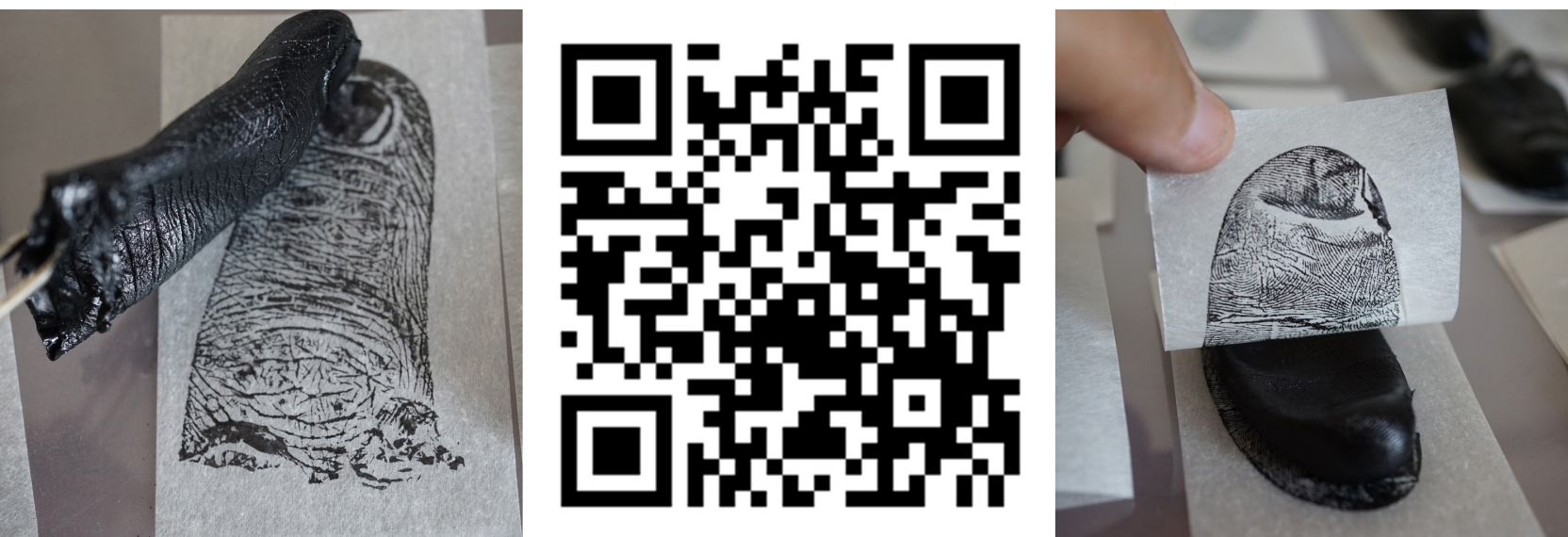

Fig. 1.15. Algunos ejemplos del proceso de impresión latexgráfica en el marco de la producción de la obra Digital Archive (2019), utilizando métodos manuales y austeros, tal y como se observa en el video del $\mathrm{QR}$.

imprimir un dedo entero colocamos su molde entre dos capas de papel o dos capas de escayola, de esta manera obtenemos registros tanto de la yema como la huella dactilar y la uña (Fig. 1.15).

En cuanto a los soportes bidimensionales la gama de papeles japoneses tipo Washi, específicamente los gampi, entre 10-12 gramos, son los de mejor rendimiento (Fig. 1.16). Estos papeles trascienden el valor de lo meramente instrumental, ya que más que un soporte para nuestras estampas son en sí mismos un bien artístico, siendo declarados Patrimonio Cultural Inmaterial de la Humanidad en el 2014, gracias a su invaluable aporte a las artes gráficas, haciendo valer la tradición artesanal milenaria a nivel mundial. A diferencia de muchos de los soportes disponibles en el marcado, el gampi es un papel realizado completamente a mano, extraído de las fibras naturales de la planta que da su nombre. Entre las características más relevantes para nuestro estudio se encuentra su enorme parecido a la membrana de la piel, que al ser translúcido permite que la impresión sea prácticamente reversible y sedoso al tacto. 


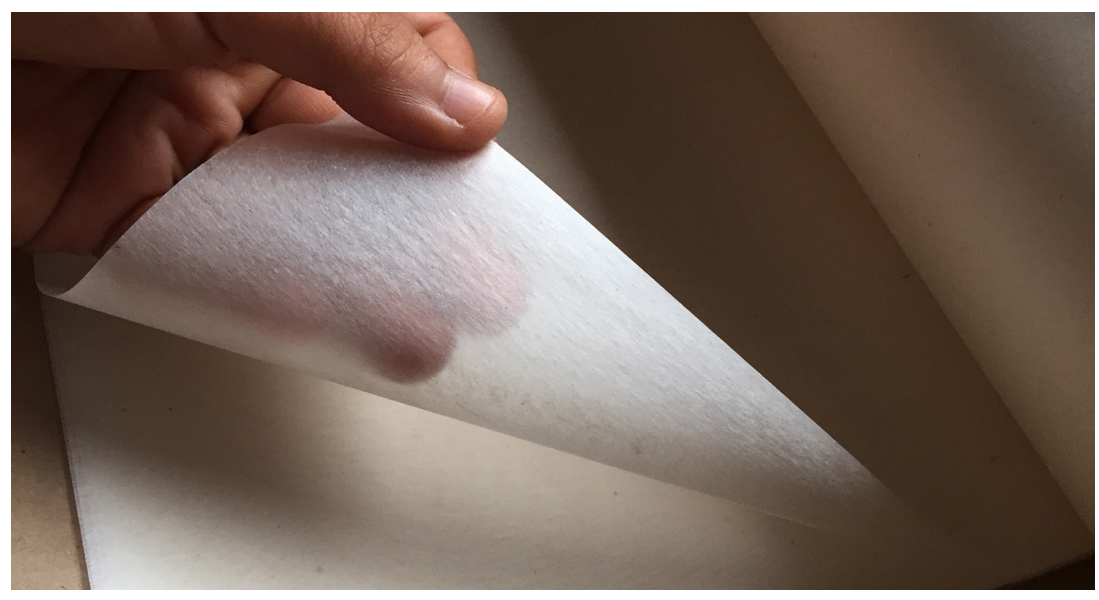

Fig. 1.16. Muestra del papel gampi de $12 \mathrm{~g}$ con el que trabajamos en nuestro estudio.

Gracias a su ligereza y extraordinaria resistencia, permite dar movimiento y sutileza a nuestras improntas sin dejar de lado su apariencia delicada y superficie lustrosa. Al no tener textura táctil y muy poca interferencia visual, no compite con la trama de la huella latexgráfica; se puede jugar con los pliegues y es óptimo para adherirse a otros papeles con el método del chine-collé, tal y como lo hemos realizado en varias de nuestras obras, entre las que se encuentra El pliegue I (2021). Finalmente, pero no menos importante, es el factor químico que lo categoriza como material estable y libre de ácido, además, en la savia natural de su materia prima se encuentran sustancias tóxicas y repelentes para los insectos, hecho que le da aún más importancia en términos de conservación y preservación de archivo (Fig. 1.17). 
Además de los papeles japoneses, en nuestras más recientes experiencias hemos utilizado láminas de poliéster para litografía digital conocidas como pronto-plate, ya que tienen cualidades como la translucidez y resistencia, la impermeabilidad al agua y excelente recepción para la impresión láser (Fig. 1.18). Esta alternativa nos ha permitido escanear impresiones realizadas sobre papel gampi y trasladarlas a un archivo digital para ser impresas en alta resolución y escala real. Gracias a esta solución, pudimos incurrir en el grabado digital y subsanar, en el marco de la pandemia, el desabastecimiento de los materiales con los que comúnmente trabajamos. Estas circunstancias nos impulsaron a dar un giro hacia el mundo virtual y las poéticas de la memoria intangible en obras como Imaǵo (2021). Si bien nuestro proceso se realiza y justifica enteramente desde lo manual, creemos que las cualidades que nos brindan los nuevos medios de impresión y soportes alternativos, nos ayudan a ampliar el panorama de nuestra investigación en la gráfica expandida.
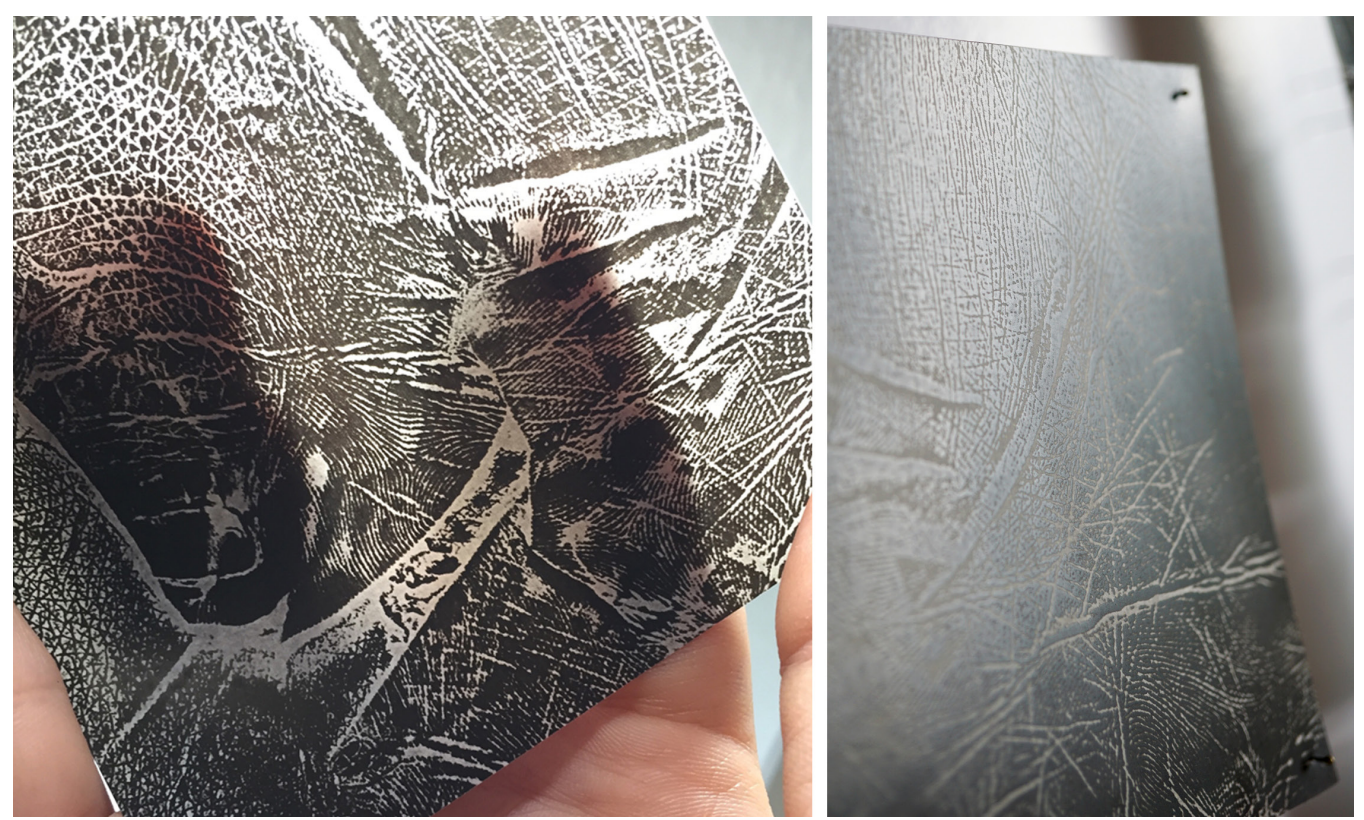

Fig. 1.18. Impresión laser sobre la matriz de poliéster para litografía digital: pronto-plate. Sobre este polímero se imprime la imagen en alta resolución de una huella latexgráfica que previamente había sido registrada manualmente sobre papel gampi. 
En caso de utilizar la escayola como soporte receptor de la huella latexgráfica, se debe preparar la mezcla de manera que permita aplicarla directamente sobre la matriz de látex, es decir, con el nivel justo de agua para que no "chorree" y nos de tiempo suficiente de maniobra. Con este procedimiento podemos imprimir la textura táctil del molde de látex y registrar todas sus variantes de movimiento en diferentes improntas de escayola. Tal y como podemos observar en las imágenes, al utilizar la matriz de látex como superficie emisora y la escayola como material receptor de la huella, podemos doblar y plegar el látex para que trasfiera las texturas nítidamente y alterar la forma original de la matriz primigenia de la que originalmente provienen. Este es el caso de las improntas realizadas a partir de las columnas de madera patrimonial del MOB durante el proceso de impresión de Splinters of time, (2019); gracias a que corrugamos el látex intencionalmente, la superficie de la madera tomó forma de pliegues epidérmicos (Fig. 1.19).

Este mismo proceso de impresión se llevó a cabo en la obra Living treasure (2019), en la que realizamos más de quinientas improntas circulares a doble cara que simulaban pequeñas monedas con sus respectivas caras y cruces. Técnicamente se resolvió utilizando matrices latexgráficas de la piel, sobre las cuales se vertía una pequeña porción de escayola, luego se ejerció presión hasta que obtuvimos una capa ultradelgada del material. Por tanto, a manera de "bocadillo", la escayola fresca se fraguó entre dos capas de látex que dejarían su huella impresa fielmente sobre ella (Fig. 1.20). 

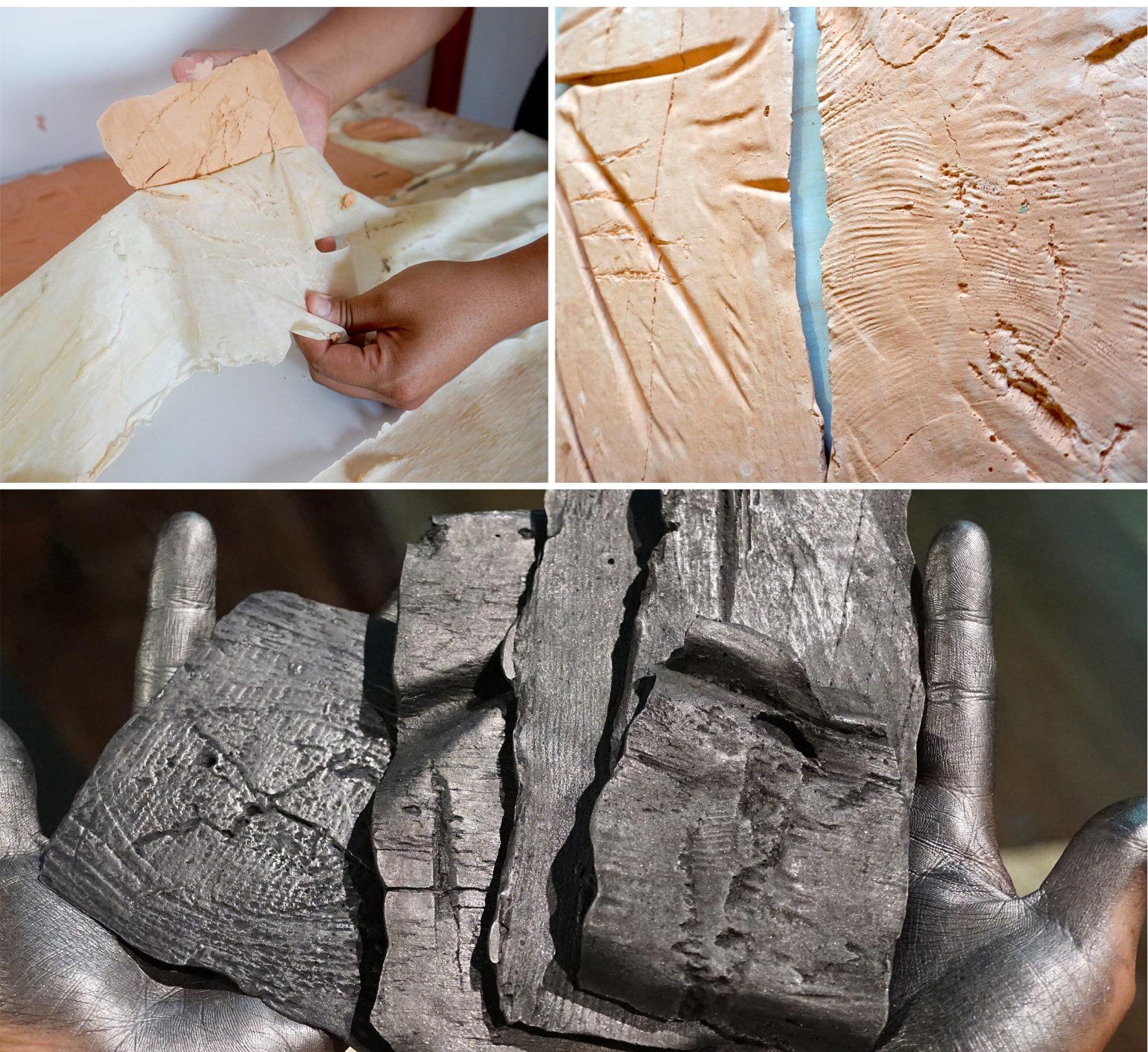

Fig. 1.19. Ejemplos de impresión latexgráfica sobre escayola en el proceso creativo de Splinters of time (2019). Una vez impresas las huellas se impregnan de tinta hasta que la escayola se torne negra y posteriormente se entalcan manualmente con polvo de grafito para simular la apariencia de madera quemada/carbón. 

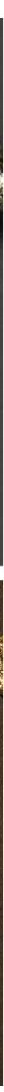

Fig. 1.20. Se observa primeramente una matriz latexgráfica sobre la cual de imprimen las pequeñas monedas de escayola, las cuales tienen textura en ambas caras y no superan los $2 \mathrm{~mm}$ de grosor. Posteriormente se doran con pan de oro de 24 kilates para dar el acabado final. Mas de 300 ejemplares como este conforman la obra tridimensional del conjunto

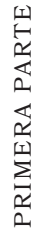
de Livinǵ treasure (2019). 


\subsection{LATEXGRAFÍA Y GRÁFICA EXPANDIDA}

En este apartado, revisaremos los cimientos de lo que concebimos como gráfica expandida en el marco de nuestra tesis; con el fin de trazar un camino que nos ayude a comprender y contextualizar cómo el carácter experimental del grabado ha sido una constante histórica, que ha hecho posible que sus fronteras sean cada vez más porosas, diluyendo poco a poco los límites que lo constriñen a una práctica artesanal, para sumar lo mejor de la tradición técnica a los nuevos auges conceptuales y procesuales en las artes visuales hoy en día. Con el propósito de acotar esta breve intervención, partimos desde los discursos que se gestaron en el giro posmoderno a mediados del siglo XX, donde se potencializa la expansión entre las disciplinas y medios artísticos, extendiéndose hasta las prácticas no específicas en nuestra contemporaneidad.

Como veremos, la gráfica expandida lejos de ser una "nueva" perspectiva se ha venido macerando con el tiempo; el suficiente para dejar un rico caldo de cultivo, para que propuestas, como la nuestra se sustenten. Este factor es un aliciente, ya que implica que el espíritu subversivo, que originó la expansión de los límites del grabado tradicional, pervive anacrónicamente hasta hoy. Lo cual nos permite seguir problematizando y re-definiendo este medio expresivo en cada momento histórico, tal y como pretendemos hacerlo desde la sistematización técnica y reflexión conceptual de la latexgrafía; a través de la cual abrimos las fronteras de la representación y percepción del cuerpo, al expandir la memoria gráfica encarnada en las huellas de la piel sobre un soporte expresivo.

A continuación, revisaremos y puntualizaremos los antecedentes teóricoconceptuales de la gráfica expandida con los que nos identificamos y, en una segunda parte, estableceremos un diálogo con las nociones más representativas de la gráfica actual, exponiendo una serie de artistas que, si bien no todos forman parte de nuestros referentes específicos (desarrollados en el apartado 2.4 Corporalidades en (Con)tacto), son imprescindibles para nuestro estudio. 


\subsubsection{TRAS LAS HUELLAS DE LA EXPANSIÓN GRÁFICA}

¿Cómo no empezar hablando delimprescindible aporte de Rosalind Krauss, en su ensayo La escultura en el campo expandido, publicado inicialmente en la primavera de 1979 en October 8?, Sin embargo, si bien es un texto fundamental que expondremos más adelante, enfatizaremos previamente las bases propuestas por The New York Graphic Workshop (TNYGW), grupo consolidado por Luis Camnitzer, José Guillermo Castillo y Liliana Porter en 1964. Tres artistas latinoamericanos que consideramos como referentes principales de la noción de la expansión gráfica interdisciplinar con la que comulgamos en esta tesis; no sólo por la fecha en la que se gestaron sus manifiestos, sino por el posicionamiento autocrítico de los mismos, donde evalúan a fondo el carácter y los desafíos específicos del grabado, los mismos que citaremos a continuación, compilados en la publicación de Camnitzer (1969), titulada Texto, la cual forma parte del catálogo de la exposición que el grupo TNYGW realiza en enero de ese mismo año en el Museo de Bellas Artes de Caracas, Venezuela.

En este documento, Camnitzer pone en manifiesto la necesidad de repensar el grabado desde sus entrañas, para construir un discurso que articule la visión histórica del mismo, mediante su categorización conceptual y técnica, donde se incluya la tradición y los nuevos espacios de inserción en el diseño y la industria de la imprenta; así como su dimensión didáctica; tal y como él mismo lo apunta: "El simple hecho de ponerse a escribir sobre Grabado parece una actividad anacrónica. Lo es además, salvo de que en este caso sirva de punto de partida para una cantidad de otras cosas." (Camnitzer, 1969, párr. 1). Son, precisamente, "esas otras cosas", las que más nos interesan en nuestro estudio, dado que una vez que el grabado se descarga de su carácter meramente reproductor, se afronta con mil desafíos, comenzando por el hecho de que su multiplicidad desvirtúa el valor que históricamente en occidente se le otorga a la obra de arte como única e irrepetible. A razón de lo anterior, el crítico plantea la siguiente reflexión con la cual coincidimos: 
¿Cómo es posible que un medio de expresión quede tan aislado e intocado por los cambios radicales que pasan a su alrededor?... que no solamente no trate de incorporarse al proceso dinámico que lo rodea, sino que ni siquiera asimila los aportes que se le están mostrando? Una de las posibles razones es el planteo eminentemente técnico que el Grabado supone. El marco de referencia artesanal en el que se mueve permite al grabador pensar en una acumulación cuantitativa de subtécnicas, sin preocuparse por los conceptos esenciales que podrían trascender ese marco de referencia y permitir una revisión cualitativa de todo el proceso. (Ibidem, párr. 6 y7)

En vista de este objetivo trazado por el colectivo, Camnitzer transcribe el primer manifiesto en 1964, (el cual se publica en Texto), y se retoma posteriormente en la revisión retrospectiva del TNYGW que él realiza en la Revista del Instituto de la Cultura Puertorriqueña. A continuación, un breve resumen de esta propuesta:

De aquí llegamos a la idea del "objeto", trascendiendo las ideas tradicionales de la pintura y de la escultura. El grabado nos da no solamente la posibilidad del objeto sino de la edición de objetos...Los grabadores epigonean (sic) tras las artes y viven encerrados en su propia cocina artesanal. Ha llegado el momento de que asumamos la responsabilidad de revelar nuestras propias imágenes, condicionadas, pero no destruidas por nuestras técnicas. (Camnitzer, 2004, p.1)

Es decir, el grabado entendido como objeto teórico y artístico, va más allá de la fascinación que nos producen las técnicas y las recetas de su cocina, sino que también contempla los supuestos históricos que no le permite empoderarse para salir de la marginalidad y dejar de ser visto como un arte menor al servicio de las mayores, un precepto que, aunque nos parezca ya superado, en el mundo fuera de nuestro circuito aún impera. Por tanto, todo parece depender de la intención del artista y cómo esta persona concibe y proyecta al público el proceso en el que está inmerso. A razón de lo anterior, Candiani (2018) plantea que desde el enfoque del New York Graphic Worshop ya se concebía -desde los años 60- al grabado como "una superficie productora de imágenes", que se imprimen mediante un "vehículo" sobre un "receptor", en donde el primero no se limita a la tinta y el segundo no tendría porqué ser necesariamente el 
papel, así mismo, la posibilidad de su multiplicación serial no sería el común denominador que lo define estructuralmente, por lo que su diseminación ha cobrado nuevos sentidos en las prácticas artísticas que se insertan en el tejido social y político.

Desde nuestro punto de vista, creemos que es más importante reflexionar en la acción, alrededor del acto de imprimir la huella y el contacto con la materia, que detenernos en la edición estable e idéntica, ya que lejos del virtuosismo que amerita esta práctica, hoy día, hay tecnologías que nos garantizan la exactitud de las copias. Por otra parte, creemos que lo que emite la matriz no es una copia sino un multioriginal y lo que se reproduce en nuestra experiencia técnica es precisamente la diferencia, la versatilidad que nos provee la matriz latexgráfica. Por estas razones, este primer manifiesto, representa un temprano llamado a la toma de conciencia de los artistas que hacían grabado, para que se responsabilicen y valoren los alcances que tiene este medio de expresión, los mismos que se fortalecen en la medida en que se conozcan los supuestos que condicionan su "dimensión mítica", tal y como lo propone también Martínez Moro (2008), cuando plantea que existen tres grandes razones que aún pesan sobre las espaldas del grabado, la primera, es el desconocimiento del medio, la segunda, el exceso de tecnicismo que lo vuelve inaccesible para la mayoría y, por último, el factor de lo múltiple versus el original.

En 1966 surge la necesidad en el grupo de TNYGW de emitir un segundo manifiesto, una vez que se ha madurado el concepto del objeto impreso, para plantear la dimensión polisémica del FANDSO (Free Assemblable Nonfuctional Dispoble Serial Objetcs) (Objetos seriados, prescindibles, afuncionales y libremente intercambiables). Un concepto, que, desde nuestra perspectiva, responde a una búsqueda por configurar una unidad de sentido del grabado, suficientemente flexible como para albergar obras y acciones de toda índole, tanto bidimensionales como tridimensionales, la huella como acción performática participativa, así como el papel del espectador como coautor, dado que en la mediación entre el objeto y el público es donde se lleva a cabo el verdadero sentido del FANDSO. Una interacción en la que se construye o reconstruye la obra - depende 
del punto en el que se mire- pero que sin duda le permite al espectador ser participe directo de la imagen, como se aprecia en la instalación de Liliana Porter, Wrinkle Enviorment (1969) (Fig. 1.21) originalmente emplazada en el Museo de Bellas Artes de Caracas, durante la exposición del colectivo latinoamericano.

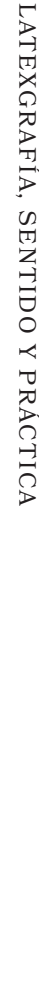

Fig. 1.21. Liliana Porter, Wrinkle Enviorment, Fotocopias arrugadas sobre pared, (1969). Esta instalación cubría la sala completamente e invitaba al público a tomar una de las fotocopias adosadas en la pared, bustos, sillas y demás artefactos, para que se arrugaran y tiraran en los contenedores transparentes dispuestos alrededor del espacio. 
En resumen, el concepto del grabado llevado al objeto del FANDSO implica una reflexión acerca de las prácticas artísticas expandidas y extendidas más allá de los supuestos modernos, conjugando en su quehacer creativo el acto mismo del pensamiento crítico. La creación de estas imágenes se lleva a cabo en la imbricación de sus componentes técnicos y conceptuales, tal y como sucede en nuestra investigación. Los componentes técnicos abarcan una serie de procesos como: impresión, moldeado, corte, doblado, vaciado, o luz, entre otros. En cuanto a su dimensión conceptual se plantean los componentes intercambiables, aleatorios y el llamado "por rebanadas" o "brazo de gitano", a manera de metáfora para ilustrar que un objeto puede fragmentarse o rebanarse en partes como si fuera un plano seriado, ya sea éste un libro, una pasta dentífrica o un embutido, como se observa en la obra de Luis Camnitzer, Topoloǵical Chanǵe of a Word Sequence, (1969/1990) (Fig. 1.22).

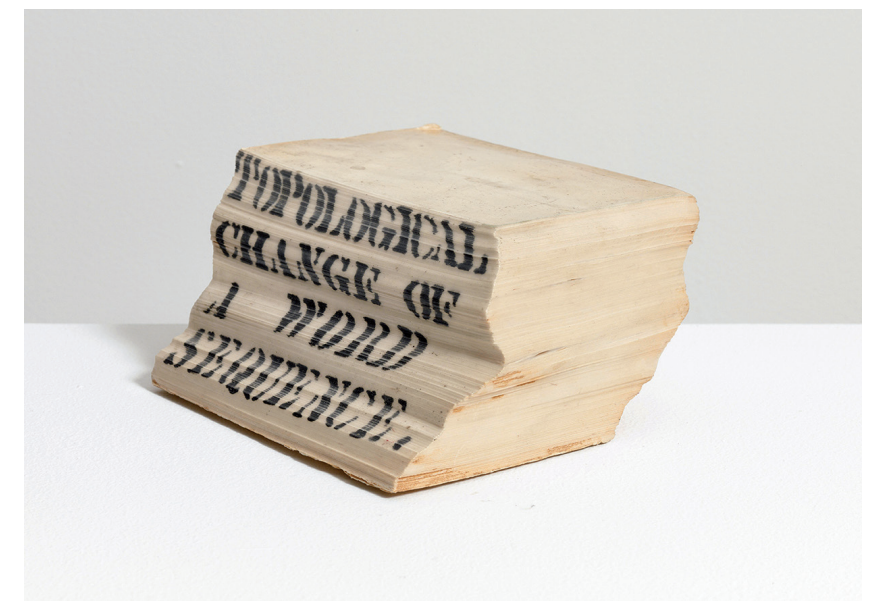

Fig. 1.22. Luis Camnitzer, Topological Change of a Word Sequence, papel, pegamento y marcador. (1969/1990). Este bloque de tarjetas seriadas industrialmente se amontona en lo que es un objeto tridimensional impreso. 
Ahora bien, el otro precedente es el concepto de instalación, que se gestó desde los años ochenta como consecuencia de la expansión llevada a cabo en el campo escultórico y el auge del arte conceptual, bajo las premisas que estableció Rosalind Krauss en 1979 en el reconocido ensayo Sculpture in the Expanded Field. En este texto, según lo apunta su autora, las categorías tradicionales de los campos artísticos, como la pintura y la escultura, sufrieron un giro en el que perdieron su rígida estructura, volviéndose maleables y extraordinariamente flexibles, tanto como para que en dicha extensión pudiera caber casi cualquier cosa (Krauss, 1979). A razón de lo anterior, no se puede hoy desasociar la instalación de las nociones de extensión y expansión, en cuyo sistema interrelacional se da un justo valor al material y al proceso que ocupaba la obra en consecuencia con el discurso y su contenido teórico conceptual, como bien lo apunta Martínez Moro (2018) en su conferencia "Encuentro con el tiempo. Grabado en expansión: espacio y tiempo" en IMPACT 10:

Dentro de toda esta variada y compleja historia de la innovación gráfica, la inercia hacia la expansión espacio-temporal de la obra, que de hecho ostenta por su propia naturaleza divulgativa el grabado y la gráfica, es un factor potencial de experimentación que, desde los años ochenta del siglo pasado, viene dirigiendo el interés del arte contemporáneo, habiéndose incrementado sus fronteras y variantes en los últimos tiempos. (p.26)

Una idea central en nuestro trabajo, ya que el valor in situ, en el que se lleva a cabo la latexgrafía no solo incorpora al público en la recepción de la imagen en el espacio de la exhibición, sino en el centro de su propio proceso de gestación y creación, ya que el contacto --piel con piel-, o, mejor dicho, el trinomio de los cuerpos, espacios y materias, es lo que finalmente queda registrado en las matrices y huellas latexgráficas que se emplazan en la instalación. Consecuentemente con este enfoque, Candiani (2018) se refiere también a la no-especificidad de las prácticas gráficas en el contexto contemporáneo, realzando el valor que aporta la instalación al lenguaje impreso y la interacción con el contexto sociocultural:

Para el pensador y crítico ruso-alemán Borys Groys, el arte de la instalación opera como un reverso de la reproducción. Aplicando sus 
conceptos a nuestro campo, podríamos decir que la instalación extrae el múltiple de su asociación con la reproducción, y lo ubica -aunque sólo sea temporalmente- en el contexto fijo, estable y cerrado de un "aquí y un ahora" topológicamente bien definido. Esto quiere decir que todas las piezas dispuestas en una instalación son originales, por una sencilla razón topológica: hace falta ir a la instalación para poder verlas en contexto. (pp.46-47)

Así, pues: "La gráfica se expande, al igual que se expande el arte, puesto que son uno. Atrás quedaron ya las incisiones entre disciplinas, nos encontramos en un terreno abierto en el que poder transitar" (Gallardo, 2015, p. 97). Transitar, divagar y migrar de un lado al otro, transmutando las veces que sea necesario, para situarnos siempre en la frontera fenomenológica que conjuga e imbrica en vez de dividir. Somos consientes de que seguro habrá otros discursos que no hemos considerado. Sin embargo, se han acotado los antecedentes de la gráfica actual a dos fuentes esenciales, primeramente, el aporte del colectivo The New York Graphic Workshop, en la formulación del objeto del FANDSO, seguido de la invaluable contribución de Rosalind Krauss en función del giro expansivo de los campos y disciplinas artísticas, que confluyen en el concepto de la instalación a partir de la segunda mitad del siglo pasado.

Estos dos pilares, sumados a las prácticas artísticas del cuerpo y las poéticas de la corporeidad en el pensamiento filosófico y sociológico son, sin lugar a dudas, los cimientos que fortalecen y dan un peso teórico al desarrollo, conceptualización y sistematización de la latexgrafía y sus metáforas visuales; las mismas que analizaremos a lo largo de este documento; no sin antes continuar con un breve diálogo con los ejes del discurso artístico contemporáneo de la gráfica interdisciplinar, en el que traeremos a colación una serie de autores que han allanado el camino que hoy nos trae hasta aquí, tanto desde su reflexión teórica como práctica. 


\subsubsection{DESARTICULANDO EL CUERPO DE LA GRÁFICA}

¿Quién puede saber dónde comienza la palma de la mano y cuándo termina el dorso? ¿Hasta qué punto la noción de totalidad del cuerpo no es más que una articulación de fragmentos? Cual si fuéramos un insecto, cuando recorremos visualmente el camino de una línea corporal, nuestra mirada acaba por perderse entre los miles de senderos en que ésta se ramifica. A causa de dicha deriva, lo que creíamos que era el punto de partida, pasa a ser una intersección sin principio ni fin, ni borde ni límite. Así pues, esta experiencia, además de ser una metáfora para ilustrar el sentido de la gráfica que compartimos, es un ejercicio que cotidianamente practicamos en busca de paisajes cutáneos trasfronterizos, tan diversos y cambiantes como los pliegues de la piel.

Del mismo modo que se desdibujan las fronteras entre el cuerpo y sus partes, entre el afuera y el adentro; las divisiones y categorizaciones que históricamente han contenido los ámbitos artísticos en bloques, también se han diversificado intensamente en los últimos años, abriéndose a nuevas experiencias colectivas, en y desde la gráfica contemporánea. Es, precisamente, esta noción inclusiva y rizomática, la que nos atañe cuando hablamos del giro expansivo del grabado y su inherente tendencia a la experimentación y transmutación en el siglo XXI. En consonancia con esta idea de apertura, Garramuño (2015) señala en Mundos en común: ensayos sobre la no especificidad del arte:

En esa minuciosa práctica de desgaste, es posible observar una salida de la especificidad, de lo propio, de la propiedad, y una expansión de los lenguajes artísticos que desborda sus muros y barreras de contención. Y es importante y productivo seguir el recorrido de ese entrecruza- miento de medios y soportes como un discurso en contra de la especificidad de los primeros porque permite desentrañar algunos de los sentidos históricos más importantes de esa apuesta por lo inespecífico en el arte contemporáneo. (p.26)

Por tanto, si abordamos el concepto de grabado en analogía con la noción del cuerpo -antes mencionada-, podemos decir que el sentido de no 
pertenencia a un área específica no conlleva a la negación del ámbito, al igual que la desarticulación de sus partes no excluye el valor de la tradición. El hecho de que, desde nuestro quehacer, migremos de un lado al otro y que los procesos teórico-prácticos se conjuguen mediante componentes que involucran lo performático, el grabado, la escultura o la instalación, nos compromete a mantenernos siempre en un proceso de aprendizaje, y a rodearnos de un equipo interdisciplinario para poder llevar a cabo nuestros proyectos. Este análisis del carácter transicional y no específico de la gráfica de hoy es parte de la indispensable aportación que realiza la artista y asesora internacional, Candiani (2018), en el marco de IMPACT 10, cuando sostiene que:

En el contexto de un arte contemporáneo que se caracteriza por su noespecificidad y no pertenencia, el grabado se ha "desarticulado" de sus propias convenciones en términos de estructuras "auto-diferenciales": técnicas, ediciones, bi-dimesión, matrices e impresión sobre papel, entre otras. En el proceso, algunos artistas utilizan estas "desarticulaciones gráficas" (si podríamos llamarlas así) para generar discursos inesperados, ricos en contenido, cuyas mezclas y saltos son difíciles de categorizar y de definir. Unos construyen la obra a partir del múltiple, otros usan la gráfica como fragmentos sueltos dentro de una práctica más amplia y hay también quienes renuncian a la fisicalidad de su soporte. (p.46)

En nuestro caso, nuestros soportes no pueden ser más carnosos, seguimos la senda de artistas que han conjugado el valor expresivo de la huella corporal como acción performática, para conformar un registro gráfico en torno a la identidad, la memoria y el tiempo, utilizando una serie de estrategias en las que se involucra el cuerpo como vehículo principal y territorio político, ya sea éste a manera de matriz o de soporte, e inclusive como ambos. Es decir, el cuerpo, y propiamente la piel, se convierte en la superficie emisora y receptora de marcas de la acción performática, en la que los límites entre el yo y el otro, el cuerpo y el mundo, se entrecruzan, activando el rol pasivo del soporte y flexibilizando el carácter estático de la matriz. 
En vista de que abordaremos los referentes específicos más en profundidad en los capítulos siguientes, quisiéramos nombrar una serie de artistas para ejemplificar este concepto, al hilo del presente apartado. A principios de la segunda mitad del siglo pasado y como percusores tenemos el caso de Kazuo Shiraga, en la obra Challenging Mud (1955), e Yves Klein, con sus mundialmente conocidas Antropometrías (1960), así como, las no menos importantes, huellas de sangre, en Body tracks (1974) de Ana Mendieta. Más tarde, entrados los años ochenta, destacamos el aporte de Carlos Leppe, en Prueba de artista (1981), quien, con ayuda de Marcelo Mellado, imprimen y reimprimen la palabra "Activo" sobre sus pechos, utilizando una plantilla de papel, un rodillo con tinta y un abrazo, una acción en la que literalmente arriesgaron su pellejo, dado lo subversivo de su propuesta en un contexto políticamente convulso, en el cual era altamente recriminada la homosexualidad, y cualquier manifestación crítica para reivindicar los derechos igualitarios, durante la dictadura de Pinochet en Chile (Fig.1.23).
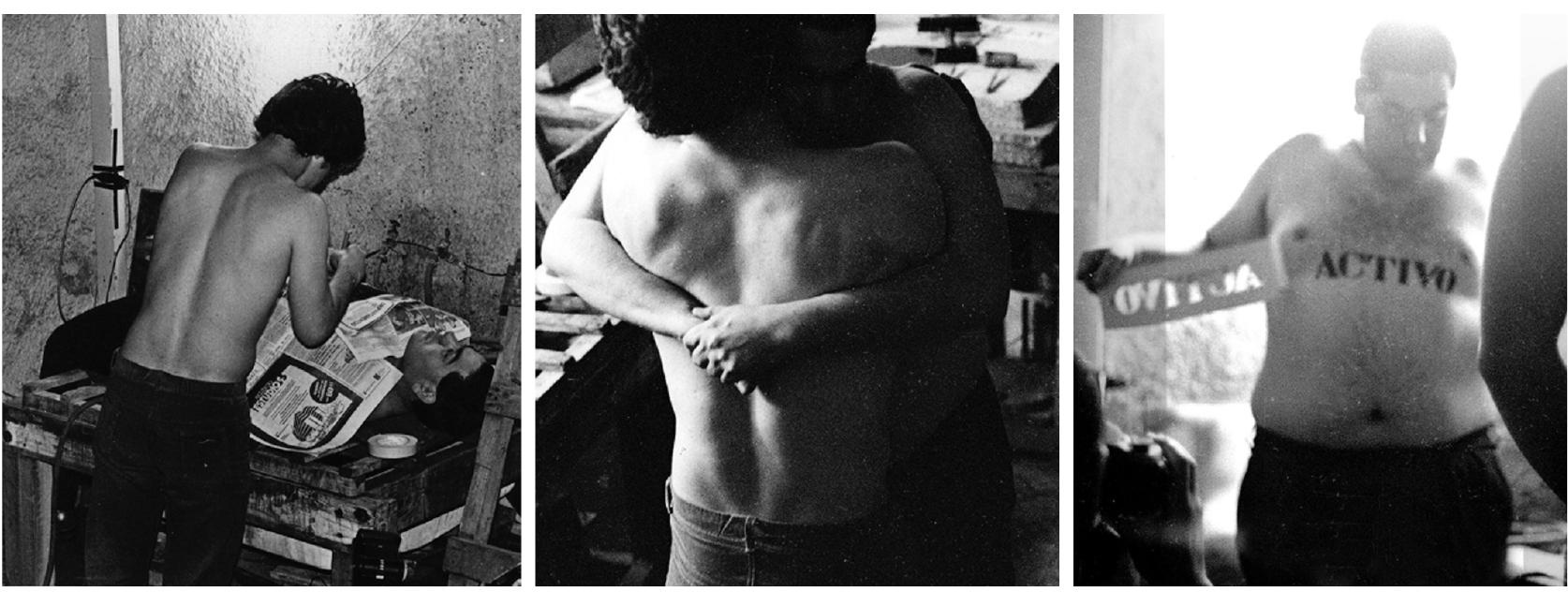

Fig. 3.23. Carlos Leppe, Prueba de artista, acción corporal, 1981 
En el plano centroamericano contamos con la obra de la artista guatemalteca Regina José Galindo, en proyectos como El dolor en un pañuelo (1999) y ¿Quién puede borrar las huellas? (2003), en el primer caso utiliza su cuerpo desnudo para proyectar los titulares de prensa en los que se denuncian violaciones a mujeres, y en el segundo, imprime las huellas de sus pies con sangre en una intervención pública, para evidenciar la desaparición de las víctimas en el genocidio de su país. En el contexto costarricense, destacamos la obra de Sila Chanto, Cadáver exquisito 2009 (Fig. 1.24), una intervención urbana con carácter lúdico en la que la artista convoca al público voluntario a dibujar la silueta de sus cuerpos sobrepuestos en el suelo, frente al Museo de Arte Costarricense, cual si fuera un registro de pruebas forenses, aludiendo la noción de la muerte y la confrontación entre la pasividad del cuerpo en las rígidas estructuras de la sociedad. Más recientemente, las propuestas epidérmicas de Javier Calvo, en DIS (2013), donde utiliza el color de la piel como símbolo para denunciar el racismo que impera en Costa Rica vinculado a los discursos coloniales.

Más cercano a nuestros tiempos, contamos con la instalación titulada 10,141,451 de Tania Bruguera (2019), en la que problematiza la frialdad e invisibilidad del drama humano tras los datos de la migración y sus víctimas, convocando al público a dejar su huella corporal en una superficie sensible al calor y así revelar la imagen oculta que pone rostro a las cifras. También destacamos el corpus de obra de la polaca Zuzanna Dyrda, en proyectos como Brudas (2017), Kindrend (2019) y, más recientemente, Forbidden Touch (2020), en los que utiliza la huella corporal para metaforizar las relaciones humanas y su inherente contacto físico. Así como las acciones performáticas de M.Lohrum, en las que, con medios tan convencionales como el papel y el grafito o carboncillo, redefine las fronteras del dibujo y el rastro corporal, en proyectos como Re-thinking the trace (2019), presentado en Tenerife Espacio de las Artes (TEA) (Fig.1.25). 

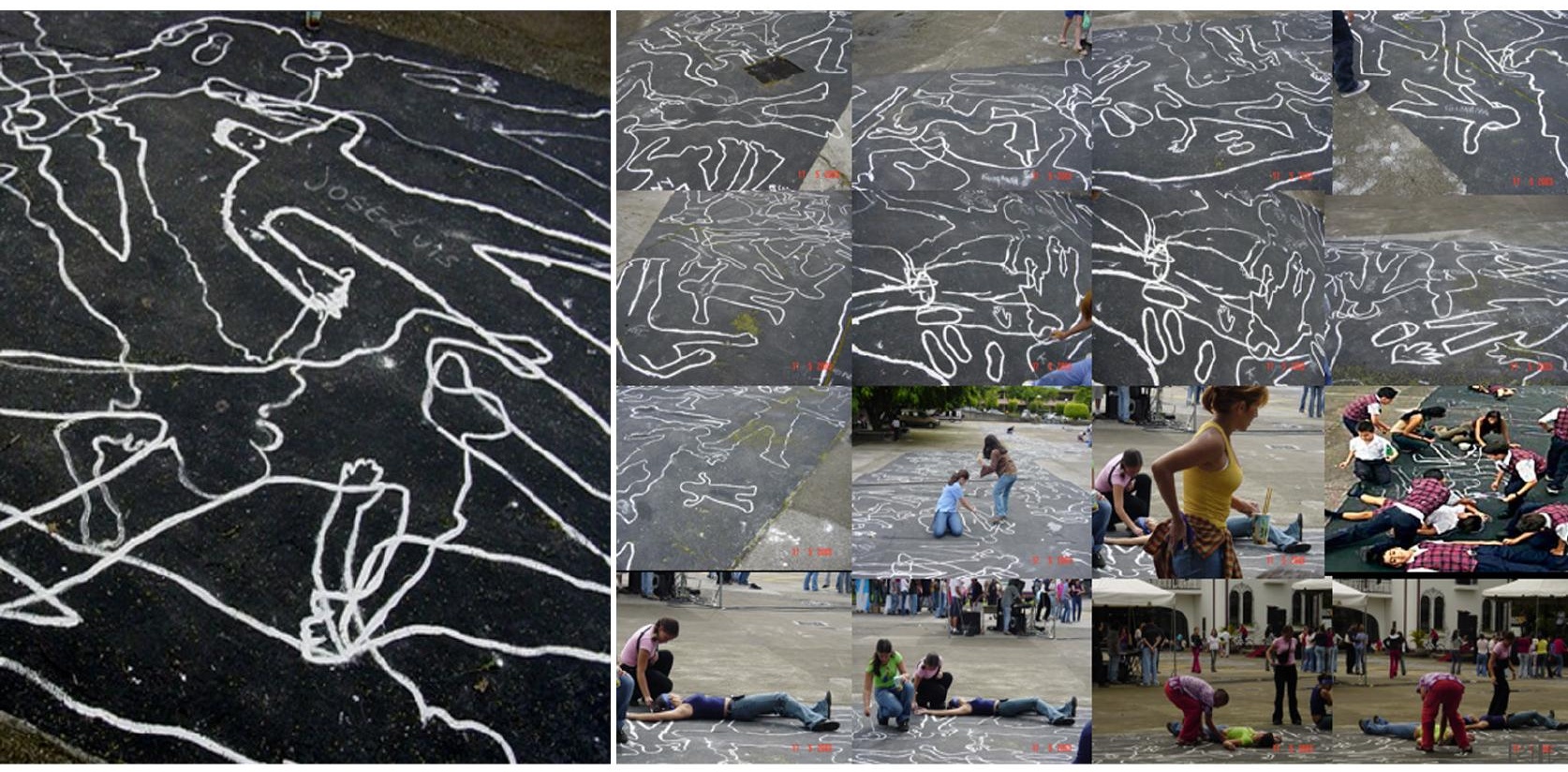

Fig. 1.24. Sila Chanto, Cadáver exquisito,

intervención urbana, 2009

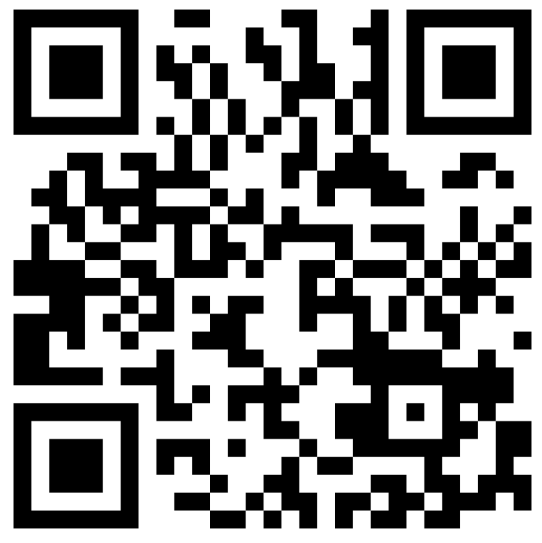

Fig. 1.25. M.Lohrum, Re-thinking the trace, 2019. Escanear este QR la visualizar el vídeo de la artista en donde reúne los procesos de sus obras. 


\subsubsection{EL MESTIZAJE DEL TIEMPO}

En esta revisión hablaremos acerca de dos de los componentes de la expansión gráfica que plantea Martínez Moro (2018): la temporalidad y carácter mestizo, y cómo, ambos, matices se reflejan en nuestra investigación. Más que situarnos en la concepción de la imagen final como producto de un proceso técnico y conceptual, nos centraremos en la dimensión del proceso como parte constituyente de la obra y su prolongación en el tiempo.

Como es sabido, desde nuestro enfoque el cuerpo es considerado la matriz primigenia que está en continuo cambio y transformación, como si fuera una placa de aguafuerte que está sumergida permanentemente en el mordiente, la piel no deja de registrar las líneas del tiempo, desde el día en que somos concebidos hasta nuestra muerte. A razón de esta noción, cada una de nuestras matrices latexgráficas, no son más que pruebas de estado, ya que detenemos en una imagen objetual y flexible, las marcas gráficas que con el tiempo se continuarán acentuando sobre el cuerpo:

El potencial expresivo que ostenta el grabado y los medios de reproducción gráfica no sólo alude a las estrategias masivas de intervención sobre el espacio [...], sino que también puede ser considerado en relación a fenómenos, procesos y hechos relacionados con otras dimensiones, como concretamente el reflejo del tiempo vivido, o de los ritmos propios de la actividad artística. [...] El acto creativo se prolonga así en el tiempo, quedando su solución final desde el primer momento en suspenso, pues la posibilidad de una nueva interpretación, de una nueva intromisión del factor temporal, queda siempre abierta. [...] Desde tal óptica, el grabado está emparentado con aquellas tendencias del arte contemporáneo que se interesan por el proceso por el que atraviesan tanto la materia como las formas en la génesis artística. (Martínez Moro, 2018, p.28)

A propósito de esta idea central, en nuestro proceso creativo la temporalidad no sólo se evidencia en la creación de la matriz, cuando el látex cambia de estado al entrar en contacto con la piel, sino también en la manera en que concebimos las imágenes y composiciones, ya que, en muchas ocasiones, la matriz latexgráfica engendra otra matriz, sobre 
un soporte tridimensional, o bien deja su huella latexgráfica sobre papel, soporte que fragmentamos en módulos y re-articulamos constantemente con el paso de los años. De forma que, algunas de nuestras obras tienen una fecha de inicio, pero no de finalización, como es el caso de Indicios y Digital Archive, que comenzamos en el 2013 y 2018 respectivamente, y a las cuales se han ido sumando piezas y cambiando su composición inicial, hasta concretar su versión expuesta en el marco del proyecto Embodied Memory en e1 2019. Esto sucede, gracias a que desde que iniciamos con la latexgrafía, contamos un acervo de materia prima (matrices latexgráficas y moldes) al cual nos remitimos cada vez que hacemos un nuevo proyecto.

El otro concepto tiene que ver con el mestizaje en el arte contemporáneo. El cual, y según lo introduce en su texto Martínez Moro (2018), ha venido siendo una huella de identidad global en las prácticas artísticas que defienden los idearios interdisciplinarios, transdisiplinarios y multidiciplinarios, donde no se pretende la afiliación a un ámbito específico, sino que se comulga con la universalización de la matriz; un concepto que se deriva, por un lado, por parte de las corrientes del surrealismo, al incorporar técnicas como el frottage, y por el otro, al arte de acción en el que se incorporan elementos de uso cotidiano y soportes alternativos para experimentar los registros, y se le otorga un sentido simbólico al acto de dejar y ser huella.

En términos de nuestra práctica nos sumamos a la idea propuesta anteriormente, e incorporamos su dimensión antropológica, en tanto que el valor de lo mestizo de traslada desde la lectura del cuerpo, y específicamente de su piel, como la superficie simbólica y frontera sociocultural, mediante la cual conjugamos las diversas identidades y los estereotipos ligados a la raza, el género, el color de piel, la política o la religión, bajo un manto democrático y anónimo. Ya que nuestras improntas son fieles testigos de que es más lo que nos une que lo que nos separa, y la memoria gráfica de la piel extendida en un objeto expresivo lo representa. Podemos decir que las características diferenciadoras quedan entramadas en la huella de un común denominador: la diversa y heterogénea condición humana, sólo pudiéndose hacer evidente, el único bien del que nadie escapa: el paso del tiempo. 
Por tanto, si nos vamos al sentido y significado del mestizaje en nuestra práctica, éste conjuga los componentes propios de la migración e hibridación de los discursos del arte contemporáneo con la dimensión ritual que le damos al proceso latexgráfico, mediante el que construimos una comunidad a partir de muchos individuos, provenientes de diversos contextos y culturas, que confluyen en nuestro estudio, dejando una prueba material de su presencia. Así, la gráfica mestiza se identifica con una suerte de mundo imaginado desde nuestra ficción artística, en el que los seres humanos podemos conciliar nuestras diferencias, y ver en la mezcla la riqueza, sin que una categoría o atributo dé paso a un sentido de superioridad de los unos ante los otros.

Considerando que, hoy por hoy, las fronteras son cada vez más fluctuantes, nos acercamos más a lo que Appadurai (2001) concibe como "paisajes étnicos", en los que las comunidades ya no se rigen por una estructura estable, sino por vínculos cambiantes, en los que los rasgos que históricamente han sustentado los ligámenes entre las personas, como el territorio, color de piel, el idioma o la consanguineidad se han extendido en el terreno de lo global y transicional. El ser mestizo, en el imaginario latexgráfico, implica re-conocerse en la huella del otro, inclusive, cuando ese "otro" sea uno mismo, porque la identidad que concebimos como nuestra, es un camino impregnado de huellas de todos los otros que somos y nos conforman (Fig. 1.26). 


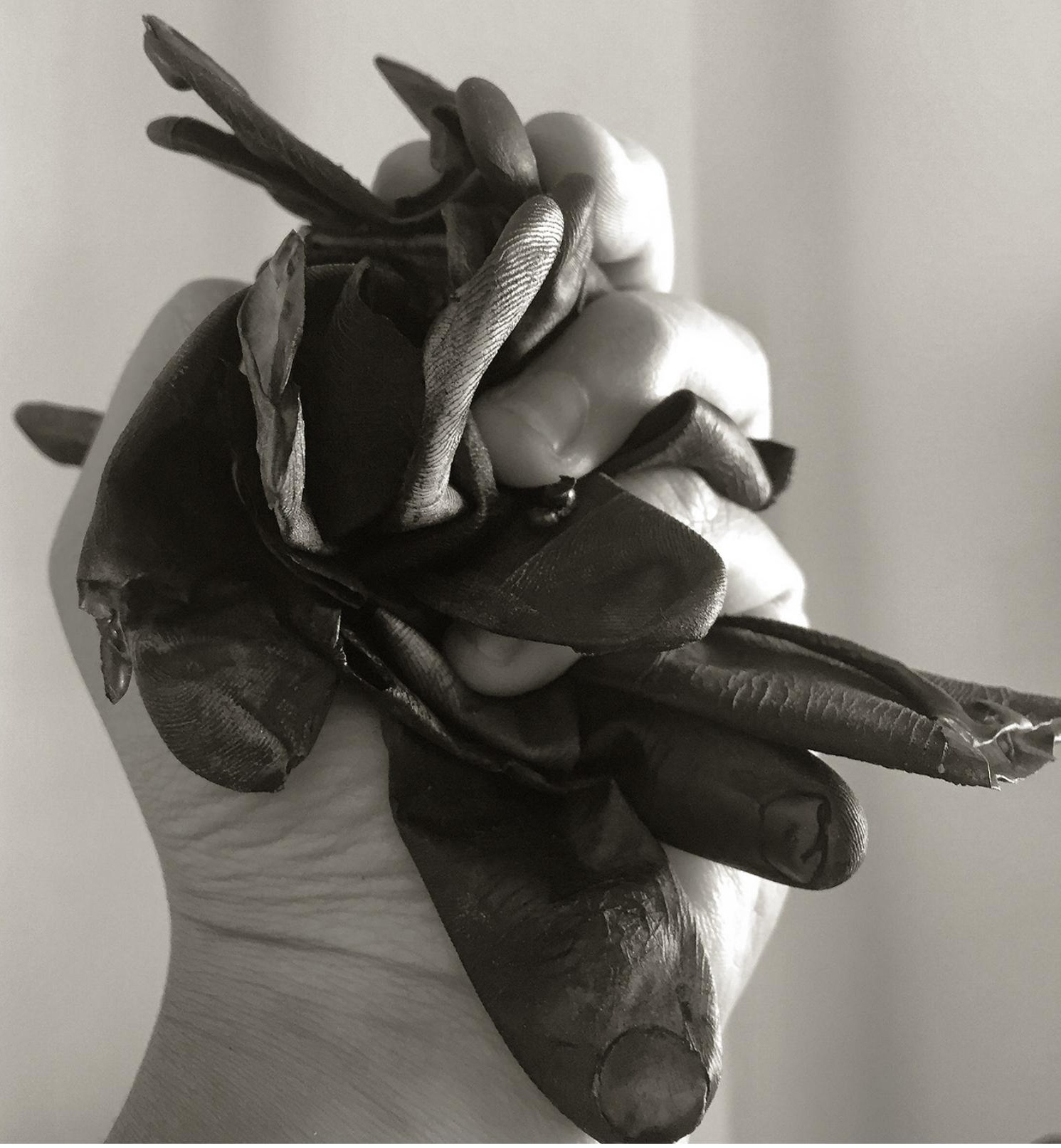

Fig. 1.26. Una imagen muy representativa para nosotros, ya que tomamos en nuestras manos un puñado de fragmentos de dedos de muchas manos anónimas que ha ido recolectando a lo largo de la investigación en diferentes contextos espacio temporales. 


\subsection{APORTES DIFERENCIALES DEL PROCESO LATEXGRÁFICO}

\subsubsection{LA TRANSMUTACIÓN DE LA MATRIZ Y LA HUELLA}

El término "transmutar" viene del latín transmutare, y quiere decir "mudar de una parte a otra", cambiar el estado original para devenir en algo distinto; pero para hacerlo, ha de haber sido algo previamente, y ese "algo", en el marco de nuestro estudio, es lo que denominamos la matriz primigenia, el cuerpo, y más concretamente la piel, en cuya superficie se graban los relatos del tiempo de los que nadie queda exento. Esos relatos representan la memoria gráfica de nuestra vida, la misma que se transmuta en matriz y huella latexgráfica en nuestro trabajo. Desde esta aproximación, la presente tesis problematiza lo que Pelzer-Montada (2019) apunta como el proceso vital del grabado, en otras palabras, la "creación de la matriz", como aquella forma que permite registrar una imagen en un soporte que tiene el potencial para conservarla y perpetuarla mediante la reproducción multioriginal de su huella.

La matriz en el grabado es el punto de partida, y este ha ido variando significativamente con las técnicas a través de la historia, desde lo tangible y matérico hasta lo intangible y virtual; sin embargo, en todos los casos

y en vista de su vertiginosa transformación, podemos considerarla como: "Mapa tomado, como un sistema de signos abstracto que representa de forma muy verosímil, algo real" (Castro Muñiz, 2012, p. 17). Así, este pequeño fragmento condensa la memoria gráfica que simbólicamente nos ayuda a reconstruir la realidad que representa, de una manera abstraída y menos compleja, quizá, o también como una metáfora de la misma. Lo cierto es que, desde este enfoque, el arte es siempre una búsqueda para experimentar la realidad de una manera alternativa, ya sea volviendo complejo lo simple, o simplificando lo complejo.

Sin embargo, este carácter reproductivo que es inherente a la matriz, en nuestro caso sufre un pequeño giro, ya que tiene la capacidad de 
engendrar otra matriz, y así sucesivamente, dadas las características técnicas de la latexgrafía, en la que la misma flexibilidad del material nos sirve para continuar con esta cadena genealógica, desdoblando su huella en superficies bidimensionales y tridimensionales, en los que nuestras matrices son también improntas. Mediante la latexgrafía podemos registrar marcas en relieve o en bajo relieve, es decir, hacemos un grabado reversible, dependiendo del procedimiento que se utilice para obtener las improntas. Por ejemplo, en la huella directa del cuerpo, este transfiere las texturas de la piel por adherencia en el molde de látex, ese al que llamamos matriz latexgráfica, la misma que a su vez puede dejar su impronta en un molde de alginato, en otra matriz de látex, o bien detener esta sucesión de huellas al registrar las marcas en el papel. Este juego dinámico que conjuga la huella y la matriz es lo que expande las posibilidades creativas de la latexgrafía a espacios híbridos entre el performance, el arte corporal, el grabado y la instalación. Pero también hace que el proceso tenga un componente lúdico imprescindible para nosotros y las personas que voluntariamente forman parte de este proyecto.

Dentro de las características más notables que podemos destacar de esta triada: matriz primigenia, matriz latexgráfica y huella latexgráfica, parte primeramente del hecho de la documentación de la piel, acción en la que se crea en una matriz que no sólo registra sus texturas táctiles, sino que emula sus características físicas; en el sentido más amplio, lo que hacemos es desdoblar el cuerpo en una réplica de su muda, para transmutar la huella corporal en un material expresivo, en un trampantojo. En segunda instancia, la matriz se crea en el momento en que el látex líquido natural u otro material moldeante entra en contacto con el cuerpo, y es el tiempo el que cataliza, fragua o solidifica la impronta en un soporte que cambia de estado al mismo tiempo que encarna la huella en su superficie. Por último, y no menos importante es la austeridad mediante la cual se lleva a cabo el proceso, utilizando materiales cotidianos, no tóxicos y al alcance de todos, tanto en términos económicos como procedimentales.

Conceptualizar en torno a la matriz, implica pensar el grabado desde el grabado y con el mismo, para nutrir críticamente el ámbito de nuestro 
estudio, y ampliar sus permeables fronteras; tal y como lo hacemos metafóricamente con la noción del cuerpo. Al desdoblar el cuerpo, expandimos la memoria gráfica encarnada en la huella de la piel, mudamos de un lugar a otro: de la realidad a la ficción artística; ese mundo creativo en el que jugamos con la capacidad de la percepción humana para apreciar lo cotidiano de forma extraordinaria.

\subsubsection{LA POÉTICA DE LA MATERIA}

El valor metafórico que emana de la materia en que está hecha la imagen artística tiene el potencial para captar la atención del espectador y trasladar consigo el significado, que convencionalmente ha sido asociado a ella a lo largo de la historia. Por esta razón, la toma de decisiones dentro del proceso creativo es una declaración de intenciones que posicionan el criterio del productor, ya sea por afiliación o alienación ligado al material y los procesos técnicos, tal como lo expone McEvilley (2007).

Por este motivo, en el presente apartado, nos planteamos ahondar en el potencial poético de la materia y las cualidades intrínsecas para generar contenido dentro del proceso latexgráfico; como bien describe Pallasmaa (2014), parafraseando a Bachelard: "No solo soñamos e imaginamos a través de la forma, ya que nuestra imaginación está engarzada en las sustancias" (p. 57). Partimos de un primer acercamiento donde indagamos las características de las sustancias con las que trabajamos, ya sean estas de origen natural o bien procesadas industriales. Luego medimos su desempeño dentro del proceso creativo e hilamos potenciales lecturas poéticas, procurando no extrapolar este contenido metafórico o realizar interpretaciones forzadas.

Así pues, iniciaremos valorando la piel, esa membrana semipermeable que envuelve nuestra matriz primigenia: el cuerpo. En este tejido se hace visible y tangible la memoria gráfica corporal, que, gracias a varios procedimientos técnicos, hemos transmutado en la huella latexgráfica. La piel, es, por tanto, la base de todo nuestro trabajo. Razón por lo que nos parece oportuno señalar sus propiedades en función del desempeño que 
cumplen dentro del proceso creativo. En la piel hay muchas sustancias, sin embargo, el colágeno, la elastina y la melanina son vinculantes a nuestra práctica. Las primeras dos se encargan de brindar soporte, estructura, resistencia y elasticidad a la piel, y la tercera nos protege de los rayos UV del sol, agregando grosor y pigmento como filtro natural. Estas tres sustancias se van perdiendo con el envejecimiento, causando que la piel se transforme y aparezcan las arrugas, pliegues y manchas, que, desde nuestro enfoque, conforman las líneas del tiempo. En la muda de la piel, se desprende la capa superficial de la epidermis, y en ella, no hay color. Es un tejido elástico, resistente y translúcido.

En función de estas características de la piel y resguardando siempre su integridad física, investigamos una gama de sustancias no tóxicas y procedimientos amigables con el cuerpo, hasta dar con los materiales que utilizamos en el proceso latexgráfico. En primer lugar, hablaremos del látex líquido natural, el cual, y como hemos descrito en sus variables técnicas, proviene de la savia del árbol del caucho, precisamente, al rasgar parte de la corteza que protege el tronco. El látex es manufacturado para ser utilizado en la industria de múltiples maneras, pero es su gran parecido con la epidermis humana la característica que prevalece en nuestro enfoque y en el de otros colegas, como es el caso de la multifacética artista brasileña, Helena Kanaan.

El encuentro con el látex significó un encuentro con Kanaan, quien estaba haciendo una pasantía en la UPV durante sus estudios de doctorado, mientras nosotros invertíamos horas de taller en el período del máster, tratando de dar con la materia prima que hoy da nombre a nuestra técnica. Previo a conocer a Kanaan, habíamos intentado imprimir los moldes de alginato y la silicona, utilizando estos materiales como matriz, sin embrago, como era de esperar, son superficies que repelen los pigmentos, razón por la cual el resultado esperado no fue el mejor. A todo esto, gracias a la experiencia de Kanaan con el látex, fue ella la que nos recomendó hacer pruebas con el mismo, ya que le había dado seguimiento a las variables que estábamos manejando dentro del proceso, y pudo visualizar que el látex podría ser el material que seguro resolvería gran parte de 
nuestros problemas; y así fue. Gracias a su intermediación, dimos con un proveedor de látex líquido natural en Valencia, y comenzamos a realizar las primeras pruebas, las mismas que enseguida resultaron mejor de lo esperado y decantaron en lo que hoy denominamos latexgrafía.

Tanto para Helena como para nosotros, el látex es más que un simple producto para fabricar nuestras imágenes y matrices. Sin él, el contenido poético del proceso y las obras, simplemente no sería el mismo, ya que es desde el valor conceptual y sensorial de las cualidades físicas de esta sustancia, el lugar desde donde ambas partimos para hilar nuestro discurso (Fig.1.27) Así lo expresa, Kanaan (2011) en su tesis doctoral Impressões, acúmulos e rasǵos. Procedimentos litoǵráficos e seus desvíos ${ }^{2}$ :

Observo el látex en su multiplicidad. Una sustancia que ignora contradicciones es líquido y sólido, transparente y opaco, liso y rugoso, frágil y resistente, efímero y duradero. Esa materia prima me proporciona

${ }^{2}$ Véase el texto original en portugués traducido por Luis Diego Muñoz y aprobado por la autora:

Observo o látex na sua multiplicidade. Uma substância que ignora contradições, é líquido e sólido, transparente e opaco, liso e rugoso, frágil e resistente, efêmero e duradou- ro. Essa matéria-prima proporciona-me um fazer instigante, a começar por pensar em sua extração. Algo que visualizo das entranhas, do profundo, do meio das coisas. Do meio das árvores, seiva, fluxo, sistema circulatório. Essa seiva, depois que coagula, adota a temperatura do ambiente, uma temperatura morna, e no toque passo meu calor para ela, e, também, o dos corpos aos quais está em contato. Grava com precisão as impressões das fibras da madeira, da lisura do mármore, das dobras dos plásticos, das digitais da minha mão, em aglomerações sugestivamente sensoriais. Adquire um aspecto carne, pele, vísceras, resgatando a memória de um fluxo que reconhece e recorda quem somos. O látex sei- va se faz carne na fenomenologia das suas qualidades ópticas e táteis. Uma inquietude da matéria orgânica que me desloca e me enfrenta. O látex move-se, percorre caminhos, verte-se em formas-paisagens. Permite inscrições, duplicação, des-locamentos - temporais e espaciais - transformando-se e reformulando-se sempre de novo. O látex move-se, ainda, no sentido de transformação, matéria instável por excelên- cia. Em sua aparência membranosa (o que poderia nos levar a pensar em algo facilmente destrutível) ele é extremamente resistente. Pode ser moldado, espichado, colado. Abarca um paradoxo de estados físicos transitórios, da noite para o dia, da carne à pele, do habitual ao bizarro. A visão da carne interior é, na maior parte das vezes, uma visão de angústia, o inverso da forma humana, a essência do disforme. Uma excessiva semelhança, ou melhor, uma dessemelhança que os corpos látex me provocam. (Kanaan, 2011, p.92) 
una obra estimulante/intrigante, comenzando por pensar en su extracción. Algo que visualizo de las entrañas, de lo profundo, del medio de las cosas. Del medio de los arboles, savia, flujo, sistema circulatorio. Esa savia, después de que coagula, adopta la temperatura del ambiente, una temperatura cálida, y cuando la toco (al tacto) paso mi calor a ella, y también, el de los cuerpos con los que esta en contacto. Graba con precisión las impresiones de las fibras de madera, la suavidad del mármol, de los pliegues de los plásticos, de las huellas digitales de mi mano, en grupos sugestivamente sensoriales. Adquiere un aspecto de carne, piel, vísceras, rescatando la memoria de un flujo que reconoce y recuerda quienes somos. La savia del látex se hace carne en la fenomenología de sus cualidades ópticas y táctiles. Una inquietud de la materia orgánica que me mueve y me enfrenta. El látex se mueve, recorre caminos, se vierte en formas de paisajes. Permite inscripciones, duplicación, desplazamientos temporales y espaciales, transformándose y reformulándose siempre de nuevo. El látex se mueve aún en el sentido de la transformación, materia inestable por excelencia. En su apariencia membranosa (lo que podría llevarnos a pensar en algo fácilmente destructible) él es extremadamente resistente. Puede ser moldeado, estirado, pegado. Abarca una paradoja de estados físicos transitorios de la noche a la mañana, de la carne a la piel, de lo habitual a lo extraño. La visión de la carne interior es, en la mayor parte de las veces, una visión de angustia, el inverso de la forma humana, la esencia de lo informe. Una excesiva similitud, o mejor, una disimilitud que me provocan los cuerpos de látex. (p.92)

Así mismo, los materiales que utilizamos para los moldes del cuerpo: el alginato, la escayola y la silicona, son utilizados en la industria médica, comúnmente encontrados en los depósitos dentales para registrar nítidamente las improntas bucales que sirven para fabricar prótesis e implantes. Tanto el látex como los materiales de los moldes sufren un cambio de estado durante el proceso latexgráfico, en el que la huella de las matrices se registra al cabo del tiempo que tardan las sustancias en catalizarse y fraguar. Esto quiere decir que la impronta es producto de la transferencia por adherencia entre dos superficies que entran en contacto directo, acción en la que se engendra la matriz desde cero. Sin el tiempo, el agua, el aire o el catalizador; el polvo del alginato no se convertiría en esa superficie flexible y humectada, la escayola no se solidificaría en un soporte duro y calcáreo como roca, ni el líquido de la silicona y el látex se convertirían en una membrana elástica, flexible y permeable. 


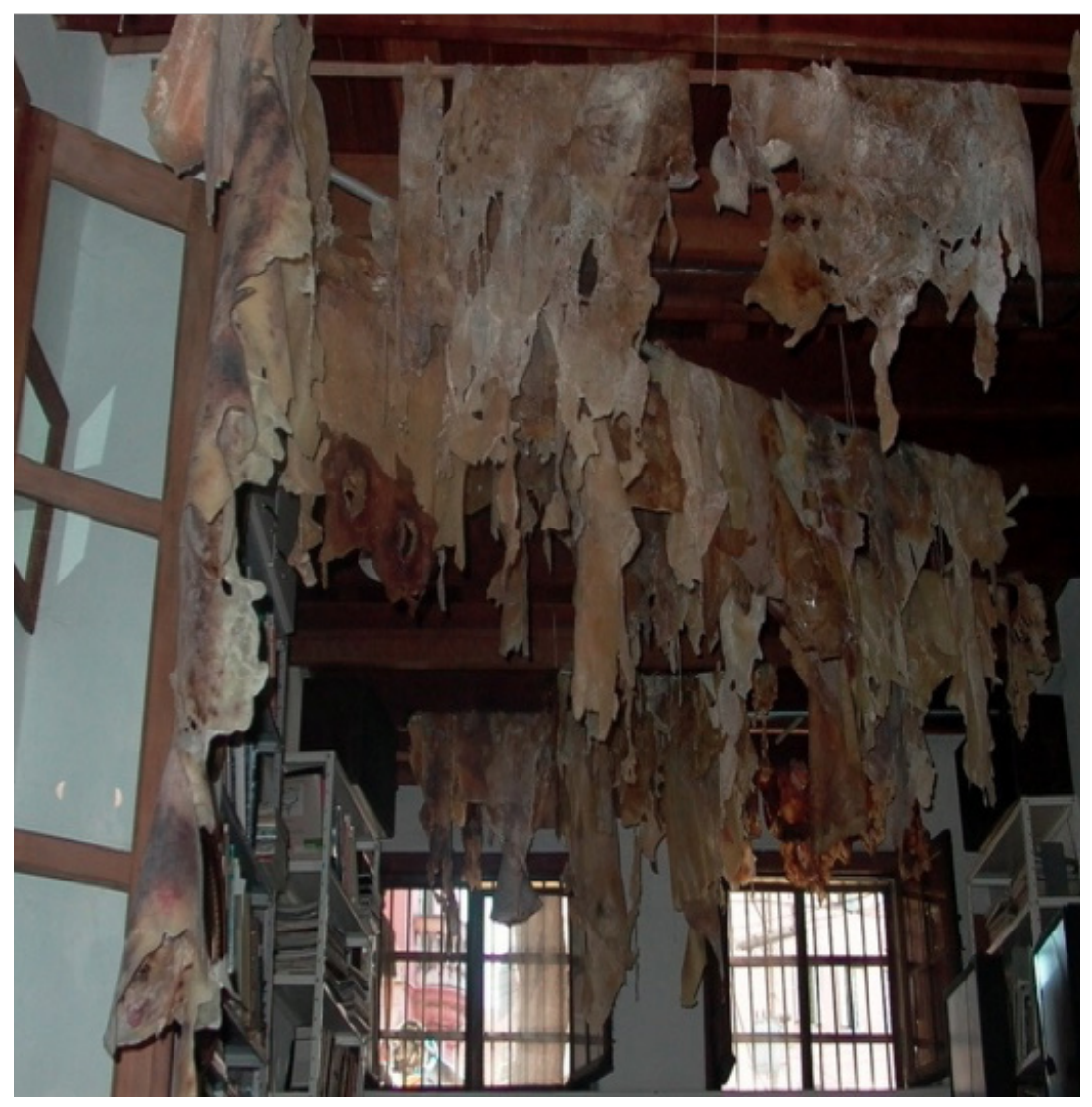

Fig. 1.27. Taller de Helena Kanaan, 2008. Se aprecian los pellejos de látex colgando.

Todos estos materiales sufren una metamorfosis, y este factor es imprescindible en nuestro proceso, dándole un valor agregado al presente estudio, tal y como lo exponemos en el apartado de la transmutación de la matriz y la huella.

Por otra parte, contamos con la tinta y demás implementos del proceso de impresión, que también son de carácter industrial. Por ejemplo, la tinta para sellos de caucho es la sustancia idónea para estampar las huellas latexgráficas sobre el papel gampi. Ha sido inventada para que sea absolutamente compatible con látex y susceptible a la presión ejercida 
manualmente, protegiendo el registro gráfico de la luz y el agua, ya que se utiliza para documentar y archivar marcas que deben quedar nítidas y ser duraderas. En tanto, el valor documental de la huella impresa sobre el papel, cobra una dimensión práctica y se sustenta en el uso cotidiano del pigmento como materia.

En el caso de las esponjas para entintar, estas se utilizan para aplicar maquillaje y difuminar este producto atmosféricamente en cada poro de la piel. Porque, desde nuestro enfoque, las matrices latexgráficas son tratadas como una segunda epidermis. En cuanto al yoga mat, este está fabricado a base de una espuma viscoelástica de alta densidad, hecho que le confiere el nombre de "espuma de memoria", es decir, se adapta a la forma del cuerpo dependiendo de la presión que se ejerza. Este factor ergonómico es fundamental para que hasta el último detalle se transfiera nítidamente de la matriz latexgráfica al soporte del papel y que el molde no se dañe en el proceso. Por último, y no menos importante, el papel gampi, que con su increíble parecido a la membrana de la piel, brinda resistencia y sutileza a nuestras improntas, las cuales pueden ser apreciadas por ambas caras del soporte, ya que es tan fino y ligero que trasluce la huella sin que apenas se note la diferencia. Este papel, es también un producto natural, que ha transformado una fibra como la del gampi, en una suerte de película suave y sedosa, en donde se imprimen nuestras rugosas texturas.

En conclusión, tal y como hemos podido describir brevemente en este apartado, todos y cada uno de los componentes materiales del proceso latexgráfico tienen una razón de ser, emanan un contenido, suponen una serie de criterios que se unen indisolublemente al carácter de nuestras imágenes, y han sido fruto de nuestra exhaustiva y continua investigación a lo largo de los años. 


\subsubsection{EL PROCESO COMO RITO}

Consideramos que el proceso de la latexgrafía tiene una dimensión ritual muy importante, ya que tanto el espacio como el público y el contexto sociocultural adquieren un rol participativo imprescindible en nuestro trabajo, dado que sin su huella -literalmente- no podríamos articular el actual proyecto. Al ampliar las fronteras de la gráfica, la representación simbólica del cuerpo y expandir el taller al espacio público, hemos logrado que la experiencia íntima, en torno a la percepción y experimentación del cuerpo propio que motivó los inicios de latexgrafía, hoy se haya transformado en un lugar de encuentro y contacto colectivo, mediante el cual creamos vínculos para promover inclusivamente la empatía con diversos grupos sociales a través del arte. En consecuencia, nuestras improntas son la prueba material de esta experiencia, en otras palabras, la huella -en todos sus registros- encarna la memoria in situ del proceso colaborativo.

Pero, ¿Qué importancia tiene el sentido ritual en el marco del presente estudio? Para atender este cuestionamiento nos apoyamos en el enfoque que plantea el filósofo surcoreano Byung-Chul Han, autor de La desaparición de los rituales (2020), donde expone que los rituales son hacedores de una serie de valores y signos que dan sentido de pertenencia a los individuos a través de su repetición a lo largo del tiempo; por consiguiente, el ritual dota de imágenes y metáforas a las personas en la construcción de su identidad dentro del tejido social, modelando la percepción simbólica del mundo y de sí mismos. Al contrario de lo que sucede en nuestro frenético ritmo de vida, donde pasan desapercibidos los pequeños detalles cotidianos; en la repetición ritual se establece un espacio estable y desacelerado en el que se aprecia la fluidez de las cosas en tiempo real. Un espacio enraizado en la materia y la corporalidad. Así lo acota él cuando nos dice que: "La repetición como reconocimiento es por tanto una forma de cierre. Pasado y futuro se fusionan en un presente vivo" (Ibidem, p.20). 
La noción de repetición que plantea Han, y con la cual comulgamos absolutamente, no implica lo serial ni rutinario, ya que, si percibimos nuestro proceso como ritual técnico nos ayuda a estabilizar y sistematizar las etapas siguiendo un orden establecido y dejando la puerta abierta a los hallazgos experimentales, sin que una cosa desvirtúe la otra. Lo anterior se refrenda desde nuestra experiencia, ya que a pesar de venir repitiendo el proceso latexgráfico desde hace ya más de una década, no ha habido un sólo día en que no ocurra algo distinto, afrontando creativamente los nuevos retos y problemas plásticos; e incorporando en nuestra investigación la retroalimentación constante del público. Esta noción del arte como proceso continuo de aprendizaje permite que disfrutemos nuestras jornadas y talleres de una manera más intensa y abierta, ya que sabemos que no habrá nunca dos matrices latexgráficas iguales, y sus huellas no dejarán un registro idéntico a la anterior, siendo estas variables una característica fundamental en nuestro trabajo, tal como lo expone Evangelio (2019) en "Embodied memory, a trace expressing the truth of Priscilla Romero" ${ }^{3}$ :

Esto de algún modo contrasta con lo que muchos estudiosos han mantenido en cuanto a que la característica definitoria del grabado es su carácter de obra múltiple, capaz de generar muchas copias exactas. Todavía hoy persiste de forma amplia esa idea, que, a nuestro parecer, se sustenta en dos apreciaciones erróneas: una, lo que se genera por medio del grabado y la estampación no son copias, y dos, los ejemplares obtenidos a partir de una matriz no tienen por qué ser necesariamente iguales (p.66)

Desde este punto de vista, la singularidad del multioriginal que aporta

\footnotetext{
${ }^{3}$ Este texto fue originalmente escrito en castellano, pero ha sido publicado en inglés según consta en la referencia bibliográfica, a continuación, la cita:

In a certain way, it contrasts with the opinion held by many scientists, namely that a distinct feature of printmaking is its multifunctionality making possible generating of multiple, exact copies. This idea has been sustained to this day. However, in our opinion, it is based on two erroneous assessments. Firstly, artworks produced with the use of printmaking are not copies, and secondly, copies obtained from one matrix do not have to be necessarily identical (Evangelio, 2019, p.66)
} 
cada una de nuestras improntas es producto del proceso latexgráfico y su participación abierta al público, así como al carácter cambiante de la piel. Para fortalecer esta idea, traemos a colación la reflexión que realiza Nancy (2014), donde apunta que el arte en esencia puede ser llamado "repetición" dado que reproduce algo que previamente está dado en otro registro, sea éste una forma, materia o un cuerpo, entre otros, razón por la que lo único y lo múltiple se imbrican, y la singularidad del objeto artístico no queda exenta de su multiplicación. Esto, llevado a nuestro campo, implica que en la repetición del proceso latexgráfico se obtienen siempre pruebas de estado de un cuerpo que emite una huella, dado que nuestra condición viva supone una variabilidad constante que se transfiere en las improntas y se comparten en los talleres, espacios donde se documenta gráficamente la expresión corporal de nuestros voluntarios: "De este modo, los rituales generan un saber corporizado y una memoria corpórea, una identidad corporizada, una compenetración corporal” (Han, 2020, p. 23).

Esta perspectiva se sostiene también por autores como Colombres (2004) quien destaca que el rito se conforma en la acción corporal que expresa el pensamiento. De esta manera, el rito está ligado a un espacio específico en el que se lleva a cabo una actividad compartida por un grupo y liderada por una figura de poder. En nuestro caso, el poder recae en la figura de la artista, que ejerce el papel de creadora y docente para difundir las características de la técnica y ganarse la confianza de los colaboradores. Creemos fielmente en que el público informado puede tener una mayor empatía en el proceso, y así ceder voluntariamente una huella de su cuerpo; hecho que no deja de tener un rol de poder, tanto de parte de la artista para persuadir a sus oyentes como de estos para decidir si participan activamente o no. Quizá, este enfoque nos recuerda esa mística que en contextos ancestrales lideró la experiencia de lo que hoy podemos llamar arte, y lo que en el plano de nuestro trabajo se comprende a través de la huella corporal como acción performática participativa.

A esta delicada línea entre el poder de convencimiento y el liderazgo, se refiere la crítica Pelzer-Montada (2019) al respecto de nuestra práctica, cuando señala 
que: "Tomar una huella de otra persona, tan inofensiva como la huella de un dedo o un codo, es un ejercicio de poder (simbólico), de ahí la necesaria delicadeza y sensibilidad por parte del artista" ${ }^{4}$ (p. 93). Ahora bien, esa preciada impronta corporal es gestionada por nosotros, pero hemos de destacar que quienes ejecutan el proceso son las personas. Este pequeño giro tiene un valor simbólico interesante, ya que, en la muda simbólica de esa piel de látex, son los propios individuos quienes se autodespellejan y posteriormente imprimen con tinta la huella latexgráfica sobre papel, para finalmente donar -como ofrenda- ese fragmento material que da constancia de su presencia.

Pero más allá de la memoria material que puede ligarse a determinadas formas o registros, quizá lo que le da más fuerza ritual a nuestra labor sea precisamente lo intangible e inaprensible que acontece en cada jornada de recogida de huellas. Esos vínculos personales que en ocasiones son fugaces y en otros momentos han sido la llave de una amistad. Dejar una huella no es un acto superfluo, por simple que parezca, tiene, para nosotros, un significado profundo que yace a flor de piel. Detrás de cada impronta hay una historia de vida, un relato gráfico encriptado en las marcas de la epidermis. Cada matriz latexgráfica es una prueba de estado de un fragmento del cuerpo de alguien con quien hemos coincidido y que a lo mejor no nos volvemos a encontrar, pero que en los 15 minutos que duró el látex en secar, esa persona confió en nosotros, para entregarnos un registro material de su identidad. Esta ofrenda y condescendencia nos llena de energía, y le da un sentido vivo a este proceso, al que catalogamos como rito latexgráfico.

\footnotetext{
${ }^{4}$ Texto original fue escrito y publicado en inglés. Para efectos de la presente tesis, Priscilla Romero ha realizado la traducción de la siguiente cita:

"Taking an imprint from another person, even as innocuous as a finger or elbow print, is an exercise of (symbolic) power, hence the necessary delicacy, sensitivity on part of the artist" (Pelzer-Montada, 2019, p.93)
} 


\subsubsection{DE LA EXPANSIÓN GRÁFICA A LA EXTENSIÓN SOCIO COMUNITARIA}

Cuando el trabajo de campo se convierte en el campo de trabajo, es porque el proceso creativo se afianza al contexto en el que participamos. En nuestra investigación somos conscientes de la responsabilidad social que tienen las entidades educativas y sus actores, para promover la transformación cultural mediante la educación artística, dentro y fuera de las aulas. Así establecemos vínculos entre la sociedad y las investigaciones que se llevan a cabo en el marco universitario, incorporando los aportes que la práctica extensionista revierte a nuestro ámbito de estudios, en un ciclo de aprendizaje recíproco en el que las experiencias vivenciales trascienden las páginas de esta tesis y certeramente no podemos trascribir - en la totalidad de su riqueza - en palabras.

Este enfoque comunitario de la gráfica como "acción performática" colaborativa, también es tomado en cuenta en la reflexión en torno a nuestro trabajo que realiza la presidenta de la Trienal de Grabado Internacional de Cracovia, Raczek-Karcz (2019) en el texto "Embodied traces of memory" ${ }^{5}$, donde apunta que:

Al trasladar este concepto de la lingüística al área del grabado de Priscilla Romero, por analogía podemos decir que el proceso de creación de la matriz no sólo es el desarrollo del instrumento utilizado para imprimir

\footnotetext{
${ }^{5}$ Este texto fue escrito y publicado en inglés. Para efectos de esta tesis, Priscilla Romero ha realizado la traducción al castellano de la cita: Translating this linguistic concept into the area of printmaking used by Priscilla Romero we can by analogy say that the process of creation of a matrix is not only development of a tool used to print consecutive works, but also an activity involving a specific group of people cooperating with the artist, who in this way co-create an expression, which is also an activity building a kind of community, resulting in production of specific works, which bond together the people cooperating in this process forever. The main feature of all installations is the identity of participants symbolized by this type of trace, which constitutes a materially (and visually) defined imprint of a person - his or her fingerprints. (Raczek-Karcz, 2019, p.38)
} 
consecutivamente el trabajo, sino también la actividad que envuelve específicamente a un grupo de personas que colaboran con la artista, quienes co-crean una expresión conjunta, que es a su vez la actividad para construir un tipo de comunidad, cuyo resultado es un trabajo específico, mediante el cual se vincularán los participantes por siempre. La principal característica de todas las instalaciones es la identidad de los colaboradores simbolizada en este tipo de rastro, que constituye materialmente (y visualmente) la impronta de una persona - su huella de identidad. (p.38)

Así, cada huella representa un contacto humano, una relación que se ha forjado desde las entrañas de la técnica como vehículo, para construir una comunidad que se forja en el ritual latexgráfico. Desde que finalizamos nuestros estudios de máster, hemos impartido muchos talleres y charlas para dar a conocer la técnica de la latexgrafía y reflexionar en torno a las poéticas del cuerpo, desde la gráfica contemporánea y los espacios de interacción comunitaria. En nuestra opinión todos los contextos son igualmente importantes, ya sean de carácter académico, ferias o talleres infantiles.

Cada uno de estos públicos nos brindan un punto de vista distinto que enriquece nuestra perspectiva inclusivamente. Entre los múltiples contextos quisiéramos puntualizar aquellos que por sus características son especialmente significativos para el marco de esta tesis, como los siguientes: Appalachian State University, Carolina del Norte, Estados Unidos (2012), Festival Internacional de Grabado y Arte sobre Papel/ FIG-Bilbao y Trans Europe Halls-Bilbao, País Vasco, España (2018), Falla Visitación del Barrio de la Zaidía en Valencia, España (2019) y el Museo de Arte Moderno de Bydgoszcz, Polonia (2019-2020). A continuación, una breve descripción de estos eventos y su incalculable repercusión en el presente estudio: 
A principios del 2012, y apenas un año después de concluir nuestros estudios de máster en la UPV, fuimos contactados por los profesores Garner Dewey y Scott Ludwing, quienes junto a sus estudiantes emprendieron una gira a Costa Rica como parte de los programas de intercambios internacionales de ASU. Como resultado de este encuentro, que tuvo lugar en la Universidad Nacional, la entidad norteamericana nos invita a impartir una serie de talleres y charlas para enriquecer los contenidos del curso de grabado y fotografía con una propuesta innovadora y experimental como la latexgrafía. Durante nuestra estancia emprendimos un proyecto colectivo que partió de una puesta en contexto de la gráfica expandida desde América Latina y los procesos técnico-discursivos que en nuestra maestría habíamos desarrollado. Posteriormente, realizamos talleres prácticos en los que las personas participantes hicieron sus propias matrices latexgráficas e imprimieron las respectivas huellas sobre papel. Como resultado de estas jornadas creamos una obra conjunta denominada Fraǵmentos Siónificantes (2012), la cual fue expuesta en la galería de ASU (Fig. 1.28).

Sin lugar a dudas esta corta estancia rindió frutos a corto y medio plazo, ya que además de haber sido nuestro primer encuentro internacional, nos dio la confianza necesaria para seguir adelante. Además, pudimos indagar acerca de los distintos materiales que el mercado estadounidense oferta para nuestro proceso, y fue ahí donde encontramos la marca Holde's Latex, la cual ha sido nuestro principal proveedor de suministros a lo largo de una década, dada la inmejorable calidad de sus productos. Sin embargo, al margen del magnífico látex que conseguimos, realizamos todo el proceso íntegramente como lo habíamos iniciado en Valencia, es decir, con instrumentos austeros y enteramente a mano.

Este factor handy (a mano) y low cost (bajo costo), llamó mucho la atención 

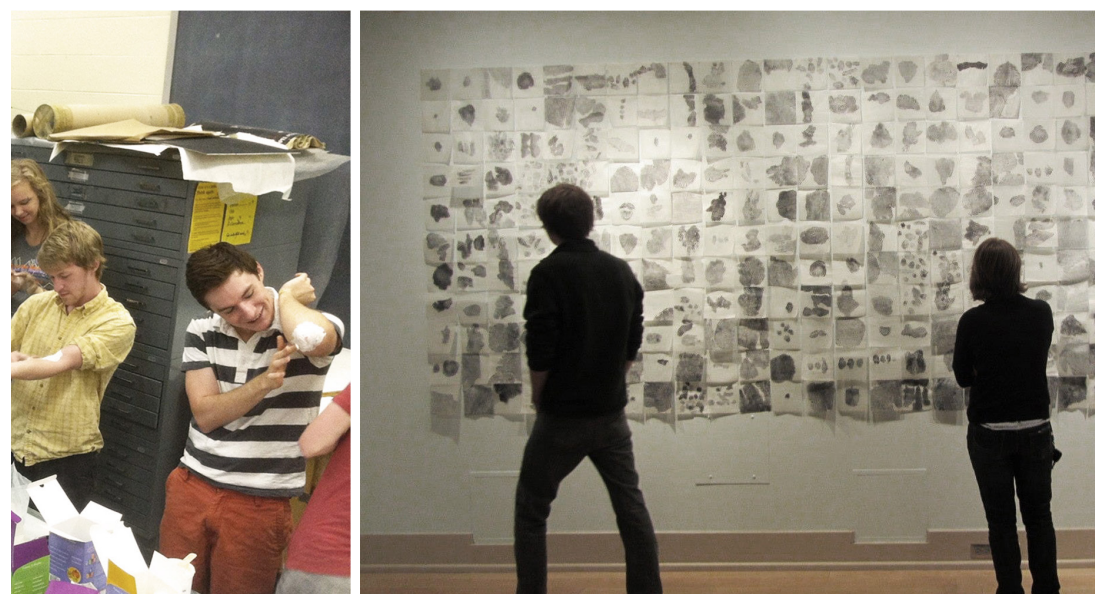

Fig.1.28. Talleres con los estudiantes de grabado de ASU y el proyecto colectivo resultante de los talleres Fraǵmentos siónificantes, 2012. Latexgrafía sobre papel gampi.

del público estadounidense, ya que pudieron comprobar que no hace falta un equipo de alta tecnología y materiales excelsos para producir una obra con identidad y calidad. Cada estudiante y docente dejó literalmente su huella en este trabajo, la misma que gracias a su carácter reproducible, imprimimos múltiplemente para conformar el mural, que al cabo de la muestra fue repartido entre sus ejecutores, quienes nos donaron tanto su matriz latexgráfica como su respectiva impronta bidimensional.

Las huellas latexgráficas que pertenecían a este ejercicio académico fueron reutilizadas y recompuestas en la obra Macro 432, (2017) (Fig.1.29), la cual formó parte de varias exposiciones, dentro de las que se encuentra IMPACT 10 (2018), Embodied Memory (2019) y Valoarte (2021). Este recurso es una costumbre que tenemos al abordar procesos llevados a lo largo del tiempo, brindándole siempre la oportunidad de generar nuevas imágenes a partir de las anteriores. Esta experiencia internacional continúo en el 2013, cuando regresamos a ASU, pero en esta ocasión para impartir un semestre completo como docentes, gracias a la excelente relación que se forjó un año antes. Así, nuestro proyecto fue cogiendo forma y continúa migrando con nosotros de un lugar a otro; y en cada sitio que hemos podido seguimos recolectando huellas; improntas en las que materialmente se registra el encuentro y el contacto humano gracias al arte. 

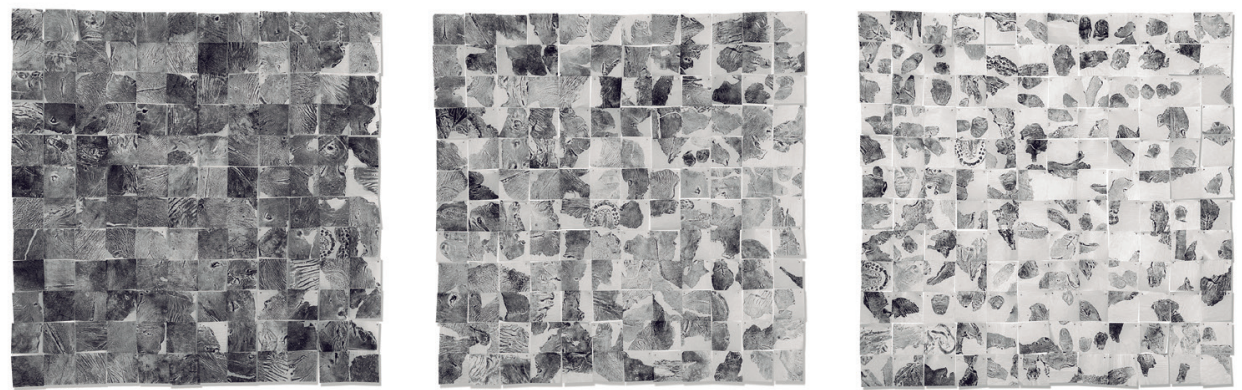

Fig.1.29. Priscilla Romero, Macro 432, latexgrafía sobre papel gampi. 60x60cm cada bloque. Esta imagen se originó en el 2017, a partir de las impresiones de Fraǵmentos Siǵnificantes (2012), imagen resultante de los talleres impartidos en ASU.

\section{FESTIVAL INTERNACIONAL DE GRABADO Y ARTE SOBRE PAPEL (FIG-BILBAO) Y TRANS EUROPE HALLS-BILBAO (TEH85), PAÍS VASCO, ESPAÑA, 2018}

En el marco del open portafolio de FIG tuvimos la oportunidad de difundir nuestro trabajo como parte de los galardonados (Fig.1.30). Esta plataforma sirvió para compartir con colegas del mundo del grabado contemporáneo y los amantes del arte que se acercaron al evento. A diferencia de los talleres de ASU, en donde se extendió nuestra práctica por dos semanas como parte de una actividad académica, en esta ocasión fue una jornada intensa en la que presentamos la obra Entreabierto (2017) e Indicios (2013), de cara al público durante un día, explicando su proceso creativo y principales reflexiones discursivas en torno a la latexgrafía.

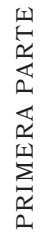




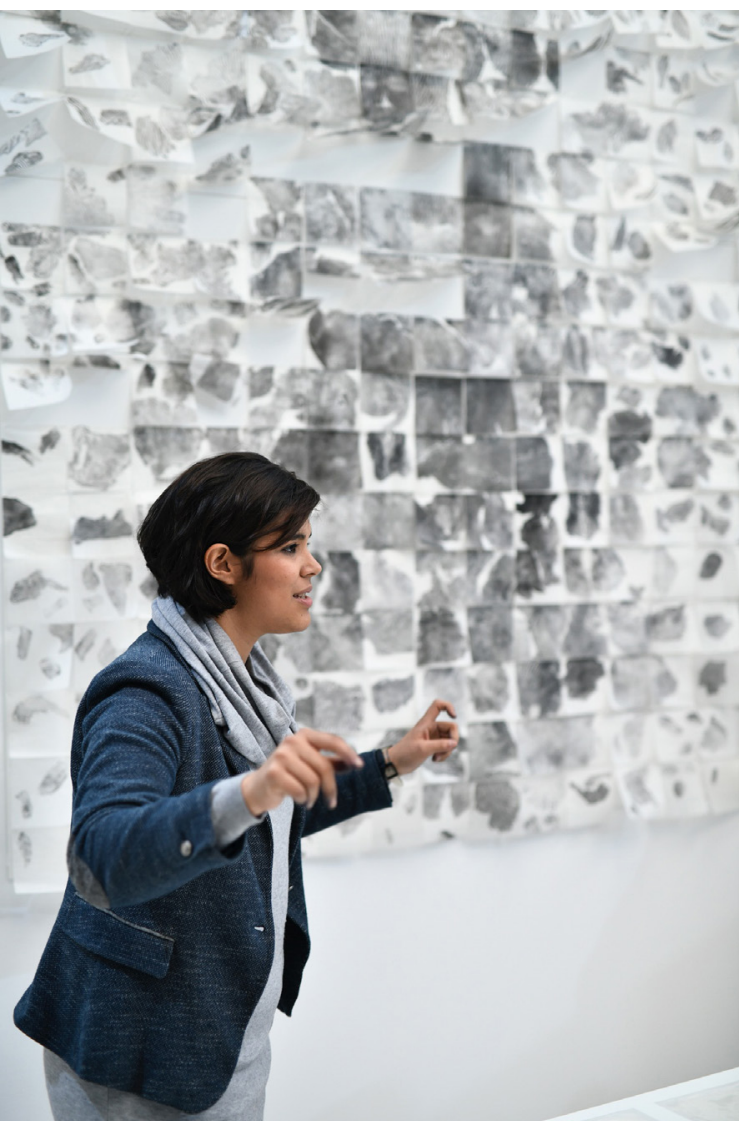

Fig.1.30. Imágenes de nuestra participación en FIG, al fondo de obra Entreabierto, latexgrafía sobre papel gampi, $240 \mathrm{~cm} \times 240 \mathrm{~cm},(2017)$

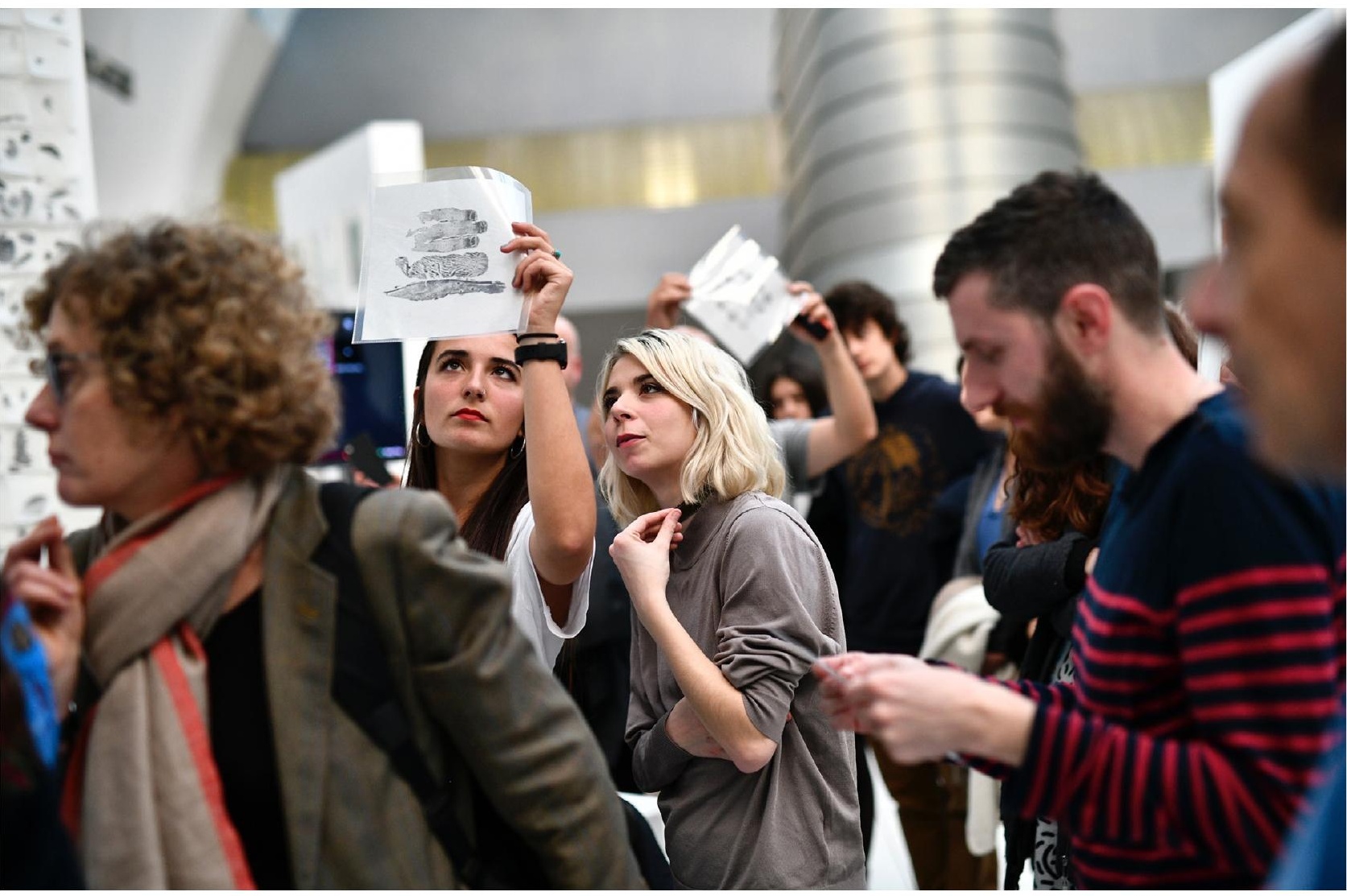


Fue gracias a esta coyuntura que ideamos la posibilidad de realizar demostraciones técnicas a pequeña escala en donde la audiencia pudiera sacar una matriz latexgráfica de su dedo e imprimirlo, mientras nosotros proyectamos un video del proceso y atendimos preguntas. Durante nuestra participación en FIG, fuimos contactados personalmente por Manuel Gómez-Álvarez, creador de ZAWP (Zorrotzaurre Art Work in Progress) y presidente de la Asociación Cultural Haceria Arteak, quien empatiza con nuestro proyecto y nos invita a ser parte de Trans Europe Halls 85 (TEH) congreso internacional que albergó ZAWP y La Hacería, ese mismo año, en las naves industriales contiguo a la Ribera de Deusto y Zorrozaurre, en la ciudad de Bilbao.

En el congreso emprendimos un trabajo titánico, al coordinar el registro, impresión y montaje de 225 personas quienes conformaron el mural de TEH85, un símbolo gráfico del manifiesto del evento, en donde cada quien, en vez de firmar con su nombre, dejaba impresa su huella latexgráfica y donaba el molde a nuestra colección. Sin percatarnos del alcance que llegaría a tener esta actividad, llegamos a reunir improntas de personas de más de 20 nacionalidades distintas en un lugar de encuentro cultural (Fig.1.31). Así, se sembró la semilla de lo que es el proyecto Digíital Archive, el cual se inició en el 2018, fue expuesto en el 2019 y continuará creciendo a lo largo de nuestra carrera artística.

Como es de esperar, un proyecto de esta envergadura no se pudo haber llevado a cabo únicamente por nosotros, sino que contamos con la preciada ayuda de las pasantes de ZAWP, Mona Westman y Sofía Moreno, a quienes capacitamos instrumentalmente para que pudieran trabajar hombro a hombro con nosotras. Además de haber sido un éxito como proyecto, dejar abiertas las puertas a una obra comunitaria, el impacto de FIG y TEH85 en nuestra investigación es incalculable, ya que la máster Moreno, se convirtió en nuestra mano derecha en la ejecución del corpus de obra para la exposición Embodied Memory, acompañándonos en todo el proceso de producción en Valencia y montaje en Polonia. 


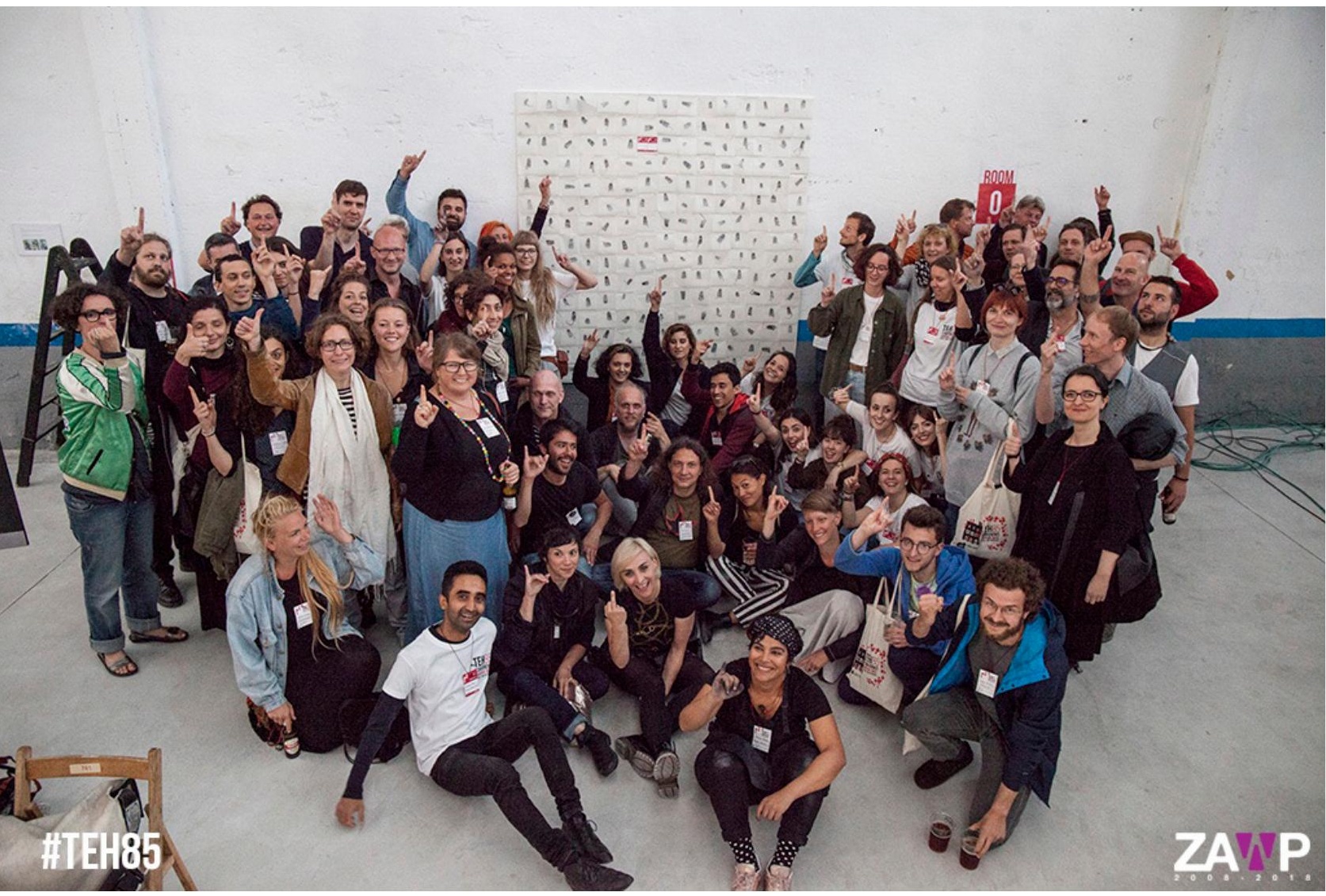

Fig.1.31. Fotografía de un grupo de participantes de TEH85, mostrando el dedo que registraron y al fondo la imagen mural compuesta con la huella latexgráfica de cada una de las 225 personas. Al término del evento, cada quien se llevó la impresión y donó su molde a nuestra colección. 


\section{FALLA VISITACIÓN, LA ZAIDÍA, VALENCIA, ESPAÑA (2019)}

El barrio de la Zaidía fue el centro de operaciones del presente proyecto por 4 años; lugar que nos acogió e hizo sentir como en casa; motivo por el cual en el contexto de las fallas del 2019 fuimos invitados por la Asociación de Comerciantes de la Zaidía, a participar en las actividades infantiles para integrarles en el quehacer artístico. De esta manera, pudimos recolectar muchas matrices latexgráficas y comprobar que nuestro proceso técnico
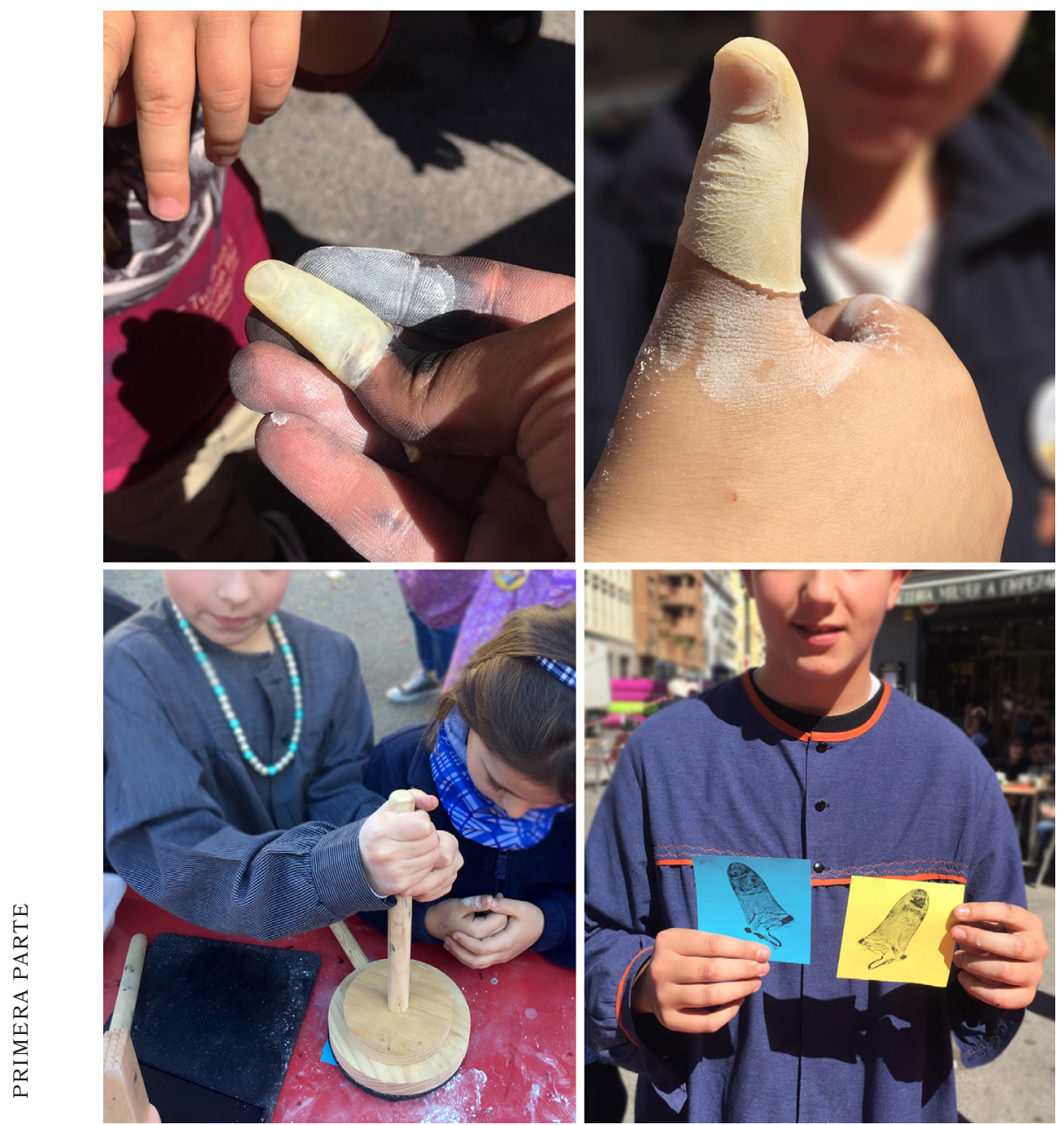

Fig.1.32. Algunas muestras del taller llevado a cabo con la comunidad infantil de la Falla Visitación en el espacio público, Valencia, España, 2019. 
estaba al alcance de todos, ya que los participantes oscilaban entre los 4 y los 15 años. Este grupo de menores realizaron sus moldes, los despegaron de la piel e imprimieron sobre papeles de colores que se llevaron como recuerdo de este encuentro. El hecho de que el proceso haya sido íntegramente ejecutado por la comunidad infantil ha sido un aliciente importante, ya que pudimos comunicar las etapas de la técnica latexgráfica de una manera simple y práctica, y corroboramos que, con la ayuda de instrumentos de fabricación casera y de bajo costo, podríamos validar la calidad del proceso sin que hiciera falta más que los materiales básicos de la técnica, muchas ganas de pasarlo bien y ensuciarse las manos (Fig.1.32)

\section{MUSEO DE ARTE MODERNO DE BYDGOSZCZ, POLONIA, (MOB), 2019.}

Los talleres que se impartieron en el MOB, fueron en coordinación con el departamento de educación de esta institución. A razón del premio otorgado en la Trienal Internacional de Grabado de Cracovia en el 2018, pudimos llevar a cabo la muestra individual Embodied Memory, la cual fue enteramente financiada por la fundación Leona Wyczółkowskiegoo. Para nosotros fue un honor y también una gran responsabilidad, ya que en esa misma sala de exhibición se han realizado exposiciones monográficas de artistas mundialmente conocidos, como Durero, Rembrandt y Goya, así como un gran número de artistas gráficos polacos contemporáneos. Motivo por el cual, decidimos desde el primer momento que nuestro proyecto tendría que imbricar el contexto, su gente y su historia, para que la propuesta tuviera una identidad propia y sentido en su marco sociocultural.

Al concluir la ceremonia de inauguración de la trienal nos dirigimos a la ciudad de Bydgoszcz para conocer más a fondo su realidad, el espacio y el equipo de trabajo con quienes desarrollamos nuestro proyecto. Ese gesto llenó de ilusión a los polacos, ya que se sentían parte de una muestra que no sólo albergaría arte contemporáneo, sino que serían ellos los actores 
principales de la misma. Para cumplir con este objetivo nos empapamos de su historia y planteamos una serie de talleres que se realizaron unos meses después, en los que convocamos al público partiendo de lo interno a lo externo. Es decir, iniciamos con el personal del MOB. Posteriormente, convocamos a colegios, escuelas, estudiantes de artes y público en general, dentro de los que destacamos la grata participación del grupo Dzieciece Graffiti, conformado por personas de diversas edades con síndrome de Down y síndrome del Espectro Autista (Figs. 1.33 y 1.34).

Estos talleres nos permitieron recopilar un gran número de matrices latexgráficas que se trasladaron en distintas obras como Digital Archive (2019), Living Treasure (2019) y Splinters of Time (2019). Para esta última registramos la superficie de las maderas patrimoniales del edificio del MOB, todo un símbolo para el pueblo de Bydgoszcz que se forjó gracias a la industria maderera. Así como un sinfín de improntas corporales de toda la comunidad que participó, quienes gratamente donaron su huella, una vez que la imprimieron ellos mismos sobre papel. Este proyecto se realizó antes de la muestra, durante los meses de abril, para dotar de materia prima a nuestra colección y difundir en la población los conceptos más relevantes de la latexgrafia y las poéticas en torno al cuerpo, la memoria y la identidad. También se hicieron encuentros didácticos durante los primeros días de la muestra y al final de la misma. Por tanto, el acompañamiento del público es clave en nuestro proceder, ya que sin ellos no existiría la obra con la que hoy contamos y las experiencias intangibles que la respaldan. 


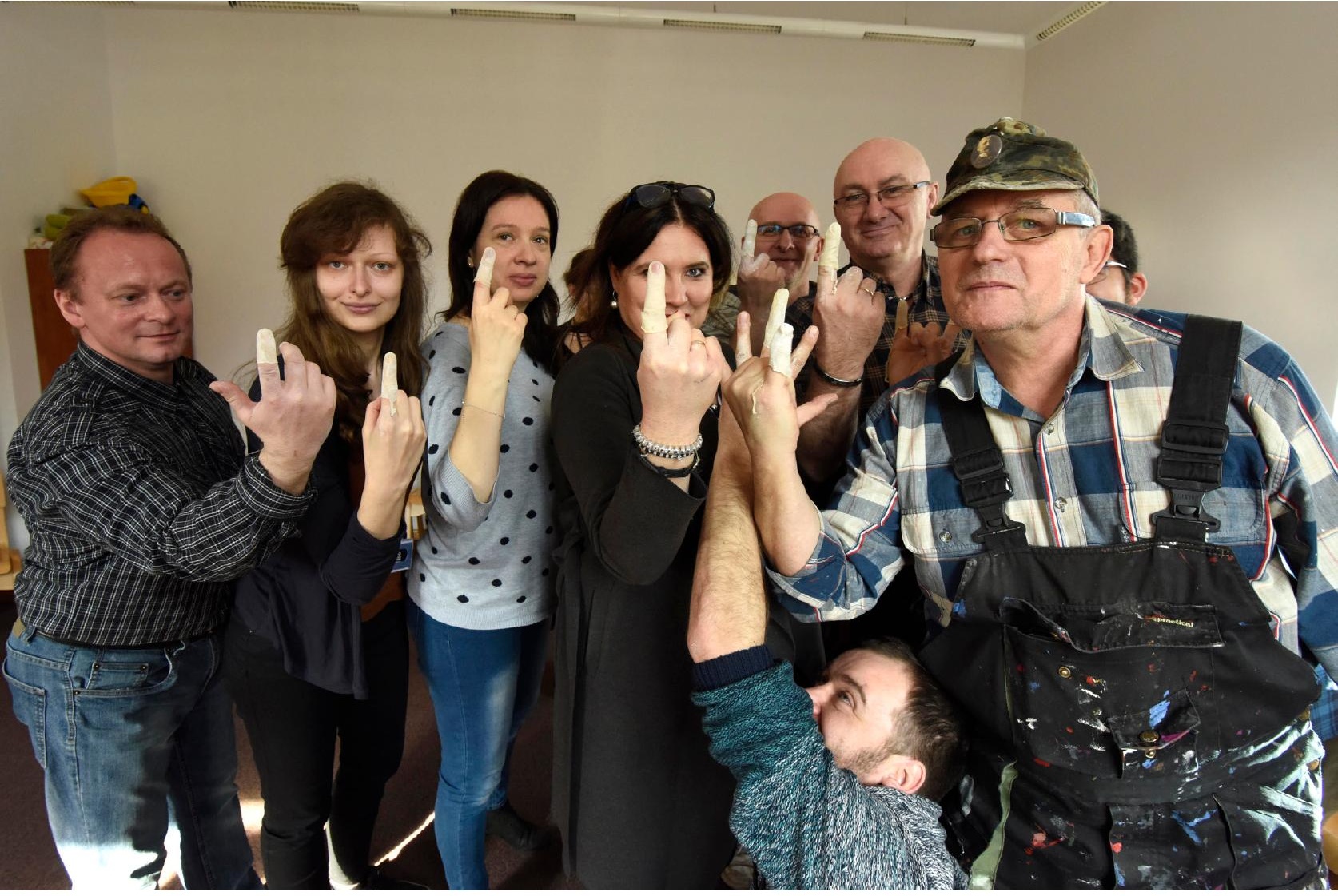

Fig. 1.33. Una imagen para nuestra historia, en ella, un pequeño grupo de los y las funcionarias del MOB, personas que desde sus ámbitos lo dieron todo para que Embodied Memory, no fuera otra exposición más, sino un documento gráfico de su memoria e identidad. 
Fig. 1.34. En este collage de imágenes se reúnen los mejores momentos compartidos antes, durante y después de la muestra Embodied Memory. En el código QR se puede visualizar un pequeño extracto de nuestras visitas guiadas. 


\subsubsection{HACIA UN GRABADO DE APROVECHAMIENTO}

La cocina de aprovechamiento es un concepto en tendencia, a pesar de que ha sido una estrategia de sobrevivencia en los hogares por cientos de generaciones. Esta idea plantea sacar el máximo partido a los alimentos respetando el valor intrínseco de las materias primas, como por ejemplo su sabor y contenido nutricional. También contempla que los procesos de elaboración y el gasto energético estén bien distribuidos, para rendir los recursos de manera austera, evitando el desperdicio y aprovechando los productos de temporada. Este es el sentido de la cultura culinaria, alrededor de la cual no solo se heredan las recetas, sino que se van incorporando en ellas nuevas formas de hacer y de pensar en torno a los alimentos, su bien social y conciencia medioambiental.

Ahora se preguntarán ¿Qué tiene que ver la cocina de aprovechamiento con el grabado latexgráfico?, Desde nuestro punto de vista, más de lo que quizás en este documento se pueda desarrollar, dado a que la pasión que nos une con el mundo de los sabores tiene un ligamen materno muy fuerte y su impacto se ve reflejado en la implementación de los valores de la cocina -antes mencionados- al mundo del arte, incluyendo el convivir y el uso directo de instrumentos cotidianos en el proceso mismo de la latexgrafía. Si bien utilizamos algunos materiales como el papel gampi y en ocasiones pan de oro en nuestras imágenes, el proceso se puede llevar a cabo, -como lo hemos hecho en nuestros talleres-, con materiales e instrumentos de bajo costo y muy fácil acceso, siendo el látex líquido natural el único que no podríamos encontrar en el bazar del barrio, pero al ser un producto de uso industrial, tampoco es inaccesible; ya que su costo es mucho menor al promedio de materiales que comúnmente forman la lista de la compra de cualquier estudiante de arte.

Sin embargo, en un futuro hemos considerado investigar en torno a la obtención directa del látex, dado a que Costa Rica (país de nuestro origen) cuenta con una diversidad desbordante donde abundan los árboles de caucho. Inclusive podríamos encontrar una fibra natural que se acerque a la del gampi y así producir nuestro propio papel. Este camino reducirá 
nuestra huella ecológica y nos llevará por parajes inciertos pero dignos de conocer. No obstante, el concepto de grabado de aprovechamiento también implica la conceptualización de las imágenes a partir de la versatilidad que nos da el medio, para sacar el máximo provecho de las matrices latexgráficas que obtenemos de nuestros encuentros con el público, utilizando los mismos moldes una y otra vez, con resultados distintos. Pero aún más importante es el hecho de que en cada taller compartimos un conocimiento básico del proceso latexgráfico en la población, despertando en ella la curiosidad por los procedimientos no convencionales del arte y la gráfica expandida. De esta manera, la brecha que por años ha existido -y que aún pervive- entre el taller del artista y la comunidad, se elimina, y ambas partes se unen en actividades lúdicas y educativas, tal y como hemos ilustrado en el apartado anterior.

En la ejecución de las obras implementamos estrategias para organizar y embalar trabajos de gran formato a través del módulo, el fragmento y los diagramas diseñados para componer, montar y desmontar la instalación en el lugar de la exhibición, tal y como ocurrió en Embodied Memory. Este proyecto ocupó apenas un volumen de cuatro cajas medianas, para una sala de más de 200 metros cuadrados, con imágenes monumentales como Digital Archive que supera los 30 metros de largo y las 3000 impresiones (Fig.1.35). Todo el trabajo previo al montaje en Polonia, se realizó en nuestro pequeño piso en Valencia, donde convertimos la mesa del comedor en un tórculo de grabado, con ayuda de un rodillo de cartón, un yoga mat y fuerza manual. Cada una de las obras fue proyectada en la galería in situ para posteriormente ejecutar gran parte de las mismas en Valencia, tomando en cuenta todos los detalles y variables de la museografía como la iluminación y mobiliario.

El montaje es un punto muy importante, ya que es parte inherente de cada obra que realizamos. En una inmensa mayoría de los casos evitamos cualquier moldura, vidrio, marco, bastidor o pedestal y nos limitamos a exponer los proyectos directamente sobre pared, suelo o cielo raso, de manera que el público pueda interactuar dinámicamente con las imágenes sin mayor interferencia, realzando las características propias que cada 
material nos suministra, por ejemplo, en el caso de la obra bidimensional impresa en papel gampi, utilizamos alfileres ultradelgados de acero inoxidable negros para sujetar cada impronta sobre una superficie adosada a la pared (Fig.1.36). De esta manera los miles de papeles se mueven con la mínima corriente de aire y tienden a crear estática con el cuerpo, hecho que agrada al público que inesperadamente observa cómo los pequeños fragmentos se erizan como si fueran los bellos de los brazos. Por tanto, la austeridad tiene que ver con una máxima del diseño que nos recuerda que muchas veces, menos es más, en otras palabras, con la economía del recurso potencializamos el discurso.

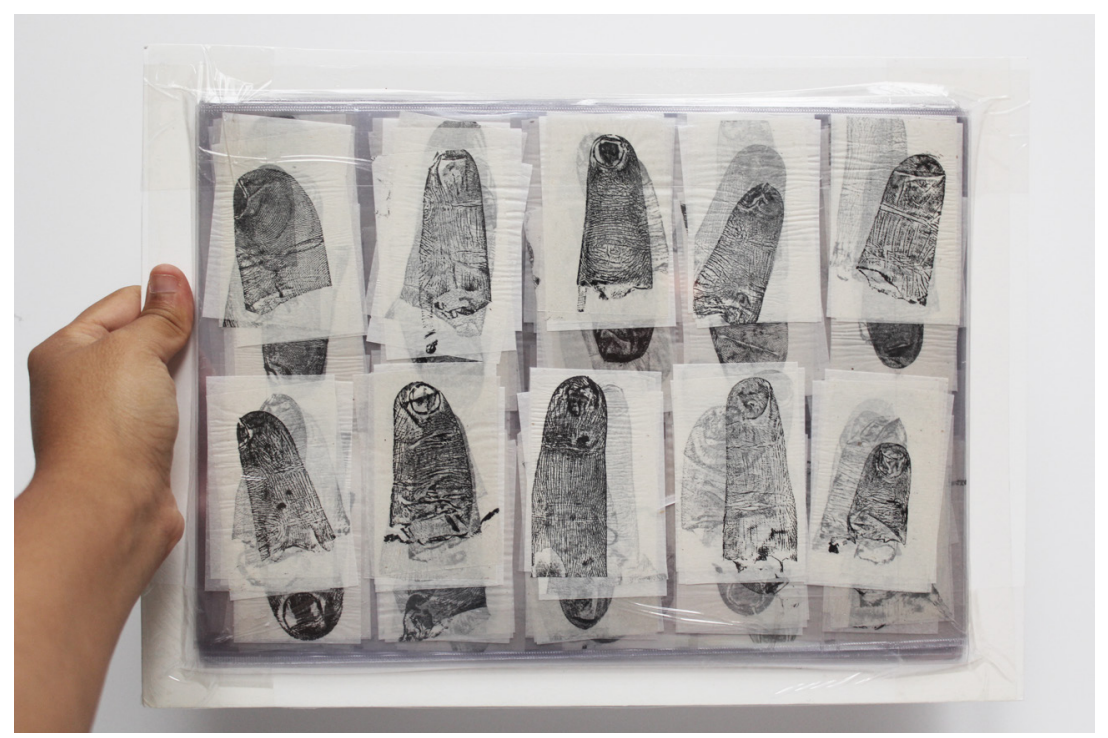

Fig. 1.35. Gracias a la estática y ligereza del papel gampi de $12 \mathrm{~g}$, sólo necesitamos 4 cartones pluma de tamaño $\mathrm{A} 4$, para agrupar 3000 impresiones, dispuestas en tacos de igual cantidad y con plástico entre cada grupo. Así se transportan y conservan las impresiones. Estas impresiones en particular, forman parte de la obra Digítal Archive, 2019. 

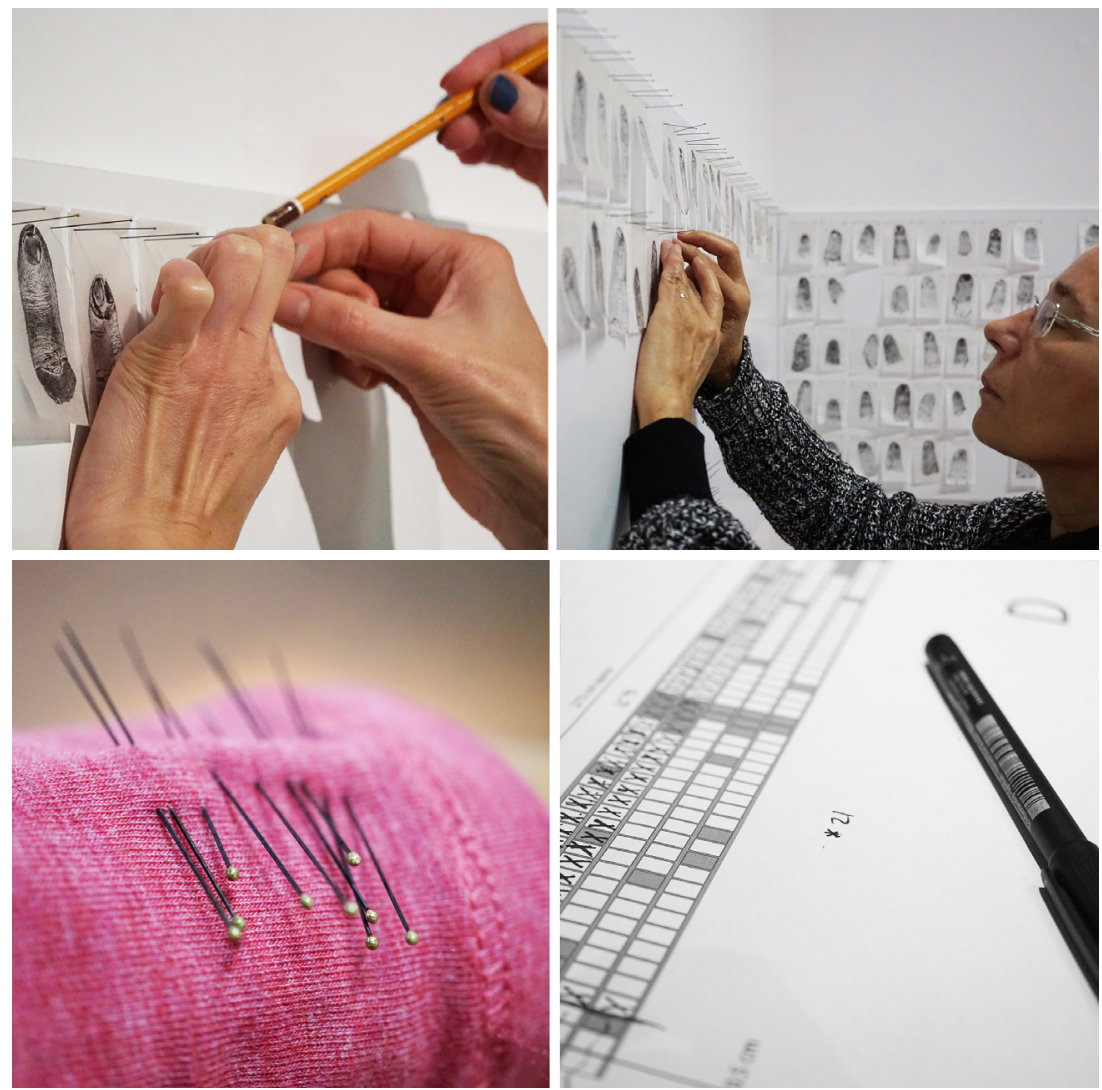

Fig. 1.36. Proceso de montaje con alfileres y siguiendo uno de los diagramas realizados para trabajos bidimensionales.

Lo importante ha sido siempre, agenciar desde lo cotidiano la forma de hacer y seguir produciendo. La necesidad es la madre de la creatividad, sólo en estos contextos uno busca alternativas para solucionar problemas plásticos, que de haber tenido a mano lo "convencional" tal vez no hubiesen surgido (Fig.1.37). En resumen, tal y como se hace en la cocina, en nuestra investigación partimos del aprovechamiento de las materias primas, potencializando el valor formal y el contenido discursivo que en ellas se encuentra. Nosotros consideramos que el tiempo es el mordiente 


$$
T
$$


que graba la memoria gráfica sobre la piel, un testimonio visual y táctil que transferimos en las matrices latexgráficas y transmutamos en una variedad de huellas.

Este acervo de texturas cutáneas es nuestro bien más preciado, por ello, en el proceso latexgráfico conservamos su estado original y dejamos intacto este tejido, resguardando, ante todo, la integridad física de la persona, porque el cuerpo propio es nuestra matriz primigenia. Esto lo hemos conseguido mediante la implementación de un proceso no tóxico, amigable con el cuerpo y compatible con el ambiente, en aras de buscar un balance entre el arte y el entorno.

Fig.1.37. Esta herramienta es un símbolo para nuestra investigación, representa cómo la austeridad de un martillo de madera para carne y un par de espumas de maquillaje pueden dar tanto juego en el proceso creativo. La ideamos para el taller con los niños de la Falla de Visitación y nos resultó tan práctico, que, lo utilizamos a lo largo de todo el proceso de Embodied Memory. 


\section{SEGUNDA PARTE}

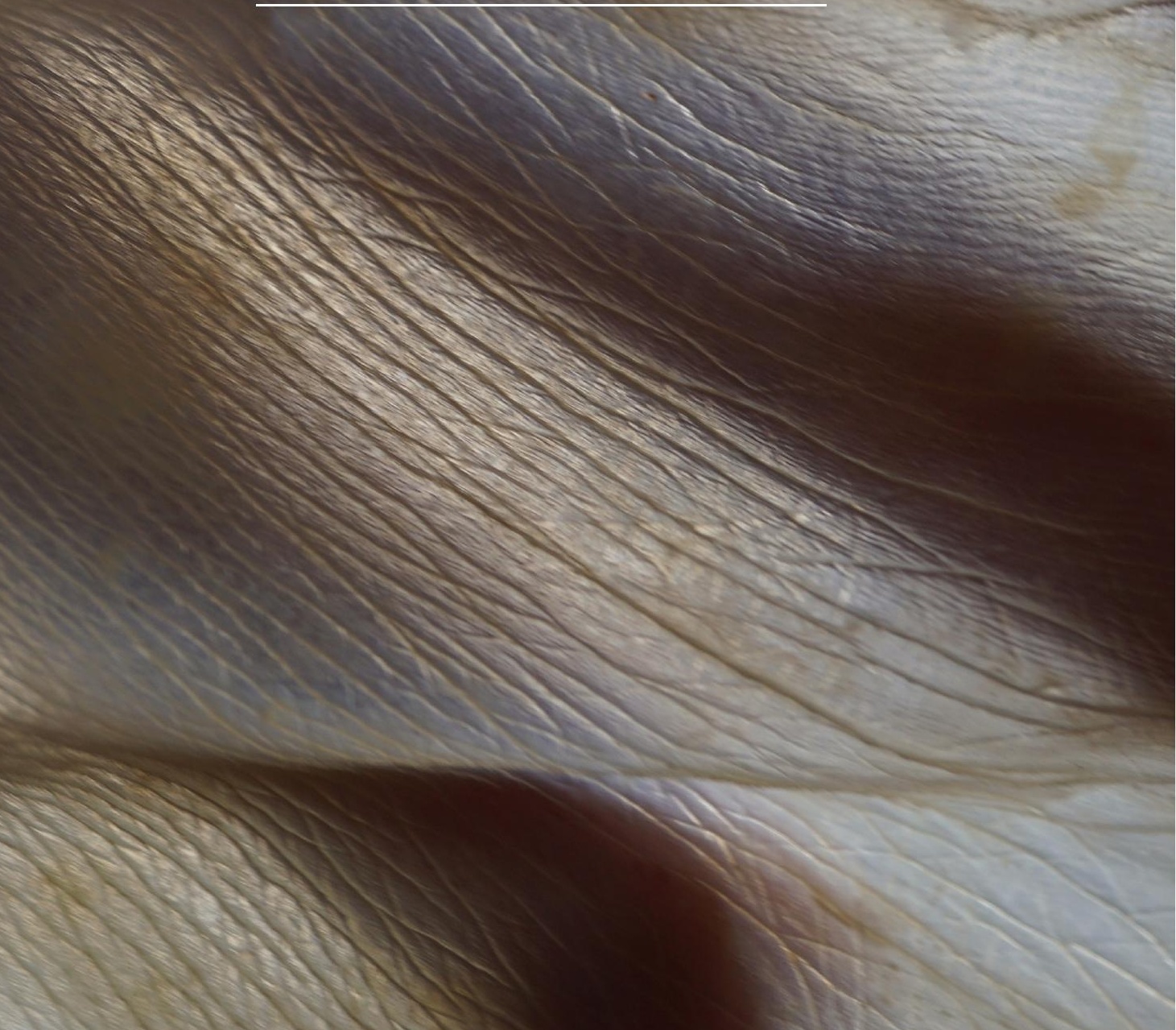




\section{POÉTICAS DEL CUERPO DESDE LA PRÁCTICA LATEXGRÁFICA}

La cuestión de la corporalidad en el pensamiento artístico contemporáneo es un camino compartido por múltiples disciplinas del conocimiento, por tanto, proponemos, en esta segunda parte, construir una lectura común que nos sirva de hilo conductor a lo largo de nuestra investigación, que nos permite reflexionar en torno a las poéticas del cuerpo desde la implementación de la latexgrafía como medio expresivo.

En la práctica artística objeto de nuestra investigación, la noción de cuerpo se imbrica con la piel, concebida como la superficie simbólica sobre la cual el tiempo graba la memoria gráfica de nuestra existencia. Al desdoblar la imagen corpórea y transferir su huella epidérmica, se expanden consigo las lecturas asociadas a determinados cánones que rigen la percepción y representación imaginaria del cuerpo en nuestra sociedad. En virtud de esta experiencia técnica, podemos aproximarnos a los fragmentos corporales dislocados de su unidad jerárquica y forma convencional, para transitar entre los múltiples pliegues de sus significados. En tanto, desde nuestro enfoque la huella de la piel encarna la imagen corpórea. Una piel que hace de frontera biológica y sociocultural con el mundo, en cuya impronta se encriptan las marcas que definen la heterogénea condición humana. A continuación, abordaremos tres ejes discursivos en torno a los cuales articulamos los referentes teóricos y conceptuales de nuestra tesis: el sentido de los cuerpos, las imágenes y las pieles.

\subsection{EL SENTIDO DE LOS CUERPOS}

¿Qué sentido le otorgamos al cuerpo en la presente tesis? Pensar el cuerpo es en gran medida hacerse cómplice suyo, operar en el ámbito del pensamiento la transgresión que el cuerpo opera realmente en el orden social y simbólico (Ginés Navarro, 2002, p. 201). El concepto de cuerpo que prevalece en nuestras sociedades occidentales es una herencia de la modernidad; en esta coyuntura positivista se dio la división entre cuerpo 
y persona, dando origen al concepto de individuo; una visión dualista que junto con el imaginario cristiano aún sigue vigentes en nuestros días. La realidad objetiva del cuerpo y sus múltiples significados son un constructo teórico, en tanto, el significante cuerpo es una ficción que opera culturalmente y responde al imaginario simbólico de cada colectivo social, dando sentido de pertenencia a los individuos que lo conforman en un determinado espacio temporal, según apunta Le Breton (2018).

Dicho esto ¿cuáles han sido nuestros pilares teóricos en la construcción conceptual del cuerpo? En primer lugar hemos de demarcar que nos identificamos tanto con los aportes del giro corporal fenomenológico así como con los puntos de inflexión filosóficos a razón del cambio de paradigma de la modernidad, en la lógica del discurso postauschwitziano, que generó una crisis en los modelos de representación que tomarían fuerza a partir de los años 70 hasta nuestros días, gracias a los diálogos interdisciplinarios que se conjugan en el arte contemporáneo, cuya heterogénea plataforma sirve para proyectar manifestaciones que apelan a la emancipación del cuerpo propio de las estructuras normativas del sistema, como lo son: los movimientos feministas, poscoloniales y LGTBIQ, entre otros. En esta coyuntura sociocultural surgieron a mediados del siglo XX manifestaciones artísticas precursoras como el happening, el accionismo vienés y el body art , que hicieron del cuerpo su medio, soporte y mensaje para experimentar el mundo, convirtiéndolo en el espacio de subversión política por excelencia y sentando un precedente para que propuestas como la nuestra -y tantas otras- hoy se reescriban en relación con el momento histórico en el que se inscriben.

En el imaginario corporal del siglo XXI coexisten los sesgos ideológicos heredados de épocas pasadas, con los rasgos actuales, a manera de capas de un palimpsesto. En consecuencia, el cuerpo tiene para nosotros una dimensión polisémica como superficie de inscripción, visualización y representación de las diversas experiencias vivenciales. Hoy día, la percepción del cuerpo se expande en el espectro de lo virtual y penetra la realidad apercibida por el sistema visual, para mostrarnos como nunca antes las distintas dimensiones de lo que siempre hemos sido. Una 
paradoja contemporánea, puesto que ese cuerpo que somos nunca ha estado tan registrado y reproducido en imágenes, nunca se ha fragmentado en partes tan pequeñas para conocer sus códigos genéticos y descifrar los enigmas médicos, pero también nunca se nos ha manifestado tan lejano e inaprehensible en nuestra imaginación como ahora. Por ello es preciso indagar en el sentido que aún pueda permanecer irreductible y para ello se deben ir despellejando sus capas, tal y como lo expone David Pérez (2004):

De ahí que cualquier discurso dirigido a analizar este proceso de desnudamiento se transforme en una reflexión que busca descubrir más que el cuerpo de una verdad, la verdad de un cuerpo, o mejor aún, de unos cuerpos que, reducidos a simbolizaciones de toda índole -las concebidas de genero, raza, clase...- intentan, pese a la fragilidad de sus propias incertidumbres, leer el sentido de ese oculto sin sentido con el que inadvertidamente han sido escritos. (p. 12)

Un sentido que en el marco de nuestro trabajo se encuentra grabado en la piel, en tanto que superficie corporal mediante la cual entramos en contacto con el mundo, situando al cuerpo como punto de encuentro fenomenológico. El cuerpo deviene en piel en el presente estudio, ella es la superficie que lo envuelve y el soporte simbólico y político donde se imprimen los avatares de la vida, mediante los cuales somos percibidos, tanto por los demás como por nosotros mismos. Dicho esto, creemos preciso subrayar que la dimensión del arte corporal con la que nos identificamos se aleja de aquellas manifestaciones que atentan o alteran la integridad física de las personas participantes, dado que en la latexgrafía utilizamos medios poco invasivos y no tóxicos para simular el desollamiento y muda de la piel, de modo que la persona no sufre ni un rasguño durante el proceso creativo. Finalmente podemos trasmutar la huella intacta de la piel en una superficie expresiva, para estudiar a fondo esos textos inadvertidamente escritos y no alterar su verdad. En suma, no vemos la necesidad de infringir dolor o violencia para despertar la empatía e imaginación del público y los colaboradores, muy al contrario, planteamos la ficción lúdica como estrategia visual para consumar nuestro rito artístico. 
Dentro del amplísimo territorio de las prácticas artísticas contemporáneas Hernández-Navarro y Cruz (2017) nos proponen la construcción de una cartografía para ordenar y relacionar dialécticamente las dimensiones del cuerpo que prevalecen en el arte hoy. Dentro de este estudio se distinguen dos grandes focos de agrupación: el primero corresponde a la Visualización del cuerpo como soporte, entendido como un conjunto de estrategias performativas (cuerpos dolientes, fluyentes, activistas y ausentes) y el segundo a la Representación del cuerpo-soporte, en tanto que estrategias que articulan la referencialidad del cuerpo (cuerpos narrativos, fragmentados y transformados).

Por consiguiente, la presente sistematización nos permite situarnos -aunque de forma fluctuante-en la intersección que vincula la visualización del cuerpo ausente con la representación del cuerpo fragmentado. Este es el lugar en el que nuestra propuesta se desarrolla; ya que desde la fragmentación se suprime toda relación unitaria y jerárquica del cuerpo, para que sean sus huellas, rastros y residuos los que re-presenten metonímicamente a esa referencia corporal ausente y rindan testimonio a su memoria encarnada en la piel.

Es decir, en esencia: una nueva vanitas que se articula en torno al tiempo y la fugacidad de la vida, aglutinados ambos en el papel de la memoria y el recurso de la huella, la traza, el resto o el fragmento. (Ibidem, 2017, p. 27)

En consonancia con la anterior cita, podemos remarcar que la noción residual, fragmentada y ausente del cuerpo, sumada al giro de la memoria, son parte de las secuelas del impacto ideológico que el Holocausto causaría en los paradigmas del arte y la cultura. Un punto de inflexión con el que nos sentimos tremendamente identificados, motivo por el cual es evidente su influencia en la construcción del imaginario del cuerpo de la presente tesis. Las razones de este nexo giran alrededor de nuestro interés por la memoria visual del Holocausto y nuestros vínculos profesionales con Polonia, así como la innegable repercusión en la historia de este catastrófico evento, puesto que visto desde un espectro más amplio que el problema entre los judíos y los nazis, el Holocausto representa el desgarro 
de la moral y el espíritu del proyecto civilizatorio de la modernidad. Con esta ruptura los preceptos que sostenían la unidad de sentido del cuerpo quedaron reducidos a escombros de lo que algún día se imaginó. Este carácter testimonial incide directamente en nuestra labor, dado que cada huella latexgráfica es el vestigio material de encuentros efímeros que se fraguan en una matriz, superficie que registra el aquí y el ahora, un estado determinado de una persona u objeto, un presente que deviene ausente en el momento justo en que el molde se desprende del cuerpo para pasar a formar parte de un acervo colectivo de fragmentos anónimos.

Como nos recuerda Adorno (1962) después de Auschwitz escribir poesía es un acto de barbarie. Una frase para la historia, con detractores y seguidores, pero ciertamente rotunda. Ello implica que el concepto de mundo entró en una crisis existencial, por ende, las formas de hacer y pensar el arte también lo hicieron. Desde entonces, en el arte contemporáneo ha habido una creciente tendencia a transgredir la autonomía moderna y la hegemonía de los discursos ideológicos que la fundamentaban. Según se fueron desmaterializando las categorías estéticas de las vanguardias, el arte corporal se ha venido construyendo a través del concepto, el proceso y la experiencia. Por ende, el cuerpo pasaría de ser un sustantivo, a devenir en verbo y acción subversiva. Afín a esta línea de pensamiento, nos acercamos al cuerpo como quien abre una fosa común y se encuentra con vestigios arqueológicos, en la que cada parte tiene grabada una historia gráfica de supervivencia, resistencia y sublevación.

Planteamos que desde la deconstrucción de la forma convencional del cuerpo se abra el contenido que esta encierra y así poder vaciar los atributos preconcebidos y simbolizaciones de toda índole encarnados en nuestra imagen corporal. Es decir, arrancar de raíz esos arquetipos que proyectamos, que nos supeditan a determinadas maneras de ver y ser vistos según sea nuestra etnia, género, sexo, color de piel, ideología política o religión. Vinculando todo ello a la práctica latexgráfica, este planteamiento se expresa al extraer los moldes de la piel, acto en el se desgarra y rompe la referencia jerárquica y unitaria del cuerpo; 
su apariencia convencional y reconocible desaparece para dar paso al fragmento y sus múltiples posibilidades de expansión en el espacio.

En nuestra investigación nos inclinamos por ahondar en la experiencia del cuerpo como medio de interacción con el mundo, por ello situamos a la persona como artífice de sí misma, en su capacidad de redescubrirse infinitamente en sus pliegues e identificarse en la huella del otro. Parafraseando a Deleuze (1989) el pliegue es la matriz de representación que se extiende al infinito. El concepto del pliegue nos ayuda a comprender la complejidad de lo simple, de esas muecas y gestos que nos permiten ser quienes somos y descubrir lo extraordinario de lo ordinario; en otras palabras, percibirnos con otra mirada, tenemos esa capacidad de desdoblarnos. De igual manera, la plasticidad de la materia se relaciona con nuestro trabajo técnico y su dimensión poética, dado que en el cuerpo no existen oposiciones dualistas sino conexiones elásticas; por ejemplo la relación entre los conceptos de la matriz primigenia, la matriz latexgráfica y la huella latexgráfica, donde la primera engendra a la segunda y esta última engendra a su vez a las subsiguientes, las cuales pueden ser tanto huellas como matrices, dependiendo de la materia que reciba la impronta. Así el continuo pliegue se expresa desde la práctica misma de la latexgrafía, mediante el encadenamiento constante de las variables del proceso.

A razón de las ideas planteadas por Deleuze, desde nuestro enfoque la fragmentación no se comprende como una división, sino como una expansión de la forma en la que sus límites convencionales se pliegan y repliegan. Cada pliegue es una repetición de un movimiento, es decir, del acto mismo de dejar huella y el contacto entre superficies y materiales, pero cada modulación de este movimiento crea por sí mismo una diferencia, dado que no hay dos improntas iguales, aunque provengan de la misma matriz latexgráfica; ya que en el caso del cuerpo, en tanto que matriz primigenia, está en cambio constate. Por su parte la matriz de látex nos permite jugar con sus infinitas variables de impresión gracias a su materialidad elástica y flexible. La unidad simbólica del cuerpo se abre y extiende como un gran mapa orgánico compuesto de pequeños 
fragmentos modulares, de patrones dactilares y texturas cutáneas que pueden ser tanto nuestras como suyas.

Por ende, nos identificamos con una visión rizomática que pone en cuestión la representación de la realidad objetiva y los valores asociados al cuerpo como unidad de sentido. En consecuencia, en nuestras composiciones es posible que la huella del ombligo se yuxtaponga a la oreja, el codo a la uña del pie o una rodilla con los párpados. Cada una de estas partes tienen un potencial para generar otros cuerpos posibles que se reproducen sin cesar. Por ello transgredimos intencionadamente la proporción y la forma que designa la apariencia del cuerpo. Nos acogemos a lo que desde el pensamiento de Bataille (1985) se conoce como lo informe, es decir, la disolución y desclasificación del estatuto formal de las cosas; para expandir las estructuras rígidas y cerradas que limitan al mundo a tener una forma determinada. En afinidad con el enfoque de Bataille, creemos que la experiencia corporal más profunda se alcanza cuando nos despojamos de los personajes, disfraces, vestiduras y prejuicios que se encarnan en la piel. Esto implica desacralizar y desgarrar el cuerpo de las ataduras del dogma, de los arquetipos de belleza o los roles de género, llevarlo al borde liminal, al límite mismo entre lo humano y lo animal. La idea es podernos re(conocer) en un pellejo de látex, aceptar nuestra condición carnal, mutable y finita, porque como bien nos recuerda Kristeva (2006): "Fuera de lo sagrado, lo abyecto se escribe" (p. 27).

La ambigüedad del cuerpo abyecto e informe se encuentra como posibilidad en la técnica latexgráfica al simular el acto del autodespellejamiento e imprimir su huella desagarrada, porque en esta simple acción nos estamos abyectando a nosotros mismos y construyendo la forma informe del otro. Por tanto: "Estaríamos ante una nueva especie de realismo que no consistiría en representaciones de lo más realistas posibles, sino más bien en (re)presentaciones de lo insoportable" (Cunillera, 2007, p. 127). Pero quizá, lo verdaderamente insoportable no sea la dimensión biológica del cuerpo y su proceso natural de envejecimiento, esos kilos de más o los pellejos corrugados por el tiempo, sino, la violencia sistémica con la que socialmente normalizamos que el cuerpo propio se haya convertido en 
un valor de cambio y ser nosotros mismos los fieles verdugos de nuestra autoexplotación, situación que no hace más que agrandar la brecha que divide nuestro ser corporal y el mundo.

Por su parte la otra perspectiva filosófica en la que nos apoyamos corresponde a la fenomenología, la cual nos brinda una visión conciliadora entre el ser y el mundo, que recae sobre los aportes precursores de Husserl, Merleau-Ponty y más contemporáneamente Marc Richir y Pallasmaa, entre otros. Al respecto, Merleau-Ponty (2010) nos recuerda que el cuerpo y el mundo están hechos de la misma carne, nos hacemos mundo al mismo tiempo que este se hace cuerpo. Lo que concebimos como realidad es lo que experimentamos corporalmente y la piel es esa membrana que entrelaza el contacto de ambos fenómenos. Tal como si fuera una banda de Moebius que se mueve en el espacio, cuando dejamos una huella en el mundo este imprime la suya sobre nuestra piel. Esta encarnación reversible es imprescindible en nuestro trabajo y es lo que desde el pensamiento merleau-pontiano se entiende como el quiasmo, es decir, la disolución de todo razonamiento dualista. Desde nuestra práctica, imbricamos la reflexión fenomenológica al trasmutar la piel en una matriz de látex sobre la cual se trasfiere el rastro tangible y la memoria gráfica de nuestro ser-en-el-mundo.

No obstante, la relación quiasmática no sólo comprende las experiencias con el entorno y cómo nos autopercibimos, sino que incluye el vínculo con las demás personas y la disyuntiva histórica entre el ser o tener cuerpo. Al respecto, Marc Richir (2016) nos plantea la siguiente reflexión: "Esta división de la cuestión entre el tener y el ser dejaría escapar lo esencial: la experiencia del cuerpo moviéndose entre estos dos polos" (p.11). La pregunta sería entonces ¿Quién tiene o posee ese cuerpo sino es uno mismo? La construcción de nuestra identidad es fruto de las huellas que han ido dejando las personas y las experiencias compartidas en el devenir de la vida. Por ende, pensamos el cuerpo en relación al otro. Un otro -que comenzando por nosotros mismos- casi siempre nos parece extraño y se nos manifiesta enigmático. Cada poro de nuestra piel es un territorio por descubrir, cuya bella extrañez atenta contra los parámetros estéticos. 
Nuestra imagen corporal se encarna en la memoria de la piel cual si fuera un texto escrito en braille que se descifra al tacto.

En resumen, el cuerpo-piel es para nosotros el símbolo de la condición humana y sus inherentes contradicciones, la matriz primigenia sobre la cual el tiempo graba las experiencias vivenciales. Cuando la superficie de la piel se desdobla, se expande también la memoria gráfica que en ella se archiva. Bajo esta concepción, la técnica de la latexgrafía no sólo es el medio, sino el puente conceptual para imbricar las contingencias del pensamiento contemporáneo en torno a la noción de cuerpo; aquellas que hemos expuesto brevemente en este apartado y que nos han servido de aliciente fundamental para romper los moldes preconcebidos y expandir nuestra creatividad en terrenos experimentales y fértiles. Creemos que reflexionar en torno al cuerpo desde la práctica artística más que un acto racional implica una experiencia multisensorial, en la que a través de la expresión artística transcribimos en formas, texturas y signos, lo que sentimos a flor de piel.

El cuerpo, piel: todo lo demás es literatura anatómica, fisiológica y médica. Músculos, tendones, nervios y huesos, humores, glándulas y órganos son ficciones cognitivas. Son formalismos funcionalistas. Pero la verdad es la piel. Está en la piel, hace piel: auténtica extensión expuesta, completamente orientada hacia el afuera al mismo tiempo que envoltorio del adentro, del saco lleno de borborigmos y de olor a humedad. La piel toca y se hace tocar. La piel acaricia y halaga, se lastima, se despelleja, se rasca. Es irritable y excitable. Toma el sol, el frío y el calor, el viento, la lluvia, inscribe marcas del adentro -arrugas, granos, verrugas, excoriaciones- y marcas del afuera, a veces las mismas o incluso grietas, cicatrices, quemaduras, cortes. (Jean-Luc Nancy, 2016, p. 116) 
Históricamente en occidente las imágenes y el cuerpo han sido dos piedras angulares a partir de las cuales se concibe simbólicamente la condición humana. Como veremos en este apartado, en el marco de nuestro estudio, se hace referencia a distintas concepciones de la imagen, que se entrelazan al hilo de nuestro enfoque. A continuación, una breve revisión de estas perspectivas, y cómo se filtran a través de la práctica y conceptualización de la latexgrafía.

\subsubsection{IMÁGENES ANTROPOLÓGICAS}

A continuación, iniciaremos este recorrido desde la visión antropológica planteada por Belting (2007) quien sostiene el nexo indisoluble del trinomio medio-imagen-cuerpo, con el cual comulgamos y que el autor define de la siguiente manera:

Desde la perspectiva antropológica, el ser humano no aparece como amo de sus imágenes, sino -algo completamente distinto- como "lugar de las imágenes" que toman posesión de su cuerpo: está a merced de las imágenes autoengendradas, aunque siempre intente dominarlas. (pp. 1415).

Este aspecto es fundamental para comprender que, desde esta perspectiva, las imágenes son todas aquellas representaciones que mediante el cuerpo se piensan, crean, recuerdan y reconocen. Las imágenes pueden ser materiales, fílmicas, virtuales o mentales, en forma de palabra, sonido, figura literaria, recuerdo, gesto o sueño. En resumen, todas las acciones corporales y sus respectivos registros culturales, en las que las imágenes artísticas y sus múltiples expresiones, son tan sólo una de sus posibles manifestaciones. Por ende, alineados con el pensamiento de Belting, consideramos que el cuerpo propio es el emplazamiento donde las imágenes cobran sentido, de ahí que le otorgamos el papel de la matriz primigenia y el medio vivo desde el cual transmutamos la huella de la piel en huella latexgráfica. En el marco de nuestra experiencia, las imágenes 
representan la evidencia material del contacto entre dos realidades que se imbrican fenomenológicamente, como el entrelazo del cuerpo y su huella, la matriz y su impronta, la sociedad y la artista.

\subsubsection{IMÁGENES MATRIZ E IMÁGENES MATERIA}

Por una parte la imagen matriz, planteada por Didi-Huberman (2015), y por otra la imagen-materia, o imagen encarnada, propuesta por José Luis Brea (2016). La imagen matriz se concibe como el remanente físico de las acciones corporales catalizadas en el contacto físico, en el que se transfiere una impronta de un soporte a otro mediante la impresión; en nuestro caso, el contacto entre el látex líquido natural y el cuerpo, o este último, con alguno de los materiales que utilizamos para fraguar su huella. Por tanto, la impronta, simbólicamente, funciona para registrar momentos efímeros y superficies en continuo cambio, como la piel, susceptibles al tiempo y la muerte. Así, los moldes han registrado y retratado, desde la antigua Roma, un estado determinado de la persona que se transmuta en una evidencia fáctica de un aquí y un ahora. Para Didi-Huberman (2015) la imagen-matriz se caracteriza por su modelo técnico ritual, tal y como el mismo lo expone a continuación:

El modelo técnico de la impresión revela aquí toda su eficacia simbólica: por un lado, el molde realizado directamente sobre el rostro garantiza metonímicamente la presencia única e inamovible del referente de la representación; por el otro lado, la tirada positiva garantiza la posibilidad de una multiplicación indefinida que responde a todas las combinaciones posibles (...) Tal es, sin duda, su más fundamental eficacia jurídica: instituir la semejanza como ritual de duplicación táctil -y no como retórica de representación óptica-del origen. (pp. 126-127)

En otras palabras, la acción de la impresión remite a una extracción de un fragmento corporal de una persona y busca la semejanza máxima de su registro. El cuerpo presente ratifica la verdad de la impronta, la cual no se puede realizar de otra manera, solamente es posible cuando se materializa el contacto fugaz entre el cuerpo y el material. Por ende, este proceso de registro de huellas tiene una dimensión ritual en nuestro 
trabajo, ya que estamos inmortalizando ese instante. En tanto, la imagenmatriz se produce por la adherencia y requiere del contacto directo. La imagen se engendra en dicho acto.

Nuestras imágenes remiten a su naturaleza mnemónica para evocar la conexión entre la ausencia y la presencia, el pasado y el presente, la realidad y la ficción, el cuerpo y el mundo. En su condición objetual, son el resultado tangible de la experiencia técnica de la latexgrafía, no obstante, en su dimensión simbólica carecen de materia física porque están hechas de emociones y sensaciones, de recuerdos y relatos anónimos que se entretejen en la experiencia háptica, en la memoria encarnada en la piel. Sin embargo, esta dialéctica, no sería posible si la imagen no se engendra desde la materia, o mejor dicho, si la materia no encarnara ese proceso en el que creamos una imagen (imagen encarnada), así también lo sostiene Brea (2016) cuando reflexiona sobre el nexo del tiempo de la materia, la imagen y la memoria:

El tiempo de la imagen, en efecto, es un tiempo estático, único. Pero claro, es: bajo este específico modo o régimen técnico -que es propio de la imagen-materia-. Uno que se aplica a producirlas moldeándolas en ella, en materia, produciéndolas con ella, de ella, fabricándolas como unidas indisolublemente a su soporte. De esta unión indisoluble y de la consiguiente unidad estática de su tiempo de narración, interno, se sigue toda su potencia de promesa, la peculiar forma en que estas imágenes son -y han sido- siempre para nosotros, sobre todo, memoria, escritura de retención contra el pasaje del tiempo. (p.12)

A propósito de esto, podríamos considerar que nuestras imágenes son la materialización de la memoria escrita por el tiempo sobre el cuerpo, en su piel, como superficie simbólica de percepción del yo y del otro. Una imagen matriz que encarna un acontecimiento simple, el contacto, el aquí y el ahora. La impronta desdoblada del cuerpo que se transmuta en un material cargado de sentido poético, que nos viene hablar en nombre de los ausentes, y sobre todo, a perpetuar su memoria, cuando ya no están. Más que materializar un pasado, lo que hacemos es darle forma a un presente fugaz, para retener la huella de lo inaprensible. 


\subsubsection{IMÁGENES POÉTICAS}

Consideramos que nuestras imágenes son la huella de la experiencia participativa, una forma creativa de registrar el arte de vivir y la vivencia del arte como proceso de aprendizaje. Lejos de ser un resultado acabado, consideramos que nuestras imágenes son indicios que apelan a la capacidad imaginativa y crítica del artista y del espectador como co-autor, para confrontar lo que cada quien asume como su realidad y la imagen que le representa. Pero, ante todo, buscamos ponernos en la piel del otro y construir una imagen poética que encarne esta experiencia vivencial.

Partimos de la construcción conceptual de la imagen poética que articula Pallasmaa (2014) en su libro La Imaǵen corpórea, ensayo donde plantea múltiples enfoques de la imagen alrededor de la perspectiva fenomenológica, en la que conjuga la experiencia de la imagen desde la vivencia del cuerpo y su indisoluble conexión con el entorno. Así, el arte se concibe como una representación metafórica del encuentro entre el artista y el mundo; acto en el que este da forma simbólica a sus avatares, sueños, frustraciones e ideas, de una manera multisensesorial, involucrando tanto la dimensión material de la imagen como su carácter imaginario desde lo íntimo hasta lo colectivo. Esta tensión constitutiva, es lo que él categoriza como La existencia dual de la imaǵen poética, concepto con el cual nos identificamos y nos vemos retratados, cuando el fenomenólogo describe esta dimensión de la siguiente manera:

La imagen mental o vivida constituye un concepto central en todas las artes, aunque pocas veces los artistas o los teóricos se refieren a ella; cuando se menciona, suele utilizarse la palabra "imagen" para referirse a fenómenos puramente perceptivos y visuales. Sin embargo, la imagen es la entidad de la experiencia, la singularidad perceptiva, cognitiva y emocional sintética la obra de artística que se percibe, corporiza y recuerda. Constituye, a la vez, la identidad de la obra, el núcleo mismo de su impacto y de su significado emocional y vivencial. La imagen poética es una entidad vivencial imaginaria específica que tiene una identidad, una anatomía y una esencia cohesivas. La imagen poética redirige y enfoca la atención del espectador/oyente/lector/ocupante y da lugar a un estado 
de alteración de la conciencia que evoca una dimensión imaginaria, un mundo de la imaginación. (pp.117-118)

En otras palabras, cuando el artista está profundamente conectado con la poética de su imagen, pero que, al mismo tiempo, tiene el potencial para desdoblarse y verse desde afuera al incorporar al público dentro de su universo ficcional; un mundo imaginario creado en y desde la imagen. Es precisamente, esa estrategia para integrar al otro en los procesos creativos, lo que abordaremos en el siguiente apartado.

\subsubsection{IMAGINACIÓN Y FICCIÓN ARTÍSTICA}

Una vez hemos esbozado las concepciones de imagen que nos han servido de anclaje en la conceptualización de la práctica de la latexgrafía, es preciso acotar brevemente el significado de imaginación y el papel preponderante de la ficción como estrategia de comunicación plástica en nuestra investigación. Empezaremos por preguntarnos ¿A qué llamamos imaginación en la presente tesis? Comúnmente, cuando hablamos de la imaginación pensamos en el proceso creativo mediante el cual generamos representaciones mentales y manifestaciones sensoriales que sólo existen en nuestro interior. Muchas veces frivolizamos este acto como carente de sustento real y fantasioso, sin embargo, la imaginación es más importante de lo que muchos creen, puesto que mediante el imaginario simbólico dotamos de significado al mundo que nos rodea. En el campo artístico hacemos uso del poder comunicador de la imagen, pero poco nos detenemos en pensar la estrategia que utilizamos para estimular a las personas a ingresar en nuestro universo ficcional, para provocar intencionalmente una reacción determinada con y desde nuestros proyectos. Este proceso es lo que desde la lectura estética de Schaeffer (2012) se conoce como la modelación analógica, concepto al que nos acogemos y que él define con estas palabras:

La modelación analógica. Si la ficción implica una simulación (lúdica), una producción de señuelos y un proceso de inmersión mimética, el objetivo del proceso ficcional no radica, sin embargo, en la simulación en cuanto tal, en la imitación-semejanza, sino en aquello a lo que nos da acceso, esto es, el universo ficcional. (p.96). 
Así pues, desde nuestro campo de trabajo, estos señuelos son los moldes corporales que denominamos matrices latexgráficas, y la inmersión mimética, el proceso técnico mediante el cual las obtenemos: la latexgrafía. A través de esta técnica creamos un espacio ficcional donde cada persona se desdobla en su propia piel, autodespellejándose en un rito técnico que transforma lo que podría ser un acto siniestro, como el desollamiento, en una actividad lúdica donde simulamos la muda. Metafóricamente, es un renacer en una segunda piel, que lejos de remarcar los modelos canónicos nos ofrece una imagen informe, en la que la hiperrealidad de la huella deviene en abstracción. Cada quien y a su manera, establece un diálogo con lo que simbólicamente representa ese trozo de sí hecho materia y cómo, concuerda o no, con los arquetipos y estereotipos vigentes. "Así, un modelo ficcional es capaz de ser no sólo un modelo de la realidad sino también contra la realidad" (ibidem, p. 98).

Ahora bien, esta modelación analógica también incluye al público que no ha sido partícipe del proceso latexgráfico; dado que el montaje de las imágenes está dispuesto para interrogar su mirada e invitarle a reconstruir - a partir del fragmento, la huella y el indicio- un supuesto orden del cuerpo, tal como si fuera un puzle en el que sus piezas no corresponden a la imagen predeterminada, porque si bien son huellas del cuerpo, estas no se asemejan a las representaciones convencionales del mismo. En esta exploración detectivesca cada quién da rienda suelta a su imaginación para darle un sentido a las matrices y huellas latexgráficas que conforman nuestras imágenes. Creemos, que si podemos imaginar(nos) desde una perspectiva no canónica, e incidir en la inclusión y la multisensorialidad como el medio para percibir una experiencia vivencial más completa, entonces nuestras imágenes tendrán el potencial para generar cambio, para romper con los moldes previos y servir de resistencia ante la homogeneización que promueve el sistema. Si cada quien puede desprenderse de sí y ponerse en la piel del otro -comenzando por sí mismo-, entonces nuestra labor artística cobra sentido, porque, aunque sea por un instante efímero, hemos creado una ilusión para volver a experimentar lo ordinario del cuerpo de una manera extraordinaria. 
En una sociedad cada vez más digitalizada los seres humanos hemos experimentado cómo diariamente se reducen los espacios de interacción corporal. A las puertas de la cuarta revolución industrial e inmersos en una pandemia global, los procesos de virtualización y modalidad remota se aceleraron vertiginosamente, impregnando todos los ámbitos de nuestra vida cotidiana. Ante la notoria ausencia de la presencialidad y la debilitación del estatuto de verdad que han sufrido las imágenes, a razón de su reproducción masiva y manipulación exponencial, nos preguntamos: ¿es el cuerpo el lugar primigenio de la percepción? ¿podremos revalorizar el contacto directo con el mundo al término de esta crisis?

Preguntas que quedan abiertas y que sólo encontrán con el tiempo su respuesta. Al menos desde nuestro estudio creemos que el sentido del tacto y la acción del contacto con el mundo no desaparecerán, pero si se adaptarán intuitivamente a las nuevas superficies e interfaces, como lo han hecho con las pantallas; sin embargo, si estas últimas abarcan y sustituyen los espacios de interacción con lo real, la idea de mundo que hemos construido mediante la imaginación, la experiencia háptica, la identificación y proyección, cambiará drásticamente y con ello los procesos facultativos de cognición y percepción humana. Como bien afirma Pallasmaa (2017): "Nuestro contacto con el mundo tiene lugar en la línea limítrofe del yo a través de partes especializadas de nuestra membrana envolvente" (p.13). Es decir, de nuestra piel en todas sus dimensiones, las mismas que desarrollaremos a continuación y que se comprenden en: Dimensiones epidérmicas y Entre la muda y el desollado.

\subsubsection{DIMENSIONES EPIDÉRMICAS}

Como veremos en este apartado, en la vida cotidiana empleamos tantas metáforas de la piel como poros hay en su superficie. Cuando coloquialmente decimos "a flor de piel", "en carne viva" o "jugarse el pellejo", verbalizamos emociones de gran intensidad; situaciones en las 
que muchas veces no podemos nombrar qué sentimos, pero si cómo nos sentimos; porque la piel es la superficie comunicadora por excelencia. Como bien decía Paul Valéry (1988): "La piel es lo más profundo que hay en el hombre, en tanto que se conoce" (p. 42). Por ello, nos daremos a la tarea de indagar un poco más sus múltiples significados, y pondremos en valor la función vital que ejerce este órgano desde la conjugación de sus múltiples dimensiones, realzando su conexión biológica con las lecturas simbólicas en el marco de nuestro discurso artístico.

En la Teoría Transcultural de las Artes Visuales, Colombres (2011) nos plantea un acercamiento al cuerpo, en tanto que superficie en la que se imprimen los sentidos y mensajes de carácter social, religioso, erótico, bélico o estético. En su análisis, basado en los aportes antropológicos de Ticio Escobar a la teoría del arte, propone cuatro dimensiones de la piel, que a favor de su lectura simbólica contribuyen a fortalecer nuestro enfoque. La primera piel es el órgano vital, ella nos viene dada de nacimiento y nos vincula al mundo natural. La segunda piel gira en torno a la vestimenta y sus variantes socioculturales. Por su parte, la tercera piel alude a los atuendos, máscaras, maquillajes y demás objetos con los que se suelen ataviar a las personas en el seno de una ceremonia ritual tradicional, por ejemplo los matrimonios, funerales, bautizos, o el uniforme del colegio. Por último, contamos con la cuarta dimensión simbólica de la piel, la cual comprende la autoexplotación de la identidad como imagen exótica, es decir, cuando dichos atuendos e inscripciones simbólicas se sacan de contexto y se exponen conscientemente como si fueran atracciones de una feria circense o simplemente con la idea de llamar la atención.

Como es sabido, la superficie gráfica de esa primera piel es la que nos ocupa en la presente tesis, sin embargo, las otras dimensiones no quedan exentas a la hora de construir el imaginario simbólico del cuerpo, son ese conjunto de pieles las que metafóricamente desdoblamos en el proceso técnico de la latexgrafía. Desde el punto de vista biológico, la piel es el órgano más grande del cuerpo humano, hace de satélite del cerebro al albergar la mayor cantidad de receptores sensoriales mediante los cuales 
percibimos el mundo -incluso desde antes de nacer- dado que las células de nuestra piel y las del sistema nervioso se origina en un lugar común: el ectodermo; de ahí que en nuestro estudio contemplamos todas las derivaciones y formas de la piel, por ejemplo: las uñas, el pelo, el cristalino de los ojos o el esmalte de los dientes. Esta perspectiva médica, nos ayuda a comprender que somos seres hápticos, porque todos nuestros sentidos se filtran a través del tacto, cada parte de nuestro cuerpo está envuelto y resguardado por el tejido de la piel.

A pesar de ello, en la cultura occidental seguimos privilegiando la visión ante los demás sentidos. Mientras el tacto implica un contacto físico, una cercanía y un encuentro que discurre empáticamente en el tiempo; la visión se ajusta a las distancias y rápidamente sigue el ritmo del bombardeo de imágenes al que estamos sujetos actualmente. Lo anterior despierta nuestro interés por materializar el contacto, en otras palabras, documentar el momento justo en que el látex liquido se vierte sobre el cuerpo, construir esa imagen matriz de la que nos habla Didi-Huberman (2015) para darle forma física a la memoria intangible a través de la huella directa. La matriz latexgráfica, se engendra en este proceso y sobre ella se transfieren con máximo nivel de detalle las texturas de nuestra epidermis.

Las marcas cutáneas son las que, desde nuestro discurso, comprenden la memoria gráfica de nuestro ser corporal. En su superficie se resguardan un sinnúmero de contenidos e inscripciones simbólicas que dan sentido a nuestra identidad. La epidermis es el documento donde se archivan tanto las marcas del envejecimiento como los acontecimientos que representan un trauma físico, como son las cicatrices y amputaciones; o bien los rastros que tienen un orden simbólico y voluntario como la escarificaciones, piercings y tatuajes. Sin embargo, cuando hablamos de identidad y piel, son las huellas dactilares -que aparecen en los primeros meses de gestación- las que nos identifican a lo largo de nuestras vidas. Todo este conjunto de signos son los que escriben la historia de cada quien; un relato que extraemos delicadamente y con métodos no tóxicos que caracterizan la latexgrafía. 
Nosotros abogamos por una imagen inclusiva, en donde las apariencias diferenciadoras expuestas en la piel queden integradas en una superficie democrática y anónima, dado que en la latexgrafía sólo se registran las topografías sensibles al tacto. Por tanto, el color, que genera controversia en personas con planteamientos racistas, queda absolutamente neutralizada en nuestro imaginario. Las pieles de látex son todas ellas similares: translúcidas, elásticas y ultradelgadas, emulando así las características formales y biológicas del órgano. La matriz latexgráfica es un trampantojo de la superficie corporal, que se expande en una imagentexto, cuya dimensión gramatical, le otorga a esta huella una fuerte carga simbólica como territorio político. Al respecto Martínez Rossi (2008) plantea lo siguiente:

En definitiva, la piel activa su sentido biológico conectándolo a su interpretación social y justo en ese proceso de enlace la piel se erige como texto simbólico. En tanto que texto, su discurso sirve de pronunciamiento político y se manifiesta como territorio de provocación e insurrección. (p. 555)

Un texto epidérmico donde se encriptan códigos que exponen tanto la singularidad individual como los rasgos de la identidad comunitaria, por ejemplo, esas marcas tribales que se graban en los ritos de interacción social o esas líneas de expresión que nos recuerdan gestos afines a los nuestros; por ejemplo, la forma de sonreír que heredamos de nuestros parientes va moldeando los pliegues de nuestro rostro curtido por el tiempo, o las callosidades y sutilezas de las manos de los adultos mayores, que atestiguan el trabajo desempeñado a lo largo de sus vidas. Lo cierto es, que, la piel nos une tanto como nos separa, es un tejido limítrofe que marca la delgada línea entre la vida y la muerte. Sin ella seríamos un desollado en carne viva. Cambiar de piel es una metáfora de regeneración, implica dejar atrás viejas máscaras, pensamientos o actitudes que nos limitaban a ser quien somos, o enmascaran quien hemos dejado de ser por encarnar otros personajes. 


\subsubsection{ENTRE LA MUDA Y EL DESOLLADO}

Al igual que muchos animales, los seres humanos mudamos de piel, solo que en nuestro caso este proceso sucede a diario, de forma imperceptible e indolora, incorporando en la nueva superficie los signos del envejecimiento y manteniendo intacto el patrón de las huellas dactilares (Fig. 2.1). Este factor biológico es crucial en nuestra investigación, dado que al trasferir la huella de la piel en el molde y/o matriz de látex, imprimimos una prueba de estado del cuerpo, un fragmento de memoria donde se documenta la historia de resiliencia de cada quien. Así, simulamos técnicamente lo que sería una muda animal, un cambio de piel que es en suma una regeneración propia de la vida.

Fig. 2.1. Muda: momento en que un voluntario desprende su huella latexgráfica de su piel. 

Entre la muda y el desollado; en esa tensión se encuentra nuestro trabajo, todo depende de la connotación personal e íntima que se le otorgue al proceso técnico y su devenir ritual. A diferencia de la muda, que es una acción biológica e involuntaria, el desollamiento implica una acción violenta y consciente que desgarra la piel del otro, dejando su cuerpo expuesto en carne viva. En diversas culturas la figura del desollado ha jugado un papel importante en ritos y sacrificios sociales, tal es el caso de la ceremonia mesoamericana al dios Xipe Tótec (En la lengua en Náhuatl xipe totec significa "nuestro señor desollado") (C.1350-1521) cuya ofrenda consistía en despellejar al sacrificado para vestir -con esta nueva piel- a su deidad, y así, asegurar la prosperidad y fertilidad que el manto epidérmico le confería simbólicamente (Fig. 2.2). En cambio, en la cultura occidental: "El desollado ocupa un lugar especial en la historia de las perforaciones del cuerpo como frontera. La práctica representa la síntesis mas extrema del castigo capital (tortura) y la producción de conocimiento médico" Claudia Benthien (2002, p. 61). Por ejemplo, en la herencia clásica tenemos la figura mitológica del sátiro Marsias despellejado vivo, y en el marco del imaginario cristiano, la tradición de los santos mártires desollados.

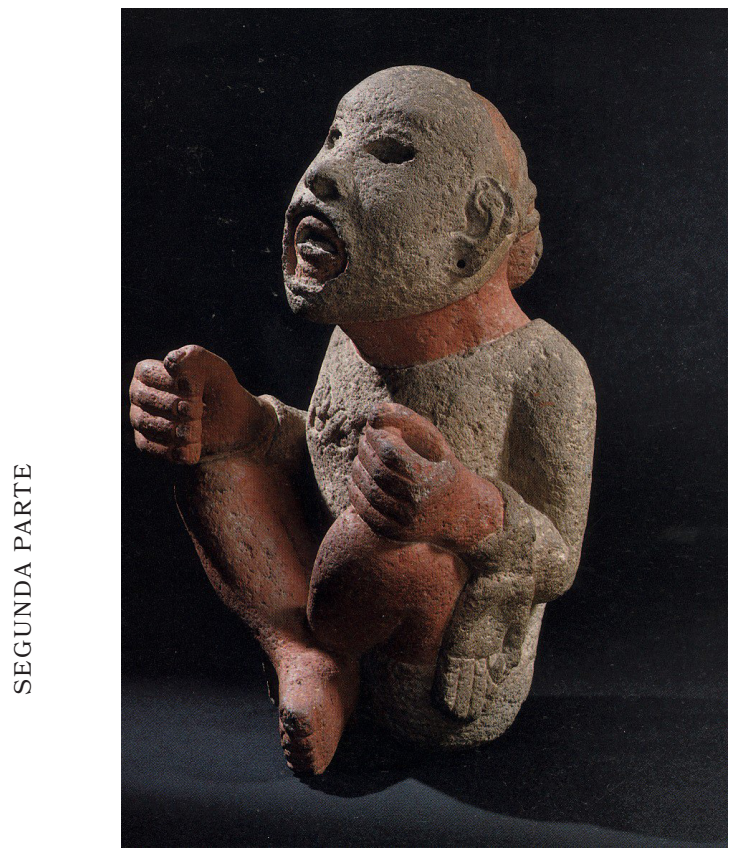

Fig. 2.2. Xipe Tótec, talla en piedra policromada del dios azteca, C.1350-1521 
Cuenta la leyenda que el sátiro Marsias fue despellejado vivo por retar al dios Apolo, en este caso, el desollamiento es un castigo capital, tal y como se aprecia en el grabado de Giovanni Stradanus Apolo desollando a Marsias (1580-1600); imagen en la que el cadáver del sátiro yace atado a un árbol, y a sus pies cae el mono -casi completo- de su piel (Fig. 2.3). Esta labor se representa como un acto de meticuloso cuidado, la piel se corta con el pulso de un cirujano en ausencia de sangre o fluidos. Prevalece una tensión sádica entre lo brutal y la estética teatral. El cuerpo en carne viva queda paradójicamente intacto, su musculatura se aprecia a la perfección, haciendo referencia a los estudios anatómicos propios de la época. En síntesis, al sátiro Marsias no sólo se le ha quitado la vida, sino que también se le ha desgarrado la identidad que encarnaba su piel. En tanto, su cuerpo pasa al anonimato de la carne, que lejos de subirlo al olimpo de los dioses le recuerda la vulnerabilidad de su humanidad.

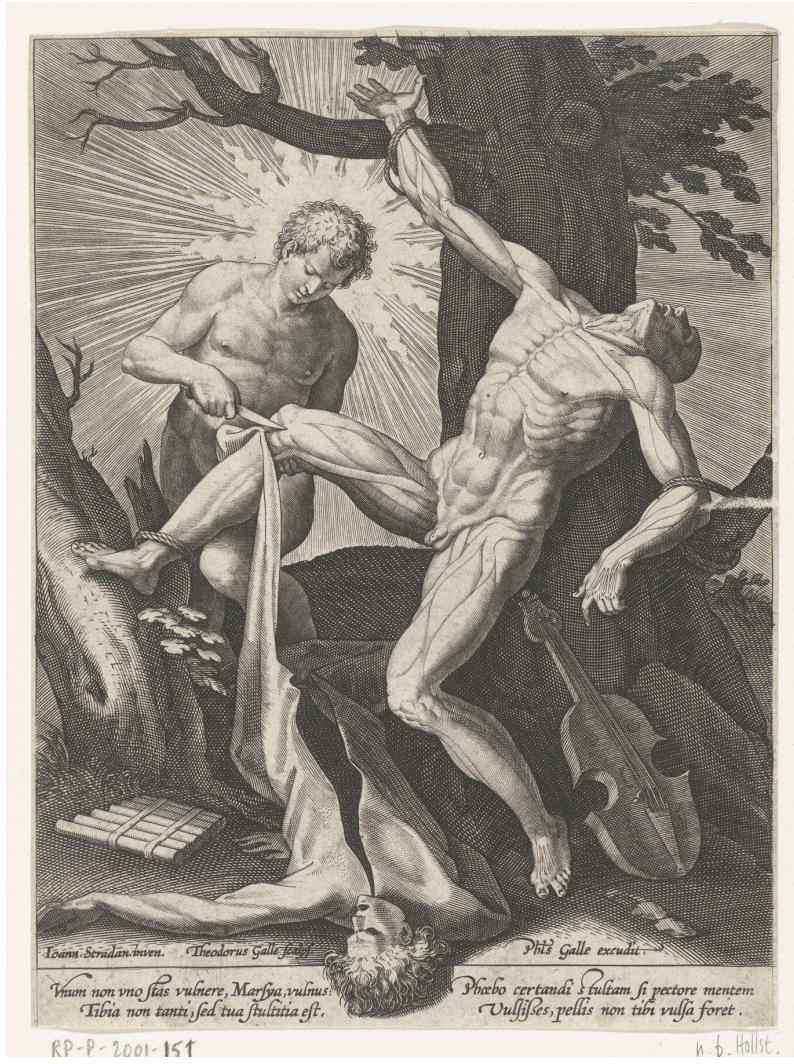

Fig. 2.3. Giovanni Stradanus, Apolo desollando a Marsias, huecograbado, 1580 1600 
Por otra parte tenemos las ilustraciones científicas en las que confluyen los relatos religiosos con los estudios anatómicos, como en el caso del martirio de San Bartolomé, en la que este personaje muestra -con cuchillo en mano- la piel colgante de su cuerpo, a manera de recompensa y señal triunfal del conocimiento pleno que le otorga la perspectiva cartesiana y la fe incuestionable. Podemos identificar esta figura en el grabado de Juan de Valverde de Hamusco, Historia de la composición del cuerpo humano (1556), en la que el apóstol, alejado del martirio, se erige como una metáfora de poder (Fig. 2.4). Una imagen potente que en nuestra contemporaneidad ha servido de referencia para que Gunther von Hagens y su grupo de investigación, realicen múltiples plastinaciones desde finales del siglo XX, utilizando cuerpos humanos, como en la obra titulada The skin man (El hombre piel), en las que mezclan las técnicas anatómicas de vanguardia con el arte, en una controvertida puesta en escena denominada Body Worlds (Mundos Corporales). En ambos casos el cuerpo resulta el objeto de estudio, y la piel la superficie de inscripción y reconocimiento de la identidad individual y social (Fig. 2.5).

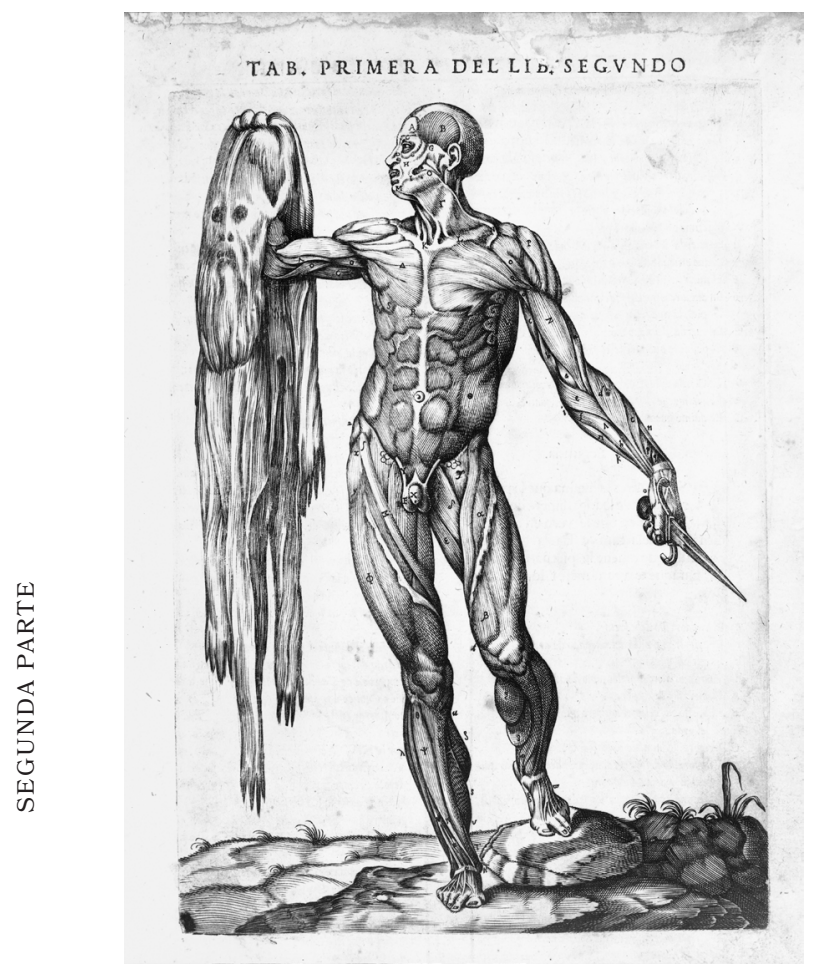

Fig. 2.4. Juan Valverde de Hamusco, Historia de la composición del cuerpo humano, xilografía, 1556. 


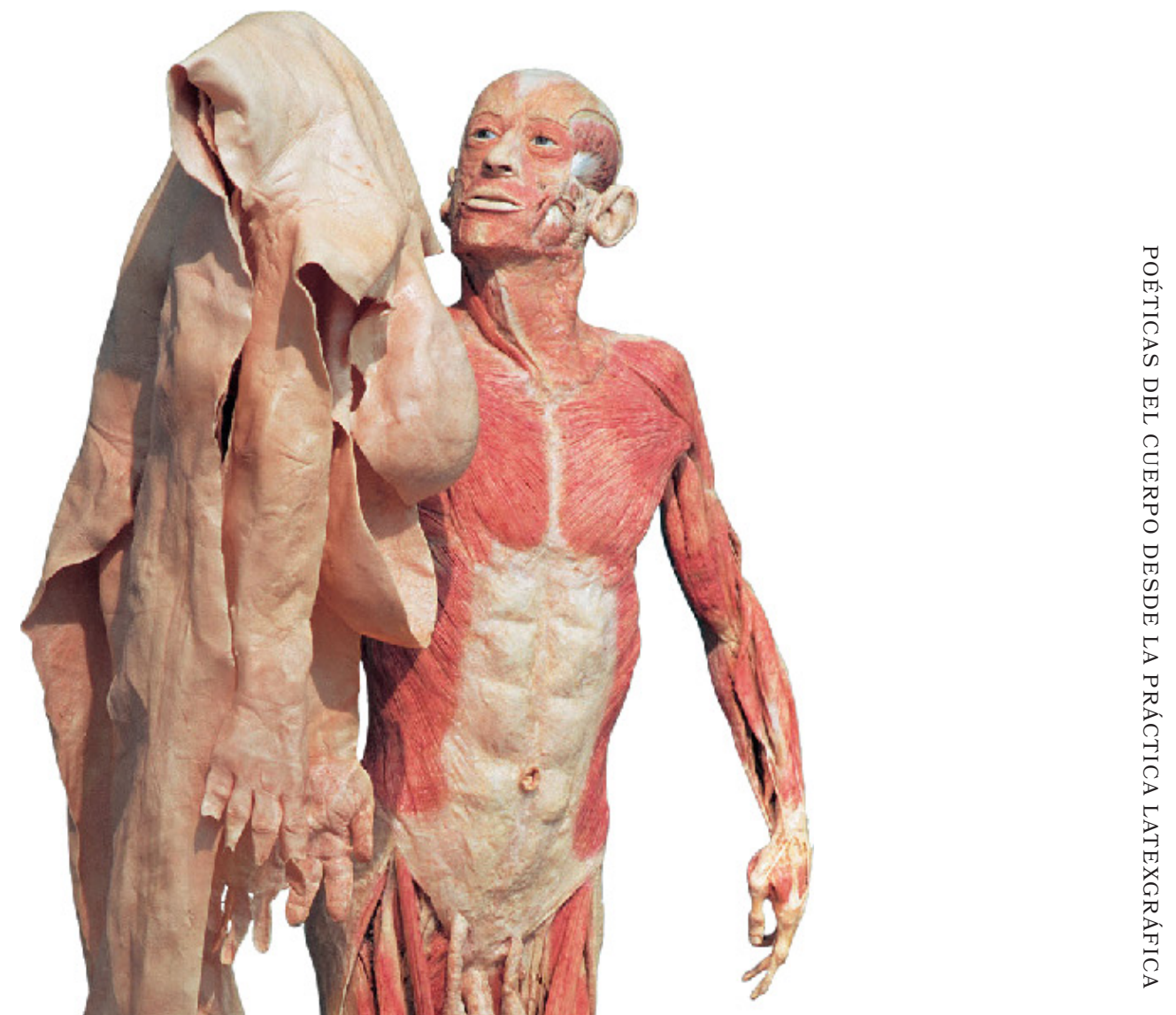

Fig. 2.5. Gunther von Hagens,

Skin man, Institute for

Plastination, Heidelberg,

Alemania

Finales del siglo XX 
Ya sea por una motivación científica, ritual o castigo, al arrancar la piel del cuerpo el significado de lo humano queda expuesto en carne viva; se abre al mundo nuestra condición más vulnerable, biológica y finita. Se pone en evidencia la tensión que también prevalece en nuestro trabajo, esa que correlaciona la razón cartesiana con lo orgánico, fluido y abyecto del cuerpo. Para ejemplificar este enfoque nos gustaría citar el video titulado The Skinless Model of Liberty (El modelo sin piel de libertad) (2013), de la artista francesa conocida como Orlan. En esta obra, presentada en el marco de la Biennale de Venecia del mismo año, la autora se aleja de las intervenciones quirúrgicas a las que solía someterse, para construir un desollado virtual a partir de imágenes 3D de su cuerpo (Fig. 2.6). Al deshacerse de la piel desaparecen también las interfaces con el mundo que en ella se encarnan, exponiendo una frágil y vulnerable forma de libertad (Orlan, 2014).

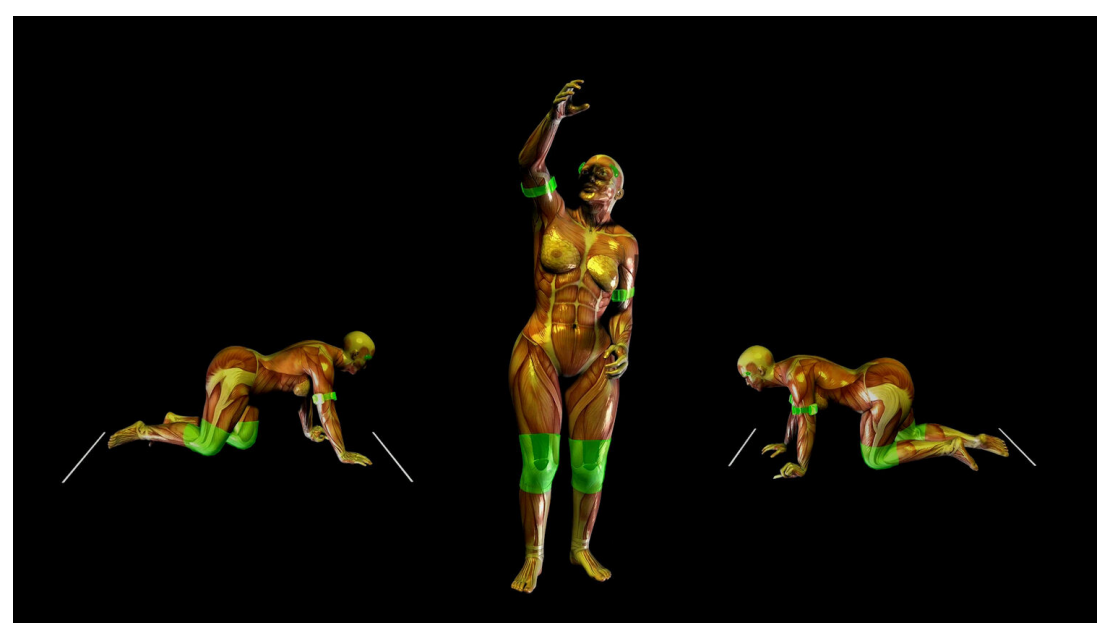

Fig. 2.6. Orlan, Skinless Model of liberty, performance audiovisual , 2013 
Esta idea de arrancarse la piel a pedazos es un intento desesperado de la persona para deshacerse de los estigmas que lleva grabados simbólicamente sobre su epidermis, para evidenciar y sacar a relucir lo que íntimamente se padece y públicamente se recrimina. Así, siguiendo la tónica de Orlan, la reconocida artista vasca Itziar Okariz nos plantea una acción donde se construyen y deconstruyen los imaginarios en torno al cuerpo, su identidad y la relación con el espacio social. De esta manera, en la serie de imágenes tituladas Bodybuildinǵ (1994), se ve como Okariz se viste y/o desviste de una segunda piel de látex, fragmentos de caucho que pueden estar siendo vistos de adentro hacia fuera o al revés, depende de la perspectiva con que se mire, pero ante todo la ambigüedad de esta escena es lo que prevalece para debatir los discursos de género, poder y subversión encarnados en la piel (Fig. 2.7). El cuerpo como signo y materia plástica son dos conceptos que nos vinculan a esta obra, la idea de la muda de piel o autodesollamiento, es una experiencia individual que se documenta y comparte con el público para activar su reacción.
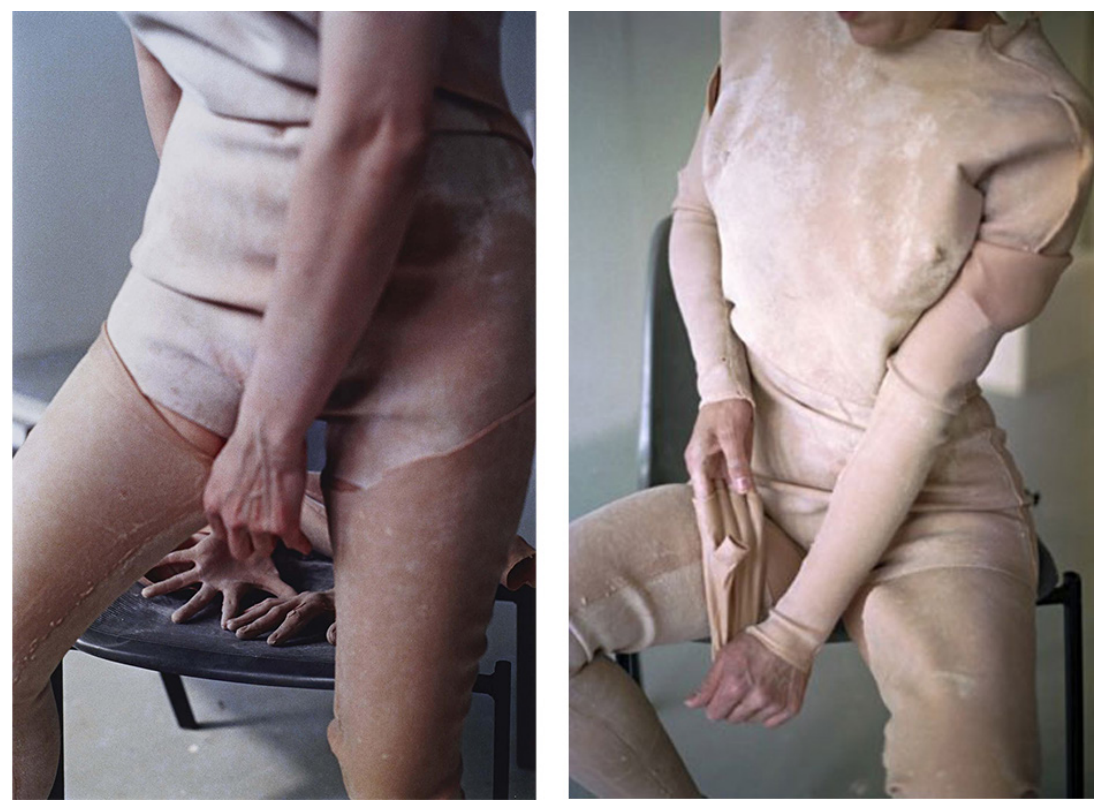

Fig. 2.7. Itziar Okariz, Bodybuilding, prótesis de látex, performance y fotografía, (1994) 
Por último, y no menos importante, se encuentra el corpus de obra de la artista brasileña Helena Kanaan, quien articula, desde la gráfica expandida, un discurso que conjuga la tradición de la técnica litográfica con la elaboración de pieles de látex, objetos que hacen de soporte para imprimir las texturas acuosas y grasosas, que previamente ha grabado sobre las piedras. En un complejo entramado, los pellejos de látex son concebidos metafóricamente como un cuerpo desgarrado y reducido a su piel, que sirve también de superficie receptora y frontera simbólica entre lo humano y la naturaleza. En las improntas matéricas, la artista mezcla papeles japoneses con otras texturas y pigmentos, haciendo que las mismas tengan una apariencia provocadoramente visceral. En su serie titulada Policuerpos (2011-2012) (Fig. 2.8), repiensa las fronteras del grabado y del cuerpo-piel, mediante las cualidades intrínsecas de la materia, fusionando dos componentes naturales, por un lado la superficie porosa y rígida de la piedra litográfica, y por el otro el látex, como material orgánico cuya naturaleza se transforma en el proceso de secado, y pasa ser un cuerpo maleable, elástico y sugerente.

Para Kanaan, sus pieles de látex son una metáfora del cuerpo humano y su inestable constitución. Parte desde la poética del proceso de extracción de esta sustancia, la cual es una savia que proviene del interior del árbol, a manera de fluido corporal, como si fuera la sangre que se coagula con el tiempo. Esta continua metamorfosis, y sus múltiples posibilidades expresivas es lo que conduce a la brasileña a construir sus tejidos, capa a capa, incorporando improntas y otros materiales, hasta conformar una piel elástica pero frágil a su vez. La disposición de las piezas no remite a la unidad convencional del cuerpo, sino, por el contrario, a su devenir informe y liminal. Tal y como si fueran cueros curtidos por el tiempo, Kanaan los despliega y estira hasta el punto del desgarro. En un juego poético, entre la artista y la materia, la delicadeza de sus imágenes contrasta con lo grotesco de las apariencias. En tanto, si bien estas pieles no son un registro del cuerpo, como sí lo es en nuestra práctica, si representan los mismos intereses en torno a la condición humana en el mundo ficcional en el que nos invita a ser parte. Cuerpos expuestos 
hacia afuera, armonizados con el espacio gracias al juego lumínico que traspasa estas membranas. En sus propias palabras ${ }^{6}$ :

Los Policuerpos son cuerpos híbridos, que contienen las subjetividades y las objetividades provocadas por el procedimiento litográfico y por el látex, que es savia, circulación y también, piel, membrana, película. Un cuerpo local, frontera entre profundidad y superficie donde aparecen las marcas, los pliegues, las acumulaciones, las cicatrices y los desgarros. Policuerpo porque es unión, confluencia, y porque es cuerpo informe. El policuerpo asume individualidad y pluralidad, se hace unidad y totalidad, cuerpo excesivo, cuerpo temporal, piel, cuerpo, cuerpo metástasis, entre otras nomenclaturas que plantea a lo largos de sus transformaciones. (Kanaan, 2011, p.82)

Al igual que se regeneran continuamente nuestras células epidérmicas, nosotros creemos que los imaginarios simbólicos también deben hacerlo. Así, desde la latexgrafía podemos construir un universo ficcional que nos permite mudar de piel y re(conocernos) en una nueva imagen, o bien desollar los miedos que nos curten y nos impiden aceptar sin prejuicios la diversa corporalidad. Al desdoblar la imagen encarnada en la piel, confrontamos su apariencia más fáctica con los estereotipos y personajes que se habían apropiado de nuestra autopercepción.

Por tanto, la muda es un rito de sacrificio y redención mediante el cual se despellejan, purgan, limpian y regeneran los imaginarios en torno al cuerpo propio y la construcción de la alteridad en el tejido social. "La huella corporal lleva el sufrimiento a la superficie del cuerpo, allí donde

\footnotetext{
${ }^{6} \mathrm{El}$ texto original ha sido escrito en portugués y fue traducido por Luis Diego Muñoz con la aprobación de la autora:

Policorpos são corpos híbridos, que contém as subjetividades e as objetividades provocadas pelo procedimento litográfico e pelo látex, que é seiva, circulação e, também, pele, membrana, película. Um corpo lugar, fronteira entre profundidade e superfície, onde aparecem as marcas, as dobras, os acúmulos, as cicatrizes e os rasgos. Policorpo porque é junção, confluência, e porque é corpo sem forma fixa. O Policorpo assume individualidade e pluralidade, se faz unidade e totalidade, corpo excessivo, corpo temporal, pele-corpo, corpo metastásico, entre outras nomenclaturas que suscita ao longo de suas transformações. (Kanaan, 2011, p.82)
} 


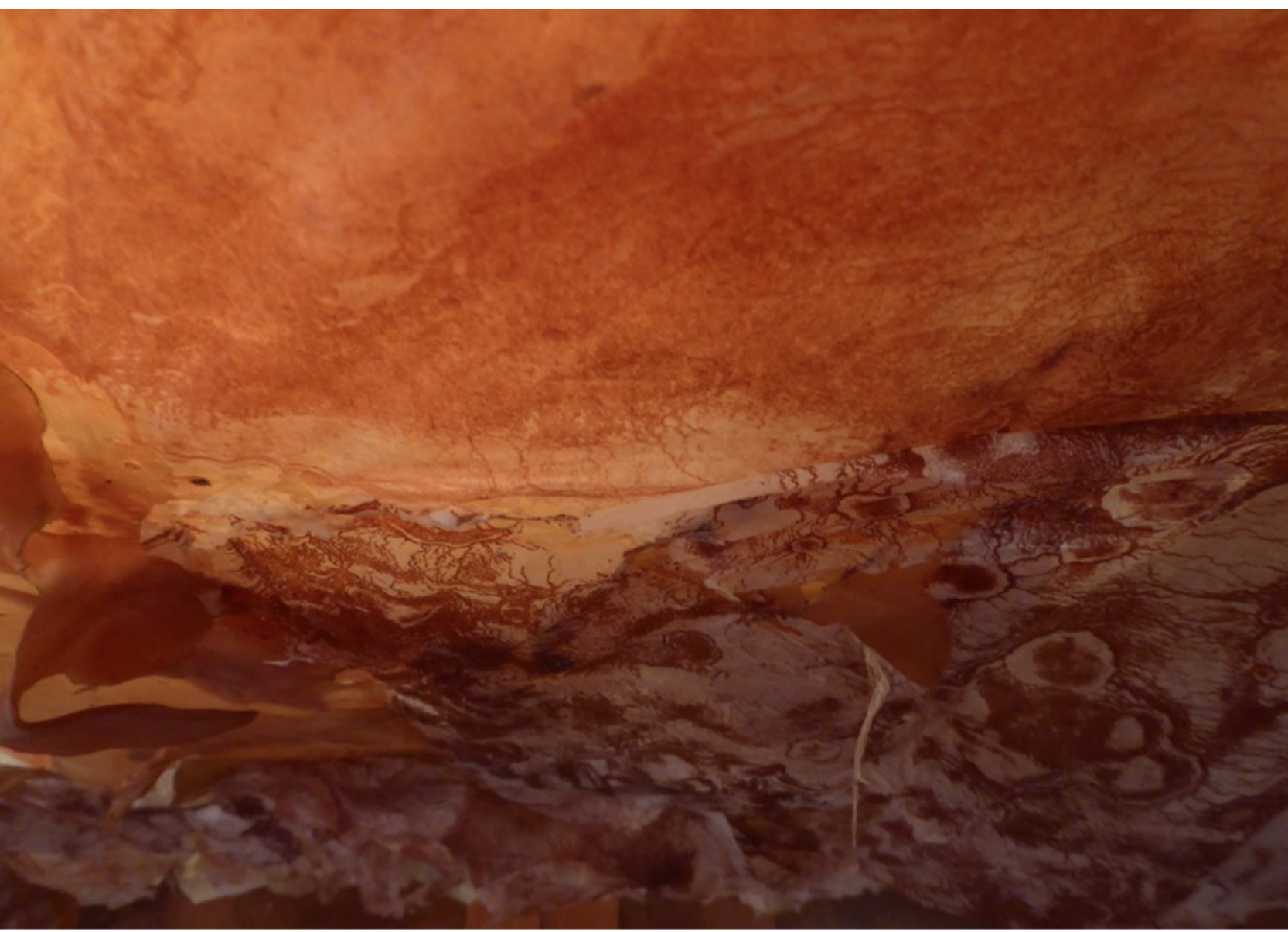

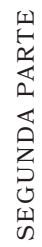

Fig.2.8 Helena Kanaan, Policuerpos,

Instalación con latex, 2011-2012 (Detalle) 
se hace visible y controlable. Se extirpa de una interioridad que aparece como un abismo" (Le Bretón, 2017, p. 58). Pero, al margen de toda apreciación técnica o lectura simbólica, creemos que lo que hay detrás de cada impronta epidérmica es un documento probatorio, una suerte de testimonio visual de un aquí y de un ahora, que es ante todo un indicio de una persona que cedió voluntariamente un fragmento de la historia escrita en su piel para ser parte del presente proyecto.

documento hemos agrupado nuestros referentes específicos en torno a dos ejes: Huellas del tiempo y Fraǵmentos de memoria, pero estas categorías de análisis lejos de encasillar las imágenes en uno u otro grupo, tienen una frontera absolutamente permeable, ya que existen conexiones discursivas y formales que las unen bajo una misma piel; de modo que enfatizaremos los puntos comunes entre este corpus de obras y el nuestro a la luz de los conceptos anteriormente citados.

Como hilo conductor destacamos la utilización del cuerpo como medio, soporte y matriz expresiva, propiamente aquellas obras en cuyo proceso se resguarda la integridad física de la persona, evitando o minimizando la violencia infringida directa o indirectamente sobre el cuerpo al entrar en contacto con otras superficies. Como ya hemos mencionado en capítulos anteriores, desde nuestro enfoque creemos que no hace falta "arriesgar el pellejo" para estimular una experiencia háptica y estética, despertar la empatía o provocar una reflexión que nos ponga "la piel de gallina”. Por esta 
razón utilizamos la ficción lúdica como estrategia creativa para que sea la imaginación el espacio donde las obras adquieran múltiples significados, y el proceso de la latexgrafía el lugar de encuentro entre el público y el artista. Como bien destaca Jennifer L. Roberts en la reciente conferencia Contact: Art and the Pull of Print. Part 1: Pressure; si entendemos el grabado como un arte de contacto, cada impronta es el resultado de la presión ejercida para trasferir la imagen de una superficie a otra; esto nos permite ahondar la dimensión multisensorial que encarnan las imágenes impresas, a través del sentido social del tacto y la intimidad o la violencia que evocan (National Gallery of Art, 2021).

\subsubsection{HUELLAS DEL TIEMPO}

La huella es tanto una evidencia del contacto físico como un rastro emocional intangible. En ambos casos siempre encarna un proceso de transferibilidad entre dos realidades que han entrado en contacto en un espacio-tiempo. El contacto lo comprendemos como el acto de tocar y ser tocado tanto física como afectivamente, por lo que la dimensión metafórica y conceptual de la huella lleva consigo la experiencia háptica, la tensión entre la presencia-ausencia, la matriz-soporte y la memoriaolvido, así como la temporalidad. En una sociedad en la que el tiempo se ha acelerado tendemos a borrar el rastro que nos trajo hasta aquí, porque nuestros sentidos están en todas partes y en ninguna del todo. Hemos ido perdiendo el contacto directo con el mundo y nuestra memoria corporal se ha ido entumeciendo.

Las huellas del tiempo remiten a la importancia de la espera, a la valorización del proceso del arte y de la vida misma. En el marco de nuestra práctica, el látex tarda aproximadamente de 15 a 20 minutos en secar, tiempo suficiente para que la persona se detenga y sea consciente de un pequeño fragmento de su memoria corporal, y cómo la materia se transforma dejando grabado la huella de su piel en un soporte expresivo. Como afirma Pallasmaa (2018), la lentitud se asocia con el recuerdo y la velocidad con el olvido, la aceleración vertiginosa de nuestra sociedad nos está conduciendo a una amnesia cultural. El contacto físico y la 
experiencia háptica poco a poco se van desvaneciendo, sin embargo, en la gráfica contemporánea cobran más relevancia que nunca debido precisamente a su carácter urgente y primigenio, tal y como lo apunta Mínguez García (2012):

Al final, creemos que independientemente de cómo se haya venido desarrollando la gráfica múltiple en términos de apariencia a lo largo de los siglos, aquello que ontológicamente no ha variado, es precisamente la relación dialógica existente entre la matriz (único) y la copia: a nivel teórico-conceptual respecto a su grado de interdependencia axiológica (...) y a nivel "práctico", una relación que no podría existir sin la idea del contacto. (p.85)

El vínculo entre la acción y la impronta corporal tomó fuerza desde la segunda mitad del siglo XX en las corrientes artísticas de posguerra donde se incorpora al proceso como parte constituyente de la obra, por consiguiente, la huella encarna la relación fenomenológica de copertenencia con el mundo. En consecuencia, Candiani (2018) plantea que a partir de este momento los artistas han sacado provecho de la versatilidad del cuerpo para emplearlo como matriz y/o soporte, atendiendo a la idea de documentar el registro de su huella como testimonio de sus acciones más que a la reproducción en sí, de modo que se transgreden los límites tradicionales entre la matriz como elemento activo y la copia como elemento pasivo. La obra es un resultado de la acción repetitiva de dejar huella. La impresión, es por tanto, el testimonio visual que se construye en este acontecimiento.

Por ejemplo, en la serie Antropometrías (1960), el célebre artista francés Yves Klein convirtió el cuerpo de las modelos desnudas en un sello humano y a su persona en el director de este performance (Fig. 2.9). Los cuerpos - previamente cubiertos con pigmento azul- imprimen su huella sobre el lienzo, mientras les acompaña una orquesta y el público expectante. Las imágenes de este proceso carecen de rasgos de identidad reconocibles, puesto que el volumen corporal impide que se registren los detalles de la piel, por lo que a menudo sólo hay constancia de rastros con indicios corporales. 
En sintonía con su enfoque, en la mayoría de los trabajos, nosotros no tenemos la intención de retratar a la persona que originó la huella corporal, de modo que la impronta puede leerse como un símbolo democrático de la forma y experiencia humana. Otro punto en común es la dimensión performática como una acción participativa, en la que el artista marca la pauta, pero el resultado final es fruto del devenir experimental, ya que es el propio proceso el que se documenta en distintos soportes, como, por ejemplo: el lienzo, la fotografía o el vídeo. El cuerpo pincel o sello, también deviene en cuerpo matriz, módulo y patrón. No hay dos antropometrías idénticas, como tampoco tenemos dos huellas latexgráficas iguales, aunque sean las mismas personas porque el material elástico que utilizamos como matriz nos permite jugar con la variabilidad de las improntas.

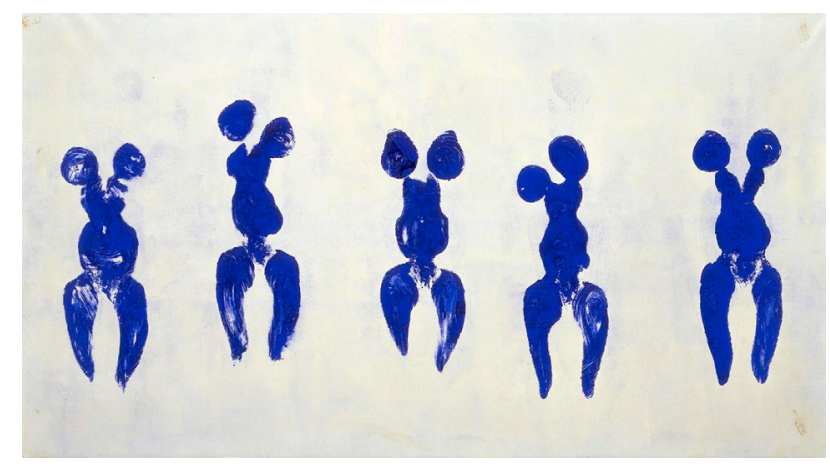

Fig. 2.9. Yves Klein, Antropometrías, Impresión corporal, Performance, (1960)

Por su parte el artista afroamericano David Hammons realiza la serie de improntas corporales Body prints durante la década de los 60 y principios de los 70, utilizando su cuerpo como matriz e instrumento político para dejar -literalmente- su huella en un contexto en el que los disturbios raciales hervían en las calles (Fig. 2.10). Así, la impronta del artista representa un acto de empoderamiento, para dejarse ver en un panorama social que invisibiliza a las minorías. Desde la mayor austeridad y utilizando recursos cotidianos, el estadounidense se embarra de mantequilla, cubriendo por completo su cuerpo y vestimenta, para utilizar este medio graso como tinta invisible para imprimir su cuerpo directamente sobre el papel o cartón. Una vez dejada la huella grasienta, 
Hammons esparce polvo de grafito sobre la superficie impresa para que este se adhiera a la película grasa y así registrar nítidamente la imagen, en la que se pueden apreciar detalles de texturas de la piel, cabello y ropa, al mismo tiempo que se desvanece la figuración en una mancha abstracta. Gracias a la poética de la materia y del proceso técnico, nos recuerda las formas de registrar y documentar las huellas dactilares en la medicina forense. Estos y muchos otros rasgos nos hacen confluir en torno a su trabajo, sin embargo, el que más es quizá la conceptualización del proceso y el delicado balance entre lo abyecto y la estética delicada, entre la abstracción y la hiperrealidad, entre el medio y el mensaje, donde no hay un detalle que sea gratuito.

Fig. 2.10. David Hammons, ST, serie Body prints, Impresión corporal con materia grasa y polvo de grafito sobre papel, 1969.

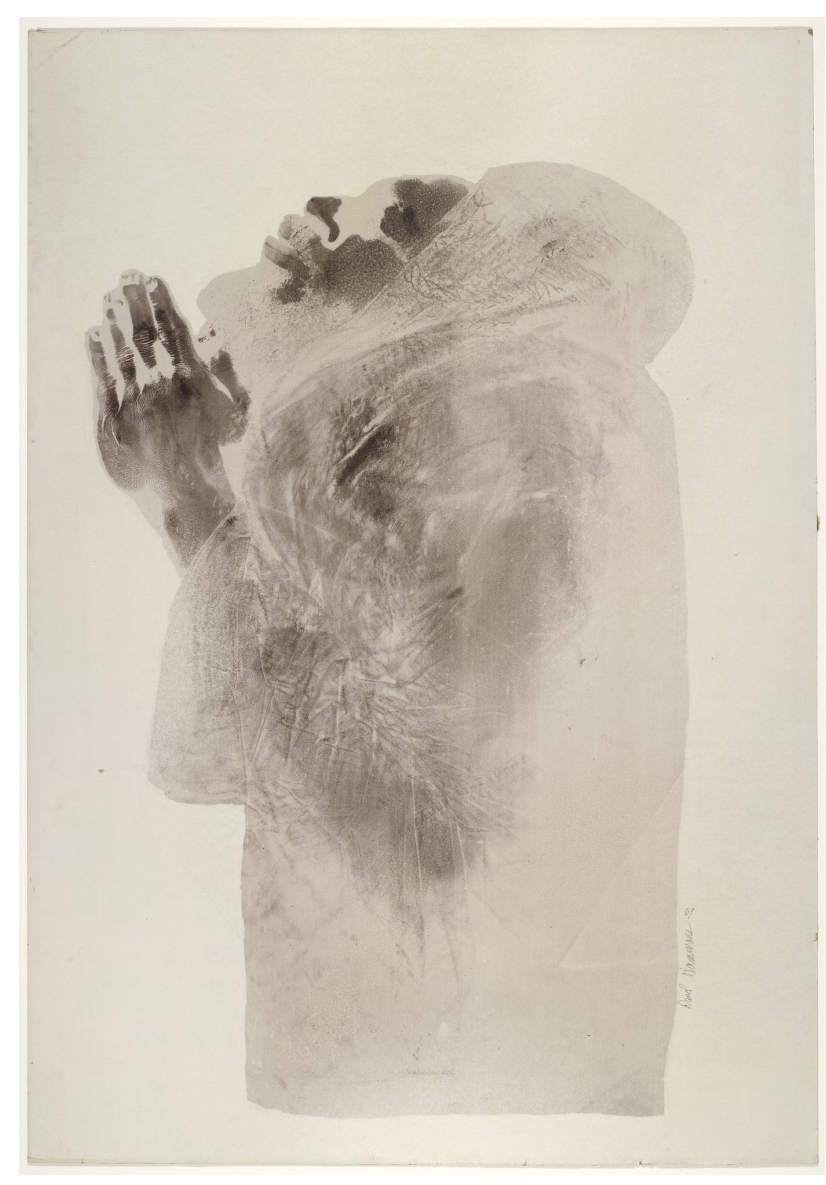


Por su parte, la icónica artista cubana Ana Mendieta, en el marco de los discursos feministas y las prácticas del body-land art también utilizó el cuerpo propio como instrumento político, en su caso para problematizar la condición de ser mujer y migrante en una sociedad hegemónicamente patriarcal y racista. Su piel se funde con la tierra, ambas consideradas superficies de una misma naturaleza. Los performances abarcan dimensiones polifacéticas en las que entrelaza la política e identidad, con lo ritual y lo místico. Uno de los grandes aportes del legado de la artista a nuestra investigación gira en torno a la concepción del cuerpo como matriz reversible y el proceso artístico como ritual significante. Tal y como vemos en la serie Siluetas (realizada entre 1973 y 1977 en México), su cuerpo se expande en el espacio a través de las huellas registradas con fuego, piedra, flores, arena o sangre; siluetas realizadas tanto en positivo como en negativo (Fig. 2.11). El material y la alquimia cobran un valor poético y simbólico en esta ceremonia artística, en la que -en cuerpo

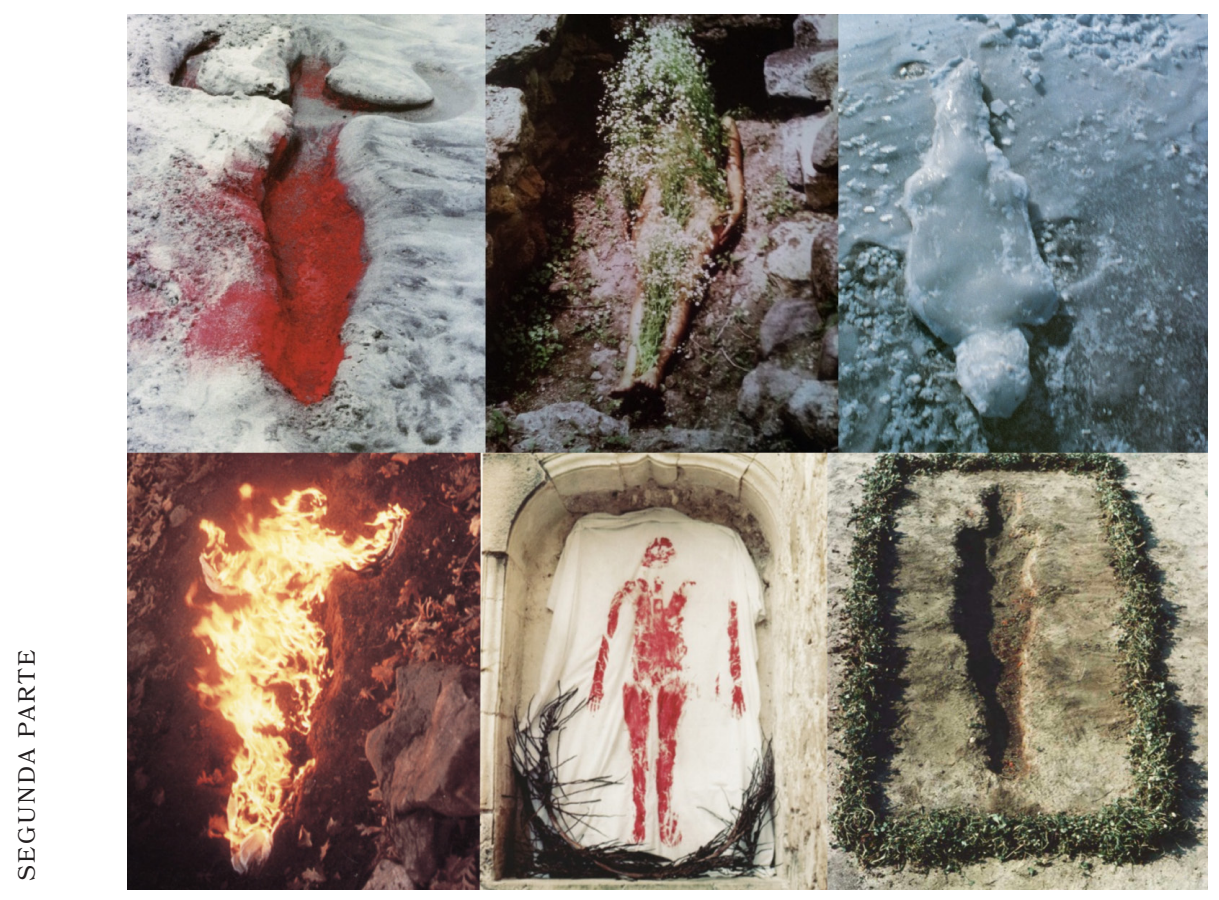

Fig. 2.11. Ana mendieta, serie de Siluetas, performance y registro fotográfico, (1973-77) 
presente-, Mendieta evoca una ausencia rotunda, de la cual sus siluetas capturadas fotográficamente, perviven décadas después de su prematura muerte. Tras los pasos de Mendieta encontramos la acción ¿Quién puede borrar las huellas? (2003) llevada a cabo por Regina José Galindo en la Ciudad de Guatemala, en la cual la artista utiliza sus pies descalzos como matrices vivas para apelar a la frágil y manipulada memoria histórica. En completo silencio y con tono casi litúrgico, sumergía sus pies en un tazón lleno de sangre que llevaba consigo para imprimir las huellas de su trayecto (Fig. 2.12). Un camino de violencia que motiva a Galindo a encarnar el cuerpo de los compatriotas que han sido asesinados, silenciados y desaparecidos sin dejar rastro, a causa del genocidio perpetuado en su país. En la misma región, pero con realidades distintas, destacamos la obra del artista costarricense Javier Calvo, quien utiliza su piel como receptora de impresión y el sol como mordiente, en la obra titulada DIS (2013), usa una plantilla para grabar temporalmente la forma del mapa centroamericano sobre su blanco y desnudo pecho (Figs. 2.13 y 2.14). La técnica es simple, a más exposición a los rayos UV más oscura se torna la piel; luego el artista documenta fotográficamente la regeneración de la quemadura, en la que paulatinamente se muda la piel y con ello
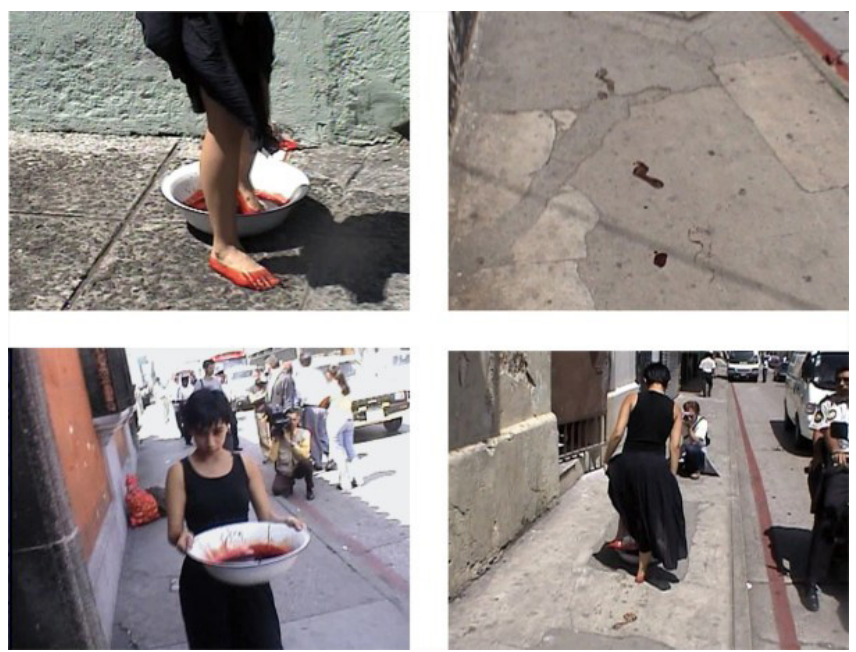

Fig. 2.12. Regina José galindo, ¿Quién puede borrarlas huellas?, Performance y registro audiovisual, (2003) 
se borra la impronta solar, en un proceso de despigmentación. En esta acción el artista utiliza la dimensión epidérmica del cuerpo como espacio de confrontación en torno al concepto de "lo centroamericano" a partir del enfoque de otredad y diferencia que se establece desde Costa Rica; país en el que la blancura sigue siendo un mito que -para algunos- nos sitúa del lado "privilegiado" de la civilización y de la colonia. Desde estas reflexiones artísticas, podemos destacar que los constructos imaginarios ligados a la identidad, el poder y la colonia, siguen vinculados al color de piel. La memoria histórica corre un peligro inminente si no recordamos y rescribimos esos relatos críticos. Desde nuestra investigación, el color queda neutralizado en la huella latexgráfica, ya que el molde sólo registra las texturas táctiles de la piel que luego reimprimimos sobre otros materiales y en escala de grises. Nuestra intención es democratizar la impronta humana, tomando como punto de partida tanto las características de la latexgrafía como la dimensión biológica del cuerpo, ya que al igual que pasa en la naturaleza, nuestros moldes hacen la función de una muda, y en este proceso únicamente se desprende la capa externa de la epidermis, en la que no hay pigmentación. Por esta razón,
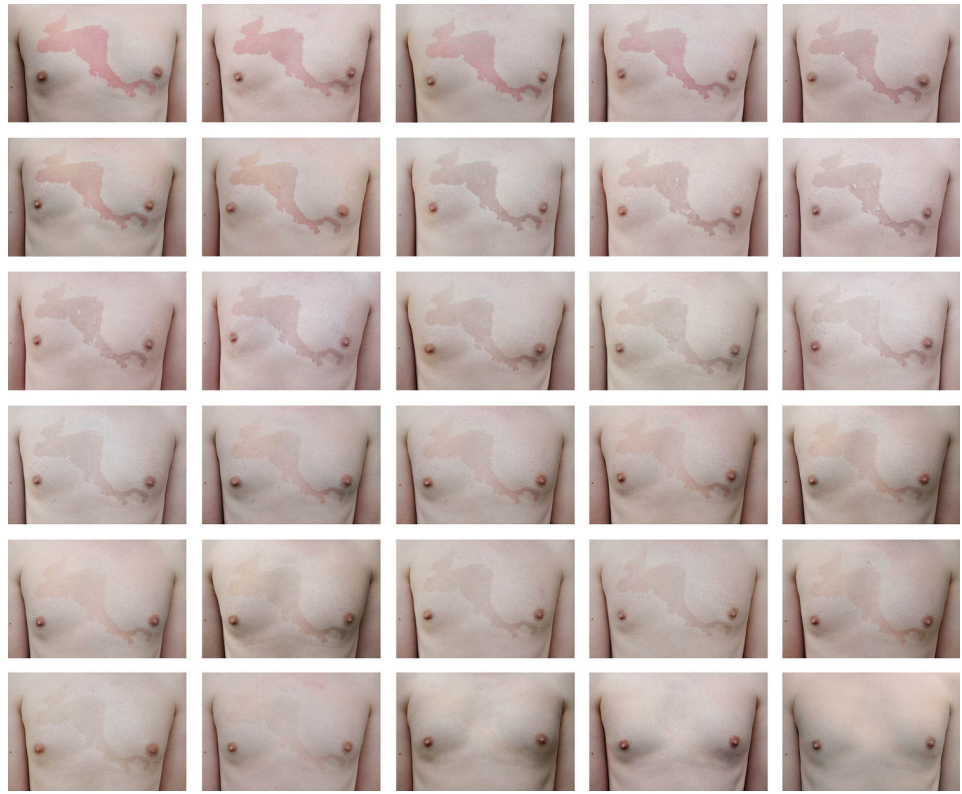

Fig. 2.13. Javier Calvo, DIS, Impronta solar sobre piel y fotografía, (2013) 
nos sentimos identificados con la obra Galindo, ya que escoge la sangre como pigmento común a todos, y con la de Calvo porque tanto a él como a nosotros nos une el sentido de la piel como superficie de inscripción simbólica, si bien planteamos un enfoque distinto: en su caso, expone el color como un factor diferenciador, en cambio, en nuestra propuesta, la huella de la piel es translúcida y encarna un discurso inclusivo, ya que sin importar la etnia, género, política o religión, la piel nos envuelve a todos por igual, por ello valoramos la escala de grises como la escala de valores en la que se dispersa el juicio y prejuicio humano.

Fig. 2.14. (Detalle) 
La participación insitu de la población como parte del proceso creativo es un factor determinante en nuestro quehacer artístico, puesto que sin la donación voluntaria de las matrices latexgráficas no tendríamos proyecto. Bajo este enfoque nuestro "taller" se expande a las calles e instituciones culturales en las que se desarrollan las jornadas de recolección de moldes, las cuales se insertan en el marco de la sensibilización y educación artística para promover que la audiencia tome un rol activo. De esta manera el público es parte del proceso y el arte se transforma en una acción participativa, en la que el cuerpo de la artista se expande y diluye entre la multitud. Por ello, experiencias artísticas como la que nos planteó Tania Bruguera bajo el título 10.142.926, llevada a cabo en el Turbine Hall del Tate Modern (de octubre del 2018 a febrero del 2019), es un referente importante para la presente investigación (Fig. 2.15). Tal y como alude su nombre, esta instalación hace referencia a una cifra: la cantidad de personas que migraron sumadas al número de fallecidos por esta causa en un año. Un número que nos encara con el riesgo asociado a la migración masiva y la pérdida desapercibida de vidas. Ante esta normalización del drama humano, Bruguera propone varias estrategias artísticas para conectar empáticamente a la audiencia con la realidad.

Pero, ¿cómo lo logra? Por ejemplo, cada visitante que ingresó en el recinto se llevó impreso el nombre de la exposición en su piel a manera de tatuaje efímero, un acto que indudablemente nos recuerda los horrores del Holocausto y sitúa a la persona en contexto. Esta primera toma de contacto con la realidad se acrecienta cuando el público entra en la sala, que aparentemente sólo tiene un suelo negro que cubre por completo la superficie; sin embargo bajo esta cobertura -sensible al calor- se oculta el retrato de un joven sirio llamado Yousef, como símbolo de las millones de personas "invisibles" que conforman la cifra. Bruguera hace uso del contenido que emana del material y la disposición del espacio en el que el público transita. El rostro del joven no se hace visible hasta que las personas voluntariamente dejan su rastro corporal impreso en el suelo, el cual momentáneamente se torna blanco al contacto y permite exponer parcialmente fragmentos de la imagen que yace oculta. Por tanto, se conjuga el factor técnico con el discurso, dado que se requiere- 
literalmente-de más calor humano para que el material sensible revele lo que esconde. En otras palabras, el cambio sólo sucede si co-accionamos socialmente, si voluntariamente sumamos nuestra huella a la de los demás, y con ello, percibimos la cara humana que ocultan los fríos datos.

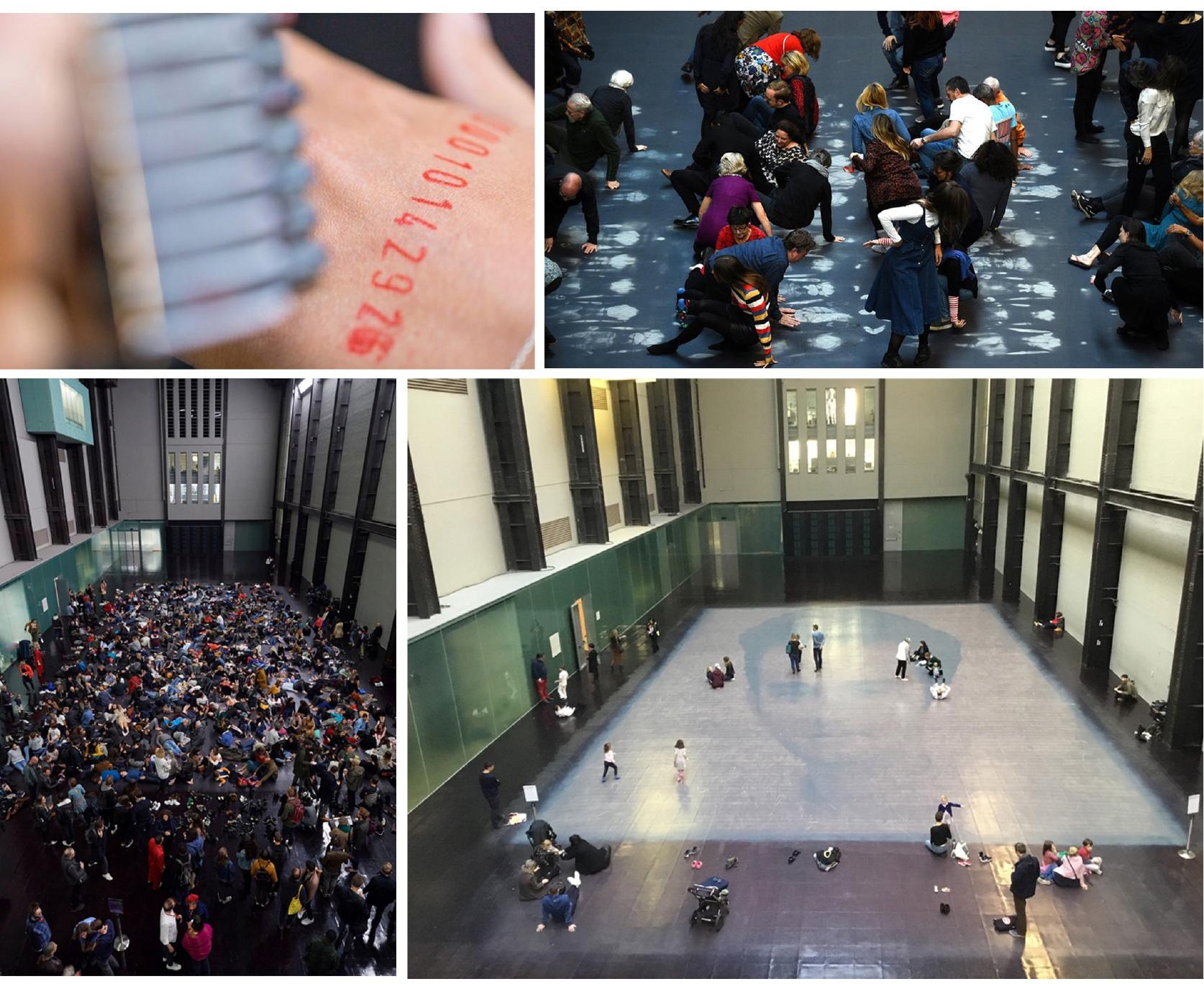

Fig. 2.15. Tania Bruguera, 10.142.926, Instalación, (2019) 
Continuando con la gráfica corporal expandida en el espacio de la instalación, contamos con la obra de la artista polaca Zuzanna Dyrda, con quien tenemos una gran amistad y un sinnúmero de afinidades que nos vinculan a un territorio común: la piel. Tanto en el marco de su trabajo como en el nuestro, el cuerpo/piel hace de matriz y soporte en la acción performática que deja la huella como evidencia. En la obra Brudas (Guarro) (2016-2017) Dyrda graba en relieve todas las superficies de un sauna de madera, que luego entinta con pigmento negro para que estas marcas entren en contacto directo con los cuerpos desnudos que ingresan dentro de este espacio. El resultado de esta acción se expone al público a manera de un conjunto de obras compuestas por la videoinstalación y la respectiva documentación fotográfica del proceso de impresión, en la que se traslada a la sala de la galería el objeto matriz (sauna intervenida) (Fig. 2.16). De esta manera la artista conjuga la fórmula básica del grabado en los que dispone de la matriz, la tinta, la presión y la superficie, de una manera novedosa y particular, según apunta Richard Noyce (2017) en la introducción del catálogo Interference into the object. Transóressive Print. Arworks of Zuzanna Dyrda ${ }^{7}$ :

Ofrece una especie de espejo en el que podemos vernos reflejados, no tanto en nuestra desnudez en las formas expresadas por los modelos en la obra, sino como seres humanos considerando lo que eso puede y debe significar. Nos enfrentamos a una piel ensuciada por las marcas de tinta y la repetición de fragmentos de la palabra Guarro, lejos de la fría pureza y el idealismo del desnudo clásico. (p.7)

Dyrda juega con el sarcasmo al enfrentar el papel que desempeña el ritual social de la sauna (limpieza y purificación corporal) y lo que acontece dentro de él en su performance gráfico. En este contexto, las improntas

\footnotetext{
${ }^{7}$ El texto original está escrito y publicado en inglés. Para efectos de esta tesis, Priscilla Romero hizo la traducción al castellano de la cita:

It offers is sort of mirror in which we can see ourselves reflected, not so much in our nakedness in the ways expressed by the models in the work, but as human beings considering just what that can, and should, mean. We are faced with skin made dirty by ink marks and repetition of fragments of the word Slob, far away from the cold purity and idealism of the classical nude. (Richard Noyce, 2017, p.7)
} 
juegan una doble función, por un lado la tinta viste, uniforma y ensucia los cuerpos desnudos, y por otra parte los etiqueta con palabras ofensivas que agreden simbólicamente su corporeidad. Una potente metáfora visual que nos habla de la piel como la superficie que encarna nuestra imagen corporal y cómo esta se somete constantemente a juicios de valor en los ritos de interacción social, en los que se codifica la percepción y construcción de nuestra identidad individual y su copertenencia al cuerpo comunitario.

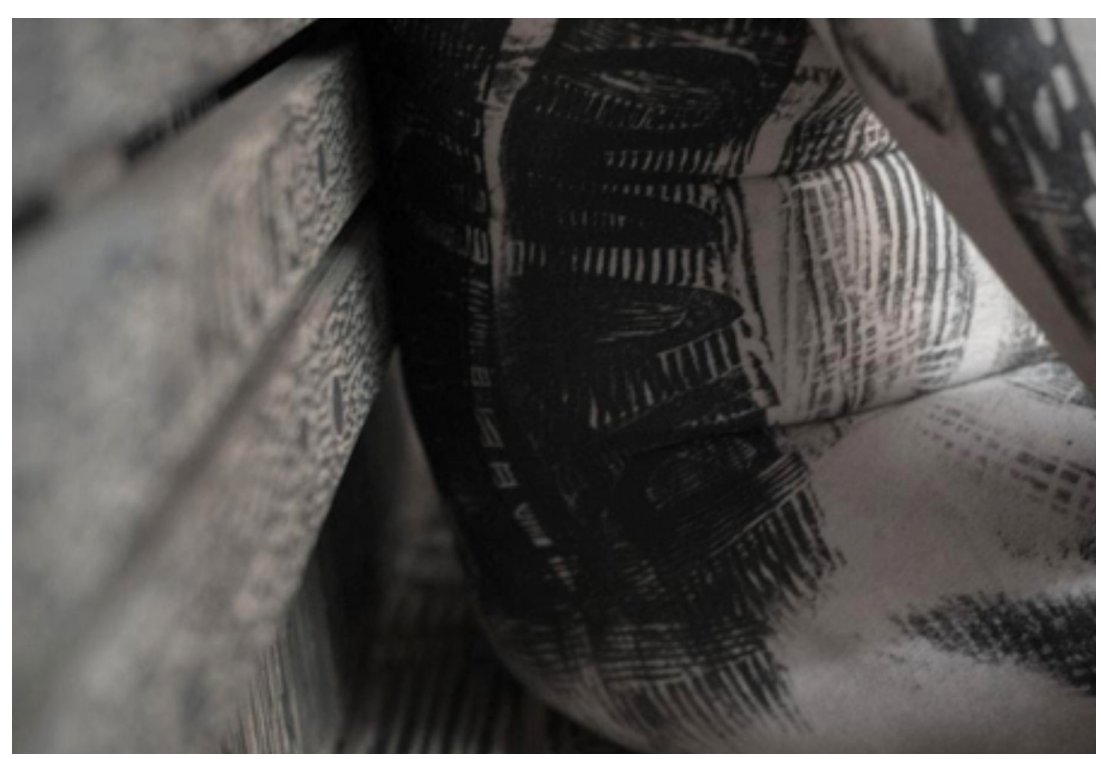

Fig. 2.16. Zuzanna Dyrda, Brudas, Impresión xilográfica sobre piel y videoinstalación, (2017)

En uno de sus más recientes trabajos titulado Kindred (Parientes) (2019), la artista polaca plantea una acción lúdica en la que los voluntarios imprimen sus manos entintadas sobre el rostro. En ese caso, el cuerpo propio, es la matriz que se desdobla fenomenológicamente para servir también de soporte sobre el cual se registra su huella (Fig.2.17). Gracias a la impresión lenticular, la imagen resultante registra el momento en que se imprime la huella interactivamente para que el espectador descubra esta otra imagen al moverse de un lado al otro. En sintonía con Dyrda, el tacto es más que un sentido; tener tacto implica establecer una relación empática para percibir la realidad. De modo que a lo largo 
de nuestra existencia vamos acumulando metafóricamente las huellas de las personas y situaciones con las que nos encontramos en el camino, esos otros con quienes no tenemos un ligamen sanguíneo pero que por circunstancias de la vida consideramos como parientes. La piel hace de archivo gráfico de nuestra existencia: documenta, registra y transfiere la memoria de nuestro ser-en-el-mundo, una experiencia que se vuelve latente en su trabajo, del mismo modo que en la presente investigación.
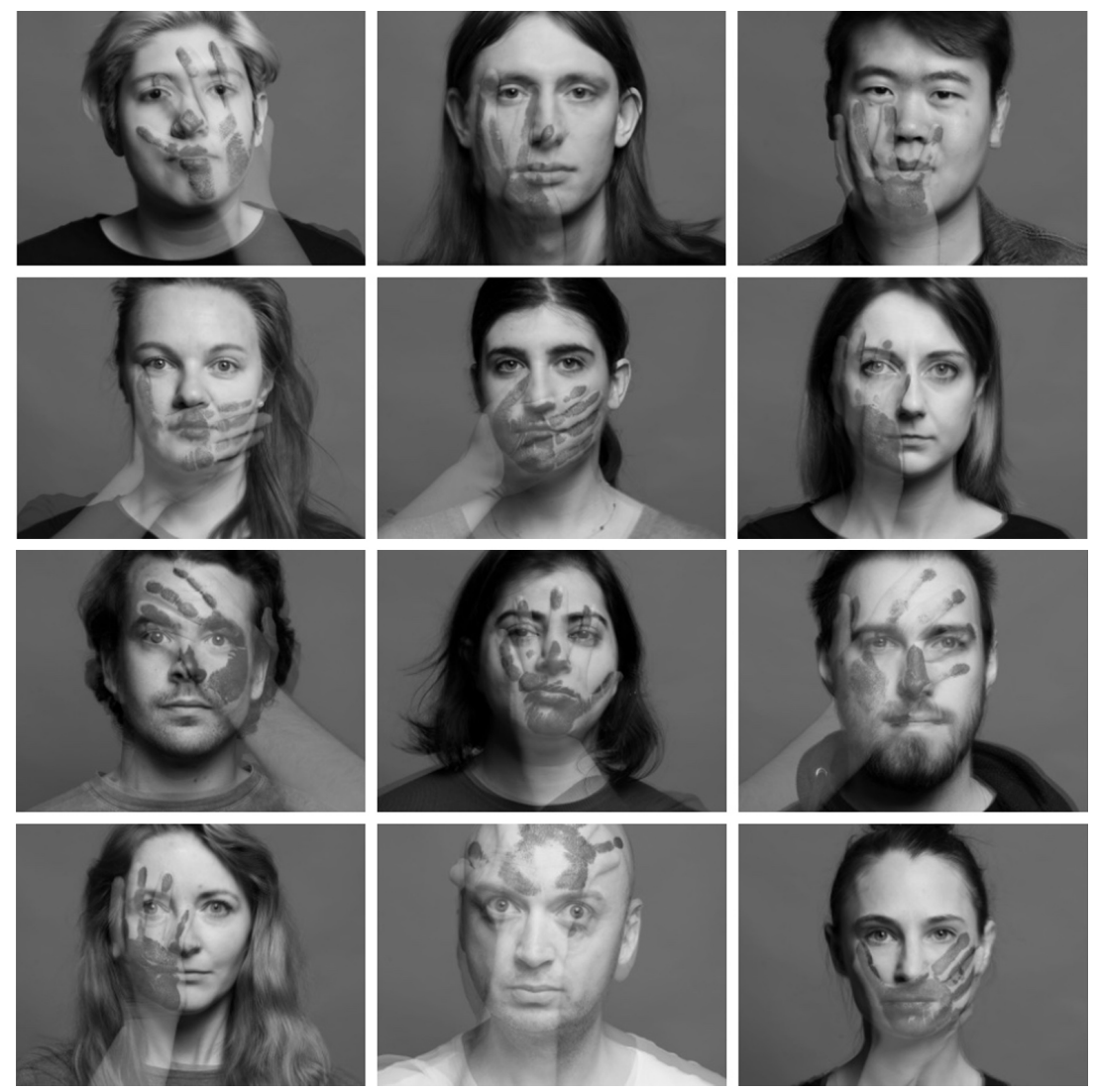

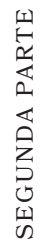

Fig. 2.17. Zuzanna Dyrda, Kindred (Parientes), Impresión corporal e impresión lenticular. (2019) 
Para terminar este apartado nos gustaría referirnos a la idea del grabado como documentación de una realidad ya existente, en otras palabras, a la apropiación de una superficie receptora y emisora de huellas que ejerza de matriz, como es el caso de la piel. Nuestra labor ha sido transferir y reimprimir pruebas de estado del cuerpo a través de la transmutación de la matriz primigenia en huella latexgráfica. Precisamente la transmutación de la huella corporal es lo que nos vincula con la serie titulada Phone Etchinǵs (Aguafuertes de Móviles) (2015) de la artista alemana Andrea Büttner (Fig. 2.18). Estas imágenes fueron realizadas a partir de los residuos grasos que dejan las huellas dactilares sobre la pantalla de su móvil, las cuales transfirió fotográficamente a una matriz calcográfica de gran formato. El gesto abstracto que deja el contacto corporal queda grabado en aguafuerte sobre el metal y contrasta con la pulcra apariencia estética de las pantallas digitales de donde se extrajeron las muestras. Con esta acción se establece un discurso visual entorno a la relación entre el ser humano, los dispositivos móviles y el rol de la piel como interfaz de esta experiencia vivencial, así como el diálogo entre las técnicas tradicionales del grabado y los nuevos medios, al tender un puente entre la matriz digital e intangible con la matriz analógica. A razón de lo anterior, Pelzer-Montada (2018) hace la siguiente reflexión ${ }^{8}$ :

La transposición a través del campo de orientación, escala, medio y color, de lo horizontal a lo vertical, de lo minúsculo a lo monumental, de la pantalla fresca y lisa a la cualidad táctil del grabado, de las texturas aceitosas sin color a los tonos aterciopelados e irreales de los primarios y blanco y negro. Le da un matiz distinto de materialidad y presencia a lo efímero y lo fugaz. Las obras parecen funcionar metonímicamente para el cuerpo en sí, tanto en su alteridad y diferencia abstraída, como en su insistente carnosidad material. (p.519)

En resumen, la huella, producto del contacto fugaz del cuerpo, queda materialmente registrada para preservar su memoria. Por su parte, Büttner realiza una captura de pantalla en la que en vez de fijar temporalmente la

\footnotetext{
${ }^{8}$ Este texto está publicado tanto en castellano como en inglés.
} 
imagen que proyecta esta superficie, transmuta la huella-casiinvisible-que dejan los dedos sobre ella. Es decir, recoge las evidencias que todo cuerpo deja tras sí, de manera paradójicamente intacta y con la meticulosidad de un estudio forense. Por nuestra parte, transmutamos la huella directa de la piel; por lo que las matrices latexgráficas son producto del contacto entre el cuerpo y el material receptor. De una u otra manera, el grupo de imágenes que hemos revisado brevemente en este apartado surgen de la necesidad de documentar el contacto en todas sus dimensiones: ya sea el encuentro que sucede físicamente entre dos cuerpos, o el que a diario acontece al confrontar las realidades anacrónicas que existen entre la ausencia y la presencia, la memoria y el olvido o el pasado y el presente.

Lo cierto es que la remanencia de la impresión persiste en todos los referentes citados, donde el cuerpo/piel ejerce una función reversible, dado que se comporta como matriz o soporte, e inclusive ambos. Proyectos en los que más allá de la huella en sí, lo que interesa es el proceso a través del cual se registra. La tinta es la sustancia a través de la cual se transfiere tradicionalmente la imagen de la matriz al soporte, pero en el marco de los trabajos examinados adquiere múltiples posibilidades que amplían su concepción técnica y poética. Por ejemplo, Klein utiliza su reconocido pigmento azul (YKB) como su marca de identidad artística, Mendieta recurre a la alquimia de las materias para realzar las siluetas impresas en un soporte efímero, Galindo impregna sus pies con sangre humana, Calvo estimula la melanina de su piel para alterar la pigmentación natural, Bruguera recurre al calor corporal para que la superficie termosensible registre la impronta; y tanto Dyrda como Büttner utilizan, la tinta viscosa del grabado xilográfico y calcográfico para enfatizar esa carnalidad de la huella y contrastar su gestualidad con el registro digital.

Fig. 2.18. Andrea Büttner, Phone Etchinǵs (Aguafuertes de Móviles), Aguafuerte, (Detalle) (2015) 
Cada huella es el registro del contacto, acción en la que el cuerpo se desdobla dejando tras de sí una impronta, una prueba de estado que atestigua el aquí y el ahora que no volverá jamás, porque el tiempo no se detiene para nadie y sus marcas se van grabando en la piel. Tal y como describimos en el Capítulo 1. Latexǵrafía, sentido y práctica, la huella de la piel se transmuta en el material con el que entra en contacto directo, por esta razón, nuestras huellas pueden ser translúcidas, negras, doradas o blancas, porque se mimetizan con el soporte que las recibe. Con la reproducción de la matriz latexgráfica perpetuamos la memoria y expandimos su huella en diferentes contextos, en los que la imagen pervive a su matriz primigenia (el cuerpo). Desde la reflexión fenomenológica, podríamos decir que somos la huella del mundo, nuestro cuerpo se encarna en él dejando tras de sí una prueba de su momentánea presencia. Entonces, ¿qué significa dejar huella? Habitualmente supone ser recordado por lo bueno y no por lo malo, por la huella y no por la herida o cicatriz. Sin embargo, tal y como hemos expuesto, desde nuestro enfoque creemos que la memoria de la piel lo abarca todo en un documento gráfico, que lejos de ser juzgado es expuesto para revalorar su relato resiliente.

\subsubsection{FRAGMENTOS DE MEMORIA}

La repetición y el fragmento son dos recursos primordiales en nuestro proceso creativo: el primero refuerza la dimensión ritual del ejercicio artístico, experiencia mediante la cual reproducimos la acción de dejar huella y la perpetuación de la memoria de la matriz, y el segundo viene a subvertir la imagen corporal de los ideales dominantes que la constriñen a una unidad indivisible y cerrada; acercándonos al cuerpo en tanto que yacimiento arqueológico de vestigios supervivientes. En el plano formal, la fragmentación ocurre en el proceso mismo en el que registramos la huella corporal mediante la latexgrafía, ya que solamente transferimos el trozo de piel que nos interesa, para que este pase a ser parte del conjunto de piezas del rompecabezas. El poder mental de lo incompleto y fragmentario radica en su capacidad de evocación: "Quien no puede recordar apenas puede imaginar, pues la memoria es el terreno donde 
crece la imaginación. La memoria es también el terreno de la identidad: somos lo que recordamos" (Pallasmaa, 2018, p.16). Gracias a la dimensión lúdica de la fragmentación podemos activar un juego memorístico en el que el espectador intenta reconstruir libremente la imagen inacabada del cuerpo, mediante los fragmentos de las huellas que le proporcionamos.

Pero el poder evocador de lo fragmentario no acaba aquí, sino que nos remonta a una imagen primigenia del cuerpo propio y del otro; tal y como apuntan las teorías psicoanalistas de Lacan (1990) alrededor del conocido Estadio del espejo, donde se plantea que la percepción mental del cuerpo, como unidad completa, no se da hasta que nos autoreconocemos en la imagen refleja por vez primera, durante una etapa temprana de la niñez. Sin embargo, aún siendo adultos, la totalidad del cuerpo no es una percepción que logremos desde nuestros sentidos, ya que si dejamos de lado cualquier instrumento técnico para reproducir imágenes (como puede ser los espejos, cámaras o móviles), caeremos en cuenta que cotidianamente experimentamos nuestra corporalidad a través de fragmentos que podemos sentir con las manos y enfocar con la vista; un recorrido háptico que constantemente realizamos en nuestra práctica al seleccionar puntualmente el área que deseamos registrar.

A razón de lo anterior, en este apartado revisaremos una serie de obras que utilizan el recurso del fragmento para conjugar la memoria de la huella y el contacto corporal en la gráfica contemporánea. Iniciamos este recorrido con la obra titulada Epiermic Scapes (Paisajes Epidérmicos) (1977-82) de Vera Chaves Barcellos, artista brasileña que desde los años 60 ha venido aportando a las poéticas en torno al cuerpo, su registro múltiple y fragmentado (Fig. 2.19 y 2.20). Este conjunto de imágenes se compone de fotografías en gran formato que reproducen las huellas de la piel de la artista y de otras personas. Para obtener estas improntas, la artista previamente entinta la piel e imprime la huella sobre papel vegetal, ejerciendo presión directa en el contacto y frotando la superficie para transferir las texturas. A diferencia de nuestro trabajo, en el que se mantiene la escala real de la huella, en los Paisajes Epidérmicos se aumentan monumentalmente las imágenes macro de la piel para 
disponerlas sobre el suelo, tal como si fueran grandes mapas o vistas aéreas de planos terrestres que dislocan el vínculo entre la impronta y el cuerpo como unidad referencial, así como la llamada escala humana desde la cual dimensionamos el mundo y sus proporciones.

Esta relación paradójica entre un detalle hiperrealista del cuerpo y la abstracción que evoca, es un juego de acertijos al que también nuestras imágenes invitan a participar, dado que poco nos detenemos en apreciar la topografía del ombligo o las texturas de los bellos púbicos. Esta ambigüedad despierta en el público la curiosidad de saber de dónde provienen las improntas. De repente, esta obra nos confronta con una percepción atípica de la piel, y por ende del cuerpo en tanto superficie extensa y diversa.

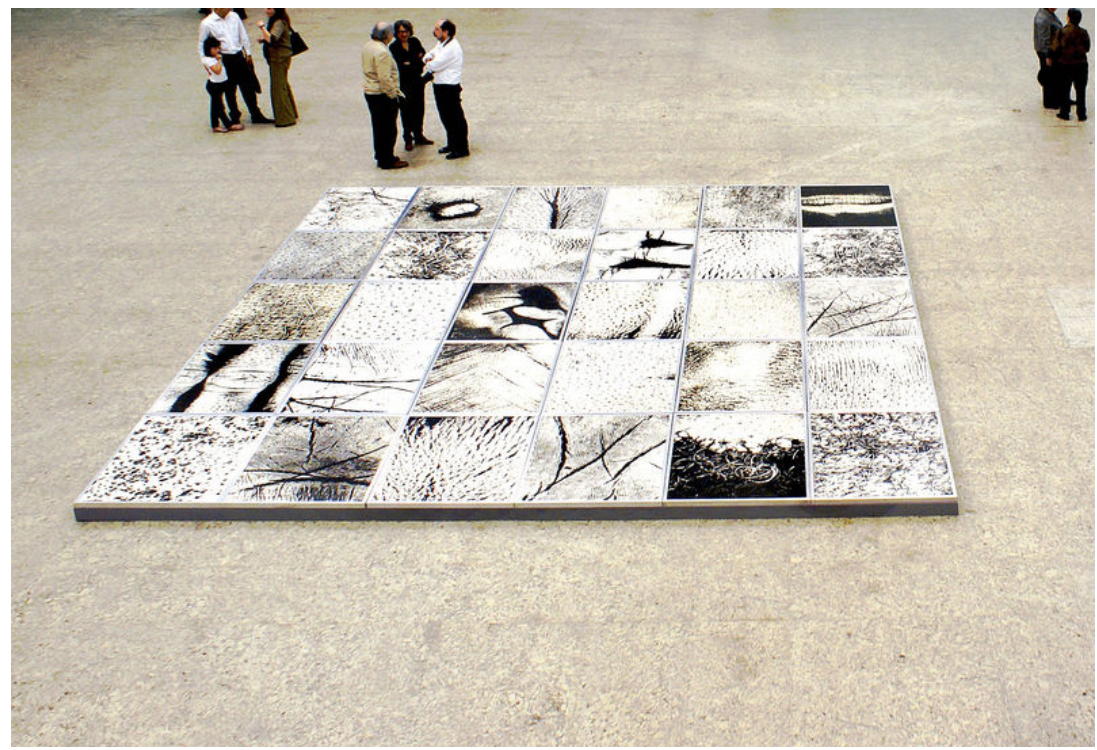

Fig. 2.19. Vera Chaves Barcellos, Epiermic Scapes

(Paisajes Epidérmicos), Fotografía, (1977-82) 

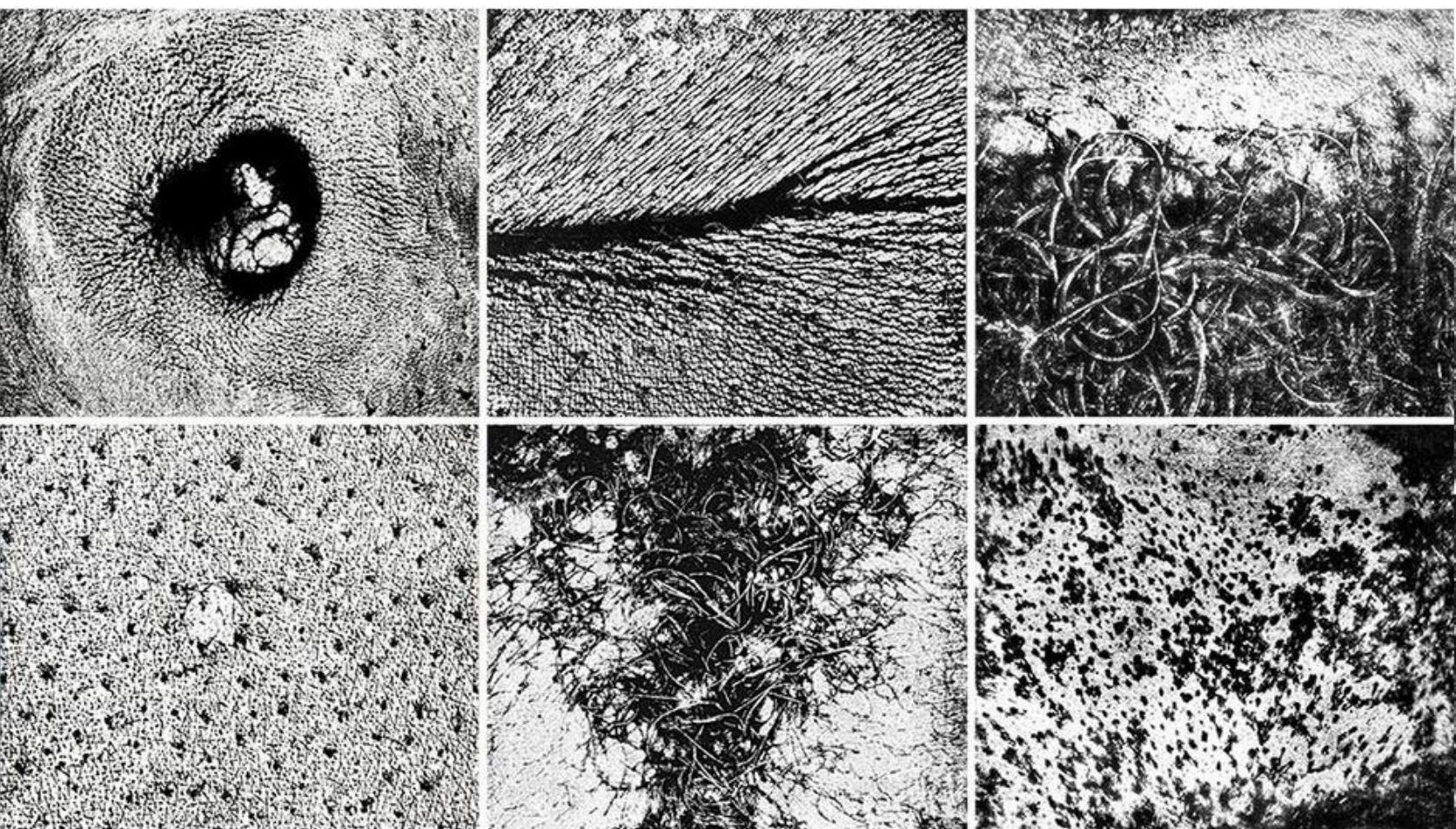

Fig. 2.20. Vera Chaves Barcellos, Epiermic Scapes

(Paisajes Epidérmicos). (Detalle) 
Por su parte, la costarricense Karla Solano realizó en el año 2010 una exposición retrospectiva de su trabajo titulada Mudar de Piel, en el Museo de Arte y Diseño Contemporáneo de Costa Rica (MADC). Del conjunto de obras de esta muestra nos gustaría destacar el Jardín Corporal (2007), en la que Solano planteó un conjunto fotográfico extraído de fotogramas de un video que la artista realiza a ras de piel y que expone a manera de friso que recorre la sala (Figs. 2.21 y 2.22). Los recursos de fragmentación, montaje y repetición son tan comunes en su proceso creativo como en el nuestro, para aludir al estado de lo incompleto del cuerpo y consecuentemente a su recomposición. En este juego formal también se aborda la piel como superficie territorial extensa, en la que existe una tensión entre lo macro-micro e interno-externo de una corporalidad reducida a múltiples componentes metonímicos. Al igual que en la obra de Chaves Barcellos, Solano amplía sus imágenes para dislocar la referencia a un cuerpo específico e invitar al espectador a navegar por los recovecos de la piel, capturados directamente con el objetivo de su cámara. Con respecto a esta aproximación artística, la comisaria del MADC, Chavarría Zamora (2010) apunta lo siguiente:

Ella nos lleva por un recorrido corporal, en donde desaparece la propia identidad. Ese cuerpo no es solo uno, las marcas y cicatrices pueden reconocerse en los otros. Hallar presencia de un ciclo vital que va marcando el paso de los años, cada uno como una particularidad, un reloj. La piel se ve marcada por el día a día, va cambiando, se van dejando huellas, pedazos de uno mismo, fracciones que componen parte de una singularidad. (p.7)

Como hemos apuntado, el corpus de obra propia de esta investigación posee grandes nexos con Jardín Corporal, ya ambas plantean una imagen poética en la que apreciamos la belleza de lo inconmensurable: ese punto de encuentro entre lo abyecto y lo inaprehensible de nuestra corporalidad. Cada fragmento de Jardín Corporal representa un punto de vista indagatorio en el que la artista, al igual que nosotros, penetra la intimidad de la geografía corporal, con cierto sentido lúdico y hasta inocente, para buscar -con lupa- sitios que aún no han sido descubiertos y trasferir a la imagen fotográfica estos estimulantes territorios, como cavernas pélvicas, bosques de bellos o llanuras de poros. Un cúmulo paisajístico que nos invita a deambular por estos micromundos de la piel. 


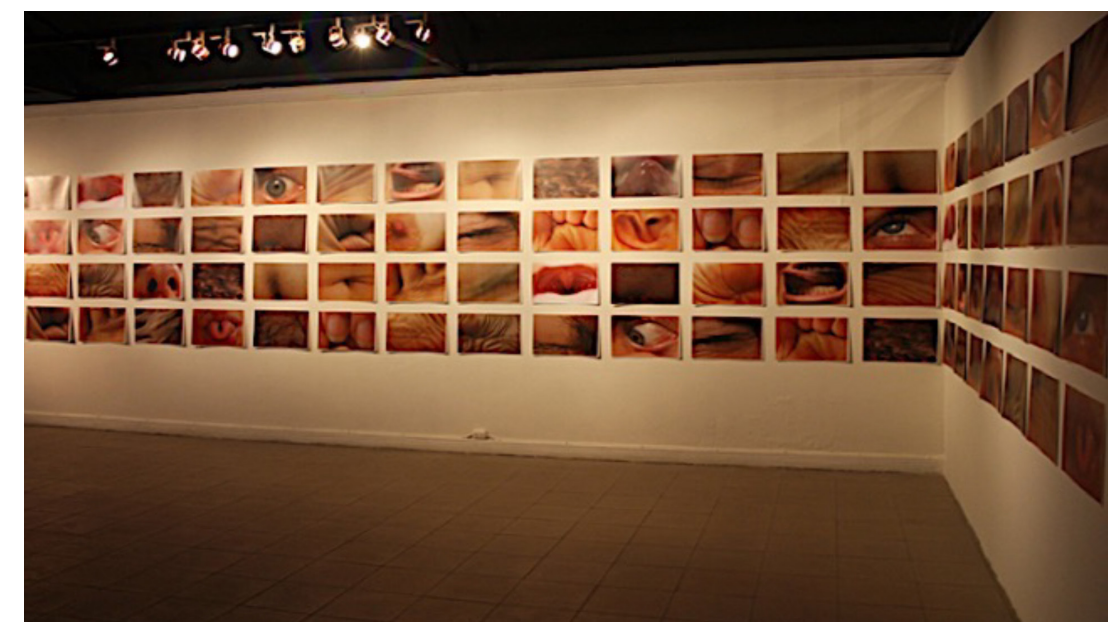

Fig. 2.21. Karla Solano, Jardín Corporal,

Fotografía, instalación, 2007.
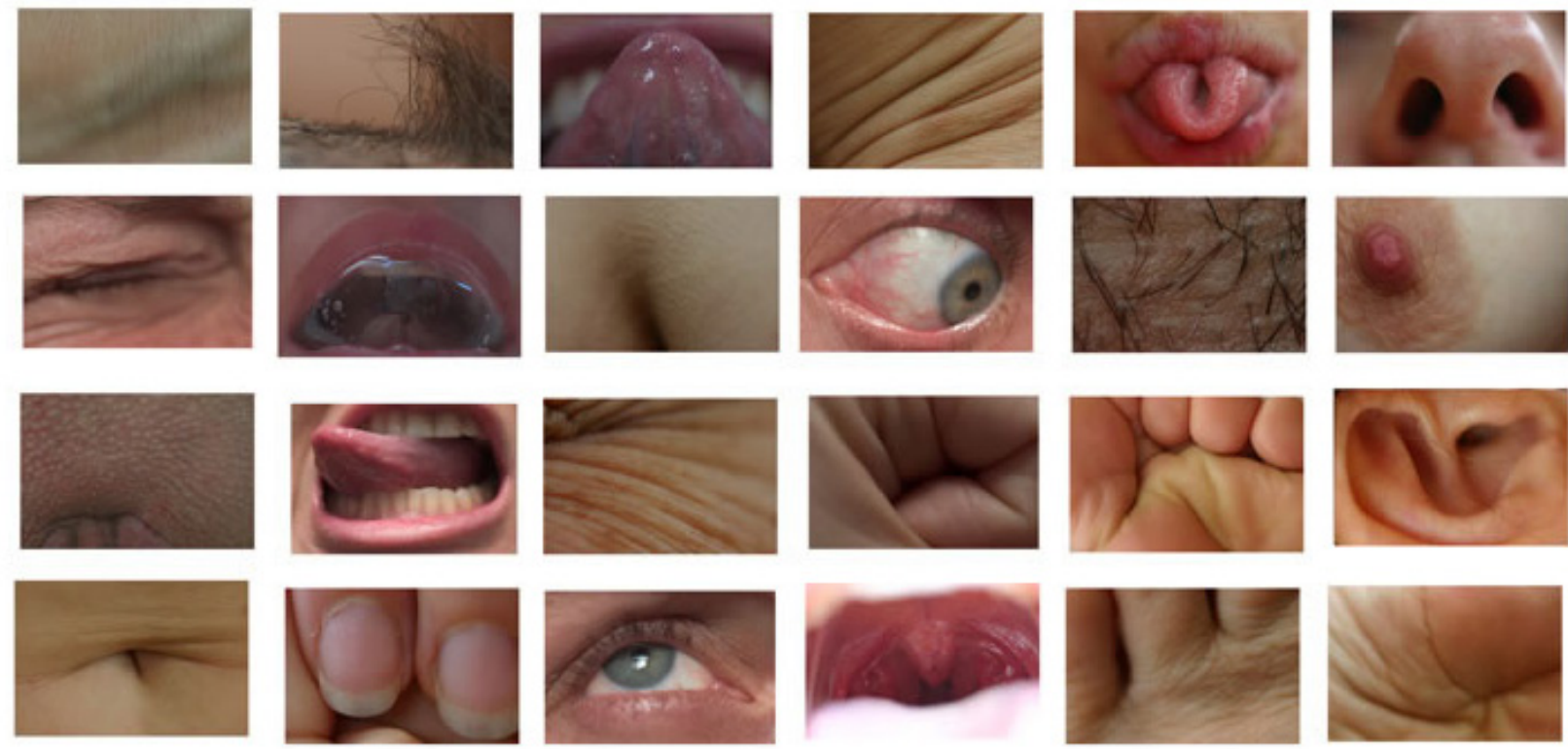

Fig. 2.22. Karla Solano, Jardín Corporal. (Detalle) 
En las imágenes que revisaremos a continuación veremos varios ejemplos en los que el fragmento cutáneo cobra volumetría. El primer conjunto pertenece a Kiki Smith, artista estadunidense que históricamente ha tenido un peso muy importante en nuestro trabajo. En la obra Sin título conocida como Skins (Pieles) (1992), Smith realiza improntas de fragmentos corporales en escayola que luego funde en aluminio (Fig. 2.23). En este díptico de gran escala recompone las huellas de todas las partes del cuerpo en un espacio sin orden jerárquico, dejando que sean las texturas cóncavas y convexas de la piel las que den movimiento a esta retícula modular. La impronta de la piel nos remite a lo orgánico y fluido del tejido, en contraste con la escayola y el aluminio que nos demarcan una realidad constante. Este encuentro discordante es una intención

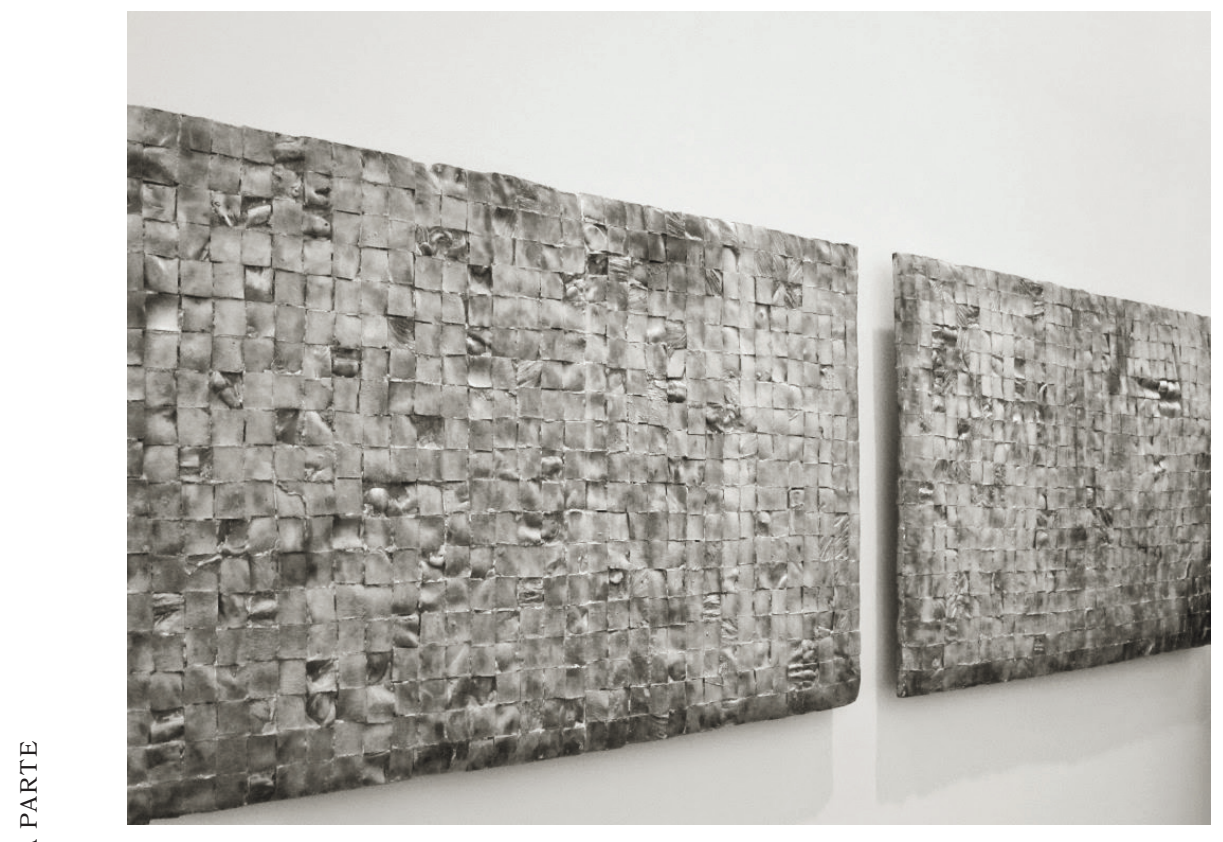

Fig. 2.23. Kiki Smith, Sin título (Skins) Pieles), Moldes fundidos en aluminio, (1992) 
consciente de la artista para evocar las pulsaciones de lo humano, esa fuerza vital que nos mantiene vivos, en suma: la armonía entre la razón y la emoción. Lo anterior se ve en una gran parte del corpus de obra artística de nuestra investigación, la cual está organizada mediante el concepto de módulo, retícula y repetición. El módulo puede acoplarse al espacio y así extenderse sin que tenga un límite aparente, y con esta estrategia también se abren los limites físicos y simbólicos de la representación imaginaria del cuerpo y sus contingencias.

Nuestro próximo referente es la obra titulada Cutáneo (2001), del artista español Javier Velasco, la cual consiste en una performance registrado fotográficamente en la que se aplica látex directo a su piel para extraer pequeñas muestras/fragmentos que luego proyecta en diapositivas para visualizar ampliamente su detalle (Fig. 2.24). Esta exploración -casi forense- del cuerpo propio tiene una gran similitud con nuestro trabajo, ya que el sujeto se ve a sí mismo en búsqueda de sus pliegues y rincones; esas partes significantes que nos muestran las riquezas de un universo de pequeñas partes que llevamos a cuestas y que dialoga metonímicamente con el todo. Esta práctica, es una acción que realizamos continuamente en nuestro estudio, tanto a la hora de extraer el molde de látex del cuerpo como de su transferencia en otros soportes. El método del visor aísla el fragmento que deseamos de ese territorio agreste y convulso al que llamamos cuerpo y que hemos dividido en partes más pequeñas, planos, mapas y zonas de interés para perdernos en su infinidad de tramas y texturas. La complejidad del cuerpo nos abruma y sobrepasa, en cambio, los fragmentamos nos ofrecen pequeñas certezas, aunque incompletas y ambiguas. 

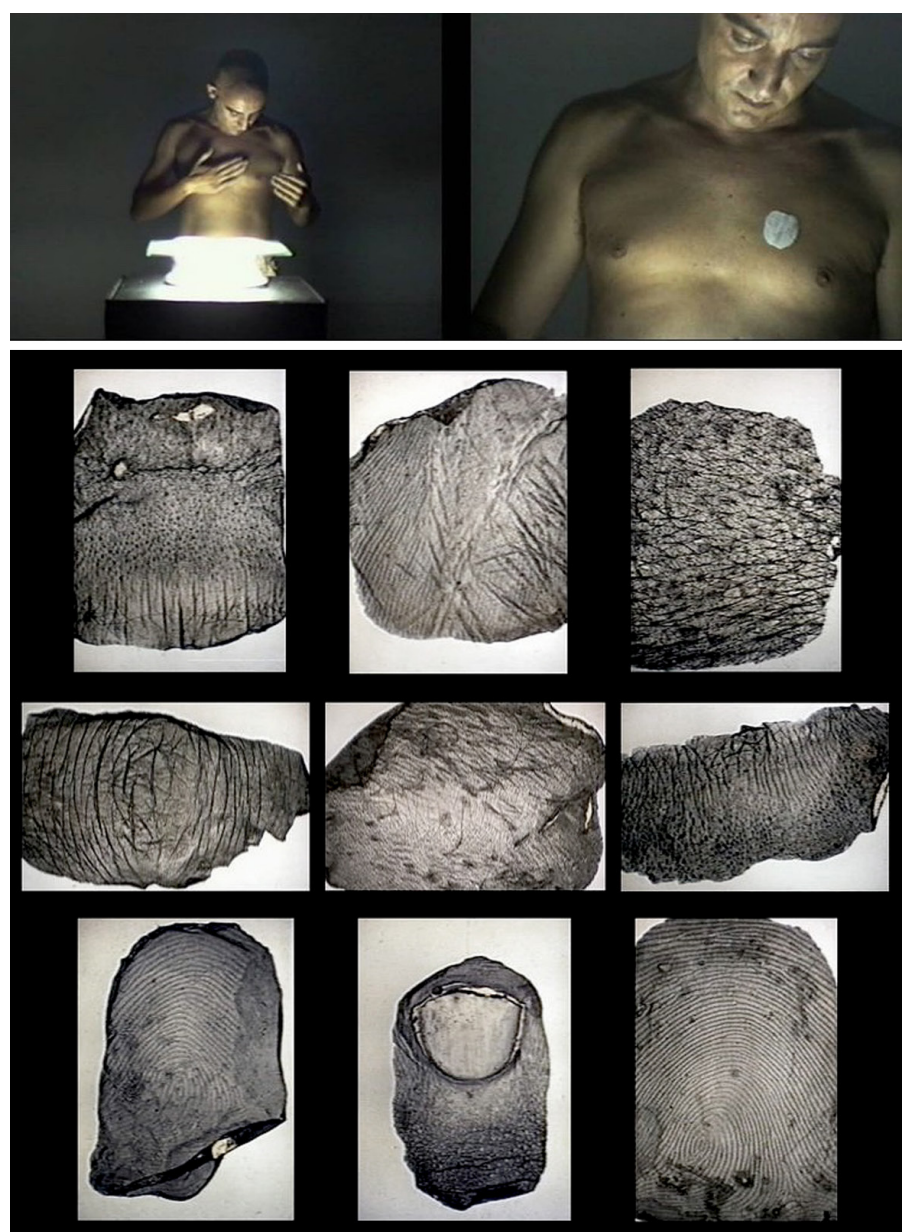

Fig. 2.24. Javier Velasco, Cutáneo, Foto performance-látex sobre piel, (2001)

Siguiendo con la exploración del cuerpo, el hallazgo del fragmento y el registro de su huella para perpetuar la memoria, la artista polaca Alina Szapocznikow nos ofrece una serie de obras tituladas Herbarium (1972) en las que hace moldes de su cuerpo y el de su hijo a través de la aplicación de látex (Fig. 2.25). En este proceso la artista desdobla el cuerpo al expandir su volumen en moldes que asemejan una segunda 
piel desgarrada. Szapocznikow encarna en este corpus de trabajos los horrores y disyuntivas en torno a su experiencia traumática en los campos de concentración y exterminio nazi durante el Holocausto. Fragmentos de pies, rostro y pechos, son la evidencia de un cuerpo que estuvo presente. Un encuentro plástico entre las características físicas de las superficies que estuvieron en contacto directo: la piel y el látex. Sin duda un resultado que vincula esta imagen con la práctica cotidiana de la latexgrafía y la expansión topográfica de la epidermis que en ella realizamos.

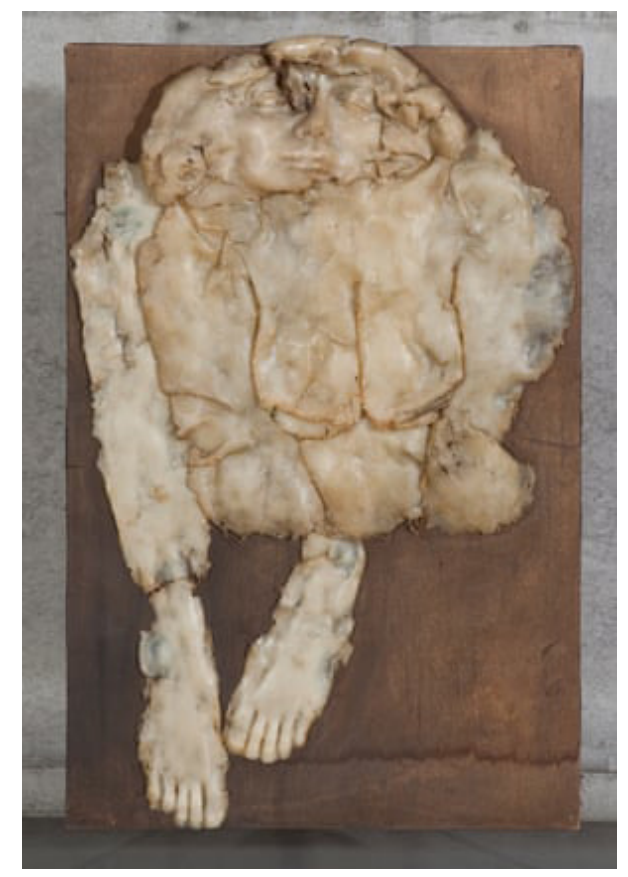

Fig. 2.25. Alina Szapocznikow, Herbarium/ autorretrato, Moldes de látex y ensamble de madera con poliuretano, (1972) 
En Aliento (1995) (Fig.2.26) y La Mirada del Cíclope (2005) (Fig. 2.27) del reconocido artista colombiano Oscar Muñoz; ambas con una década de por medio, pero con una repercusión muy fuerte en nuestro trabajo. Muñoz se ha caracterizado por reflexionar alrededor de la documentación gráfica de la memoria a partir de la poética del material, la interacción con el público y el espacio. La primera obra consiste en una serie de platos metálicos puestos en la pared, en cuya superficie reflectante las personas se pueden mirar de cerca hasta que la distancia entre su cuerpo y esta superficie abre la imagen oculta, gracias al vapor que emana del aliento. Primeramente, el metal se empaña y enseguida devela un rostro anónimo que ha sido grabado en la superficie grasa sensible al cambio de temperatura y humedad. En esta acción aparece ese otro que te mira interpelando por su identidad desconocida, la misma que poco a poco desaparece en la medida en que el espectador se retira del objeto.

Una obra que amerita de la interacción de la audiencia, activando su respuesta corporal en un juego lúdico con un trasfondo discursivo y político, dado que los retratos ocultos pertenecen a personas anónimas desaparecidas en el contexto de los conflictos armados de Colombia. Por su parte, en la segunda obra La Mirada del Cíclope corresponde a una serie fotográfica y una videoinstalación en las que Muñoz juega con su máscara negativa de escayola, moviéndola lentamente para que la ilusión óptica tenga lugar. Por momentos no sabemos si es cóncava o convexa, negativa o positiva, hasta que caemos en cuenta que es tan sólo es una máscara. Sí, una máscara con un potente contenido que nos remonta a la figura del imago romana y sus matrices funerarias, en las que se inmortalizó el rostro de la persona fallecida para preservar su memoria. Este rasgo precede inclusive al propio concepto del retrato como representación, puesto que se buscaba la máxima semejanza, porque de alguna manera se le otorgaba a la persona una identidad civil reconocible, algo así como lo que hoy sería un registro de defunción que archiva el orden simbólico y genealógico, en palabras de Didi-Huberman (2015): "La imagen no es aquí más que un soporte ritual que compete al derecho privado" (p.111) 

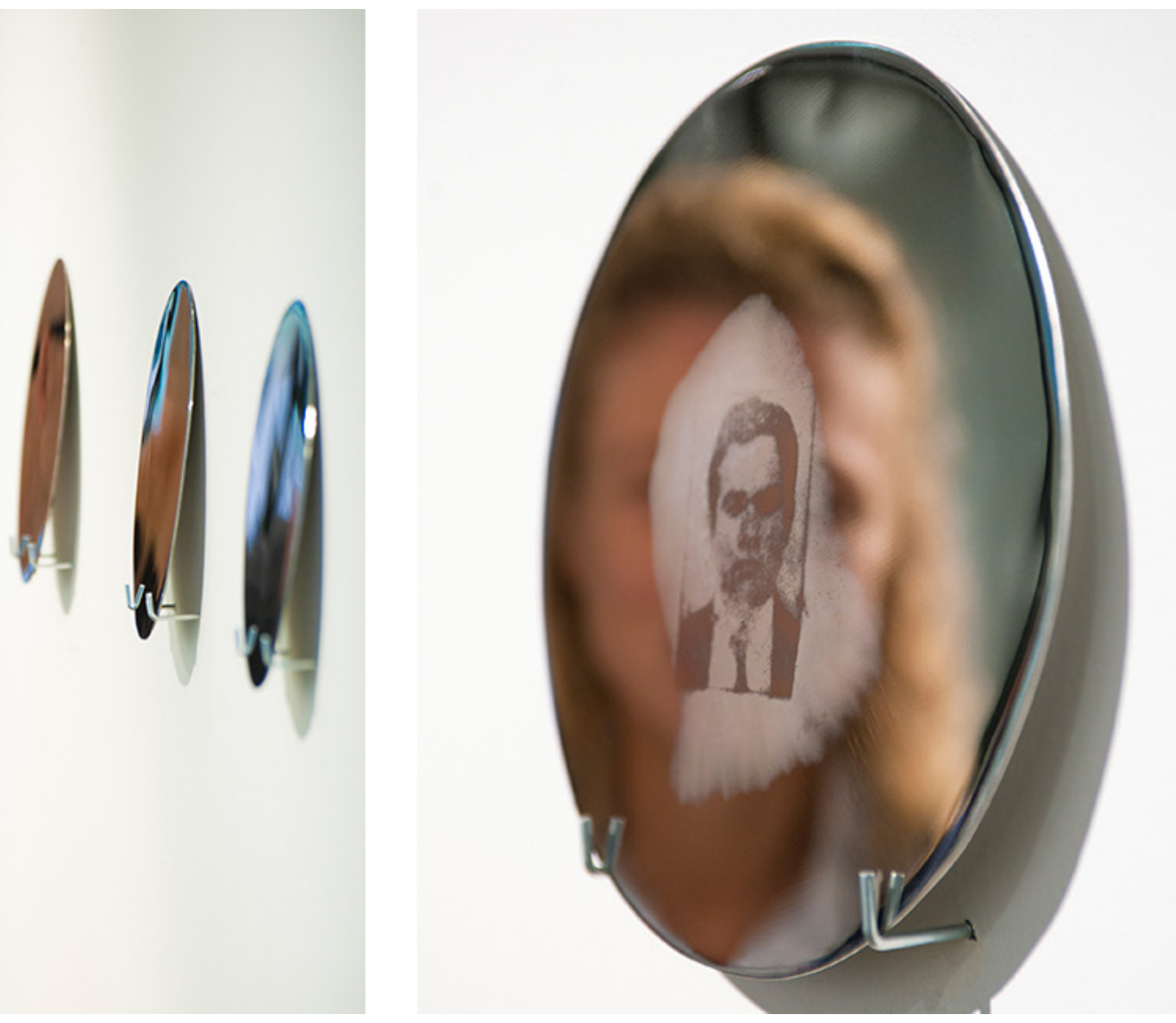

Fig. 2.26. Oscar Muñoz, Aliento, Doce discos metálicos con serigrafía impresa sobre película grasa, (1995). 


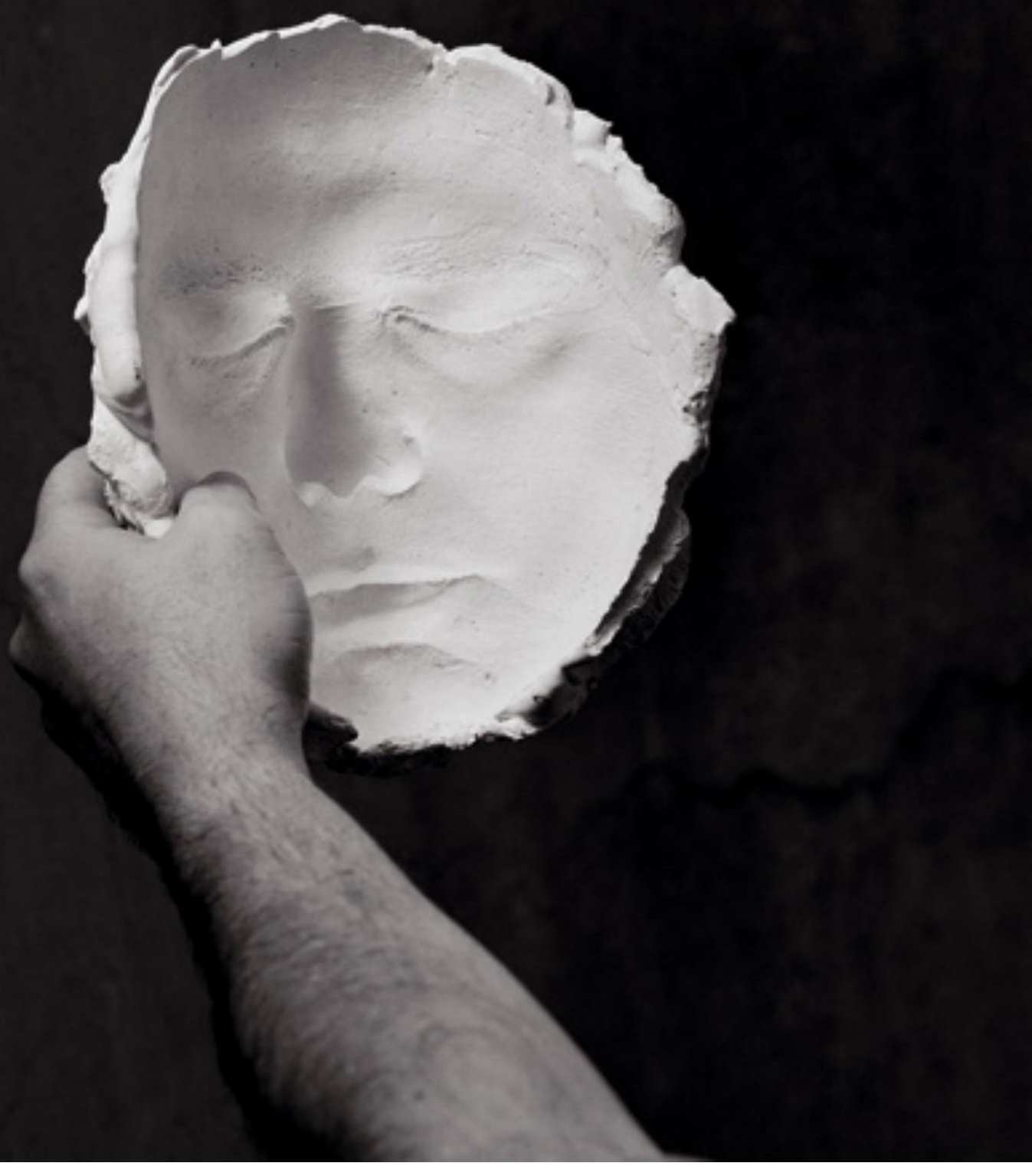

Fig. 2.27. Oscar Muñoz, La Mirada del Cíclope,

Máscara de escayola y videoinstalación, (2005). 
Por último, y no menos importante, se encuentra la obra $A$ flor de piel (2011-2012) (Figs.2.28 y 2.29) a cargo de Doris Salcedo, para quien nos sobran los calificativos para poder sintetizar su trabajo en pocas palabras; sin embargo y conociendo su trayectoria, que la posiciona como una de las baluartes contemporáneas más reconocidas mundialmente en el arte de la memoria, es preciso destacar que en este proyecto en particular, la artista construye, lo que ella misma ha expresado como un manto fúnebre, a partir de rojos pétalos de rosa, cuyas nervaduras de inmediato nos remiten a la piel en carne viva. Cada pétalo es un fragmento modular, que minuciosamente ha sido tejido con costuras quirúrgicas hasta formar esta tela, o segunda piel, para rememorar a las víctimas ausentes y anónimas de la violencia infringida a las mujeres en el contexto del conflicto armado colombiano.

Salcedo, nos muestra, -una vez más- cómo a través de la elección de la materia y del proceso en que se lleva a cabo la obra, se potencializa un mensaje que literalmente nos deja los sentimientos a flor de piel. Esta instalación remite a lo frágil y vulnerable de la condición humana, al duelo y la muerte, pero también al fugaz paso del tiempo que poco a poco hace que cada pétalo se seque y oxide, tal cual lo haría un río de sangre sobre el suelo de la sala, reduciéndose a residuos y pequeños fragmentos de lo que algún día floreció. Es esta dialéctica -inseparable entre los distintos niveles de contenido que emanan del proceso creativo, incluyendo el propio título de la obra, lo que nos une a su discurso y práctica, además, claro está, de la tremenda admiración y respeto por infiltrar desde el arte su posicionamiento político y social. Cada pétalo, representa metonímicamente, a una persona, sin que se evidencie la identidad propia, todas juntas son la piel del drama humano, llevado al extremo de la empatía estética sin perder de vista la coherencia de la forma y el concepto. 
Fragmentos de memoria corporal, trozos del tiempo que se relacionan anacrónicamente en nuestro universo ficcional para representar los avatares más íntimos y los dramas sociales. Pequeños indicios que nos brindan pistas para re-imaginar lo acontecido, para reescribir el pasado en tiempo presente; tomando como referencia los relatos grabados en el archivo gráfico de nuestra piel. El giro de la memoria ha impregnado gran parte de la cultura visual desde finales del siglo pasado hasta la fecha, abriendo un área de experimentación artística en la que, como hemos visto, se utilizan estrategias multidisciplinares para interrogar la historia oficial, ya sea esta la de un acontecimiento público o personal. Desde el cuerpo y con el cuerpo, muchos artistas hemos incursionado en esta deriva con el afán de no olvidar, o mejor dicho, para recordar a través de la materialización de lo inaprensible, para catalizar el tiempo, lo efímero de la vida y la fragilidad de la memoria.

Tenemos la necesidad de documentar el aquí y el ahora, las superficies de memoria que recubren a las personas y los objetos con una piel sensible a ser grabada, a retener los signos del tiempo. Cuando pensamos en un pasado, no sólo nos remitimos a una estancia anterior y lejana, sino, al minuto que acaba de pasar, al instante fugaz que se va y deja una huella en nosotros. En tanto, esta historia escrita en la piel es un relato cargado simbólicamente, el cual nos hemos registrado, transferido y archivado.

En la presente investigación nos identificamos con artistas que documentan el rastro efímero de la vida, coleccionamos fragmentos de memoria de personas anónimas para expandir la grafica encarnada en su cuerpo y en las superficies sensibles.

De esa manera el sentido de la historia no es narrativo ni lineal, sino por el contrario, un puzle de partes significantes que dialogan dialécticamente entre sí, siempre abiertas a la interpretación y reinscripción en múltiples materiales y superficies. En suma, consideramos que somos artistas nómadas recolectores, porque allá donde vayamos traemos en nuestra mochila un acerbo de fragmentos de memoria, de huellas del tiempo y 
relatos corporales que no se traducen a palabras, sino a modo texturas epidérmicas, pero ante todo en experiencias compartidas gracias al camino que la latexgrafía ha trazado hasta aquí.

Sabemos que en este breve recorrido han quedado un sinfín de autores y artistas cuya obra puede amalgamar también los conceptos tratados hasta el momento, empero, hemos sido sinceros con nuestro proceso, y hemos decidido incluir aquellos que han impactado directamente nuestro proceso creativo y discurso teórico conceptual. Como es sabido, esta revisión sólo ilustra la punta del iceberg de un denso y rico tejido artístico, en los que muchos han colaborado, tanto artistas emergentes -como nosotros - como figuras internacionales. En esta comunidad de la que nos sentimos parte, construimos los nuevos paradigmas de nuestro tiempo: el estado de la gráfica corporal expandida en un territorio global. 


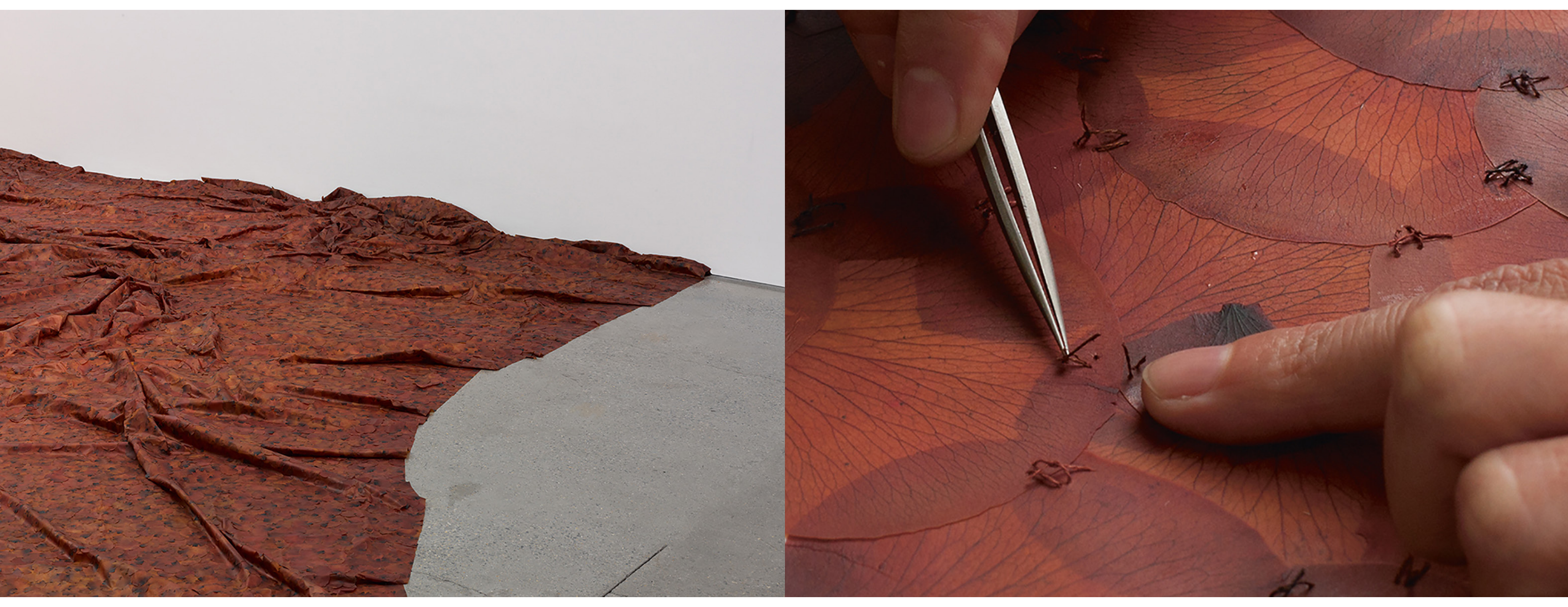

Fig. 2.28. Doris Salcedo, A lor de piel, Instalación de pétalos tejidos entre sí con costuras quirúrgicas, (2011-2012) 


\section{TERCERA PARTE}

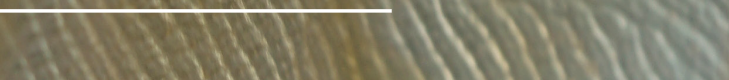

inthorimin

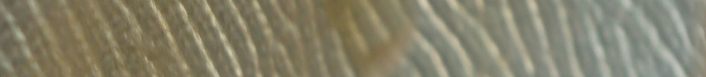
(1) W.

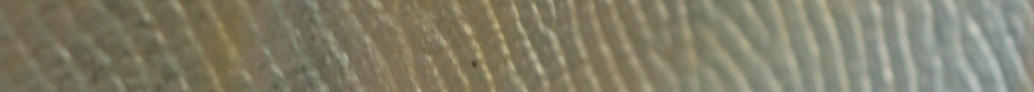

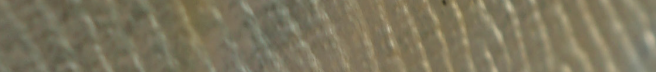

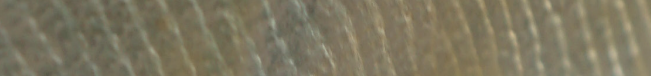

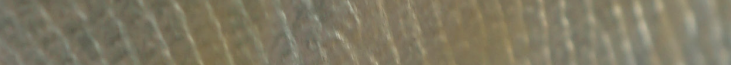




\section{CORPUS DE OBRA}

Cuando concluimos el máster en Producción Artística en la UPV en el año 2011, éramos conscientes de que estábamos ante el principio de una nueva etapa, queríamos afianzar y ampliar las bases teórico conceptuales y los recursos técnicos de la latexgrafía, desde la concepción y ejecución de un corpus de obra respaldada por una investigación basada en las artes. El corpus de obra, con el que hoy contamos, se ha venido gestando desde entonces, y en su mayoría formalizado dentro del marco del proyecto Embodied Memory, el cual fue producto del premio recibido en la Trienal Internacional de Grabado de Cracovia en el 2018 (MTG), quienes, en conjunto con el Museo de Arte Moderno de Bydgoszcz (MOB), nos dieron la gran oportunidad de realizar una exposición individual, del 9 de noviembre del 2019, al 19 de enero del 2020.

En esta tercera parte de la tesis, dedicada a la investigación artística, presentamos los resultados obtenidos a partir de la propuesta expositiva antes mencionada, y los últimos avances realizados en relación a la latexgrafía, piezas desarrolladas en el transcurso del año 2021.

\subsection{METAFORIZACIÓN DE EMBODIED MEMORY}

Como ya hemos escrito a lo largo de la investigación, no concebimos nuestro trabajo sin la colaboración participativa del público y la imbricación del contexto sociocultural en el que se lleva a cabo. Así fue el caso de Embodied Memory, un proyecto que se inició desde el mismo momento en que emprendimos nuestro primer viaje al MOB, apenas dos días después de la obtención del premio (MTG). En esta primera toma de contacto, conocimos al equipo de trabajo y el espacio de la galería en la que presentaríamos los resultados de nuestra investigación. Durante esta corta estancia, tomamos nota de los aspectos socioculturales e históricos más relevantes, así como de las cualidades materiales y dimensiones espaciales de la sala que albergaría nuestra instalación; un formato que nos permitió agrupar la naturaleza de los estímulos y la información recabada, con la identidad gráfica de nuestro trabajo. 
A partir de los acuerdos que establecimos con las autoridades del MOB, se planificaron varias visitas a Bydgoszcz, para llevar a cabo los distintos talleres latexgráficos y coordinar, conjuntamente con los comisarios del departamento de artes gráficas, el avance y desarrollo de la exposición y de la publicación del catálogo. Así, la creación artística, se gesta desde el insitu y continúa a lo largo del proceso de organización y diseño museográfico; tal y como lo expresa Barbara Chojnacka (2019), comisaria principal de la muestra en su texto "Concept in process, an exhibition in progress" ${ }^{\text {: }}$

La imaginación de la artista se alimenta de lugares específicos, en donde ella ha estado, su pasado y presente, sus comunidades. Ella preserva historias únicas de los lugares que visita y de las personas que conoce, registrando en sus improntas - los fragmentos de realidad. Estos son el punto de partida de un trabajo - bien pensado-, donde a manera de objetos e instalaciones se constituye la totalidad de una obra completa (p.15)

En nuestra investigación concebimos la producción artística como un tejido flexible que se construye con el tiempo, en cuya trama y urdimbre entrelazamos los aspectos formales, conceptuales y vivenciales. En el proceso creativo no nos ceñimos a una primera idea, sino que dialogamos constantemente con la trasformación de las metáforas y lo que intrínsecamente potencian los materiales dentro del proceso de ejecución. La construcción de metáforas visuales de nuestro trabajo se plasma mediante pruebas de materiales y bocetos hechos a mano, un método que favorece la manera particular en que pensamos las imágenes. Un proceso creativo, a través del cual articulamos la forma simbólica de nuestra imaginación. Tal y como se observa, en la primera etapa del proceso creativo, se manejaban ideas sueltas, algunas quedaron en el camino, y otras, fueron transformándose para alcanzar el resultado expuesto posteriormente (Fig. 3.1).

${ }^{9} \mathrm{E}$ l texto original está publicado en inglés y para efectos de esta investigación Priscilla Romero ha realizado la traducción al castellano de la cita:

The artist's imagination is fueled by specific places, in which she stays, their past and present, their communities. She preserves the unique stories of the places she visited and people she met, taking their imprints- fragments of reality. They are the starting point to specific, well-thought-out works, which in the form of objects or installations constitute a complete artwork. (Barbara Chojnacka, 2019, p.15) 

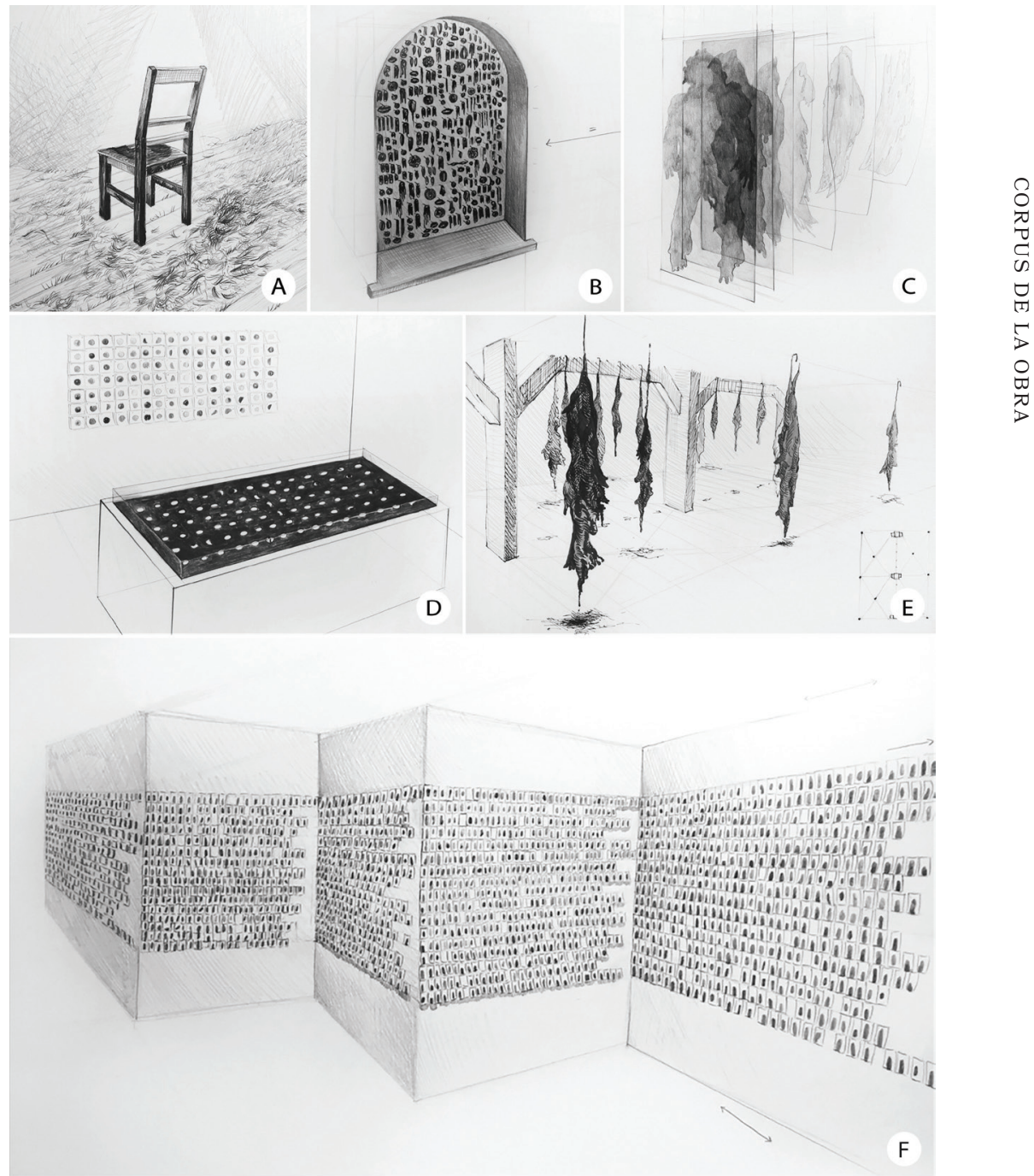

Fig. 3.1. I etapa de la construcción metafórica del proceso gráfico de Embodied Memory, (2018). Las ideas a las que se refieren imágenes A, B y C, no se llegaron a concretar. La idea A, corresponde a una instalación con cabello humano que planteaba reunir diferentes muestras para hablar de la identidad, la idea B gira en torno al concepto del exvoto como unidad simbólica del cuerpo fragmentado, y la idea $\mathrm{C}$, la transmutación de la huella de la piel humana en textura natural, ya sea esta madera $\mathrm{u}$ otras superficies, para reflexionar acerca de las fronteras entre el mundo y el ser humano. Por su parte, la D, E y F, fueron el precedente visual de los proyectos Livinǵ treasure, Second skin y Digital archive, respectivamente. 
Hasta este momento, teníamos tres grandes generadores de obra, el primero correspondió a la recolección de matrices latexgráficas de los dedos de la comunidad de voluntarios, el segundo, el registro de las superficies de las columnas patrimoniales de madera del MOB, y el tercero, consistía en la ejecución de una matriz latexgráfica de nuestro propio cuerpo, siendo este último, el que se replicaría para dar origen a diversas obras de gran formato, como por ejemplo la $\mathrm{C}$ y la E. Sin embargo, este proceso técnico no se pudo concluir satisfactoriamente, ya que sufrimos una crisis de ansiedad que produjo la pérdida de conocimiento mientras realizaban el molde de nuestro cuerpo, el mismo que tuvieron que desprender a pedazos para que volviéramos en si, ya que al tener cubierto la mayoría de nuestros poros, el proceso natural de transpiración de la piel se había obstruido. Estos fragmentos luego se utilizaron a lo largo de varias impresiones, y en obras específicas como Second Skin (2019).

Este suceso supuso un giro que modificó por completo la muestra, a partir de lo cual decidimos concentrarnos en potenciar los vínculos con Bydgoszcz. De este modo, gran porcentaje de las piezas que componen Embodied Memory cuentan con una participación directa de la ciudadanía y giran alrededor de componentes simbólicos para su cultura, por ejemplo, la resignificación de las monedas de oro encontradas recientemente bajo el suelo de la catedral, así como la importancia de la industria maderera para el desarrollo socioeconómico del lugar.

Después de nuestra segunda estancia en la ciudad, pudimos madurar mejor nuestras ideas, en parte, gracias a la empatía que surgió en el contacto que tuvimos con las personas durante nuestras charlas y el proceso latexgráfico. Este dato pareciera ser anecdótico, pero en el marco de nuestra investigación es imprescindible, ya que se crea un sentido de comunidad en torno a la creación artística, un acto que lejos de ser un cometido exclusivo propio de nuestra práctica, se convirtió en un proyecto compartido del que todos se sienten parte al dejar-literalmente- su huella en él. 
A continuación, haremos un breve recorrido - a manera de una visita guiada- por el desarrollo del proceso creativo, a partir del análisis de imágenes que consideramos diferenciales para el presente trabajo. Iniciamos este recorrido ubicando cada una de las obras en el plano de la sala del museo, la cual mide aproximadamente $265 \mathrm{~m}^{2}$. En las vistas de planta, destacamos las diferentes proyecciones realizadas mediante dibujos y su respectivo resultado final, en los que enfatizamos la distribución, el montaje, la iluminación y los recorridos visuales en el esquema museográfico. De igual manera, al hilo del discurso, iremos planteando las diferentes lecturas metafóricas que se articulan al enlazar los elementos formales, conceptuales y procesuales, así como la indisoluble imbricación con el contexto en el que se emplaza nuestra producción artística.

\subsubsection{DIGITAL ARCHIVE /ARCHIVO DIGITAL}

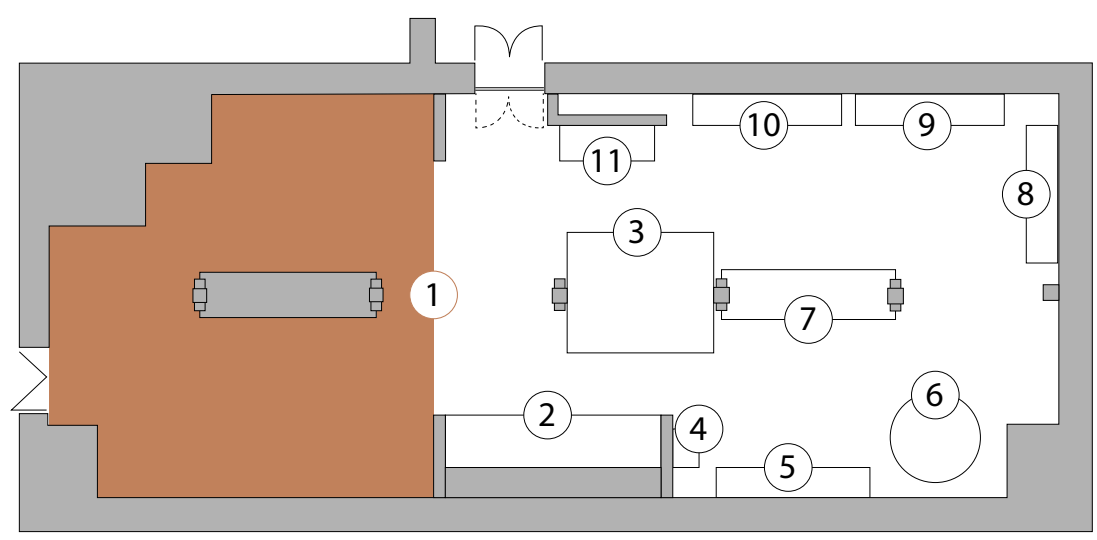

Fig. 3.2. Vista de planta de la galería del MOB. Con el número 1, ubicamos el proyecto Archivo dióital en el plano, para que se aprecie su dimensión y emplazamiento. Esta instalación, es la que recibe al público en la entrada principal de la sala. Abarcando un área aproximada de $75 \mathrm{~m}^{2}$ en total. 

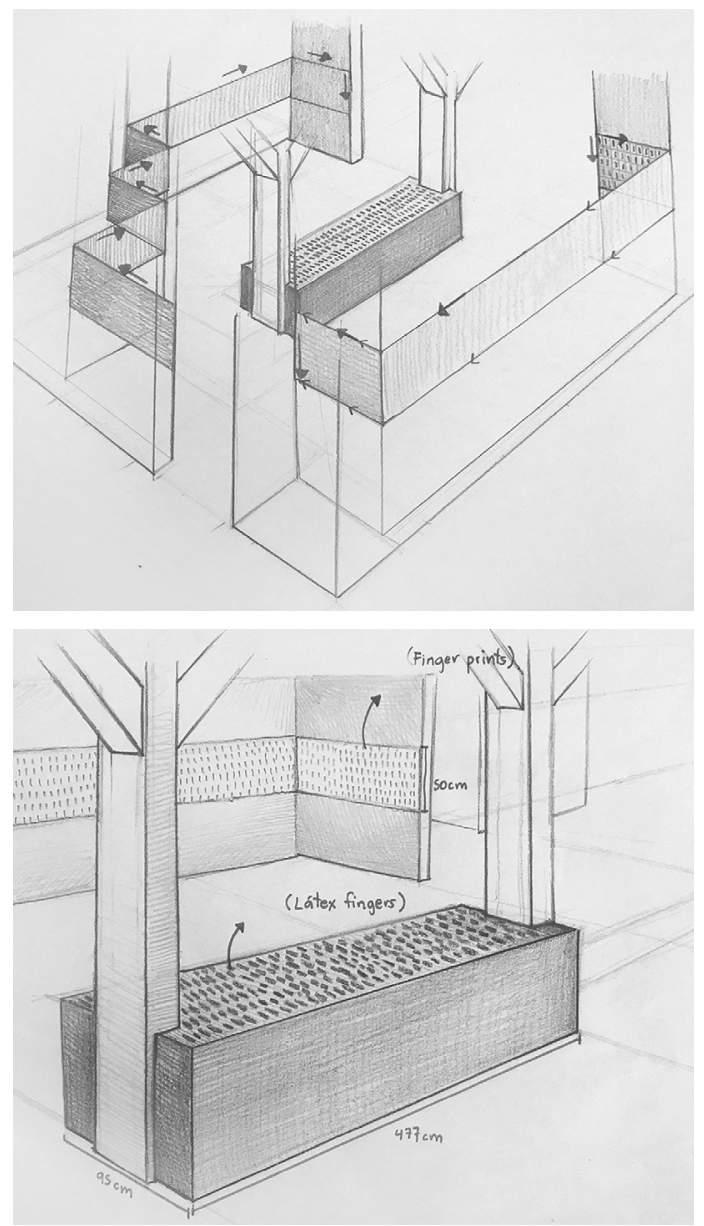

Fig. 3.3. En estos bocetos proyectamos cómo se iban a distribuir los dos componentes de la instalación. A la izquierda observamos un friso con más de 3000 impresiones que recorre linealmente los 30m lineales del espacio. En el dibujo de la derecha, se diseña un adosado a las columnas de madera, que quedaría como una isla dentro del espacio, para que se observaran las matrices latexgráficos desde varios ángulos. Sobre esta área de unos $5 \mathrm{~m}^{2}$, se alinearon más de 350 dedos de látex, como una parte representativa del acervo completo que supera las 500 unidades. 


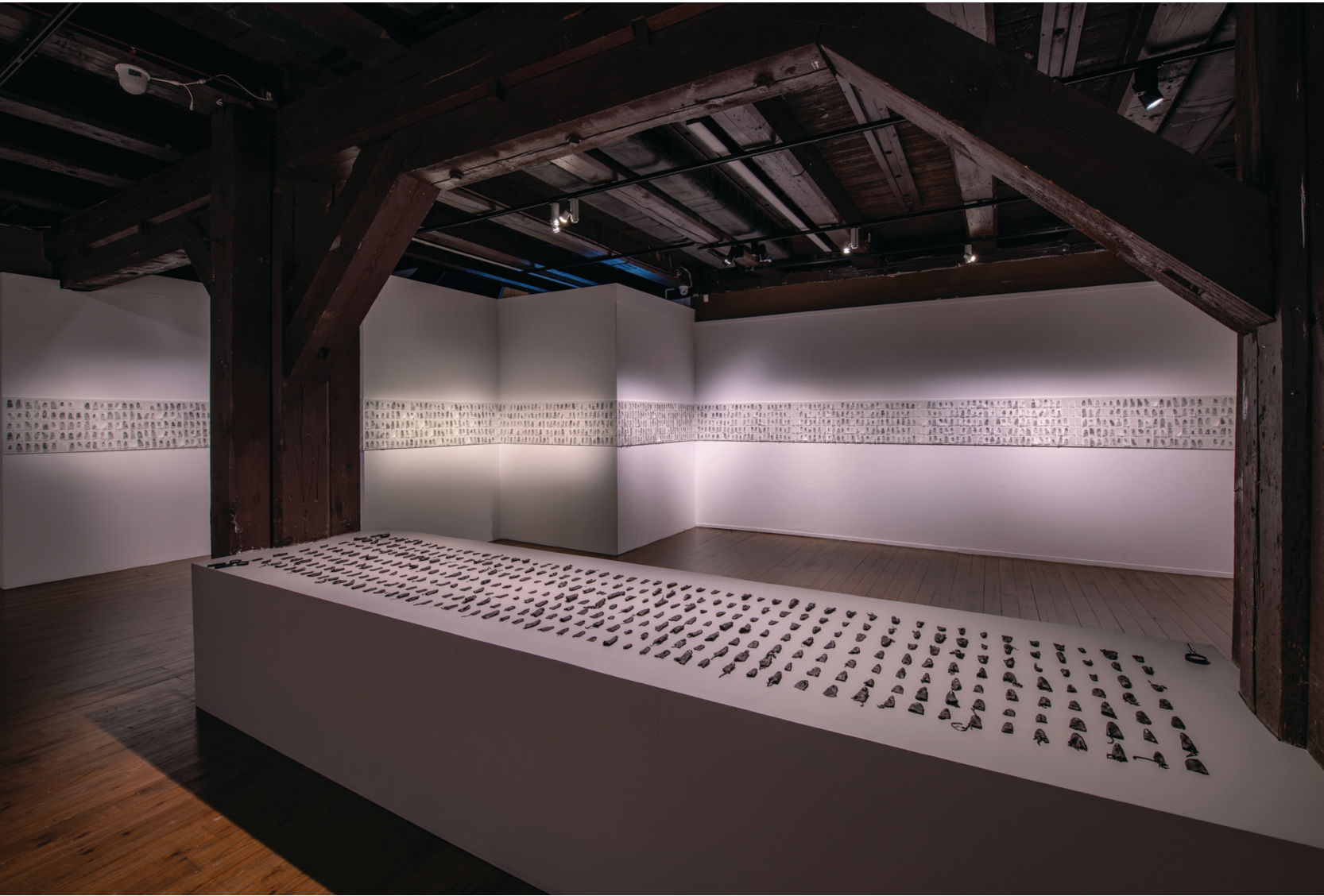

Al entrar en la sala nos recibe Archivo digital (2019), un proyecto que tiene por subtítulo "Un memorial de la condición humana" (Fig. 3.4). Este trabajo gira en torno a la idea de una identidad diversa y heterogénea, compuesta por cientos de personas, que, sin importar las simbolizaciones de toda índole -a las que pueden estar sujetas-, conviven metafóricamente en el espacio de la instalación. La forma en que está articulado el diseño museográfico, propone dos componentes, el primero es un friso que envuelve la sala, compuesto por aproximadamente 3000 huellas latexgráficas de 5x8cm (tamaño estándar de una tarjeta de visita), meticulosamente colocadas con alfileres a la pared, cual si estas fueran nombres grabados en un monumento póstumo. El segundo componente remite a la dialéctica entre las improntas y sus matrices colocadas en medio de la sala. Los casi 400 dedos de látex, se exponen como si fueran 
exvotos, en tanto que objetos donados a manera de ofrenda dentro del marco del rito técnico. Tanto las huellas y matrices latexgráficas resguardan su lugar propio, no hay un dedo que se sobreponga al otro, ni una matriz que invada el espacio de al lado, no existe la yuxtaposición en este orden reticular, en el que podemos estar juntos, pero no acumulados ni amontonados. (Figs. 3.5 y 3.6).

Fig.3.5. Detalle del friso de huellas latexgráficas

Fig.3.6. Detalle del montaje de las matrices latexgráficas. 


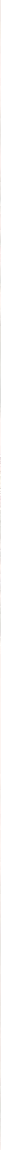

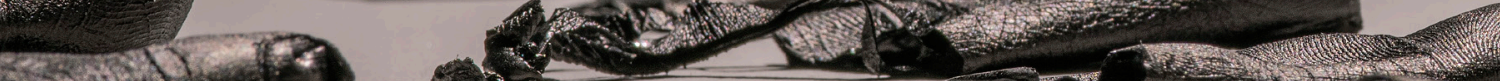

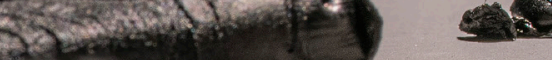

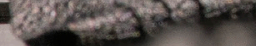


Esta propuesta espacial es una metáfora visual que invita a repensar las relaciones humanas hoy día, cómo nos percibimos dentro de las colectividades más diversas, y también cómo -paradójicamente- cada día estamos más conectados pero menos en contacto, en una sociedad en la que desaparecen diariamente los ritos de interacción corporal, tan importantes para crear los lazos de comunidad y perpetuar la cultura. Archivo digital, es, por tanto, una propuesta que nace de la empatía, la tolerancia y la coautoría entre el público y nosotros. Consideramos que es un gran homenaje a la memoria encarnada de los múltiples encuentros que hemos tenido a lo largo de nuestra investigación, en los que cada matriz latexgráfica es el remanente simbólico y material del contacto piel con piel-. Un contacto, que, hasta ahora, ha sido con cerca de 500 personas de más de 20 nacionalidades y con rangos de edad que van desde los 2 hasta los 95 años; un grupo significativo del cual, 150 son habitantes de Bydgoszcz.

Como parte del diseño museográfico y el montaje, planteamos una propuesta sobria y un tanto solemne, con luz tenue y puntual, y colores neutros que no compitieran con la delicada obra impresa sobre papel o la rotunda presencia que imponen las matrices expuestas; todo esto armonizado con una sonata de chelo interpretada por la orquesta sinfónica juvenil de la ciudad, música que se programó para acompañar el silencio durante todos los días que estuvo abierta la muestra. Todo el conjunto está a mano del público, no hay vidrios, marcos, capelos o nichos que resguarden la integridad de la obra; porque lo que nos interesa es la interacción máxima entre las personas y las imágenes; razón por la que repartimos varias lupas en el espacio, para que aquellos curiosos pudieran divertirse y jugar a los detectives, hurgando entre este gran documento probatorio de identidad.

Gracias a las características matéricas del papel gampi -de apenas 12g-, se crea una estática con el más mínimo aliento, en el que los fragmentos reaccionan al movimiento como si fueran los bellos de nuestro cuerpo al ponerse la piel de gallina. Así, las miles de improntas, se mueven dinámicamente cuando alguien se acerca, causando, en este acto, una inmediata reacción empática con el público. Otro punto importante, es que a pesar de que un determinado número de impresiones provienen de 
una misma matriz, ninguno de estos registros es idéntico, ni procuramos que lo sea, todo lo contrario, sacamos ventaja de las cualidades que nos da el material para girar el molde semicilíndrico en distintas posiciones y así obtener siempre los registros diferentes de ambas caras de cada dedo, en la misma tirada. De esta manera, provocamos variantes gráficas que expanden el potencial de cada matriz latexgráfica; cada giro es para nosotros, un pliegue visual que no hace más que subrayar el valor de la diferencia y la versatilidad del medio, al replegarse y multiplicarse modularmente, acoplándose al espacio como una segunda piel (Fig. 3.7).

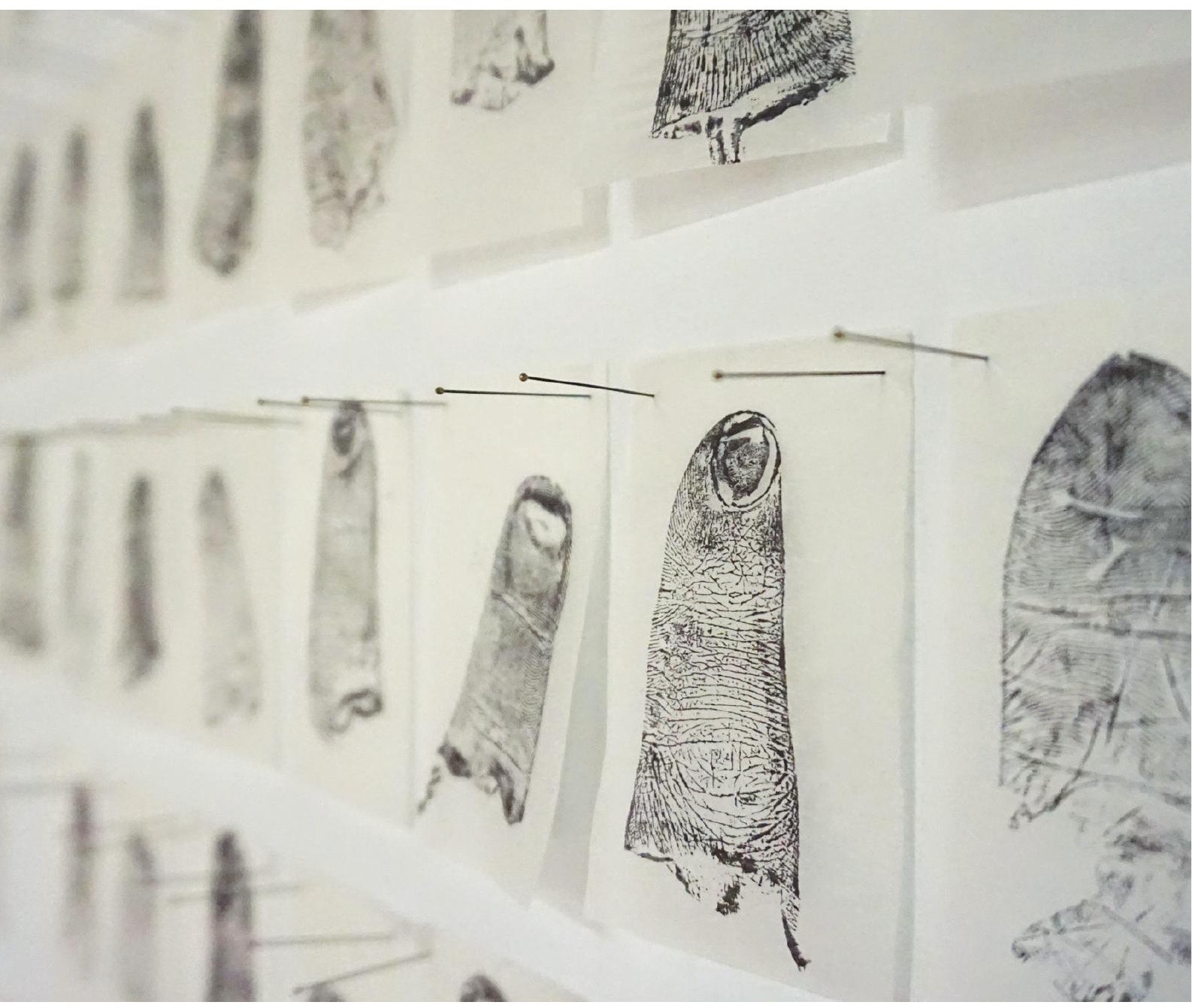

Fig.3.7. Detalle del montaje de las improntas que conforman el friso de Archivo diǵital. 
Este trabajo se concibe como un documento de archivo, un proyecto memorial que no ha hecho más que empezar, ya que nuestra idea es que se extienda allá donde vayamos, seguir materializando las huellas de los encuentros con las personas y sus contextos. Cada huella es una letra dentro de este enorme texto escrito con la gráfica de la piel, un signo de un abecedario infinito en el que no hay consonantes ni vocales, donde el pasado se conjuga con el presente, un espacio singular que deviene plural, donde no existen más reglas gramaticales que la sintaxis que emana de la forma y su potencial para comunicar -estímulos y sensaciones- que trascienden cualquier idioma de las personas que conforman las matrices primigenias, para dar un paso al frente y hablarnos en el lenguaje que dicta el tiempo y la memoria corporal. La misma que se transmuta de un lugar a otro, borrando los límites simbólicos y abriendo las fronteras imaginarias del sentido del cuerpo y la imagen encarnada en la piel.

\subsubsection{LIVING TREASURE/TESORO VIVIENTE}

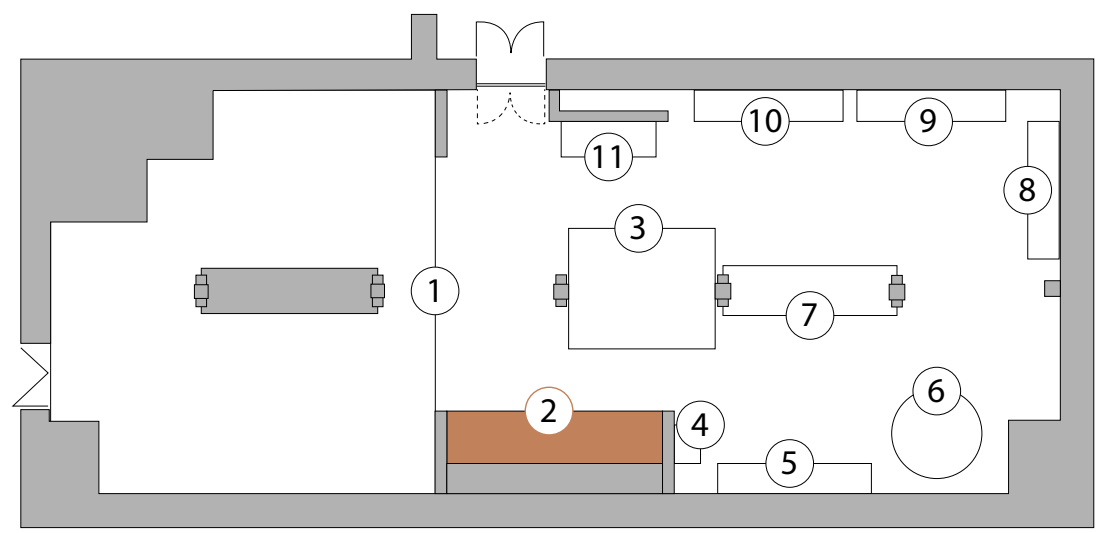

Fig.3.8. Vista de planta de la galería del MOB. Con el número 2, ubicamos el proyecto Tesoro viviente en el plano, para que se aprecie su dimensión y emplazamiento. Esta instalación, continúa con el recorrido, después de Archivo digital, abarcando un área aproximada de $11 \mathrm{~m}^{2}$ en total. 


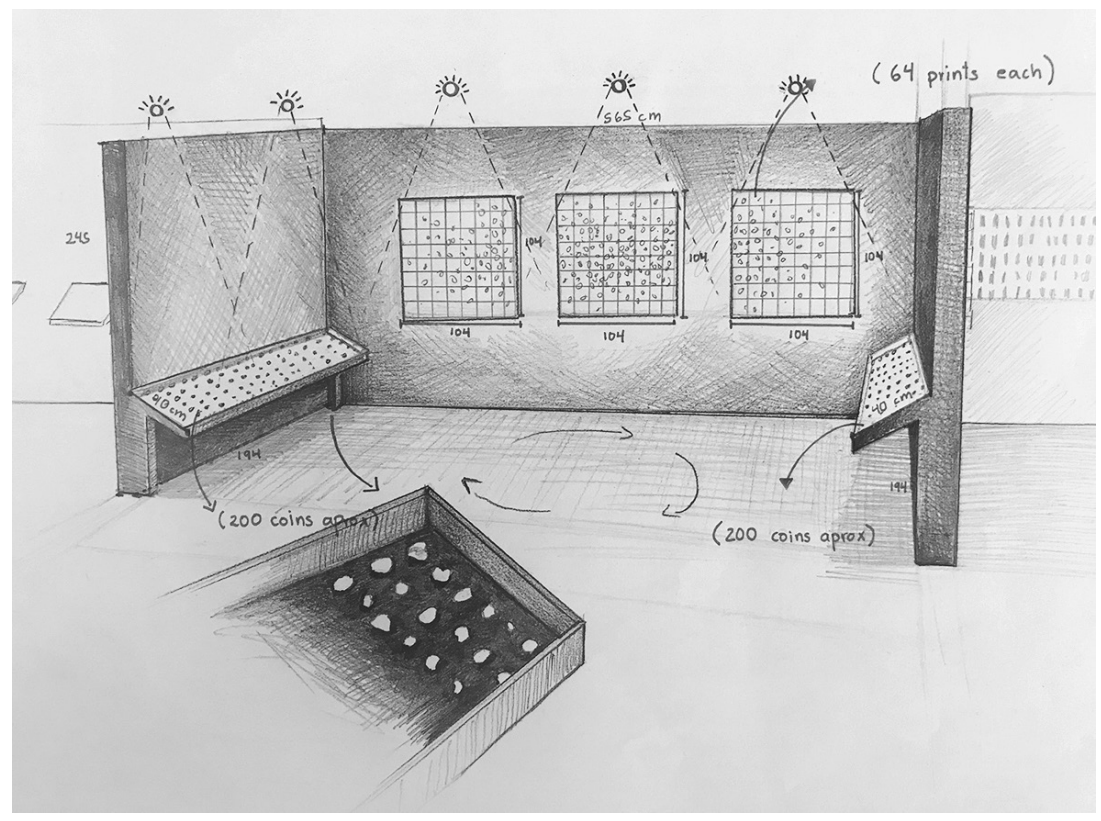

0
0
0
0
0
0
0
17
5
0
0
0
0
1

Fig.3.9. En este boceto se proyecta la distribución y detalles de montaje de los dos componentes de la instalación. Se crea un espacio íntimo con luz tenue, para realzar las diferentes opacidades y brillos de las monedas y las improntas sobre papel. Se diseñan los dispositivos donde se ubican las monedas, emulando la manera en que se exhiben las monedas de oro en el museo de arqueología. 
En enero del 2018 descubrieron un tesoro de monedas de oro bajo el suelo de la catedral de Bydgoszcz, mientras realizaban obras de restauración en este patrimonio arquitectónico. Desde ese entonces, esta colección de monedas pasó a manos del MOB, como parte de su acervo de piezas arqueológicas. Para los pobladores de la ciudad representó todo un hallazgo, motivo por el cual le llaman popularmente El tesoro de Bydgószcz y a partir de este juego de palabras bautizamos nuestro trabajo como el Tesoro viviente (2019), para hacer referencia, a que la riqueza más grande no está en el valor del oro, sino que yace en la piel de sus ciudadanos, su historia de vida y resiliencia (Fig. 3.10).

El giro que planteamos, traslada la perspectiva del valor y el poder de los objetos a la memoria histórica encarnada en las personas de una

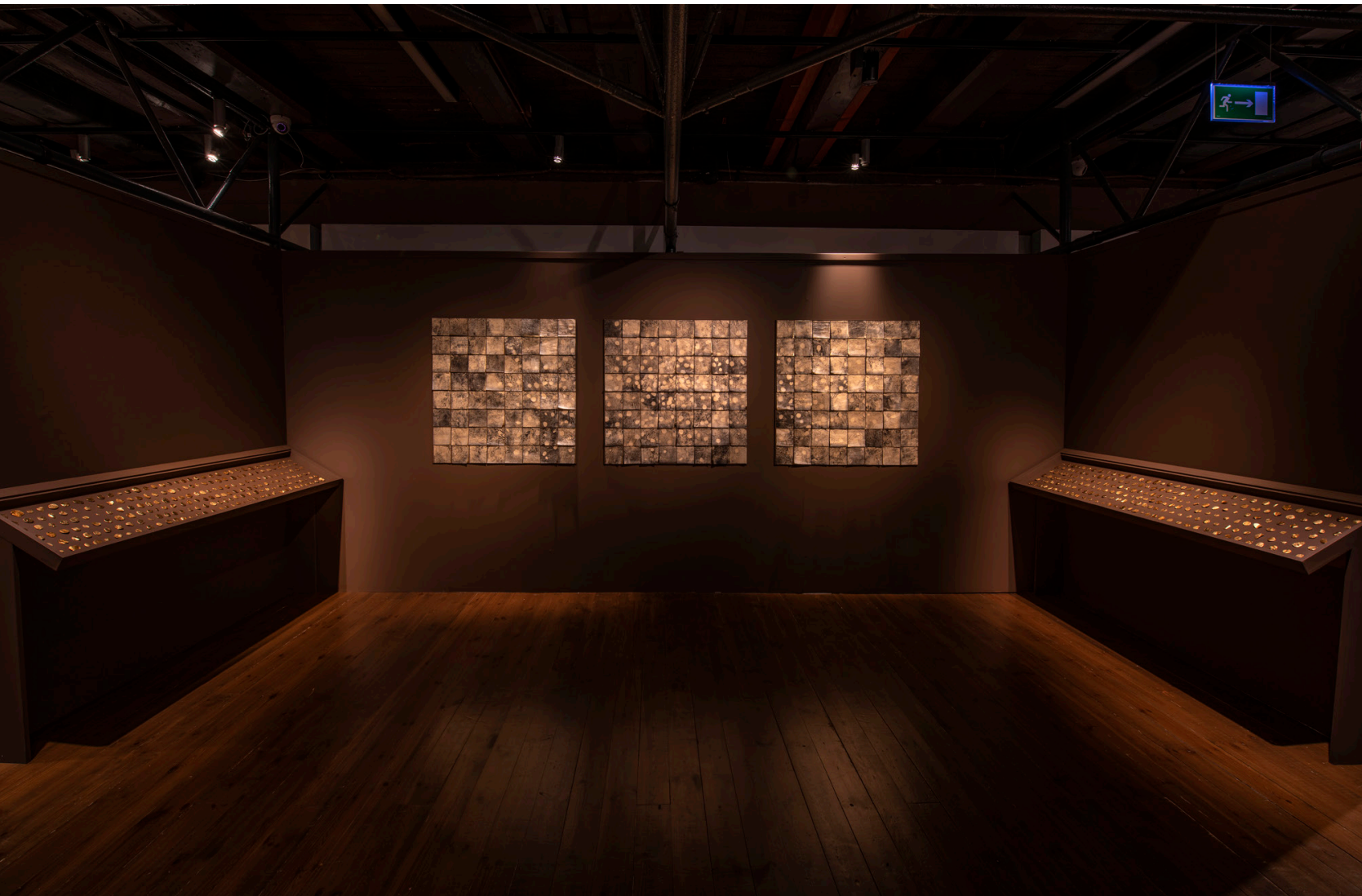

Fig. 3.10. Priscilla Romero, Tesoro viviente, instalación, 2019. 
comunidad. Para hacerlo, toma como punto de partida el relato histórico y la huella de la piel, en tanto que registro gráfico de la existencia de cada quién. Gracias a la gran cantidad de matrices latexgráficas, registradas durante nuestros encuentros, contamos con materia prima para recrear el montaje y apariencia, que tienen las monedas de oro en el museo, y acuñamos nuestras propias réplicas, con cara y cruz, pero esta vez con un material más bruto que el oro: la escayola. Así, al dejar una pequeña porción de este material y presionarlo entre dos matrices, las últimas dejan su impronta sobre la escayola al fraguar. Un proceso simple, que involucra la matriz latexgráfica como emisora y la escayola -como materia receptora. Así, obtenemos una pequeña moneda ficticia ultradelgada; frágil y sutil, con unas huellas impecablemente transferidas, la cual se dora manualmente a modo de trampantojo (Fig.3.11 y 3.12).

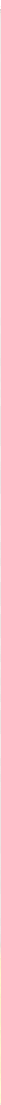

Fig.3.11. Detalle de las improntas monedas ficticias doradas. 
Adjunto a este proyecto tridimensional, también exponemos un tríptico de obra gráfica bidimensional, en la que hacemos el juego inverso, dejando en blanco el espacio de donde extrajimos cada moneda, a través del cual se trasluce - gracias a cualidades del gampi - el pan de oro que fue adherido al papel del fondo mediante chine-collé. De esta manera, cada módulo cuadrado, es la impresión de la matriz restante. Ambas piezas, se conciben como un conjunto, en el que -una vez más- se establece un diálogo imbricado entre los procesos técnicos y su poética visual, que se acentúa con el montaje, el color y la iluminación, para que solamente sobresalga el brillo dorado, y los diferentes niveles de opacidad, en un espacio íntimo y resguardado que se camufla con el ambiente, al tener la misma pintura que tiene el cielo raso y las estructuras de la galería (Fig. 3.12)

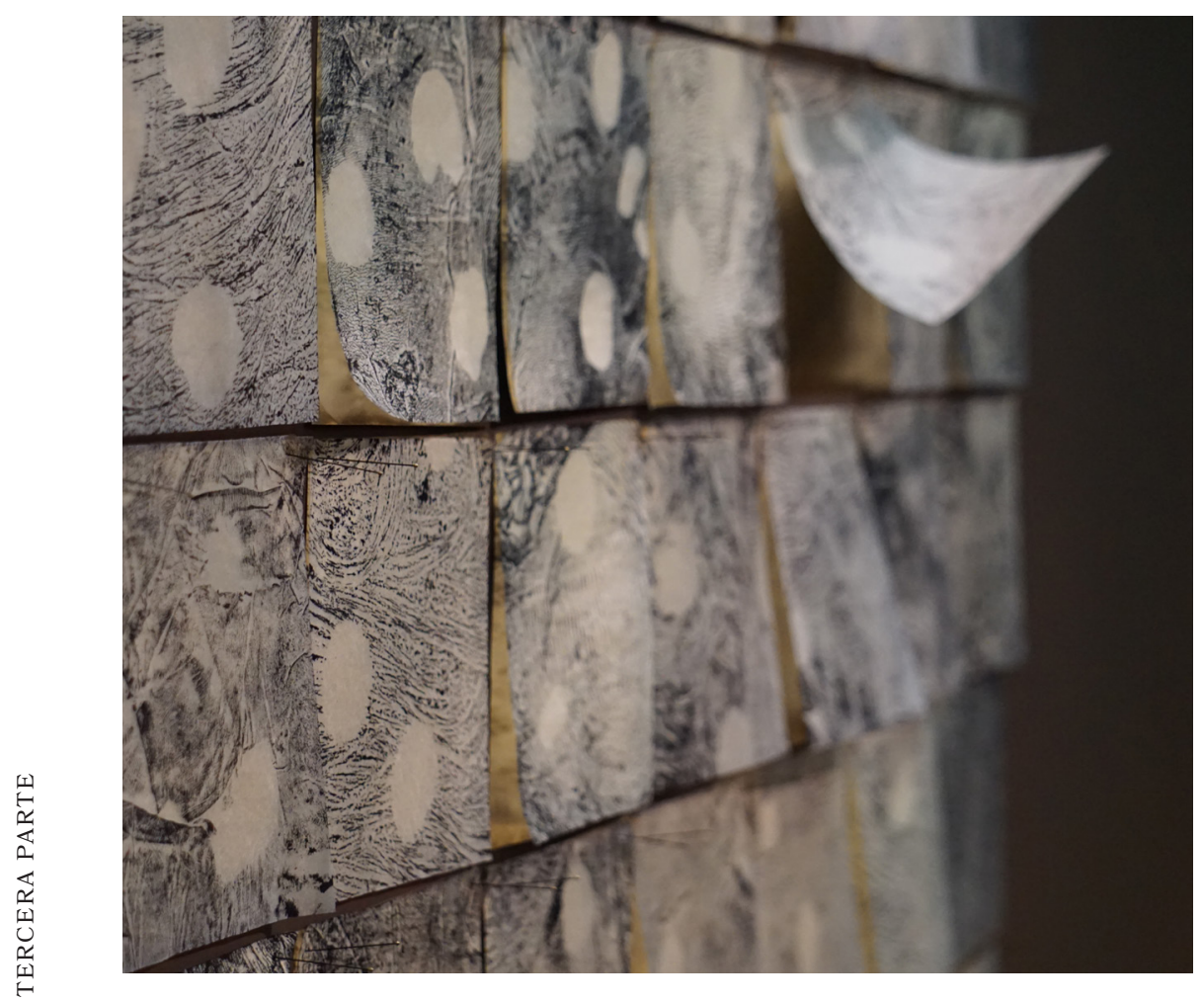

Fig. 3.12. Detalle del tríptico impreso donde se muestra la huella en negativo de las monedas, y el papel gampi con chine-collé dorado al fondo. 


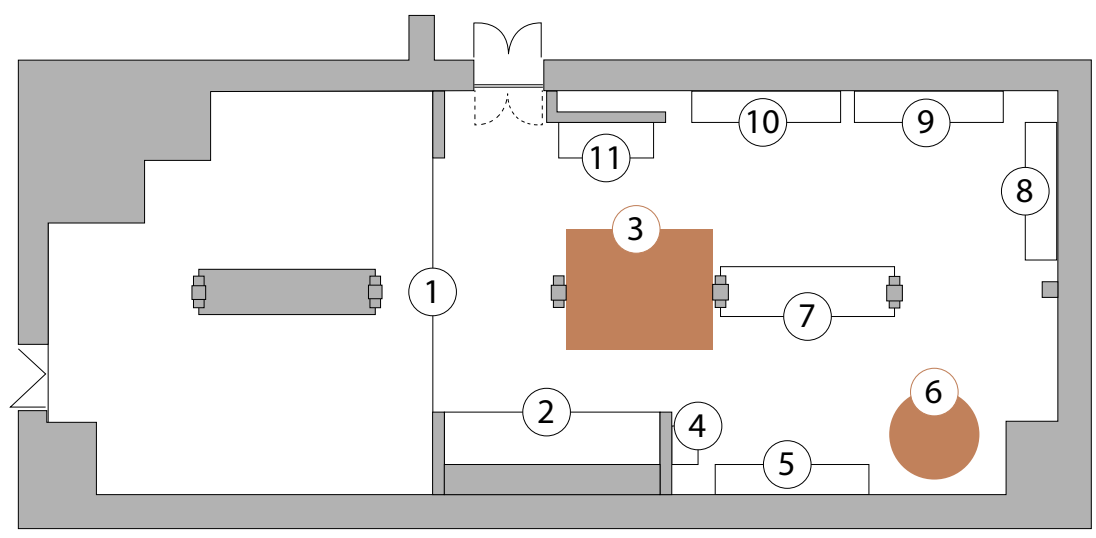

Fig.3.13. Vista de planta de la galería del MOB. Con el número 3, ubicamos el proyecto Astillas del tiempo y con el número 6, el conjunto Pieles madera. El primero abarca un área de $9 \mathrm{~m}^{2}$ y el segundo $8 \mathrm{~m}^{2}$ aproximadamente. El montaje se adecua al espacio, por lo que puede variar.
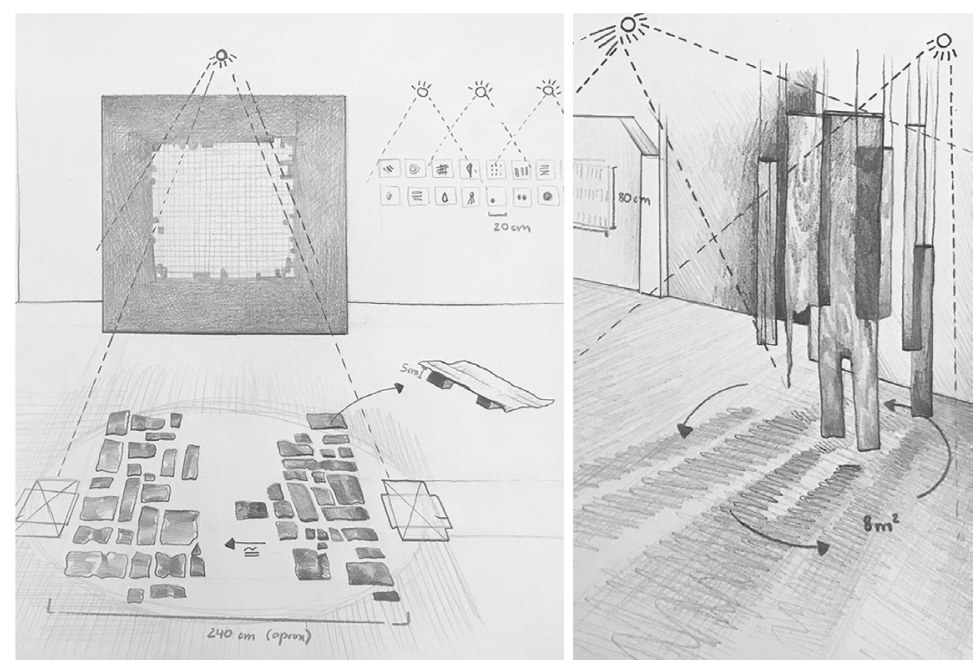

Fig.3.14. Boceto en el que se proyecta cómo y dónde se ubicarían las piezas. En el caso de Astillas del tiempo (izquierda), en un principio se pensó colocarla sobre pared, pero luego se consideró que al ser el piso de madera, habría un dialogo entre materias. Para eso se suspendieron las delgadas piezas de escayola con tacos de madera, para que diera la sensación de ingravidez. El caso de Pieles madera(derecha), se optó desde un principio por suspenderlas del cielo raso, para emular la verticalidad del árbol de donde proceden, y también como símbolo de resistencia ante el tiempo. Ambas composiciones se realizaron al término del montaje, ya que su solución final se ejecutó in situ. 


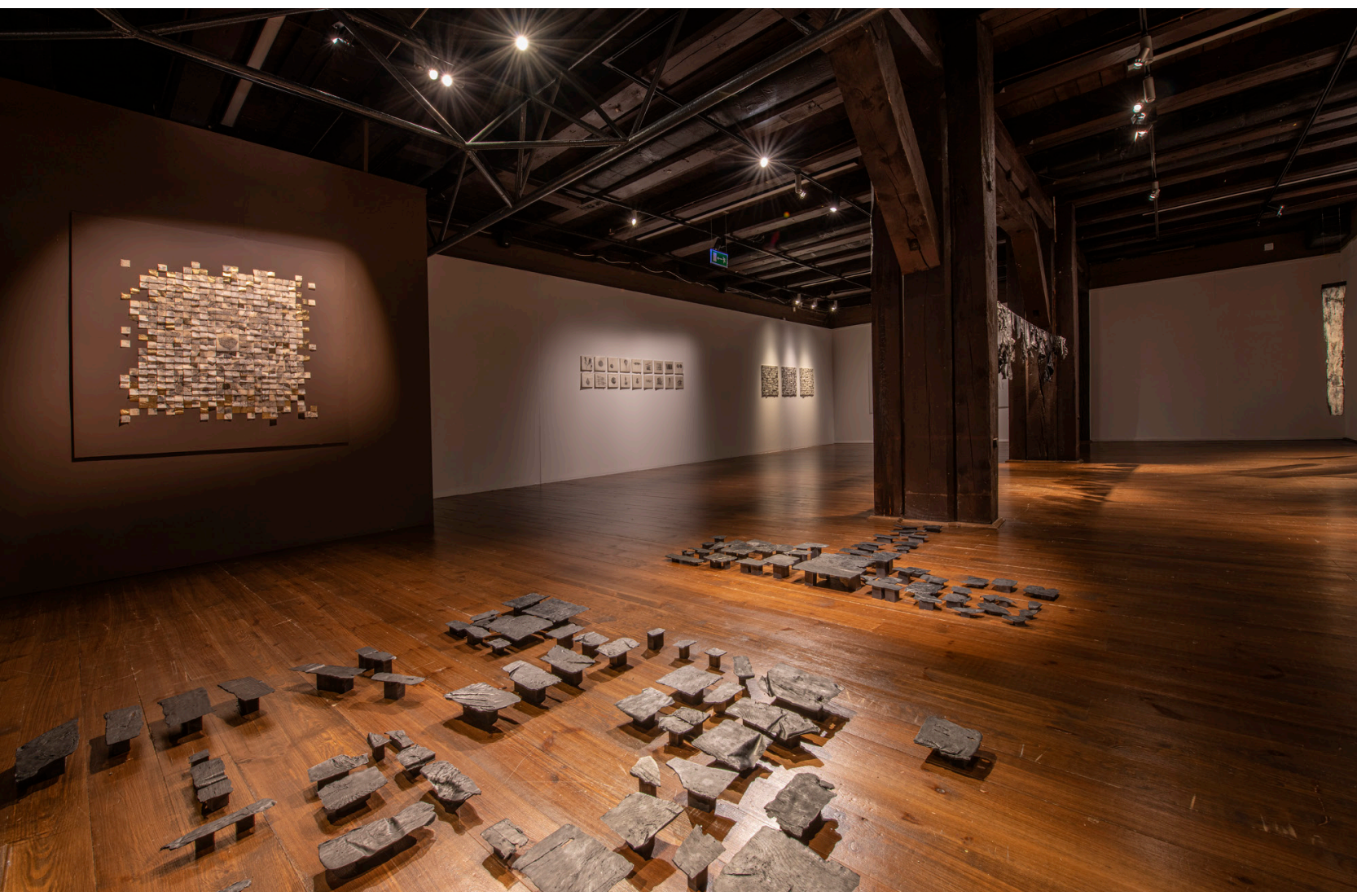

Fig.3.15. Priscilla Romero, Astillas del tiempo,

impresión latexgráfica sobre escayola, 2019

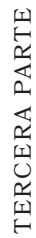

Fig.3.16. Priscilla Romero, Pieles madera, matrices latexgráficas provenientes de madera, 2019. 

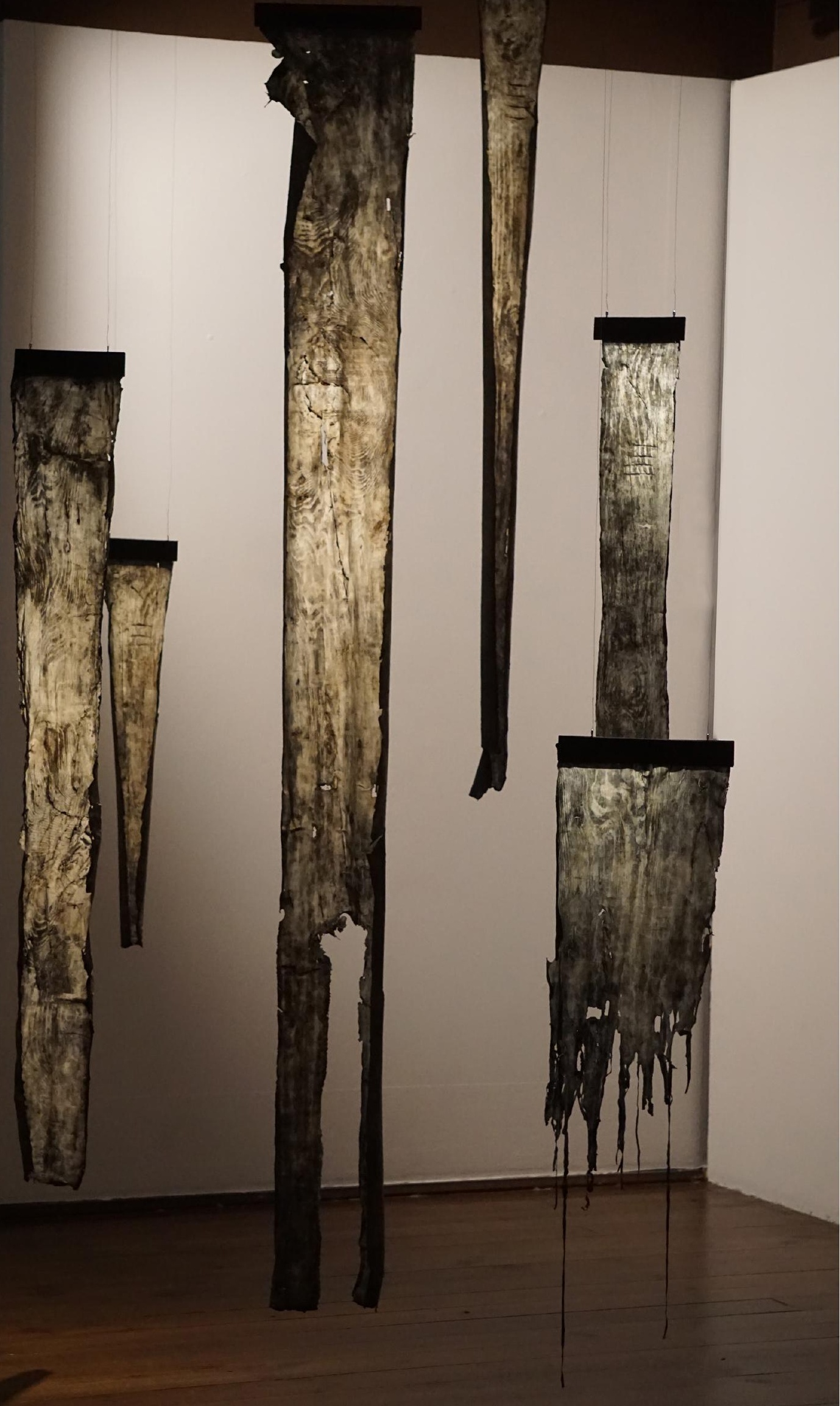
El río Brda rodea por completo la ciudad de Bydgoszcz, dibujando un sinfín de canales que construyen pequeños islotes, dentro de los cuales se encuentra el complejo museístico del MOB, en lo que fueron antiguos graneros. Del interior de Polonia provenían miles de troncos por el cauce del río, para que se industrializaran en esta ciudad. A partir de esta materia prima, se extraía la madera para la construcción de navieras, estructuras arquitectónicas y carbón natural. Durante la II guerra mundial, los edificios, que hoy son parte del museo, fueron parcialmente destruidos y quemados, pero los pobladores conservaron los robustos pilares de madera para reconstruir su ciudad. Sobre la piel de estas estructuras se encuentran grabadas las cicatrices del tiempo, el mismo, al que se resistieron a sucumbir.

Tomando en cuenta el valor simbólico de la madera para Bydgoszcz, realizamos una lectura plástica para resignificar el ciclo de vida de esta superficie, y dotarla de contenido poético. Un discurso, que, en este contexto, se interpreta como un tributo a su pasado, pero, sobre todo, a su presente. Ya que estas columnas de madera, siguen hoy en pie, siendo testigos vivientes de una historia, que muchos no vivieron para contar. Durante la segunda estancia en el MOB, llevamos a cabo un registro de estas columnas extrayendo de ellas varias matrices latexgráficas que se convirtieron en la obra Pieles madera (2019), desde las cuales se imprimieron sobre escayola los fragmentos que conforman Astillas del tiempo (2019), para formar un conjunto escultórico que remite a la naturaleza de su procedencia.

En Astillas del tiempo (Fig.3.15), las huellas positivas en escayola son una reproducción de la piel de las columnas, pero con un pequeño giro: éste recae en los sutiles pliegues que intencionalmente hemos provocado al jugar con la flexibilidad del látex, para que lo que en principio es una materia dura, visualmente se perciba con una apariencia viva, cual si fuera un tejido epidérmico carbonizado que emerge de las cenizas. La manera en que planteamos el montaje remite a un emplazamiento arqueológico, en el que cuidadosamente se trata de reconstruir una forma fragmentada, de la cual solo quedan algunas astillas. Técnicamente, después de haber 
fraguado, se impregna la escayola con la misma tinta que utilizamos para imprimir sobre papel, solo que esta vez, se sella el poro del material con polvo de grafito, siendo este último toque, el que le brinda la apariencia mineral del carbón.

En el caso de Pieles madera (Fig. 3.16), se conserva tal cual se desprendió de la matriz primigenia (las columnas), dándoles únicamente un pequeño baño de tinta negra, para luego quitar el exceso y evidenciar las texturas nítidamente registradas en el látex. En la disposición en la sala, estas caen colgadas del cielo raso, ocupando un espacio en el que el público puede transitar a través de ellas y tocarlas libremente. Ambas piezas hoy son parte de la colección del MOB, junto con el conjunto de Tesoro viviente. Todos estos proyectos son objetos transicionales, su composición se realiza in situ, de acuerdo al espacio y al diálogo con las demás obras. De modo que la forma en que se emplazó en Embodied Memory, es tan solo una de sus múltiples posibilidades. Sin embrago, el juego lumínico es imprescindible, tanto en las matrices de látex, para enfatizar su translucidez, como en las piezas de escayola, para que el contraste realce los pliegues y las texturas. 
Fig. 3.17. Detalle de montaje de Astillas del tiempo, donde se pueden apreciar los pliegues realizados durante la impresión latexgráfica.
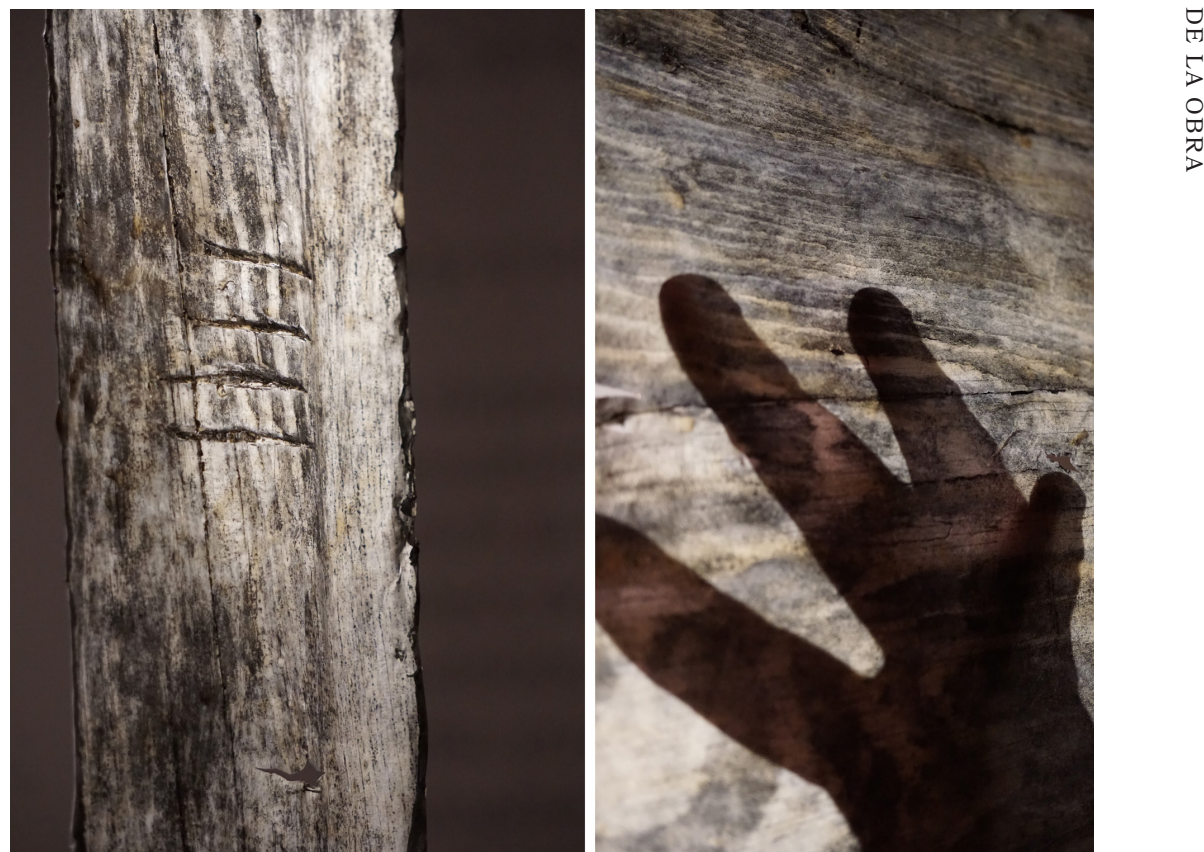

Fig.3.18. Detalle de las características materiales de las matrices latexgráficas de Pieles madera 


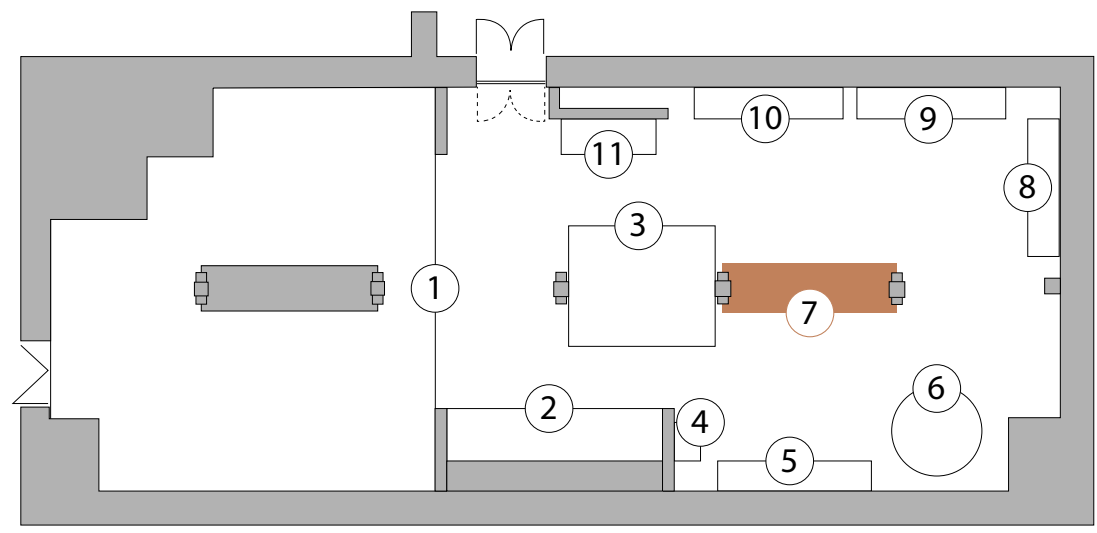

Fig. 3.19. Vista de planta de la galería del MOB. Con el número 7, ubicamos el proyecto Seǵunda piel en el plano, para que se aprecie su dimensión y emplazamiento. Esta instalación, puede ser transitada a través de la sala, de manera que los espectadores pueden tocar las matrices de látex o inadvertidamente rozarlas al atravesar el espacio. Abarca un área aproximada de $5 \mathrm{~m}^{2}$ en total, y su montaje y composición fue in situ.

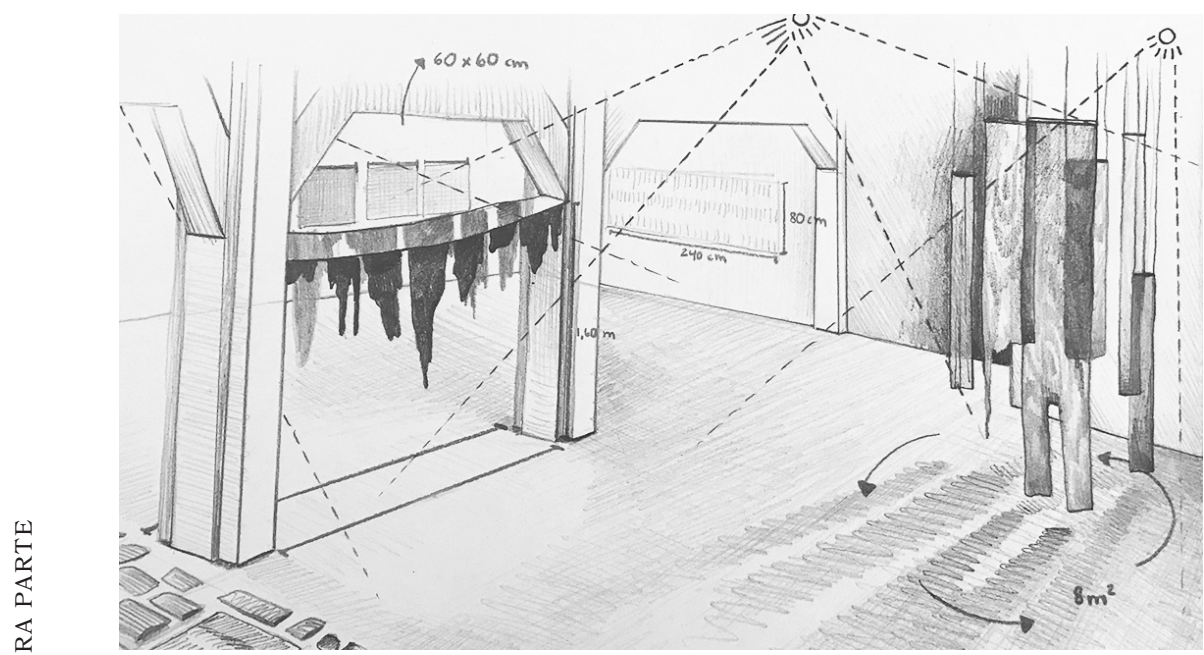

Fig.3.20 Boceto donde se proyecta el montaje de las pieles de látex cual si fueran trozos de cuero en una talabartería o ropa tendida. La idea es que estuvieran en contacto directo con el público sin interferencia alguna. Esta pieza está en diagonal a Pieles madera, conjunto con el que establece una relación formal y conceptual, al ser ambos mudas de cuerpos. 


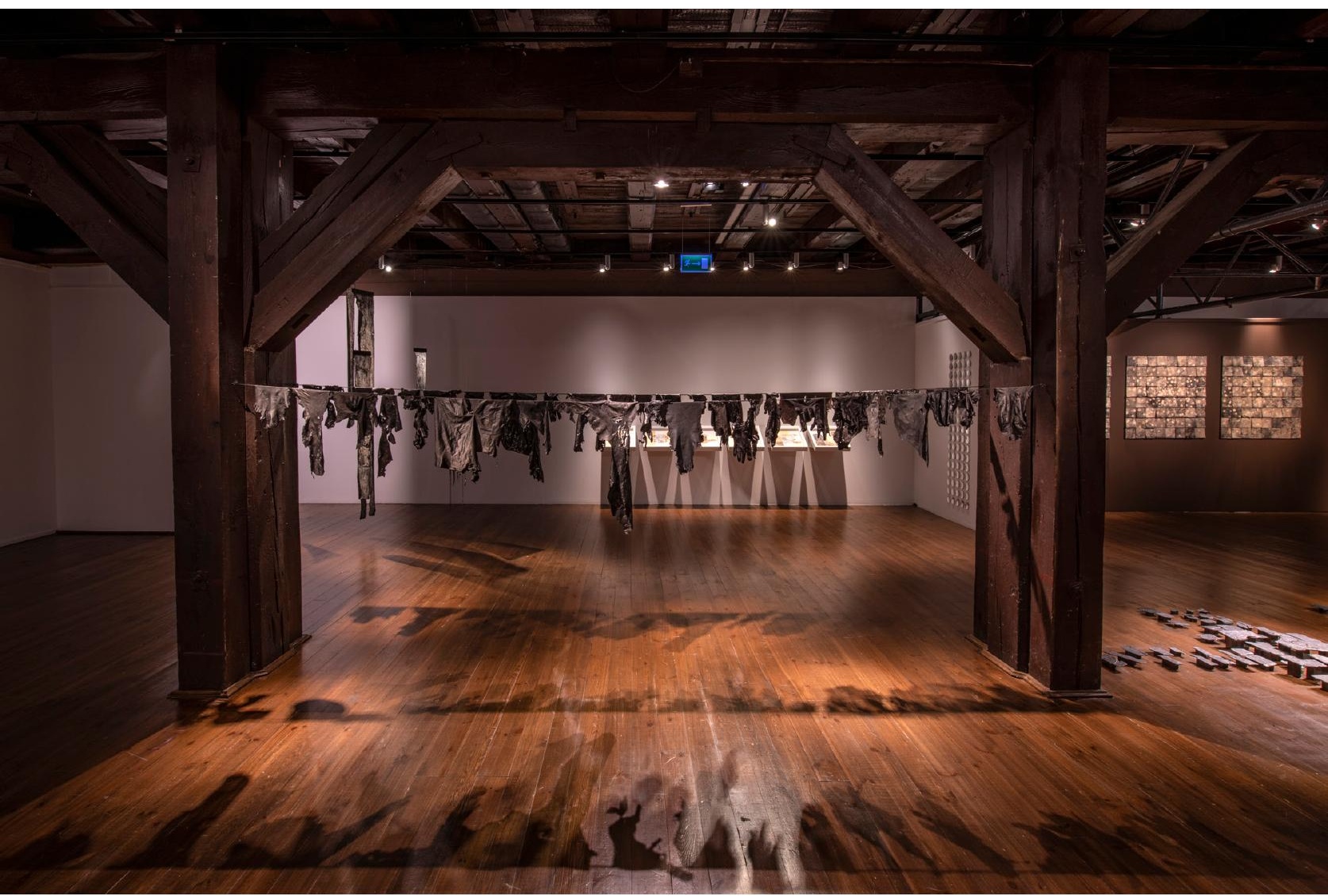

Fig.3.21. Priscilla Romero, Seǵunda piel, montaje de matrices latexgráficas del cuerpo humano, 2019 
Seǵunda Piel (2019) (Fig.3.21), es un conjunto escultórico en el exponemos al público una parte representativa de nuestras matrices latexgráficas, muchas de las cuales nos han acompañado desde hace más de una década, cuando iniciamos con la técnica en el máster. La idea de esta obra gira en torno a un concepto simple, el de traer a la sala de la galería un trozo de nuestro taller, en donde estos pellejos de látex se exhiben como si fuera ropa tendida o trozos de cuero en una talabartería. Son la materia prima, a través de la cual hemos impreso múltiples huellas, tanto sobre papel como en otras superficies tridimensionales como la escayola. Esta pieza es, sin duda, la matriz de nuestra producción, nuestro acerbo más preciado, ya que, algunas de las personas que donaron este material, hoy ya no se encuentran con nosotros, y otros tantos fragmentos encarnan recuerdos de encuentros efímeros con desconocidos, pero muy representativos.

Todos y cada uno de estos objetos representan relatos de vida de la persona que ha servido de matriz primigenia, por ejemplo, cicatrices del cuerpo a raíz de amputaciones, cirugías o accidentes, así como las simples, pero no menos importantes, marcas del envejecimiento. Cada quien, antes de registrar su huella con el látex, ha meditado qué parte del cuerpo le interesa detener en el tiempo, para preservar y reproducir su memoria gráfica. Este simple acto ya es, en sí, una toma de conciencia de su corporalidad, y fue escogido por razones específicas, las mismas que quedaran en el anonimato, así como su identidad. Al igual que el Archivo digital, ésta es una pieza que se inició hace ya un tiempo, pero mantenemos el propósito de seguir ampliando su colección a lo largo de nuestra carrera, conservando y transmutando en un material expresivo, la memoria de la huella de la piel de las personas con las que nos vamos encontrando, y que voluntariamente pasan a ser parte del rito técnico. Segunda Piel, también resguarda las matrices de nuestro cuerpo, las cuales se mezclan con las de los otros intencionalmente, de manera que pasan a ser unas más dentro del colectivo, sin jerarquía.

El color negro de estas matrices se debe a que han sido impresas en su totalidad, y la tinta queda impregnada en su superficie porosa, tal cual si 
fuera la piel humana. La tinta, en vez de alterar su conservación, la ayuda, ya que la mantiene humectada y evita que se reseque. El látex líquido natural es un material orgánico, y se comporta muy similar a la piel. Estas matrices no se pueden limpiar con disolventes, ya que las degradaría como sucede con los guantes de látex y el petróleo, al exponerse por un tiempo. Si fuera necesario, como ha ocurrido en varias ocasiones, se lavan con agua y jabón, y así se extrae el exceso de pigmento para seguir registrando con calidad la huella. Tal y como se observa en las fotografías, hay matrices positivas y negativas, es decir, algunas provienen del método directo en el que el látex entra en contacto con la piel (negativas) y otras vienen de moldes corporales de alginato, escayola o silicona; estas son las que resultan ser una réplica del cuerpo y su apariencia (positiva) (Figs.3.22 y 3.23).

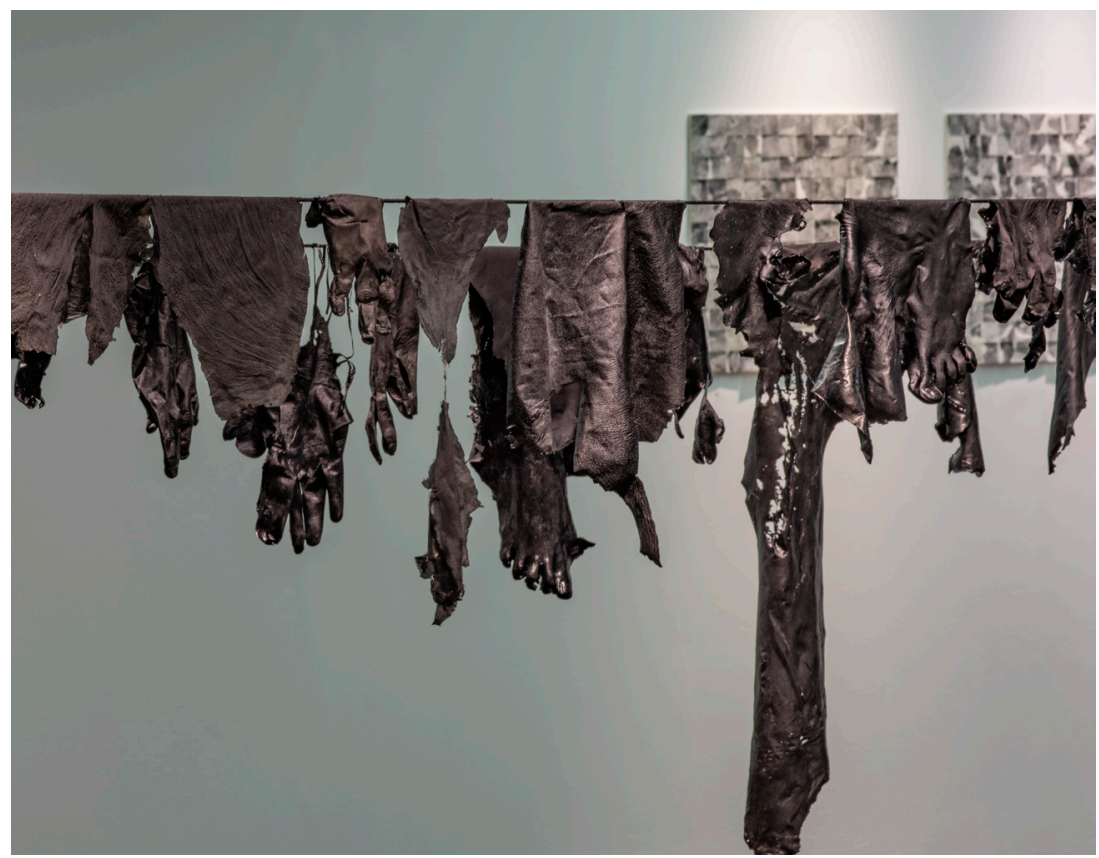

Fig.3.22. Detalle de Seǵnda piel, donde se observa la variedad de fragmentos corporales y sus diferentes texturas y matices. 
Fig.3.23. Detalle de una matriz latexgráfica, en positivo, de un pie, que previamente se registró en alginato. Tal y como se observa, esta matriz está expandida y rasgada adrede durante el proceso de ejecución, para desdoblar la forma convencional del cuerpo y jugar con las posibilidades formales de un grabado en hueco.

\subsubsection{INDEX /INDICIOS}

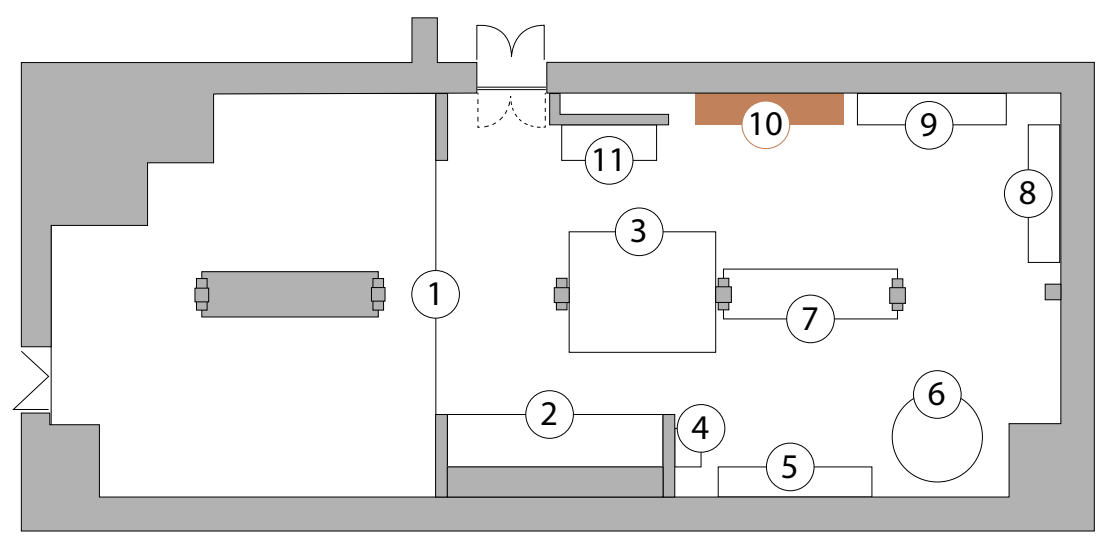

Fig.3.24. Vista de planta de la galería del MOB. Con el número 10, ubicamos el proyecto Indicios en el plano, para que se aprecie su dimensión, composición y emplazamiento. Cada estampa es de $20 \times 20 \mathrm{~cm}$. 

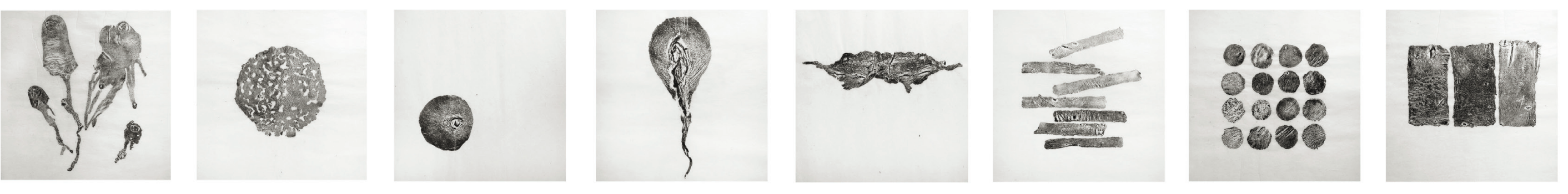

00
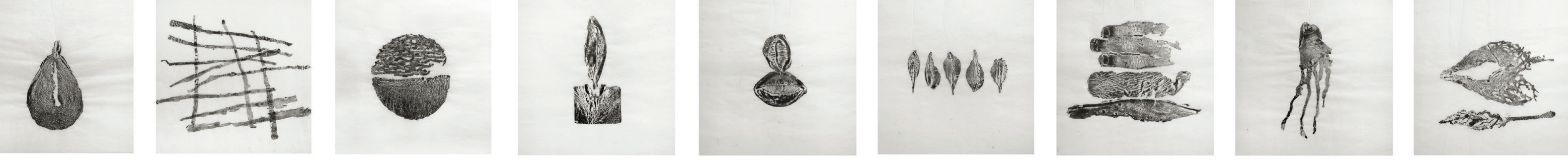

Fig. 3.25. Priscilla Romero, Indicios, impresión latexgráfica sobre papel gampi, 2013-2019. 
Indicios (Fig. 3.25) es sin duda una serie de trabajos diferenciales dentro del corpus de obra de nuestra investigación, ya que precede a todos los anteriores y se encuentra abierta, es decir, se han ido incorporando y quitando piezas desde que se inició en el 2013 hasta la fecha. Hay una clara influencia del texto de los 58 indicios sobre el cuerpo, de Nancy (2016), a través del carácter simbólico en el que nos acercamos al cuerpo, en tanto que colección de partes significantes, donde extraemos las áreas que le interesan, a manera de signos dentro de una composición gramatical. En la construcción de las matrices latexgráficas de este conjunto, hay partes del cuerpo que pierden por completo su referencia inicial y remiten a otras formas orgánicas. ¿Son indicios, pero de qué? A esta respuesta responde el público, atónito, cuando cae en cuenta que lo que creyeron era una huella de una flor resultó ser la vulva, o lo que aparenta ser una esponja marina, es la transición de las texturas del empeine y la planta del pie. Así, indicios es un juego lúdico que apuesta por desafiar la percepción de la realidad y las representaciones simbólicas que -convencionalmenteasociamos al cuerpo y su imagen. 


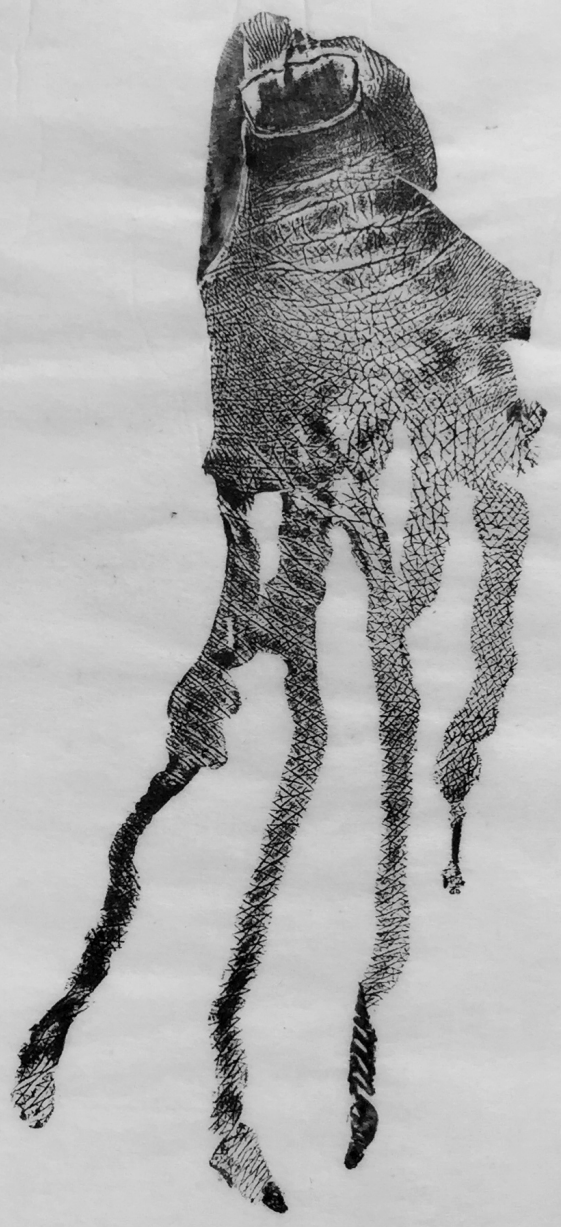

Fig.3.26. Detalle de Indicios, donde se aprecian los "chorretes" que deja el látex líquido al realizar la matriz latexgráfica de manera directa. Este recurso del proceso le agrega a la imagen una dimensión lúdica y dinámica, que el pequeño dedo se convierte en un personaje. 

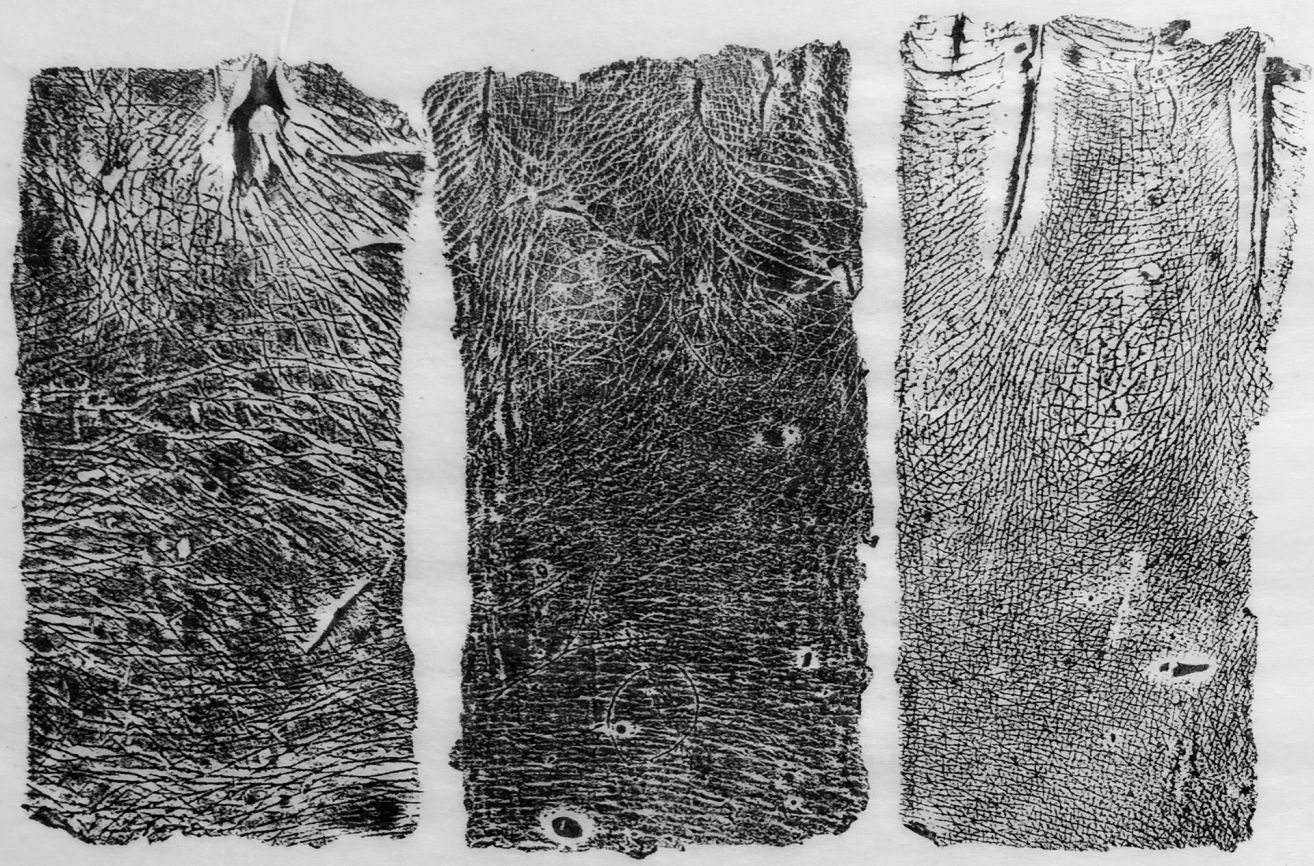

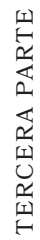

Fig. 3.27. Detalle de Indicios, donde se observa el paso del tiempo, documentado en tres fragmentos de piel de la misma parte de la mano, de tres personas con treinta años de diferencia entre cada una. De izquierda a derecha, se ordena de mayor a menor edad. 


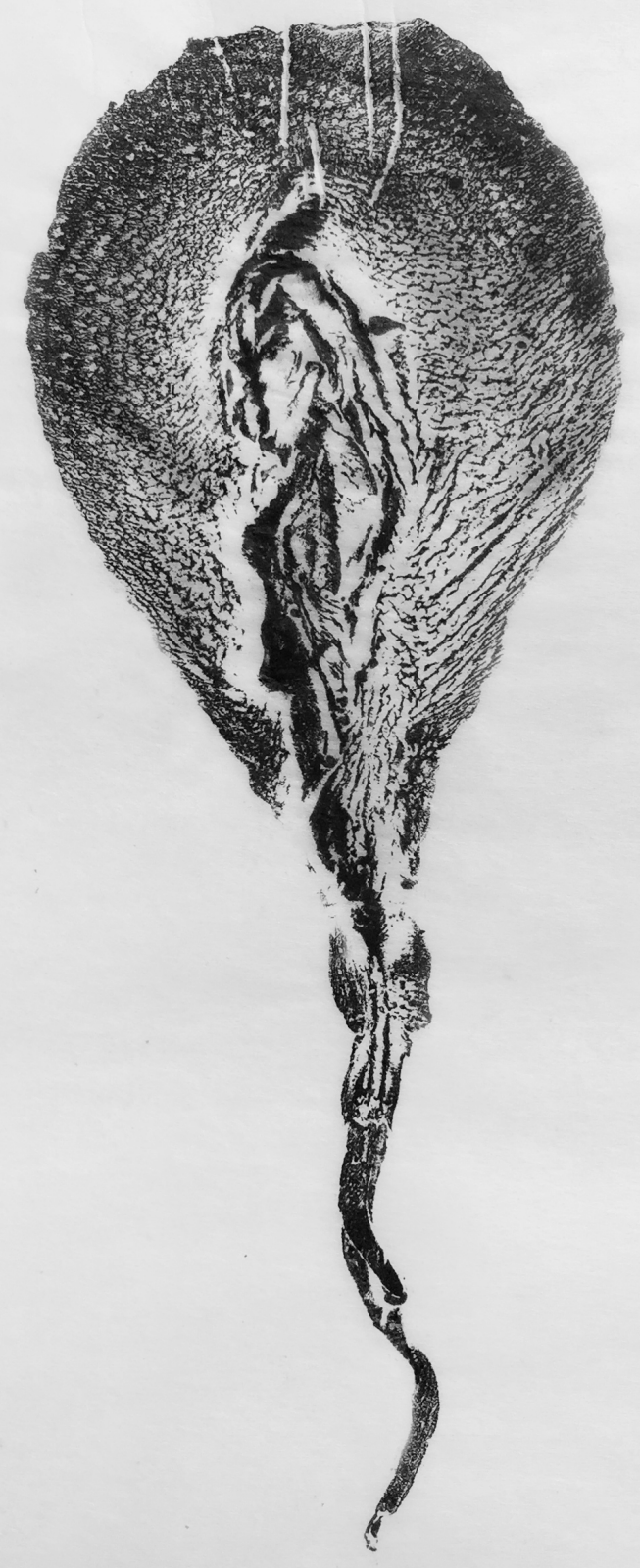

Fig. 3.28. Detalle de Indicios, donde se observa la forma en positivo de una vagina. Esta silueta no ha sido recortada, sino que se vierte el látex sobre el área del molde que a la artista le interesa destacar, dejando que el líquido fluya por el volumen y este es el resultado. 


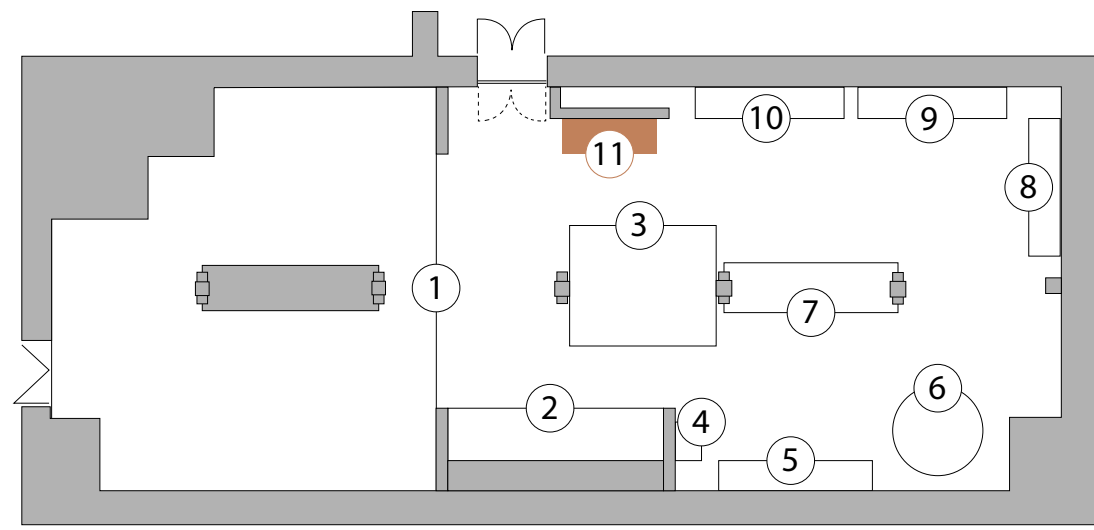

Fig. 3.29. Vista de planta de la galería del MOB. Con el número 11, ubicamos el proyecto El rastro de Midas en el plano, para que se aprecie su dimensión y emplazamiento. Dada la importancia de esta obra y sus características diferenciales, se ubica en una pared sólo para ella.

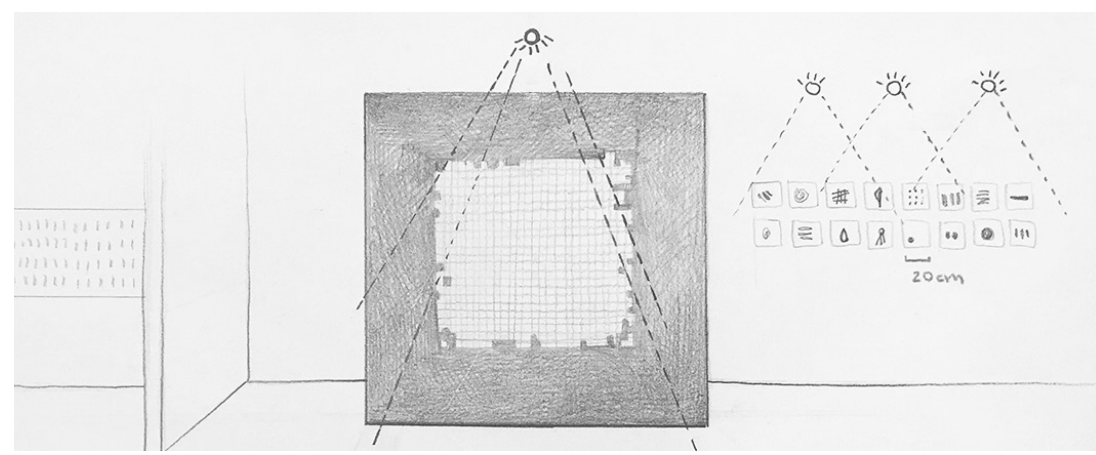

Fig. 3.30. Boceto para montaje de El rastro de Midas. Se plantea utilizar el mismo color del cielo raso para que la pared de fondo se mimetice con el espacio y sobresalgan los fragmentos dorados. Esta pieza tiene un formato irregular, por lo que hay partes del fondo que se dejan ver a través de la misma. La obra tiene $1 \mathrm{~m}^{2}$, y cada fragmento mide $4 \times 4 \mathrm{~cm}$. 
Finalmente, terminamos este breve recorrido por la muestra con la obra que nos trajo hasta aquí. Estamos hablando de la pieza ganadora del premio Leon Wyczólkowski, en la Trienal Internacional de Grabado de Cracovia, la cual titulamos El rastro de Midas (2018 (Figs. 3.31 y 3.32), en referencia al mito griego del Rey Midas, que todo cuanto tocaba se convertía en oro, como regalo concedido por los dioses. En esta imagen, nos basamos en dicho relato, pero vamos un paso más allá, ya que -según la historia- lo que en principio fue un don especial para el codicioso rey, se convirtió en un castigo, ya que llegó el momento en que todo lo que le rodeaba brillaba, pero era inerte como el preciado metal en que se transformaba. Este relato cuenta que, Midas, al punto de la locura, implora que le quiten este poder, porque pudo ver que lo más preciado en la vida, no era la riqueza del oro, sino el agua, la comida y sus seres queridos.

Aquí partimos de este relato mitológico para metaforizar en torno a nuestra sociedad y la manera en que el poder ciega a las personas, quienes no miden las consecuencias de sus actos, más allá de su propio bienestar, olvidando que vivimos en comunidad y que el ser humano es parte de la naturaleza que provee su bienestar. Técnicamente, para esta obra tomamos la mano como símbolo de la creación humana, y registramos cuatro manos de hombres de distintas edades, para acentuar el paso del tiempo mediante la huella de sus pieles. Así, una vez elaboradas las matrices latexgráficas, se imprimen sobre papel gampi y se fragmenta su forma referencial, para construir un mosaico de pequeños trozos de rastros dactilares, dentro de los que se distinguen parte de los dedos, a manera de indicios corporales.

Cada pequeño trozo de 4 x 4 centímetros (más de 400 en total), tiene tras de sí otro papel de iguales dimensiones, dorado mediante el chinecollé. De modo que, con el vaivén del gampi fijado a la pared con alfileres, cada fragmento toca el aparente oro, que tanto se desea como símbolo del poder. Pero a costa de este acto aprensivo, las manos quedan destrozadas en restos apenas reconocibles. Una metáfora simple, que se hilvana desde la composición y los elementos formales, para dar sentido poético a esta 
particular visión del poder y la condición humana. Para su montaje se tomó en consideración el hecho de que la imagen tiene una composición abierta en la que el fondo se deja ver en varios cuadros, por lo que, para efectos de la presente muestra, se pintó la pared del mismo color marrón que Tesoro viviente, obra que se encuentra justo enfrente, al otro lado de la sala. En ambos casos, el contraste cálido del pan de oro juega muy bien con el marrón que se camufla con las estructuras de madera de la galería.

Hoy, esta pieza es parte de la prestigiosa colección de obras ganadoras de la MTG, y es la primera vez que una artista latinoamericana obtiene este galardón en los más de 50 años de trayectoria de este evento. Para nosotros, este hecho, nos llena de orgullo, pero también de una inmensa responsabilidad, ya que es un aliciente para seguir produciendo obra artística con la calidad de los estándares internacionales en los que participamos. Una muestra de ello son las nuevas incursiones acometidas en nuestros más recientes trabajos, que veremos a continuación.

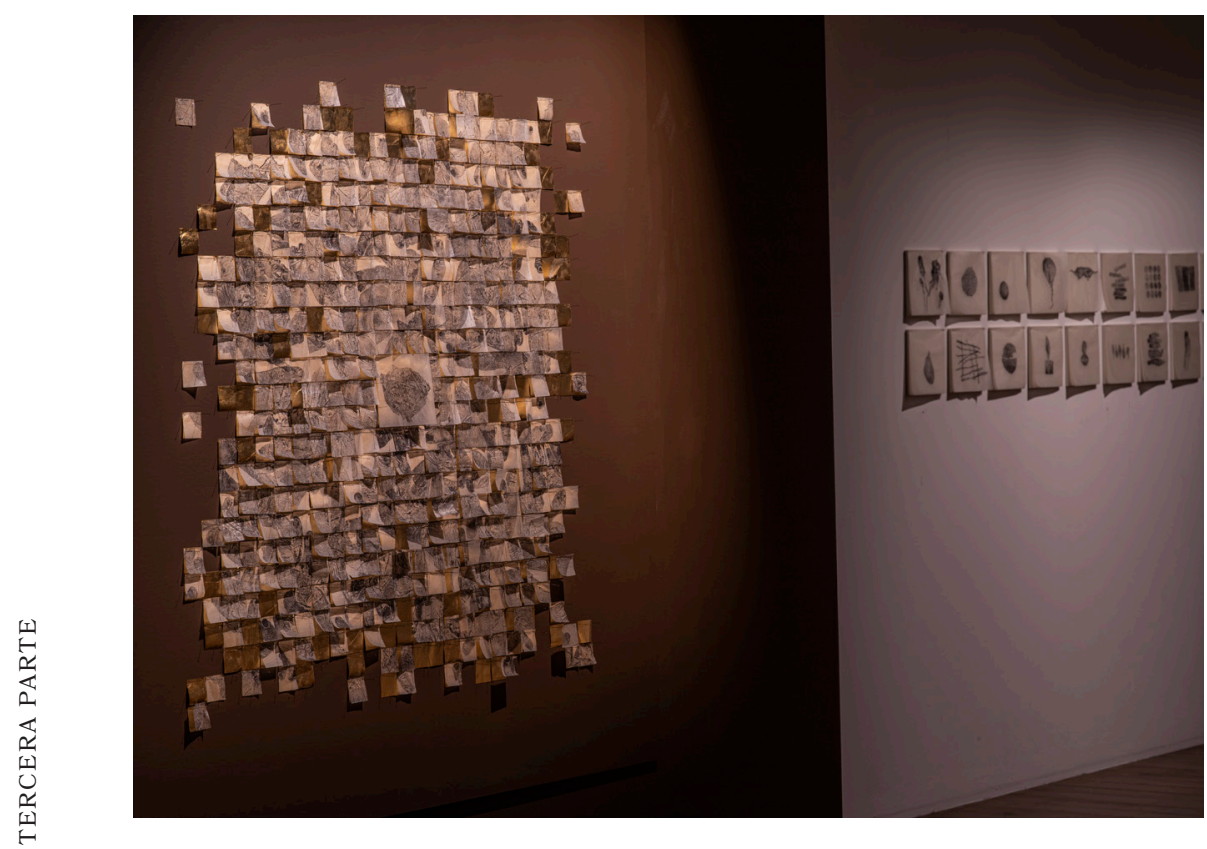

Fig.3.31. Vista de El rastro de Midas en el marco de la exposición. 


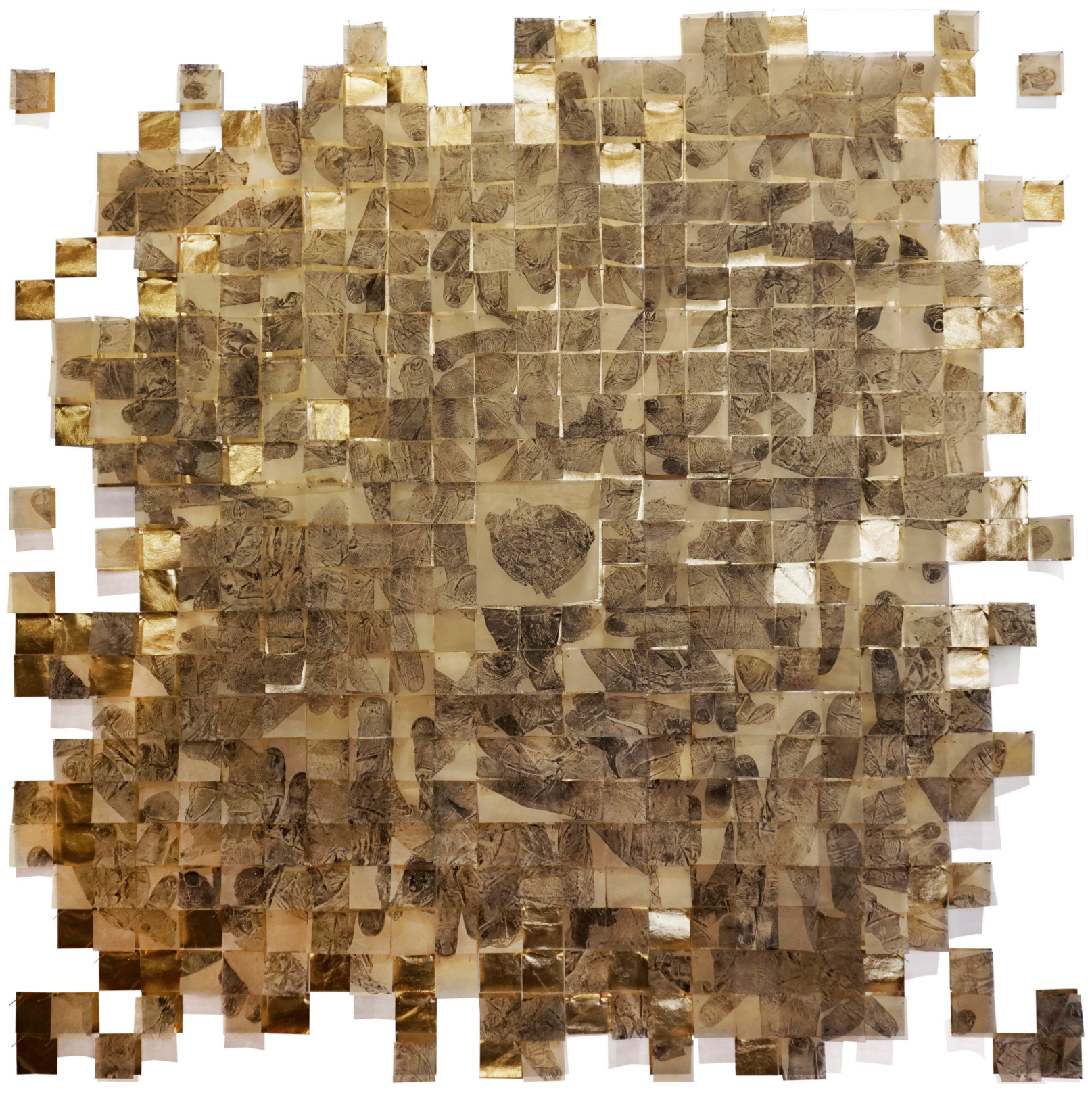

Fig. 3.32. Priscilla Romero, El rastro de Midas, latexgrafía sobre papel gampi, y chine-collé con pan de oro. 


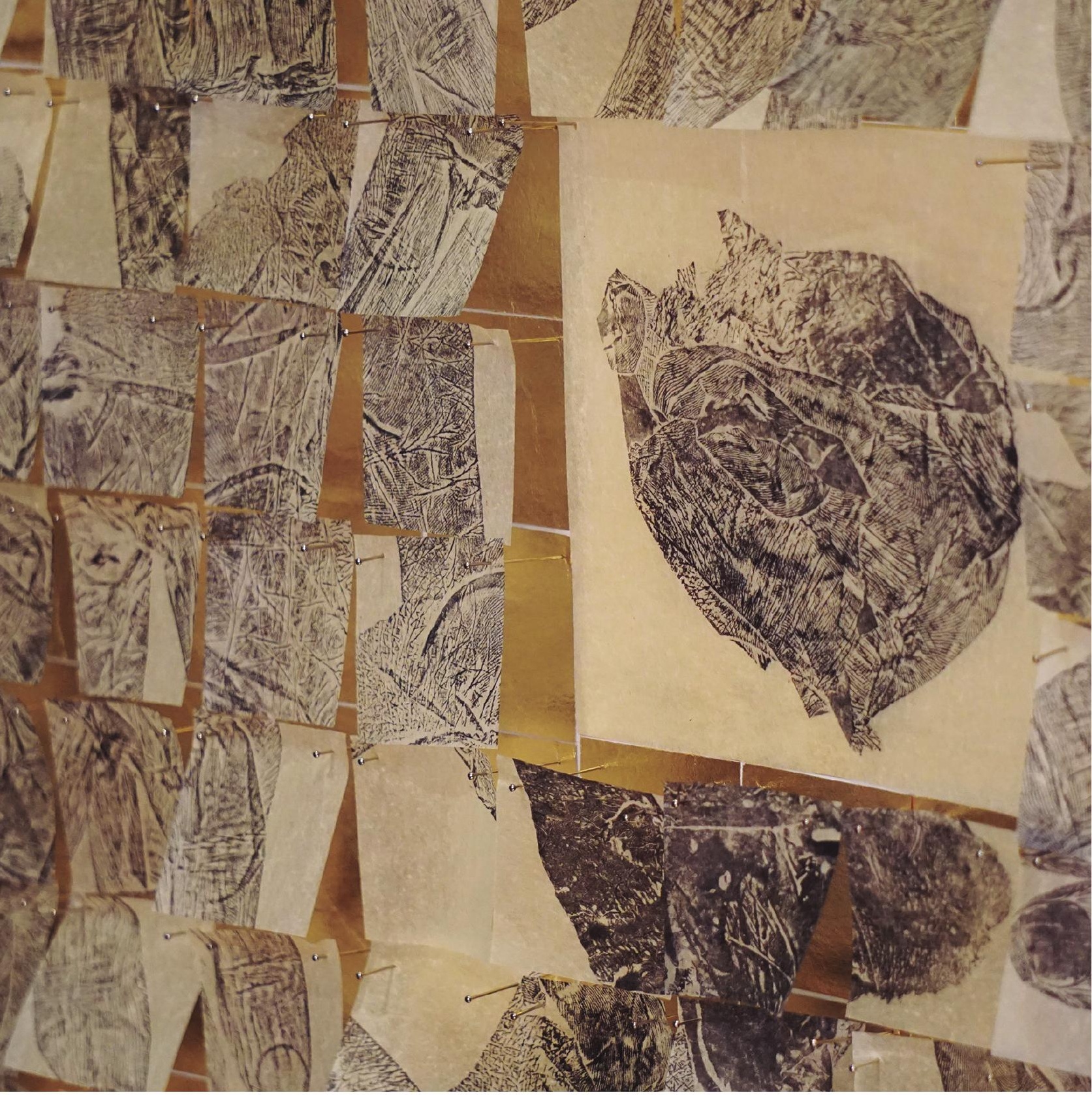

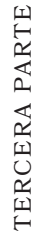

Fig. 3.33. Detalle de montaje y doble capa de papel. 


\subsection{NUEVOS TERRITORIOS DE LA GRÁFICA}

Al concluir un proceso tan enriquecedor y demandante como una muestra individual, siempre quedan ideas que no se llegan a concretar, pero que se maduran con la distancia. Este es el caso de los siguientes proyectos, realizados en el presente año. Inmersos en la pandemia, y lo ello implica, en términos de la redefinición de las fronteras del cuerpo, el valor del tacto y la memoria. Desde Costa Rica, planteamos nuevos recorridos gráficos por circunstancias que nos impactaron personalmente, en un tono más íntimo encarnamos una realidad colectiva, como la perdida de un ser querido, sin poder cerrar el duelo con los ritos funerarios. En este contexto, la memoria y la resiliencia, parecen cobrar un papel relevante en nuestras imágenes más recientes, en las que incorporamos procedimientos y componentes técnico conceptuales como el chine-collé y la filosofía oriental del Kintsugí -antes explorados- para hablar de las cicatrices de la vida, y, por otra parte, incursionamos, por vez primera, en la impresión digital y la imagen fotográfica como obra, sin dejar de lado conceptos básicos como la identidad y la huella, sólo que esta vez, desde la resignificación de lo virtual, en un contexto en que la no presencialidad se ha vuelto nuestra nueva normalidad.

\subsubsection{FOLD / /EL PLIEGUE /}

El Pliegue I (Fig.3.34), es parte de una serie que se inició en el presente año, inspirada en la concepción filosófica planteada por Deleuze (1989) en El pliegue. Leibniz o el barroco, y en la filosofía oriental del Kintsuǵi. En nuestra imagen, las curvas del papel gampi nos recuerdan los pliegues de la piel, en cuya delicada superficie no existe una jerarquía de texturas, sino un continuum hasta el infinito, que no hace más que expandirse y transformarse en sus giros, a través de cada movimiento y con cada arruga. Bajo esta concepción, el cuerpo no tiene un principio ni un fin, ni un orden establecido para leerlo y clasificarlo, sino que es un corpus que fluye, se contrae, retrae y repliega en sí mismo, tal y como lo hacemos con las matrices latexgráficas, gracias a su naturaleza elástica, o al plegar y doblar las improntas, dándole continuidad a las huellas epidérmicas impresas en los diferentes fragmentos, a través del movimiento del papel. 

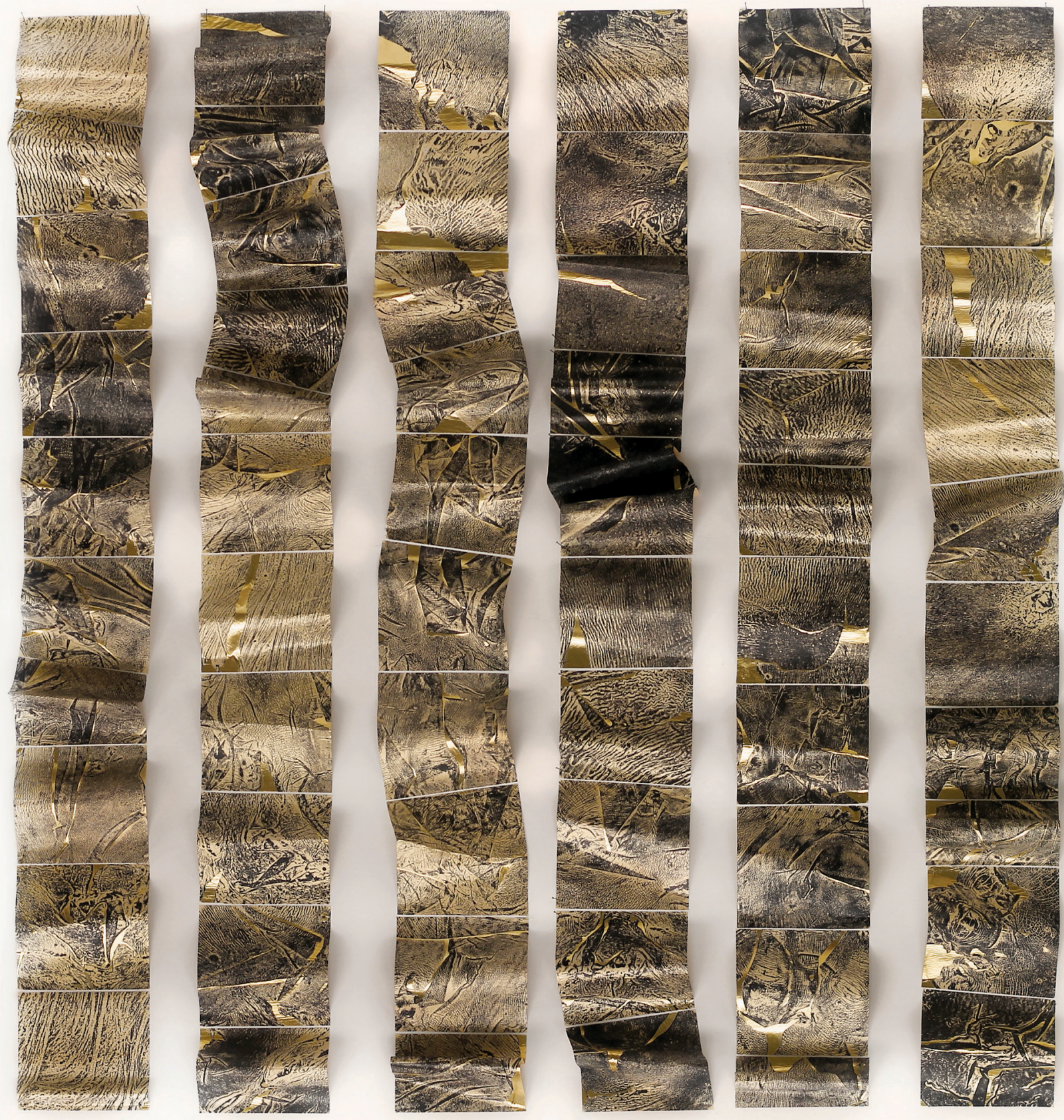

Fig. 3.34. Priscilla Romero, El plieǵue I, latexgrafía sobre papel gampi y chine-collé con pan de oro, 2021 
Sin embargo, este fluir orgánico se debate dentro de una estructura reticular y modular, de la cual, cada cuadrado de papel intenta salir o incorporarse. Este gesto compositivo plantea situar al espectador en un juego ambiguo, en el que, metafóricamente, el módulo puede ser visto como un cuerpo que se encarna al tejido social, adaptando su forma, amoldándose a una estructura o tratando de salir de ella, pero llevando consigo sus grietas y cicatrices. Son precisamente estas últimas cualidades, las que se realzan en la filosofía oriental del Kintsuǵi, la cual, aplicada a nuestro discurso, les da un valor a las pequeñas imperfecciones de la piel, sus pliegues y marcas, las mismas que técnicamente calamos con cúter de la imagen impresa, vaciando estos espacios para que sobresalga el pan de oro, adherido a la superficie mediante el método del chine-collé. Todo el conjunto es un collage de capas ultradelgadas que no afectan la movilidad de las curvas y los pliegues, y más bien les confieren más firmeza para manipularlas (fig.3.35).

Así, cada fragmento se une a través del continuo pliegue y las cicatrices compartidas, que, en vez de ocultar, realzamos en oro, para recordar que somos las huellas que la vida ha dejado impresas en nuestra piel. Una historia gráfica, que une nuestros intereses particulares por las nociones del cuerpo que rompen con la idealización, para resignificar aquellos conceptos que nos rigen hegemónicamente, como la belleza. De esta forma, la cicatriz de una rodilla, la piel corrugada por el tiempo o las grietas de un codo, pueden brillar por si mismos, y coexistir en un espacio abstracto con dimensión estética. Una vez más, la poética que emana del material es crucial, así como la articulación del lenguaje visual dentro del proceso técnico, para construir una imagen metafórica del cuerpo de estas características. 


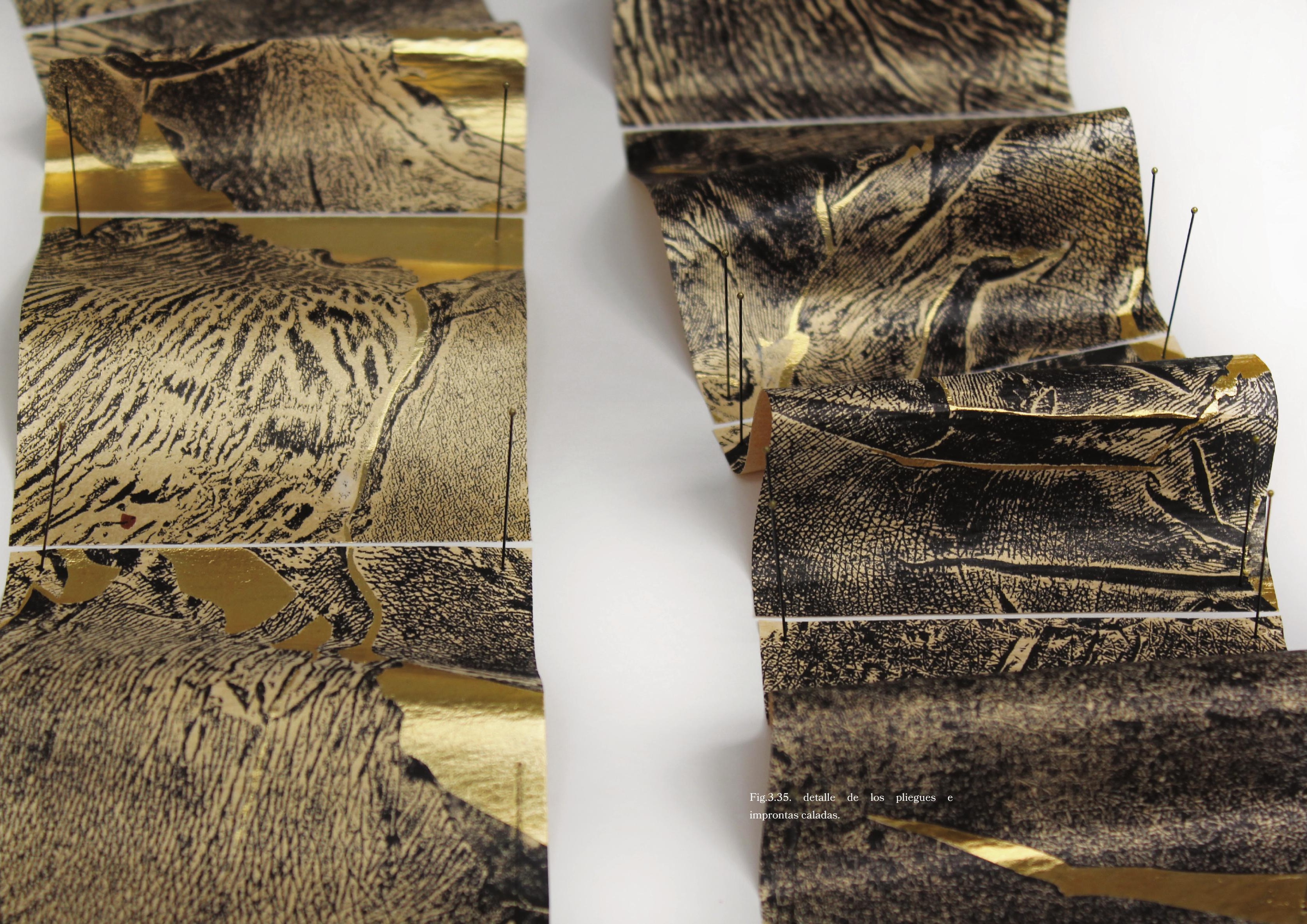




\subsubsection{IMAGO / IMAGO}

Como es sabido, el término imagen viene del concepto de imago que utilizaban los romanos para las máscaras mortuorias. Partiendo de esta noción, Didi-Huberman (2015) nos plantea la dimensión de la imagen matriz, (que revisamos en el apartado sobre El sentido de las imágenes), dado que su importancia recae en el valor de la técnica y el tiempo, ya que requiere que exista un contacto por adherencia entre el cuerpo y la escayola. De modo que, tras este encuentro, la imagen que se transfiere en la máscara, permanecerá viva en la memoria de la materia, aunque el cuerpo del que proviene, no lo haga. Una noción que hemos abordado ampliamente en el presente trabajo, gracias a la implementación de la latexgrafía.

Así, mucho antes que existiera la dactiloscopia, el imago fue una forma para registrar genealógicamente la identidad de alguien, guardando un archivo material de su huella corporal como prueba de su existencia y muerte. Sin embargo, hoy día, se conjugan diferentes métodos para documentar nuestra identidad, como, por ejemplo: la fotografía, la huella dactilar y los códigos de acceso rápido, conocidos por sus siglas en inglés como QR, en los que se puede almacenar cualquier tipo de información, que previamente esté respaldada en la memoria de la nube. Tomando en cuenta estos factores, conjugamos -en lo que es nuestro trabajo más intimo y personal- los conceptos antes mencionados, en un homenaje póstumo a nuestra abuela, quien, en múltiples ocasiones fungió de matriz primigenia para esta investigación, dejando un amplio legado de moldes, matrices y huellas latexgráficas en nuestro acervo. Ahora, les invitamos a tomar sus móviles y escanear el siguiente código QR, para develar la imagen que en él se archiva (fig.3.36). 

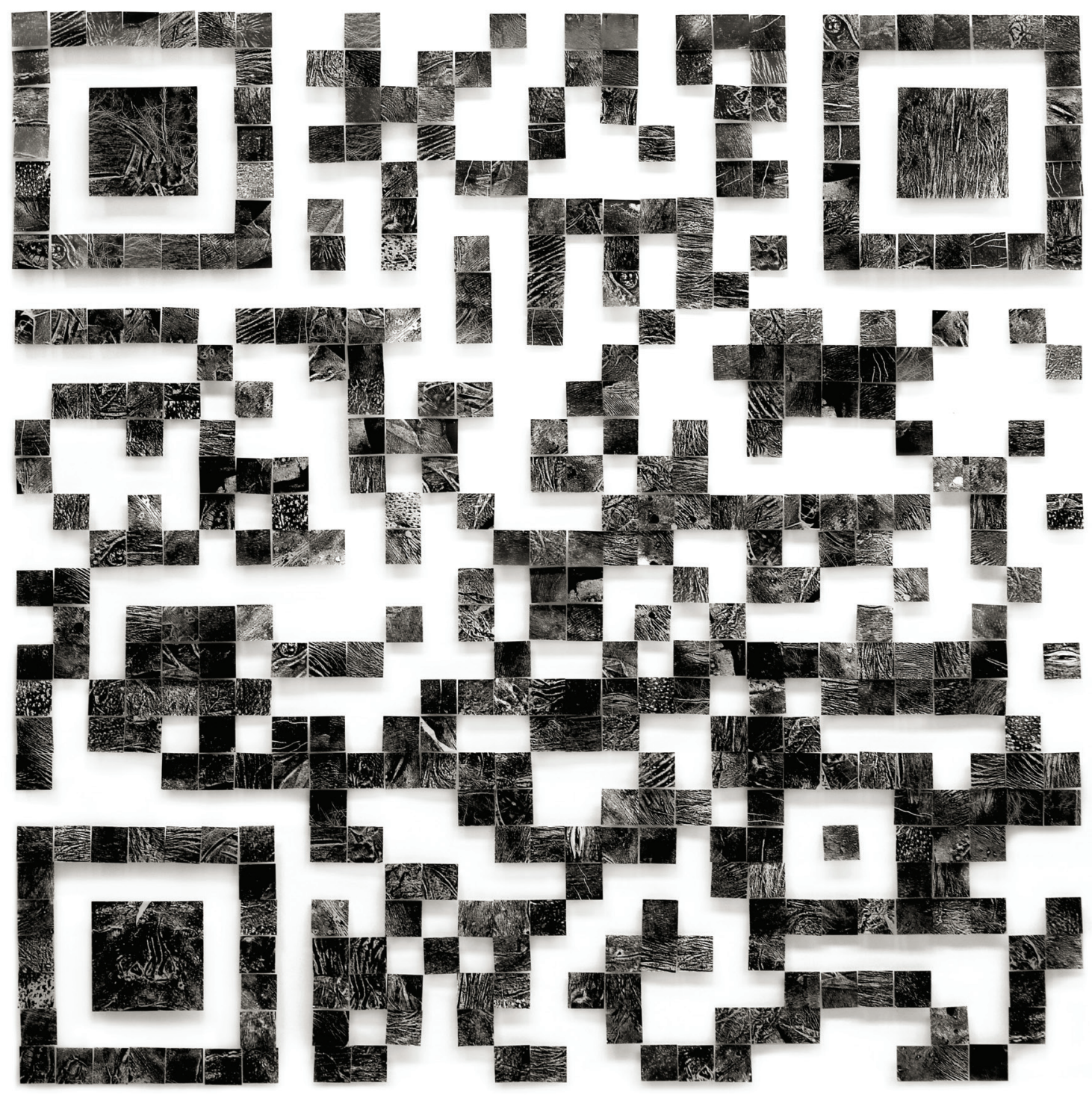

아요

Fig.3.36. Priscilla Romero, Imaǵo, latexgrafía e impresión laser sobre polímero litográfico, $1 \times 1 \mathrm{~m}, 2021$ 
Como pueden ver, la imagen es una fotografía de una máscara en positivo de escayola, pero no cualquier máscara, esta es el imago que habíamos registrado de nuestra abuela, la última vez que estuvimos juntas. Después del fallecimiento de este ser querido, consideramos propicio realizar una obra póstuma, en la que se involucrara tanto el molde de escayola como las matrices y huellas latexgráficas que provenían de este objeto y de la piel de la persona fallecida, en un solo proyecto. Para llevarlo a cabo, primero se toma la fotografía del molde, luego se sube a la web y posteriormente se crea el link con el que se genera el código QR. Una vez que contamos con éste, procedemos a imprimir digitalmente las huellas latexgráficas que teníamos archivadas, provenientes de las diferentes partes del cuerpo de la abuela -incluyendo la máscara de escayola -. Cada pequeño fragmento de $3 \times 3 \mathrm{~cm}$ es una impronta epidérmica, de una persona que ya no está físicamente con nosotros, pero que, gracias a este procedimiento técnico, su memoria sigue y seguirá viva, tanto en la nube inmaterial de la virtualidad, como en el soporte tangible del imago, y cómo no, en nuestra imaginación. Por consiguiente, este conjunto de obras, provienen de una matriz primigenia que cobra presencia y sentido en su ausencia.

Técnicamente fue todo un reto, ya que, con sólo un módulo que quedara fuera de lugar o no tuviera el contraste requerido, el código QR, conformado por cientos fragmentos de huellas corporales, no se podría leer; así que -cómo nunca antes $\urcorner$, la composición estaba predeterminada y el montaje debería de ser absolutamente preciso, no se aceptaba un fallo en su configuración. Dadas estas circunstancias y las características del discurso, creímos que las láminas para litografía digital (conocidas como pronto plates, por sus siglas en inglés), serían un excelente soporte, ya que son un polímero opaco, resistente, firme y translucido, como el gampi, por ende, sus características formales resultaron idóneas, para imprimir las huellas latexgráficas del cuerpo, sin alterar su registro ni escala real. Lo demás: el corte, composición y montaje, se realizaron de la manera habitual, es decir, manualmente y con alfileres, para que la imagen no fuera plana, sino que tuviera distintas alturas (Fig. 3.37). 


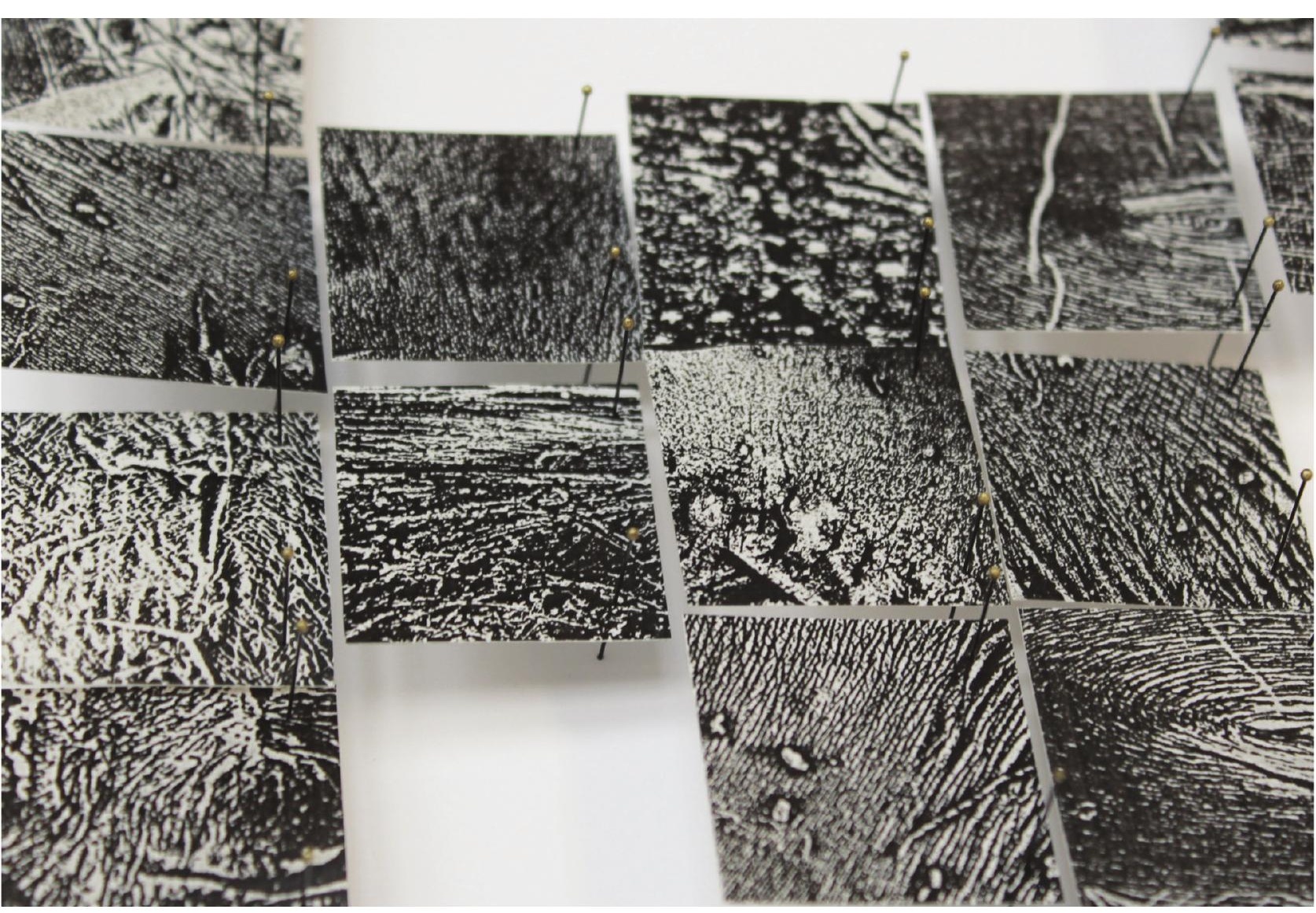

Fig.3.37. Detalle de los fragmentos que conforman la figura del código QR de Imaǵo. Cada una de estas improntas tienen escala natural y provienen de huellas latexgráficas de la piel de la abuela de la artista. 
La memoria de la piel, es el recuerdo latente del contacto entre nosotros y el mundo. En ella se registra el rastro de la vida, con sus altibajos, pliegues y cicatrices. Cada huella es única e irrepetible, como lo son también los códigos QR, ambos, codifican en sus líneas los fragmentos de realidad. En la primera, la experiencia es directa, y en la segunda, la realidad está mediada por una pantalla. Todo este cúmulo de líneas y puntos son un enorme documento, una imagen que codifica la identidad de cada quién, sin que apenas esa persona se entere. En nuestro cuerpo, no hay espacio ni poro de nuestra piel que no sea una superficie emisora y receptora de sensaciones y estímulos, que nos permiten percibir el mundo. En esta investigación no hacemos otra cosa más que documentar ese texto, modularlo en diferentes metáforas, que revistan, lo que ya el tiempo ha hecho por nosotros: grabar los relatos de una vida, en un tejido que envuelve desde adentro, el ser que percibimos afuera.

Cuando sabemos que no volveremos a tocar a un ser querido, quedan en nuestra memoria las sensaciones más efímeras, como su olor, el tono de su voz, el sonido que hacía al caminar o el roce de su piel. Todos estos aspectos quedan grabados en nuestra memoria y, con el tiempo, vamos viendo como se desvanecen sin que podamos hacer más que dejarlos partir, previo a que su frescura se convierta en algo que nunca fue. Sin embargo, gracias a la latexgrafía, tuvimos el honor de registrar a cientos de personas, muchas de ellas quizá ya no existan corporalmente, pero la replica de su piel sí perdura, y mediante estas matrices latexgráficas podemos volver a sentirlos a través del tacto, ver cómo cada pequeño gesto de su comportamiento dejó tras de sí una marca gráfica, que atestigua su historia de vida, en el anonimato profundo que resguarda la superficie de la piel.

Fig.3.38. Fotografía digital de la máscara del rostro de la abuela (q.e.p.d.) de la artista. Esta imagen es la que genera el código QR que da forma a la obra Imaǵo, 2021. A partir de este positivo, se han extraído varias matrices latexgráficas utilizadas durante el proceso de impresión. 


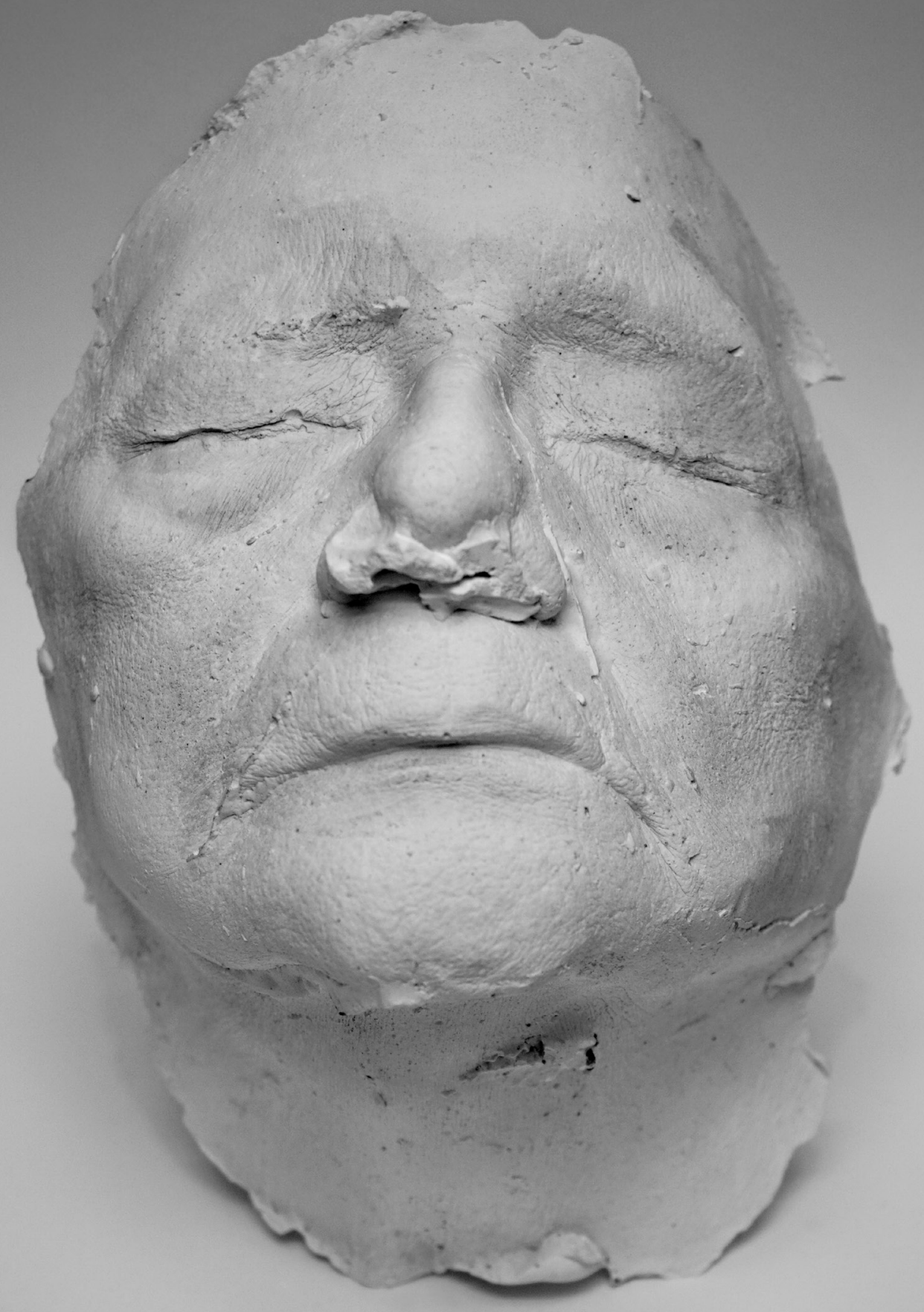




\section{CONCLUSIONES}

A razón de los tres partes principales, hemos identificado las siguientes conclusiones generales de la investigación:

Como primera conclusión destacaríamos que planteamos esta tesis como una alternativa metodológica a los enfoques positivistas, para posicionar la investigación artística como un ámbito del conocimiento válido, necesario y legítimo, dentro del contexto académico de cara a la sociedad. Así, esta investigación se formula desde la vertiente del Arte como Ciencia Proyectual que plantea Mínguez García (2014). A la luz de esta perspectiva y en congruencia con la experiencia del presente estudio, podemos argumentar que nuestra producción artística no se reduce a la ejecución del objeto estético, sino que implica un ejercicio de reflexión crítica, que recae en la construcción de un andamiaje teórico interdisciplinar, que finalmente se concreta en forma de documento. En este texto, se sistematizan los procesos creativos desde su fundamentación conceptual y práctica, de forma continua e imbricada. De manera que hemos expandido el rol del artista productor como investigador, mas allá de la materialización de sus obras, para que se inserte en el contexto comunitario como gestor proyectual, mediante la extensión docente, incorporando al público como agente imprescindible de nuestro trabajo en todas las etapas.

En segundo luǵar, hemos demostrado la eficacia de la latexgrafía como medio inédito para la gráfica contemporánea, al conjugar los alcances técnicos con su dimensión discursiva, en torno a las prácticas artísticas expandidas en el campo interdisciplinar, para problematizar la dimensión simbólica de la piel como superficie de memoria. Para ello hemos estructurado el proceso, evaluando sus variables y estableciendo una serie de conceptos y resultados definitorios. A propósito, se entiende por latexgrafía, al proceso a través del cual se registra, transfiere y reproduce la huella de la piel y otras superficies, desdoblando el volumen de los cuerpos en matrices que se obtienen a partir de moldes de látex que 
emulan las características formales del tejido epidérmico. Gracias a este procedimiento técnico, la memoria gráfica de las superficies se expande y transmuta como una segunda piel, dejando su impronta en diversos materiales y soportes, tanto bidimensionales como tridimensionales.

La latexgrafía tiene tres componentes principales, los cuales corresponden a: la matriz primigenia, entendida como el cuerpo propio (superficie emisora primaria) sobre el cual el tiempo deja su huella grabada en la memoria de la piel. En segunda instancia, se encuentra la matriz latexgráfica, la cual es el molde de látex que registra la matriz primigenia, el mismo que al desprenderse - como una muda- trae consigo la impronta directa del cuerpo; y, por último, contamos con la huella latexgráfica, que es la impresión dejada por la matriz latexgráfica sobre una superficie o sustancia receptora. Dependiendo de las características de este último material, la huella puede ser una impronta táctil y/o visual. Todo este proceso se ha llevado a cabo mediante una exhaustiva investigación de medios y materiales no tóxicos que nos permiten trabajar, con y desde el cuerpo, sin atentar contra su integridad física, de modo que, a diferencia de muchas de las prácticas artísticas corporales, en nuestro caso, la piel se desdobla dejando al cuerpo intacto, y construyendo en el acto la materialización del contacto. A continuación, expondremos los resultados más relevantes de las variables técnicas que inciden en el proceso latexgráfico:

- Variables del molde: el molde es un componente utilizado en caso de que la matriz primigenia pueda resultar sensible al látex, y también como recurso formal para obtener improntas positivas del cuerpo emisor. Los materiales utilizados cumplen con los criterios establecidos para su utilización y podemos determinar tres sustancias óptimas, que, en orden de prioridad y rendimiento, son las siguientes: el alginato, la escayola y la silicona para prótesis corporales.

- Variables de la matriz: el material idóneo para realizar la matriz es el látex liquido natural, ya que sus características simulan el tejido epidérmico con gran fidelidad. Este producto cumple con creces los 
criterios técnicos y se pueden encontrar una gran variedad de fabricantes que procesan esta materia prima, sin embrago, la marca Holden 's latex nos ha parecido la de mejor calidad.

- Variables de la tinta y entintado: la tinta indeleble a base de agua para sellos de caucho marca Trodat y Coloris, ha sido la mejor opción para las impresiones sobre papel, ya que deja una huella nítida sin alterar la composición de la matriz y cumple con la norma DIN ISO 11798. Por su parte, el instrumento ideal para entintar son las esponjas conocidas como Beauty Blender, y la forma de hacerlo es manual.

- Variables del soporte e impresión: la huella latexgráfica se puede registrar tanto con tinta como en gofrado; todo depende de la naturaleza del material/soporte que se emplee como superficie receptora. En caso de los soportes bidimensionales, la impresión se realiza ejerciendo presión manual. Lo imprescindible, en este caso, es colocar la espuma viscoelástica, ya que este material permite que la fuerza sea uniforme y se transfiera hasta el último detalle en el papel, el cual, debe ser una superficie que no cause interferencia visual ni táctil, preferiblemente de un gramaje liviano y translúcido para que simule el tejido epidérmico, además de ser libre de ácido, características que nos confiere el papel gampi con creces.

Como tercera conclusión, consideramos que el carácter experimental del grabado es intrínseco a su naturaleza y condición histórica, habiéndose manifestado como un factor diferencial que no ha hecho más que acentuarse a partir de la segunda mitad del siglo pasado, gracias a dos antecedentes claves que abrieron la brecha por la que hoy muchos transitamos. Primeramente, el aporte del colectivo The New York Graphic Workshop, en la formulación del objeto del FANDSO, seguido de la incalculable contribución de Rosalind Krauss con respecto al giro expansivo de los campos y disciplinas artísticas, que confluyen en el concepto de la instalación. Desde entonces hasta ahora, la gráfica se ha extendido y expandido en el tiempo y el espacio, gracias a los andamiajes teórico conceptuales que muchos artistas -como nosotros- han tejido en 
la piel de sus procesos, para que el acto creador trascienda su dimensión meramente artesanal y reproductiva, y se abra a la reflexión crítica que analiza y revisa sus alcances cualitativamente. Esto no implica una renuncia a la tradición y su rigurosidad técnica, sino que la fortalece, al implementar su argumentación discursiva como parte de su práctica e investigación.

En nuestro estudio, podemos definir una serie de rasgos comunes a los discursos que hoy imperan en la gráfica contemporánea y las prácticas corporales, los cuales apelan a la capacidad para desarticular los nichos modernos y la noción del cuerpo, en donde este último, se convierte tanto en matriz como en soporte, para establecer un vínculo con el público en la acción performática de dejar huella. De manera que la piel en la latexgrafía es la superficie emisora y receptora, es la frontera que demarca los límites de la otredad, activando el rol pasivo del soporte y flexibilizando el carácter estático de la matriz. El segundo eje discursivo, apela al carácter mestizo que le da identidad a nuestra gráfica, donde conjugamos los componentes propios de la migración e hibridación de los discursos del arte contemporáneo, con la dimensión ritual que le damos al proceso latexgráfico, mediante el cual construimos una noción de comunidad. Así, la gráfica mestiza se identifica con una imagen del mundo inclusiva y democrática, que se resguarda en el anonimato de la huella de la piel.

En función de estos componentes discursivos, hemos identificado cinco aportes diferenciales que desde la latexgrafía hacemos al campo de la gráfica actual, los cuales son los siguientes:

- La transmutación de la matriz y la huella: este es un punto clave, ya que incide en el proceso en que se crea la matriz desde cero, en el acto del contacto entre el cuerpo y el material. El carácter reproductivo, inherente a la matriz, se expande más allá de la edición, ya que en nuestro caso puede engendrar otra matriz, dadas las características del látex y los moldes podemos continuar con esta cadena genealógica, desdoblando su huella en superficies de diversa índole, en las que nuestras matrices se 
comportan también como improntas. Por consiguiente, no nos interesa la estabilidad de una edición serial, sino la variedad de improntas que puedan generarse a partir de una misma matriz, imprimiendo así una huella distinta en cada tirada. Podemos considerar la latexgrafía como un proceso técnico que conjuga los límites entre estos dos componentes básicos del grabado, para extraer de estos pliegues el mayor provecho formal y conceptual, en una actividad creadora lúdica y experimental.

- La poética de la materia: El valor metafórico que emana de la materia en que está hecha la imagen artística tiene el potencial para captar la atención del público y trasladar consigo el significado que convencionalmente ha sido asociado a ella. De manera que, en nuestra investigación siempre partimos de las vertientes poéticas que la materia nos ofrece, en virtud de sus facultades técnicas, sin forzarlas, sino atendiendo cuidadosamente a sus cambios de estado y condicionantes físicos y químicos. En el caso del látex, este es un fluido orgánico que proviene de la corteza de un árbol, y se comporta y adapta a las superficies emisoras, registrando nítidamente su textura, y se desprende cual si fuera una muda de piel. Su elasticidad plástica es en sí misma una metáfora de la flexibilidad con la que asumimos los procesos creativos y la fluidez de la experiencia corporal.

- El proceso como rito: Al transmutar la piel en la matriz latexgráfica, se expande en ella la memoria gráfica que el tiempo ha grabado sobre nuestro cuerpo. Al expandir el taller al espacio público, hemos logrado que la experiencia íntima en torno a la percepción y experimentación de nuestro cuerpo propio, que motivó los inicios de latexgrafía, hoy se haya transformado en un lugar de encuentro y contacto colectivo, mediante el cual creamos vínculos comunitarios para promover inclusivamente la empatía a través del arte. En tanto, el cuerpo propio deviene en cuerpo social, en el que cada persona puede re-conocerse en la huella del otro, y así reconfigurar -entre todas- un imaginario colectivo de la corporalidad. En el rito latexgráfico lo que nos une es la diversidad de la condición humana. 
En consecuencia, nuestras improntas son la prueba material de esta experiencia, en otras palabras, la huella encarna y documenta la memoria in situ del proceso colaborativo. Cada quien accede voluntariamente al proceso en el que se autodespelleja en un trampantojo de su piel, donando su muda, a manera de ofrenda, la cual es para nosotros un fragmento de su identidad. Esta ofrenda simbólica es un acto de desprendimiento, y pasa a ser parte de un acervo anónimo de fragmentos corporales que pierden el vínculo individual para incorporarse al grupal. Cada trozo de piel de látex es para nosotros una prueba de estado, un testimonio de un presente que ya no volverá a ser, pero que, gracias a su condición material, podemos reproducir en ausencia del cuerpo que la engendró.

- De la expansión ǵráfica a la extensión socio comunitaria: cuando el proceso creativo se vincula al contexto en el que participamos, el trabajo de campo se convierte en un campo de trabajo. Un terreno fértil en donde el cuerpo propio se identifica con el del otro, en una relación en la que ambos se complementan. En nuestra investigación somos conscientes de la responsabilidad social que tiene la academia para promover la transformación cultural mediante la educación artística, dentro y fuera de las aulas. Por tanto, la latexgrafía ha abierto las fronteras del proceso creativo, para incorporar al público como co-autor imprescindible, ya que, sin su huella, no tendríamos objeto artístico, ni tampoco retribución crítica. Dos ingredientes fundamentales para la constitución del corpus de obra de esta tesis. Este factor, no sólo toma en cuenta a sus participantes como donadores de huellas, sino que también el espacio en el que se desarrollan, la memoria histórica del contexto en el que habitan y sus relatos, encarnados en la memoria de la piel, como archivo gráfico de la experiencia vivencial.

- Hacia un grabado de aprovechamiento: este concepto implica sacar el máximo rendimiento de las materias primas y los procesos, para obtener de ellos la mayor cantidad de variables técnicas y dimensiones poéticas. Pero también es una filosofía en torno a nuestra propia práctica artística, que, ante la escasez de medios y materiales de nuestro contexto, nos ha movido a desarrollar una técnica sostenible y sustentable, a través 
de procedimientos e instrumentos austeros, pero altamente eficaces, que están al alcance de muchos, tal y como hemos experimentado en nuestros múltiples talleres. El grabado de aprovechamiento también implica la conceptualización de las imágenes a partir de la versatilidad que nos da el medio. Así, hemos venido reutilizando nuestras matrices y moldes por más de una década, y éstos siempre arrojan imágenes nuevas y provocadoras.

Otro factor imperante del grabado de aprovechamiento, es la conceptualización de la imagen a partir del fragmento y el módulo, esto nos permite realizar obras monumentales en espacios de taller reducidos, y proyectar su composición in situ a través de una serie de diagramas, para reorganizar el orden de las piezas, a manera de rompecabezas. Este proceso, se puede llevar a cabo, gracias a las cualidades matéricas del papel gampi, ya que es extremadamente liviano y delgado, por ende, la forma de embalar y empaquetar, también tiene que ver con el aprovechamiento del espacio, el volumen y el peso.

A manera de cuarta conclusión, hemos establecido y acotado un marco teórico conceptual que hilvana dialécticamente la técnica de la latexgrafía con los discursos contemporáneos en torno al sentido de las imágenes, los cuerpos y las metáforas de la piel, que desde los posicionamientos filosóficos, sociológicos y antropológicos se tejen en las propuestas artísticas de nuestros referentes, quienes han sido meticulosamente escogidos por su vínculo con los conceptos que imperan en nuestra poética visual: las huellas del tiempo y los fragmentos de memoria. Mediante esta serie de imágenes hemos construido puentes entre nuestra investigación y los discursos expresivos del cuerpo, con un hilo conductor esencial, el resguardo de la integridad física y la permanencia de la impronta y el contacto, así como la conjunción de los diversos lenguajes que incorporan la gráfica desde sus necesidades discursivas y en función de los conceptos abordados, que van desde la poética de la materia, la mística del cuerpo propio o el activismo político y denuncia social.

Desde nuestra práctica, creemos que al desdoblar la imagen corpórea 
y transferir su huella, se expanden consigo las lecturas asociadas a determinados cánones que rigen la percepción y representación imaginaria del cuerpo, en tanto que unidad de sentido, en la sociedad occidental. En virtud de la experiencia y posibilidades técnicas que nos ofrece la latexgrafía, podemos aproximarnos a los fragmentos corporales dislocados de su unidad jerárquica y forma convencional. Es decir, la huella de la piel encarna la imagen corpórea. Una piel que hace de frontera biológica y sociocultural con el mundo, en cuya impronta se encriptan las marcas que definen la heterogénea condición humana, y la cual hemos reducido a residuos e indicios, para que su rastro quede esparcido y pueda volverse a reconfigurar de todas las formas posibles.

De esta manera, el cuerpo deviene en piel, ella representa la memoria gráfica que documentamos y archivamos en esta investigación. Así, la imagen corporal queda metonímicamente descompuesta en partes informes, abyectas y un tanto grotescas. Mudar de piel es un acto tan simbólico como biológico, que nos remite al renacer y la resiliencia, para dejar atrás viejos atributos que condicionan nuestra mirada y la experiencia corporal. Una dimensión estética que confronta directamente los cánones de belleza, que desde el imaginario hegemónico se dictan en nuestra cultura. A esta dimensión estética la denominamos como la bella extrañez, es decir, la posibilidad de mirar y sentir el cuerpo desde lo que es, o mejor dicho desde lo que somos: ese entrelazo que nos une fenomenológicamente a la carne del mundo, con sus perfectas imperfecciones, que son, al fin al cabo, los signos de nuestra identidad, la misma que se expone al otro, en la memoria de la piel.

Por último, nuestra quinta conclusión, recae en la conceptualización, ejecución y análisis del corpus de obra realizado en el marco de la presente investigación, a través de la escogencia de piezas diferenciales, que, por sus características, han significado puntos de inflexión en nuestro proceso creativo. Primeramente, nos gustaría poner de manifiesto que la realización de esta tesis doctoral ha surgido de la necesidad de ampliar y reformular nuestras propias ideas creativas en el marco del nuevo ámbito experimental, que decantó en la invención de la técnica de la 
latexgrafía, mediante la cual hemos imbricado las reflexiones teóricas y poéticas del cuerpo-piel. Así, integramos a nuestra gráfica componentes de la escultura, la instalación, el performance, y la docencia extendida en y desde la comunidad.

Desde la experiencia creadora, cada obra es el resultado de una intención artística con intereses particulares que marcan la pauta para abordar su complejo andamiaje metodológico. De manera, que en cada imagen hay siempre componentes y retos distintos, aunque se comprendan dentro de un mismo eje técnico. Este factor es muy importante, ya que implica que el pensamiento artístico reflexiona en función del problema, y no existe un camino predeterminado para construir la imagen, sino que son los estímulos, que vienen desde las cualidades de la materia y el las derivas del concepto, los que nos van guiando en el proceso, motivo por el cual hay obras que nunca estarán resueltas, sino que por su naturaleza están hechas para cambiar y ampliarse con el tiempo, como por ejemplo, Archivo digital e Indicios.

Otro factor a destacar es el hecho de que, desde nuestro punto de vista, contemplamos el estado de la gráfica actual de la misma manera en que leemos la corporalidad, es decir, como un conjunto de fragmentos que se han desarticulado de su unidad de sentido, para migrar de un lugar al otro, y transmitir un concepto, sensación o metáfora visual, que ayude a provocar una reflexión crítica en el espectador, para y conseguir que se conecte empáticamente con el universo ficcional que procuramos construir en nuestras instalaciones.

El proceso creativo no se limita a la creación de metáforas visuales y a la materialización de las imágenes, sino que se expande al diseño museográfico en donde estas se hilan entre sí para conducir al espectador en el espacio. Finalmente, y no menos importante, creemos que llegar a establecer una serie de conclusiones en el marco de una investigación artística, no implica compartir respuestas a nuestros problemas, ya que, desde nuestro enfoque, el arte es un campo generador de preguntas que apelan a la percepción establecida de las cosas, para re imaginar nuevas 
formas de acercarse a lo cotidiano, en nuestro caso, al cuerpo expuesto en su piel, y las memorias gráficas escritas en ella. Por consiguiente, cada obra es un fragmento significante de una realidad que ficcionamos para poder desdoblar su complejidad. No pretendemos resolver las problemáticas de la experiencia corporal ni escribir un manifiesto de gráfica contemporánea, sólo hemos pretendido abrir los límites del cuerpo y del grabado, para que sus fronteras se vuelvan porosas, elásticas, translúcidas, sensibles y receptivas al tiempo y al cambio, como la piel de la latexgrafía. 


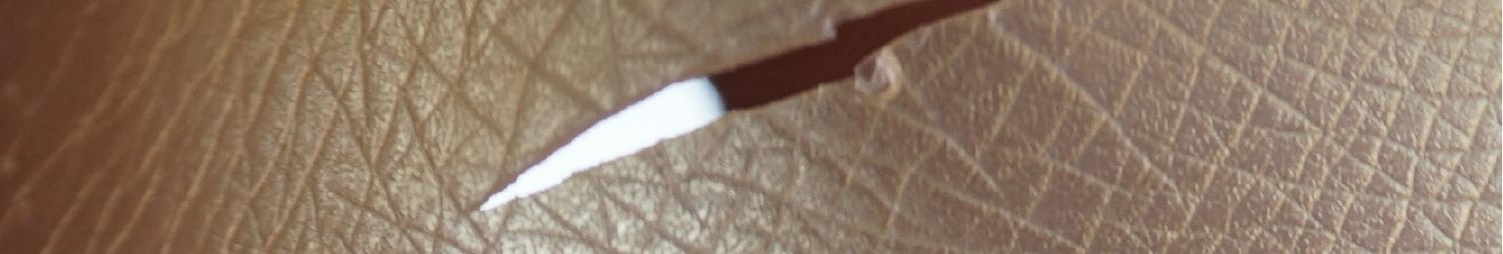

S.

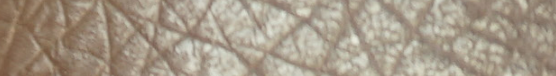

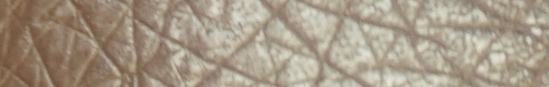

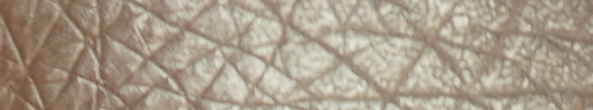

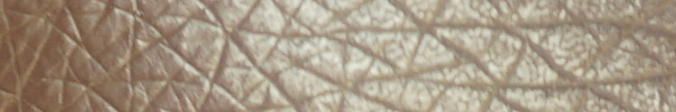

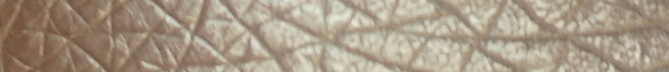

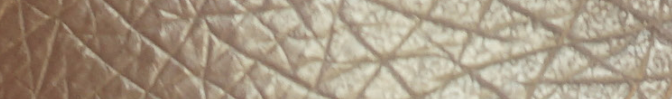

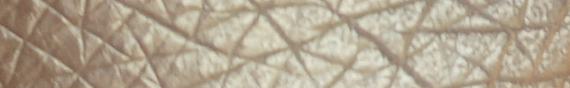

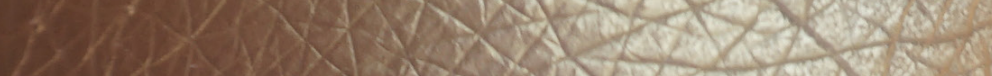

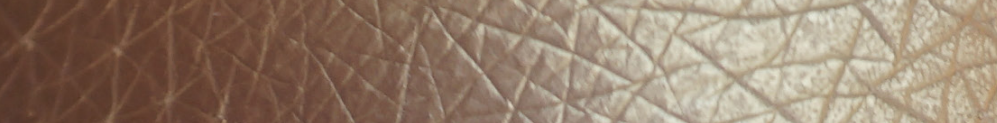

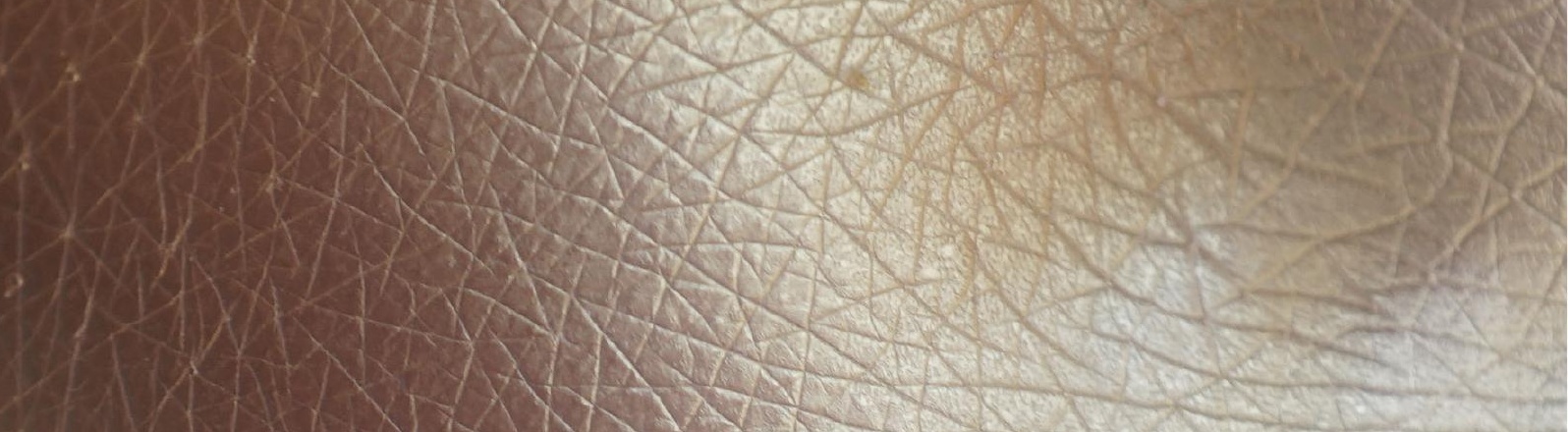

$2 \frac{2}{3} \times 13$

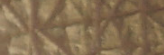

Ding

1.

$\sin ^{2}$

170 .

H.

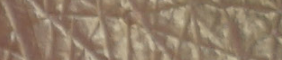

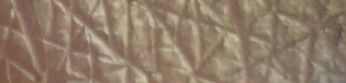

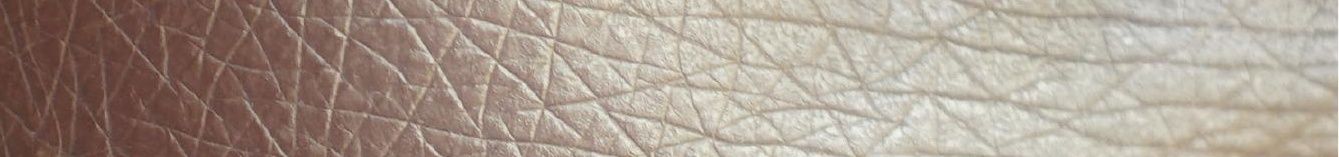

$7=(7+2 \pi$

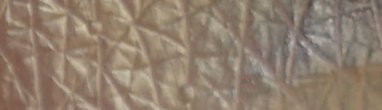

$x+17+2$

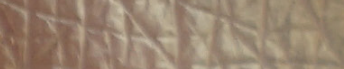

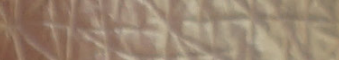

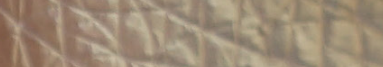

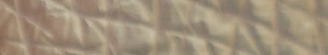

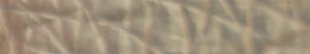

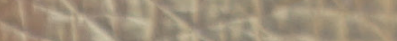




\section{FUENTES REFERENCIALES}

En este apartado hemos organizado alfabéticamente las fuentes referenciales que provienen de: Tesis doctorales, trabajos finales de máster, monografías, artículos académicos, catálogos, recursos audiovisuales y fílmicos, así como páginas web.

- Adorno, T. (1962). Prismas: la cultura a la crítica y la sociedad. Ediciones Ariel.

- Agamben, G. (2005). Lo que queda de Auschwitz. El archivo y el testiǵo. Homo Sacer III. Pre-textos.

- Agis, D. F.(2003). Una piel y mil metáforas: paradojas de la identidad. Boletín Millares Carlo, (22), 249-264. https://mdc.ulpgc.es/utils/ getfile/collection/bolmc/id/21/filename/22.pdf

- Almodovar, P. (Director). (2011). La piel que habito [Película]. El Deseo P. C.

- Amador, A. (2013). La piel como soporte estético del cuerpo. Análisis e interpretación de la piel y el cuerpo en la obra fotoǵráfica de Isabel Muñoz, Rodriǵo Petrella y Ricardo Marujo [Tesis de doctorado]. Repositorio Institucional-Universitat Politècnica de València. https:// riunet.upv.es/handle/10251/34508.

- Anna, A. (2013). Creación y pensamiento hacia un ser expandido. Reflexiones sobre los límites del yo en el arte contemporáneo. Editorial Trea.

- Anzieu, D. (2003). El yo-piel. Biblioteca Nueva.

- Appadurai, A. (2001). La modernidad desbordada. Dimensiones culturales de la ǵlobalización. Fondo de Cultura Económica de Argentina.

- Arendt, H. (2019). Eichmann en Jerusalén. Penguin Random House.

- Aula Deleuze. (23 de enero del 2020). Gabriela Berti: "El Plieǵue. Leibniz y El Barroco" De Gilles Deleuze. [Archivo de Video]. Youtube. https://wwwyoutube.com/watch?v=6brK1 Rg15no

- Ayala, R. A. (2005). Deleuze y los plieǵues del pensamiento: Leibniz 
y el Barroco. Pensamiento. Papeles de Filosofía, (04). 87-97. https:// revistacoatepec.uaemex.mx/index.php/pensfilosofia/article/view/259

- Brasero, J. (2017). Desarrollo de nuevas formulaciones de látex de caucho natural libres de n-nitrosaminas, hipoalergénicas y ecológicas, su caracterización por RMN de campo bajo. [Tesis de doctorado, Universidad Complutense de Madrid]. https:/eprints.ucm.es/id/ eprint/42693/

- $\quad$ Bal, M. (2016). Tiempos Trastornados. Análisis, histórias y políticas de la mirada. Akal.

- Bal, M. (2010). Of What One Cannot Speak. University of Chicago Press.

- $\quad$ Bataille, G. (1981). El culpable. Tauros

- $\quad$ Bataille, G. (1985). Visions of excess: Selected writings, 1927-1939. University of Minnesota Press.

- Baudrillard, J. (2016). El crimen perfecto. Anagrama.

- Bauman, Z. (2002). Modernidad Líquida. Fondo de Cultura de España.

- Belting, H. (2007). Antropología de la imaǵen. Katz Editores.

- Benjamin, W. (2005). El Libro de los Pasajes. Akal

- Benjamin, W. (2018). Iluminaciones. Tauros.

- Benthien, C. (2002). Skin: on the cultural border between self and the world. Columbia University Press.

- Borgdorff, H. (2012). The conflict of the faculties. Perspectives on artistic research and academia. Leiden University Press.

- Brea, J. L. (2016). Las tres eras de la imagen. Imagen-materia, film, e-image. Akal.

- Butler, J. (1990). El género en disputa. El feminismo y la subversión de la identidad. Barcelona: Paidós.

- Bruguera, T. (20 de marzo del 2021). Tania Bruguera. http://www. taniabruguera.com/cms/

- Barrera,J.M.(2018). El cuerpo como nueva superficie de inscripción de la política: Michel Foucault yla biopolítica. Sociologíay tecnociencia: Revista digital de sociología del sistema tecnocientífico, 8(1), 27-42. https://dialnet.unirioja.es/servlet/articulo?codigo=6275473

- Bernal Pérez, M.d.M. (2016). Los nuevos territorios de la ǵráfica: 
imaǵen, proceso y distribución. Arte, Individuo y Sociedad, 28 (1), 71-90. http://hdl.handle.net/11441/49851

- Bois, Y.,Hollier, D., Krauss, R., \& Damisch,H.(1998). A Conversation with Hubert Damisch. October, 85, 3-17. doi:10.2307/779179

- Bulo Vargas, V. (2009). Cuerpo y diferencia en Gilles Deleuze. Daimon: revista de filosofía, (48), 55-63. https:/digitum.um.es/ digitum/handle/10201/26616

- Cadavid, L. E. G. (2006). El ser-corporal-en-el-mundo como punto de partida en la fenomenología de la existencia corpórea. Pensamiento Educativo, Revista de Investigación Latinoamericana (PEL), 38 (1), 46-61. http://revistaaisthesis.uc.cl/index.php/pel/article/view/24005

- Calvo, J. (15 de enero 2021). Javier Calvo. https://www. javiercalvosandi.com/

- Camnitzer, L. (1969). Texto. En Camnitzer, L., Castillo, J., y Porter, L. (1969) En The New York Graphic Workshop. Museo de Bellas Artes de Caracas. https://icaa.mfah.org/s/ es/item/1241878\#? c=\&m=\&s=\&cv=1\&xywh=-60\%2C 302\%2C3082\%2C1725

- Camnitzer, L. (2004) "El New York Graphic Workshop." Revista del Instituto de Cultura Puertorriqueña (San Juan) 5, no.10. https:// icaa.mfah.org/s/en/item $/ 785884 \#$ ? $c=\& m=\& \mathrm{~s}=\& \mathrm{cv}=\& \mathrm{xywh}=$ 719\%2C737\%2C3791\%2C2121

- Candiani, A. (2018). "Encuentro con otras disciplinas. Acerca de la no-especificidad de las prácticas ǵráficas contemporáneas”, en Encuentro IMPACT 10, 46-55.

- Casanova, E. (Director). (2017). Pieles [Película]. Pokeepsie FilmsNadie es Perfecto.

- Castro Muñiz, J.A. (2007). Mapas invisibles para una ǵráfica electrónica: de la huella incisa al ǵrabado con luz. Dx5, Digital \& Graphic Art Research.

- Castro Muñiz, J.A. (Ed.) (2011). On Minded Prints. Gráfica Contemporánea de campo expandido. Grupo de investigación Dx5 Universidad de Vigo. Gráficas Anduriña.

- Castro Muñiz, J.A. (Ed.) (2012). Encuentros de interacción gráfica. Originalidad en la cultura de la copia. Editorial Grupo de investigación 
Dx5 - Universidad de Vigo.

- Censi, W. (2016). Baudrillard y el cuerpo. Metamorfósis, metafísica y simulación. USAM.

- Chavarría, M. J. (com.) (2012). Bitácora de oficios. Sila Chanto. (Exposición celebrada en el Museo de Arte y Diseño Costarricense del 17 de mayo al 7 de julio del 2012). MADC.

- Chavarría, M. J. y Hernández, E., (comisarios) (2010). Mudar la piel. Karla Solano. (Exposición llevada a cabo en el Museo de Arte y Diseño Costarricense del 30 de septiembre al 13 de noviembre del 2011). MADC.

- Chavarría, M. J., López, B. V., Y Villena, S. (comisarios) (2013). Dis-local. Exposición de Javier Calvo. ( Exposición llevada a cabo en el Museo de Arte y Diseño Costarricense del 25 de abril al 29 de juniodel 2013) MADC.

- Chaves Badilla, S. (2011). Propuesta técnica y didáctica de huecograbado en cuero como materia prima para la elaboración de matrices en técnicas de grabado no tóxico para la Facultad de Bellas Artes de la Universidad de Costa Rica. [Tesis de doctorado, Universidad Complutense de Madrid].

- Chojnacka, B y Gizinski, K (comisarios) et al (2019). Embodied Memory. Exhibition of works by Priscilla Romero. Laurate of MTG Krakow 2018, del 7 de noviembre del 2019 al 19 de enero del 2020). $\mathrm{MOB}$

- Chojnacka, B.(2019). "Concept in process, an exhibition in progress", en Chojnacka, B y Gizinski, K (comisarios) et al (2019). Embodied Memory. Exhibition of works by Priscilla Romero. Laurate of MTG Krakow 2018. MOB, Pp. 15-17

- Círculo de Bellas Artes. (12 de marzo del 2018). Georges DidiHuberman: Medalla de Oro del CBA + conferencia "Planto, pregunta, sublevación". [Archivo de video]. Youtube. https:/wwwyoutube.com/ watch?v=fQzie3P_MKM

- Círculo de Bellas Artes. (25 de mayo del 2015). Hans Belting: rostro y máscara en el espejo de la Historia. [Archivo de video]. Youtube. https://wwwyoutube.com/watch?v=UK2jOvdC0T8.

- Colombres, A. (2004). Teoría transcultural del arte: hacia un 
pensamiento visual independiente: ensayo. Ediciones del Sol.

- Colón, J.M. (director). (2015). Hombre neǵro, piel blanca. [documental]. Alquimistas Producciones Audiovisuales.

- Cormier, D. (2008). Rhizomatic Education: Community as Curriculum. Innovate: Journal of Online Education , 4 (5). https:// www.learntechlib.org/p/104239/

- Cunillera, M. (2007). Negarse a mirar: lo abyecto. En Fernández Polanco, A. (Ed.), (2007). Cuerpo y mirada, huella del siglo XX (pp. 123-143). Museo Nacional Centro de Arte Reina Sofía.

- $\quad$ Deleuze, G. (1989). El plieǵue. Leibniz o el barroco. Paidós.

- Deleuze, G. y Guatari, F. (2010). Mil mesetas. Capitalismo y Esquizofrenia. Pre-textos.

- Didi-Huberman, G. (2014). Cortezas. Shangrila.

- Didi-Huberman, G. (2015). Ante el tiempo. Historia del arte y anacronismo de las imagenes Adriana Hidalgo Editora.

- Didi-Huberman, G. (2017). Imágenes pese a todo. Memoria visual del holocausto. Paidos.

- Didi-Huberman, G. (2018). Cuando las imágenes tocan lo real. Círculo de Bellas Artes.

- Dyrda,Z.(13 de abril de1 2021).Zuzanna Dyrda. http://zuzannadyrda. weebly.com/

- Dyrda, Z. (2017). Interference into the Object. Transóressive Print. [Tesis de doctorado]. Repositorio Institucional-The Eugeniusz Geppert Academy of Art and Desing.

- Espacio Fundación Telefónica Madrid. (7 de febrero del 2020). Gilles Lipovedsky. Sobre la ligereza. [Archivo de video]. Youtube. https://www.youtube.com/watch?v=73i7cylPmqo.

- Evangelio, F. (2019). "Embodied memory, a trace expressing the truth of Priscilla Romero”, en Chojnacka, B y Gizinski, K (comisarios) et al (2019). Embodied Memory. Exhibition of works by Priscilla Romero. Laurate of MTG Krakow 2018. MOB, Pp. 66-72

- Fajardo-Hill, C., Y Giunta, A. (comisarias) (2017). Radical Women: Latin America Art, 1960-1985. (Exposicion llevada a cabo en el Hammer Museum, University of California del 13 de abril al 22 de julio 2017). Prestel. 
- Faucault, M. (1999). Viǵilar y castiǵar. Nacimiento de la prisión. Siglo XXI.

- Filipovic, E. y Mytkowska, J. (comisarias) (2012). Alina Szapocznikow. Sculpture Undone, 1955-1972. The Museum of Modern Art del 7 de octubre del 2012 al 28 de enero del 2013). MOMA.

- Frank1, V. (2019). El hombre en busca de sentido. Herder.

- FVCB. (15 de febrero del 2021). La Fundación Vera Chaves Barcellos. http://www.fvcb.com/

- Galindo, R. (20 de abril del 2021). Regína José Galindo. http://www. reginajosegalindo.com/

- Gallardo, V. (2015). La estampa que habita el espacio. Arte múltiple e instalación. Recorriendo los límites de la gráfica contemporánea. [Tesis de doctorado]. Repositorio Institucional-Universitat Politècnica de València. https://riunet.upves/handle/10251/52026

- García, T. A. (2013). Cuerpos sin límites. Transgresiones carnales en el arte. Casemiro.

- Garramuño, F. (2015). Mundos en común: ensayos sobre la no especificidad del arte. Fondo de Cultura Económica de Argentina.

- González Alberdi, M. (2008). Washi: el papel japonés, genésis y supervivencia. Imafronte, (16). https://revistas.um.es/imafronte/ article/view/37441

- Gonzalo, I. M. (2001). Cartoǵrafías liminales: el (des) plieǵue topológíco de la práctica identitaria. Política y sociedad, (36), 205222. https://dialnet.unirioja.es/servlet/articulo?codigo $=154616$

- Guasch, A. (2005). Los luǵares de la memoria: El arte de archivar y recordar. Matèria. Revista internacional d'Art, O(5), 157-183. https:// revistes.ub.edu/index.php/materia/article/view/11382/14168

- Guasch,A.M.(2000). El arte último del siǵlo XX. Del posminimalismo a lo muticultural. Alianza Forma.

- Guasch, A. M. (2014). La memoria del otro en la era de lo ǵlobal. Revista de estudios globales y arte contemporáneo, 2(1), 81-91. DOI: https://doi.org/10.1344/regac2014.1.06

- Guasch, A. M. (2016). El arte en la era de lo ǵlobal 1989-2015. Alianza Forma. 
- Han, B. C. (2020). La desaparición de los rituales. Herder.

- Haraway, D. (1991). Simians, Cyborós, and Women: The Reinvention of Nature. New York: Routledge.

- Hernández Villalobos, E. y Arguedas, A. (2019). Tinta y papel: el ǵrabado en Costa Rica 1934-2000. Una aproximación históricoestética. EUNA

- Hernández-Navarro, M.A. (2015). Materializar el pasado. El artista como historiador (benjaminiano). Micromegas.

- Hernández-Navarro, M.A. y Cruz, P. (Ed.). (2017). Cartografías del cuerpo: la dimensión corporal en el arte contemporáneo. Cendeac.

- Hernández, F. (2006). Campos, temas y metodologías para la investigación relacionada con las artes. En Hernández, F., Pérez López, H. J., y Gómez Muntané, M. C. (2006). Bases para un debate sobre investigación artística, (pp. 9-49). Ministerio de Educación y Ciencia.

- Hernández, F. H. (2008). La investigación basada en las artes. Propuestas para repensar la investigación en educación. Educatio siglo XXI, 26, 85-118. http://hdl.handle.net/10201/26832

- Husser1, E. (1997). Ideas relativas a una fenomenología pura y una filosofía fenomenológica. Libro segundo: Investigaciones fenomenológicas sobre la constitución. Fondo de Cultura Económica.

- IMPACT 10, (2018). Encuentro y Conferencia Internacional Multidiciplinar de Gráfica. (Celebrado en Santander del 1 al 9 de setiembre del 2018). SM Pro Art Circle

- Jablonski, N. G. (2013). Skin: a natural history. University of California Press.

- Jiménez, C. (comisario). (2008). Oscar Muñoz. Documentos de la Amnesia. (Museo Extremeño e Iberoamericano de Arte Contemporáneo. Exposición del 1 de octubre al 30 de noviembre de 2008). MEIAC.

- Kannan, H. (2011). Impressões, acúmulos e rasǵos: procedimentos litoǵráficos e seus desvios. [Tesis Doctoral-Universidade Federal do Rio Grande do Sul Instituto de Arte]. http://hdl.handle.net/10183/28920

- Kisteva, J. (2006). Poderes de la perversión. Ensayo sobre LouisFerdinand Cèline, Siglo XXI. 
- Krauss, R. (1979). La escultura en el campo expandido. En Foster, H. (2008). (Ed.), La Posmodernidad. (pp. 59-74). Kairós.

- Lacan, J. (1990). El estadio del espejo como formador de la función del yo (je) tal como se nos revela en la experiencia psicoanalítica, 8693. En Lacan, J. (1990). Escritos 1. Siglo XXI.

- Lachner, M. P. M., y López, M. A. (Eds.). (2019). Virǵinia PérezRatton: Centroamérica: deseo de luǵar. Museo Universitario Arte Contemporáneo-UNAM.

- Lanzmann, C. (director). (1985). Shoah [documental]. Les Films Aleph, Historia, Ministère de la Culture de la Republique Française

- Le Breton, D. (2002). Antropología del cuerpo y modernidad. Nueva Visión.

- Le Breton, D. (2007). Adios al cuerpo. La teoría del cuerpo en el extremo contemporáneo. La cifra editorial.

- Le Breton, D. (2017). El cuerpo herido. Identidades estalladas contemporáneas. Topía.

- Le Breton, D. (2018). La sociología del cuerpo. Siruela.

- Le Breton, D. (2019). Desaparecer de sí: una tentación contemporánea. Siruela.

- Levi, P. (2018). Triloǵía de Auschwitz. Barcelona: Ediciones Península.

- Lipovetsky, G. (2016). De la liǵereza. Anagrama.

- López, S. (comisario). (2005). Las horas : Artes visuales de América Latina contemporánea. (Exposición en IMMA - Irish Museum of Modern Art, Dublín del Zurich del 5 de octubre del 2005 al 15 de enero del 2006) Daros-Latinamerica AG.

- Los dependientes. (2 de julio del 2013). Gilles Deleuze - ¿Qué es el acto de creación?. Conferencia impartida en La Fémis, Escuela Superior de Oficios de Imagen y Sonido, París, 1987. [Archivo de video]. Youtube. https://wwwyoutube.com/watch?v=dXOzcexu7Ks.

- Lupton, E. (2002). Skin: Surface, Substance and Desiǵn. Princeton Architectural Press.

- Mandel, C. (2013). Notas sobre la categoría de lo abyecto en las artes visuales contemporáneas. ESCENA. Revista de las artes, 72(1), 8-12. https://revistas.ucr.ac.cr/index.php/escena/article/view/14450 
- Marchan Fiz, S. (1986). Del arte objetual al arte de concepto (19601974). Epílogo sobre la sensibilidad posmoderna. Akal.

- Martínez García, ÓJ. (2006). El uso de la piel animal como soporte para obra gráfica original [Tesis doctoral no publicada]. Universitat Politècnica de València. https://m.riunet.upv.es/ handle/10251/1967?show=full

- Martínez Moro, J. (2008). Un ensayo sobre ǵrabado: (a principios del siǵlo XXI). Universidad Nacional Autónoma de México.

- Martínez Moro, J. (2018). "Encuentro con el tiempo. Grabado en expansión: espacio y tiempo”. Encuentro IMPACT 10, 26-35

- Martínez Rossi, S. (2008). La piel como superficie simbólica. Procesos de transculturación en el arte contemporáneo. [Tesis Doctoral-Universidad de Granada] http://hdl.handle.net/10481/2040.

- Mcevilley, T. (2007). De la ruptura del cul de sac. Arte en la segunda mitad del siǵlo XX. Akal.

- Mendieta, A. (1987). Ana Mendieta: A Retrospective. (Exposition, New York, New Museum of Contemporary Art, 20 Novembre 198724 Janvier 1988) New Museum of contemporary art.

- Merleau-Ponty, M. (1999). Fenomenología de la percepción. Altaya

- Merleau-Ponty, M. (2010). Lo visible y lo invisible. Nueva visión.

- Mínguez-García, H. (2012). La ǵráfica múltiple en la cultura de la copia. Una aproximación fenomenológica. En Castro Muñiz, J.A. (Ed.) (2012). Encuentros de interacción gráfica. Originalidad en la cultura de la copia (pp-69-86). Editorial Grupo de investigación Dx5 - Universidad de Vigo.

- Minguez García, H. (2013). Gráfica Contemporánea. Del elogio a la materia a la ǵráfica intanǵible. Universidad Autónoma de Ciudad Juárez.

- Mínguez García, H. (2013). Copia versus original-múltiple. Una relación dialógica en el arte ǵráfico reproducible. Arte, Individuo y Sociedad, 25(1), 77-93. https://www.redalyc.org/ pdf/5135/513551284006.pdf

- Mínguez García, H. (2014). La generación de conocimiento en la creación artística y su orientación en el ámbito universitario a nivel de posǵrado. Revista Sonda: Investigación y Docencia en Artes y Letras, 
(3), 23-36.https://dialnet.unirioja.es/servlet/articulo?codigo=6653207

- Mínguez García, H. (2016). La metaforicidad y la copia en el arte múltiple. ASRI: Arte y sociedad. Revista de investigación, (11), 15. https://dialnet.unirioja.es/servlet/articulo?codigo=7279244

- Mosquera, G. (2001). Adiós identidad, arte y cultura desde América Latina: I y II Foros Latinoamericanos. Junta de Extremadura, Consejería de Cultura.

- Mosquera, G. (2010). Caminar con el diablo: textos sobre arte, internacionalismo y culturas. Exit.

- Museo Nacional Centro de Arte Reina Sofía. (3 de febrero del2014). ¿Qué es la antropología de la imagen?. Entrevista con Hans Belting . [Archivo de video]. Youtube. https:/www.youtube.com/ watch?v=j8090TYBtDw.

- MuseoMAPR. (16 de febrero del 2021). Encuentro de artistas Liliana porter y Charles Juhasz, dirigido por Alicia Candiani. [archivo de video]. Youtube. https://www.youtube.com/watch?v=pvjng-jqlso.

- MuseoMAPR. (16 de febrero del 2021). Memoria, identidad y desplazamiento. Primer encuentro de artistas junto a Erika Diettes (Colombia), Víctor Vázquez (Puerto Rico), dirigido por la artista y curadora argentina Alicia Candiani. [Archivo de video]. Youtube. https://www.youtube.com/watch?v=BuJCMPd7P_U.

- Nancy, J. L. (2007). Ser singular plural. Arena.

- Nancy, J. L. (2014). El arte hoy. Prometeo Libros.

- Nancy, J. L. (2016). Corpus. Arena.

- National Gallery of Art. (2 de mayo del 2021). The 70th A. W. Mellon LecturesintheFineArts:Contact:ArtandthePullofPrint,Part2:Reversal. Lecture of Jennifer L. Roberts, Harvard University. [Archivo de video]. https://www.nga.gov/research/casva/meetings/mellon-lectures-inthe-fine-arts/roberts-2021.html?fbclid=IwAR2IADzeuRmmIhgPc_ a63yv7xjuvpXcs3YtCNtvXU4CEgtN7ugqGc6cKd-A.

- National Gallery of Art. (25 de abril del 2021). The 70th A. W. Mellon Lectures in the Fine Arts: Contact: Art and the Pull of Print, Part 1: Pressure. Lecture of Jennifer L. Roberts, Harvard University. [Archivo de video]. https://www. nga.gov/research/casva/meetings/mellon-lectures-in-the-fine- 
arts/roberts-2021.html?fbclid=IwAR2IADzeuRmmIhgPc_ a63yv7xjuvpXcs3YtCNtvXU4CEgtN7ugqGc6cKd-A.

- Navarro, G. (2002). El cuerpo y la mirada: desvelando a Bataille. Anthropos.

- $\quad$ Nora, P. (2008). Lugares de la memoria. Trilce.

- $\quad$ Noyce, R. (2010). Critical Mass: Printmaking Beyond the Edǵe. A\&C Black.

- Noyce, R. (2013). Printmaking. Off The Beaten Track. Bloomsbury.

- Noyce, R. y Dyrda, Z. (2017). Interference into the object. Transgressive Print. Arworks of Zuzanna Dyrda. ( Exposición llevada a cabo en The Eugeniusz Geppert Academy of Art and Desing in Wroclaw) Drukarnia System-Graf.

- Oncina, F., y Cantarino, M. E.(Eds). (2011). Estética de la memoria. Universitat de València.

- Pallasmaa, J. (2012). La mano que piensa. Sabiduría existencial y corporal en la arquitectura. Gustavo Gili.

- Pallasmaa, J. (2014). La imaǵen corpórea. Imaǵinación e imaginario en la arquitectura. Gustavo Gili.

- Pallasmaa, J. (2017). Los ojos de la piel. Gustavo Gili.

- Pallasmaa, J. (2018). Esencias. Gustavo Gili.

- Pelzer-Montada, R. (2018). El grabado en el arte contemporáneo; el grabado como arte contemporáneo, Encuentro IMPACT 10, pp. 518-521

- Pelzer-Montada, R. (2019). "A model of Intactness- Priscilla Romero 's work on occasion of her exhibition "Embodied Memory" at the Leon Wyczlkoski District Museum in Bydgoszcz", en Chojnacka, B y Gizinski, K (comisarios) et al (2019). Embodied Memory. Exhibition of works by Priscilla Romero. Laurate of MTG Krakow 2018. MOB, Pp. 87-95

- Pelzer-Montada, R. (Ed). (2018). Prespectives on contemporary printmaking. Critical writing since 1986. Manchester University Press.

- Perez, D. (Ed.) (2004). La certeza vulnerable. Cuerpo y fotografía en el siglo XXI. Gustavo Gili.

- Prósperi, G. (2012). La cuestión del cuerpo en las filosofías de 
A. Kojève, G. Bataille, G. Deleuze y G. Agamben. [Tesis DoctoralUniversidad Nacional de La Plata]. http://www.memoria.fahce.unlp. edu.ar/tesis/te.809/te.809.pdf

- Raczek-Karcz, M. (dir.) et al (2018). Immersed in imaǵes. International Print Triennial 2018 Krakow. (Exposición celebrada en Bunkier Stuki Gallery of Contemporary Art, del 6 de julio al 26 de agosto de 2018). IMTG

- Raczek-Karcz, M. (ed), (2019). Inmersion-Marking-Interpolations. Series of exhibitions laurates in the center of attention 2019, SMTG. International Print Triennial Society in Kraków.

- Raczek-Karcz, M.A. (2019). "Embodied traces of memory", en Chojnacka, B y Gizinski, K (comisarios) et al (2019). Embodied Memory. Exhibition of works by Priscilla Romero. Laurate of MTG Krakow 2018. MOB, Pp. 37-42

- Ramírez, M. T. (2013). La filosofía del quiasmo: introducción al pensamiento de Maurice Merleau-Ponty. Fondo de Cultura Económica.

- Ramírez, M. T. (2017). El cuerpo por sí mismo. De la fenomenología del cuerpo a la ontología del ser corporal. Revista de filosofía open insight, 8(14), 49-68. http://www.scielo.org.mx/scielo.php?script=sci_ arttext\&\%20pid=S2007-24062017000200049

- Resnais, A. (director) (1955). Noche y Niebla [documental]. Cocinor, Cosmo-Films, Argos Films.

- Richir, M. (2016). El cuerpo. Segúuido de "la verdad de la apariencia". Brumaria.

- Roca, J. (ed) (2010). The Graphic Unconscious. (Catálogo de la Exposición Philagrafika 2010: The Graphic Unconscious, Philadelphia del 29 de enero al 11 de abril del 2010). Westcan Printing Company.

- Romero Cubero, P. (2010). en Cartografías del Imago. Latexǵrafía: proceso inédito de experimentación y aportación a la poética del cuerpo. [Trabajo Final de Máster-Universitat Politècnica de València].

- Ruiz Ruiz, M. (2008). El molde de bloque como matriz. Una mirada personal al relieve en la gráfica contemporáneo. [Tesis Doctoral-Universitat Politècnica de València]. https://riunet.upves/ 
handle/10251/3785

- Schaeffer,J. M.(2012). Arte, objetos, ficción, cuerpo. Cuatro ensayos sobre estética. Biblos.

- Solano, K. (20 de mayo del 2021). Karla Solano https://karlasolano. $\mathrm{com} /$

- Sullivan, G. (2004). Art Practice as Research Inquiry the Visual Arts. Teachers College, Columbia University.

- Tala, A. (2009). Printmakinǵ Handbook. Instalations \&̊ Experimental Printmakinǵ. A\& C Black.

- TV-UNAM. (14 de abril del 2018). Pensadores Contemporáneos: Georǵe Didi-Huberman. [Archivo de video]. Youtube. https://www. youtube.com/watch?v=m4hLqgrxXdg.

- UAMVIDEOS. (3 de noviembre del 2017). David Le Breton. Antropología del cuerpo en los mundos contemporáneos. [Archivo de video]. Youtube. https://www.youtube.com/watch?v=tOzkpaINTaA.

- Vargas, V. B. (2019). Desde el cuerpo a la materialidad. Contribuciones de Jean-Luc Nancy. Revista de Filosofía, 76, 29-37. https://actascoloquiogiannini.uchile.cl/index.php/RDF/search

- Xolocotzi, A. y Gibu, R. (Eds.) (2014). Fenomenología del cuerpo y hermenéutica de la corporeidad. Plaza y Vades. 


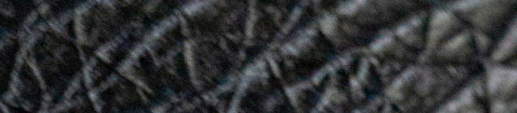

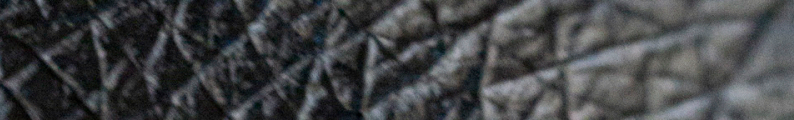

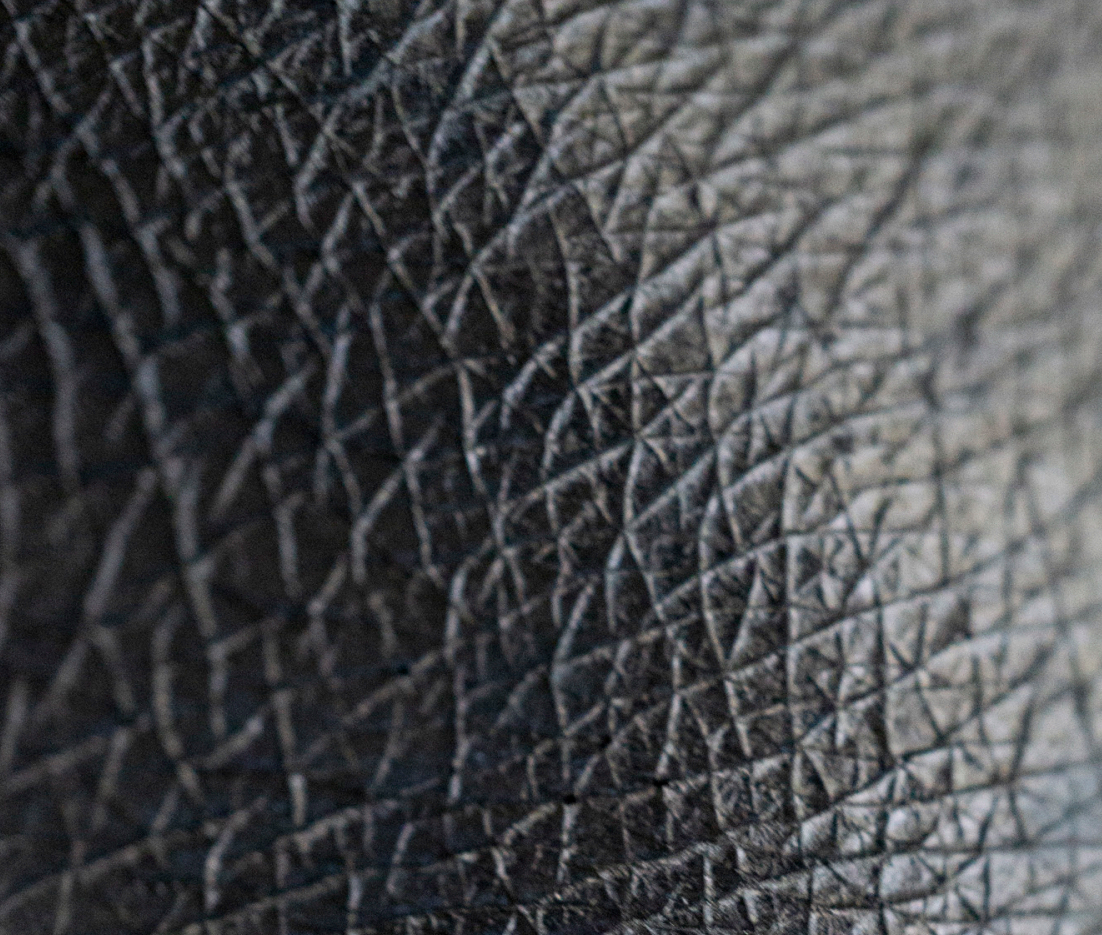

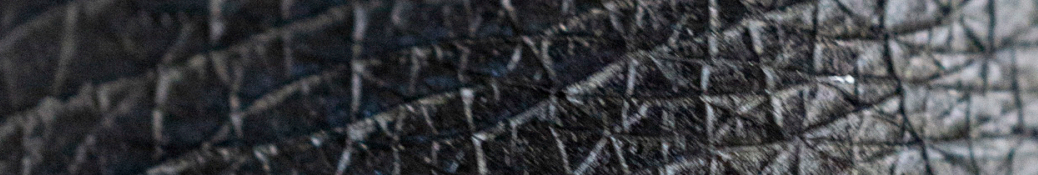

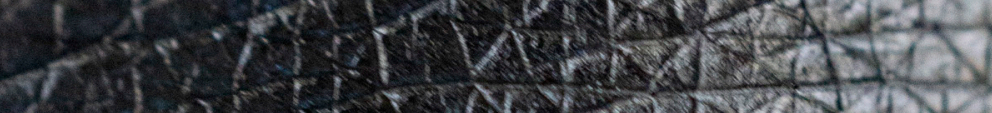

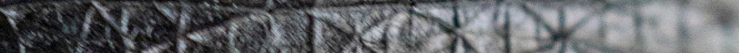

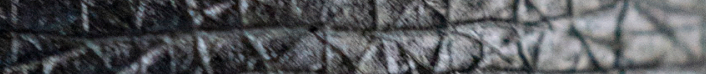

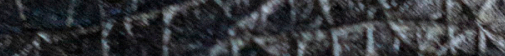

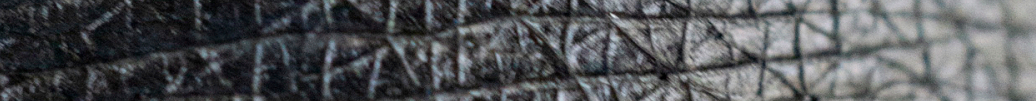

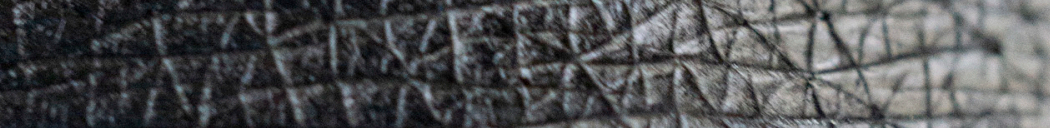

3 k.

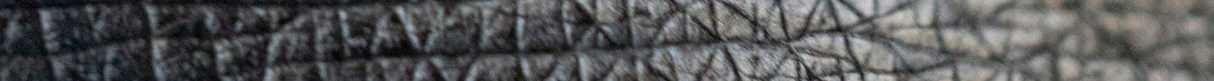

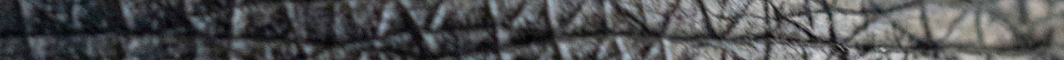

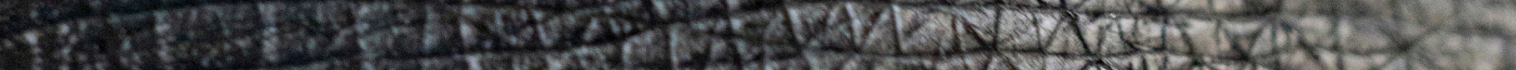

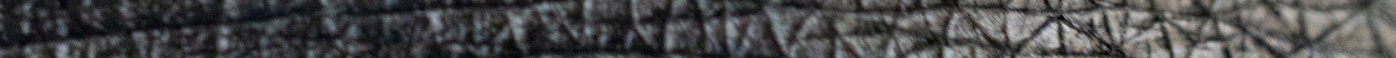

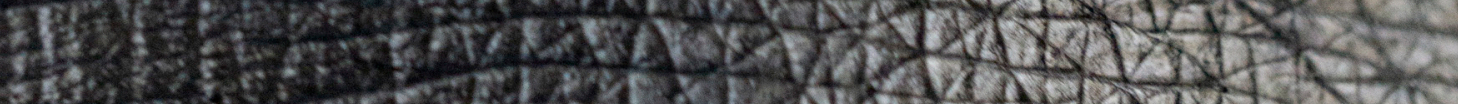

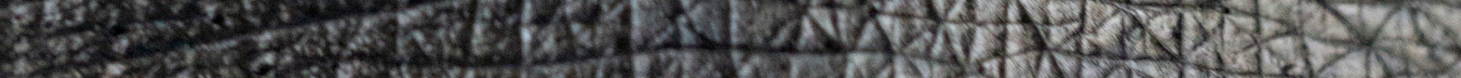

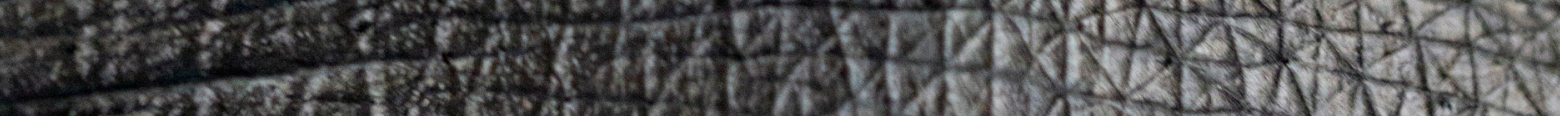

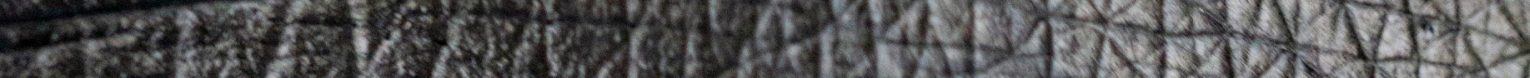

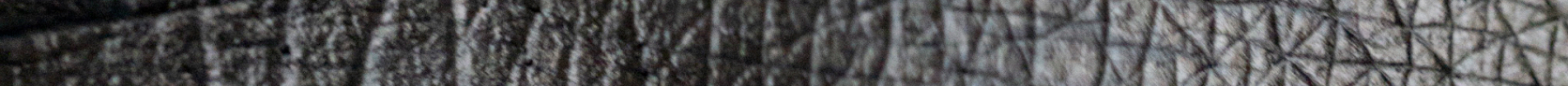
Z.

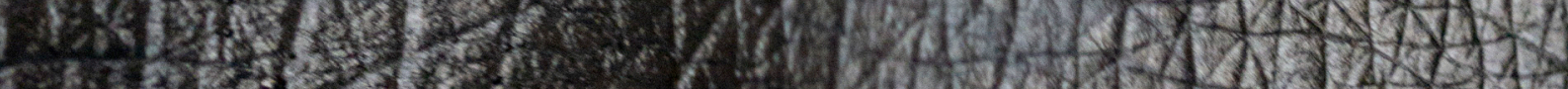

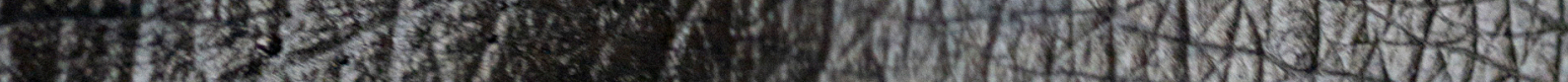

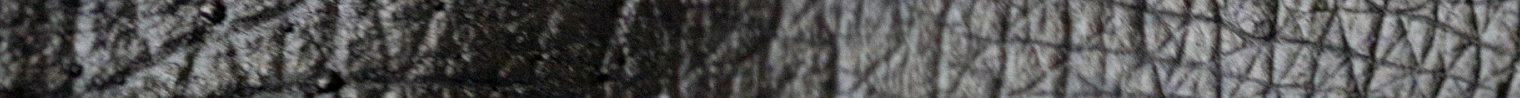
(26) 